\title{
The Constitution of the Environmental Emergency
}

\author{
Jocelyn Stacey \\ Faculty of Law, McGill University, Montreal \\ March, 2016
}

A thesis submitted to McGill University in partial fulfillment of the requirements of the degree of Doctorate of Civil Laws.

(C) Jocelyn Stacey, 2016 


\section{Table of Contents}

TABLE OF CONTENTS ................................................................................................... I

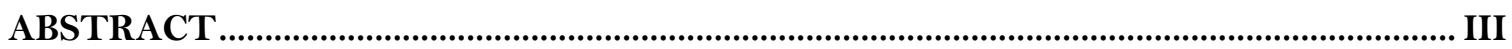

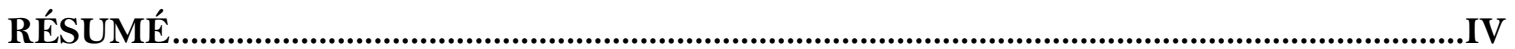

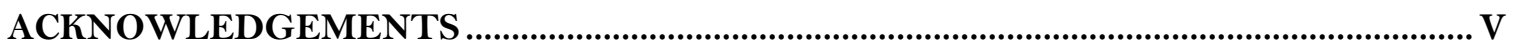

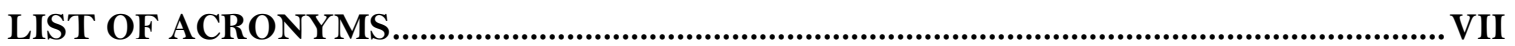

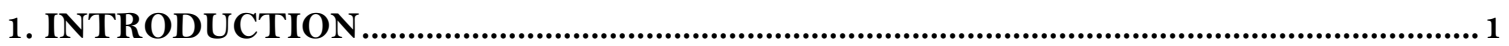

2. THE ENVIRONMENTAL EMERGENCY AND THE PROBLEM FOR THE RULE OF

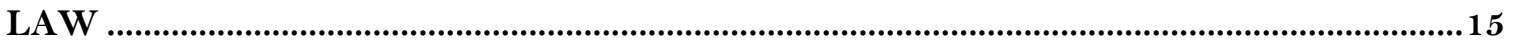

INTRODUCTION

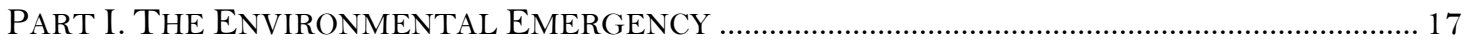

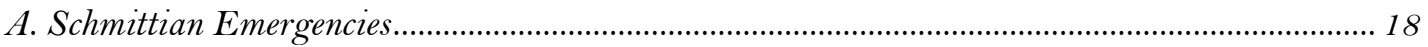

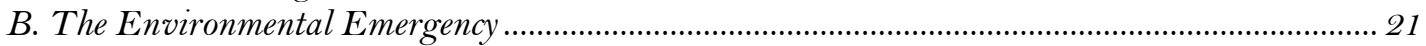

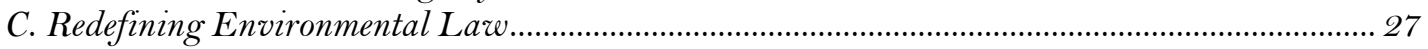

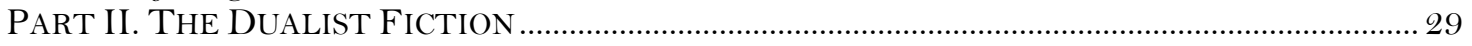

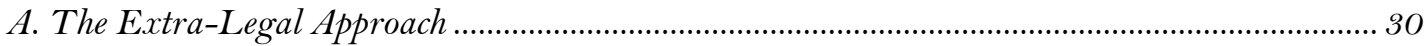

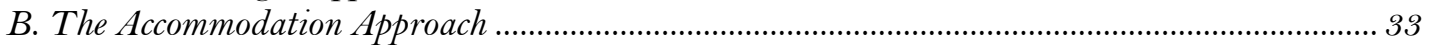

Part III. The Exceptional Emergency and the Pervasive Problem of Discretion

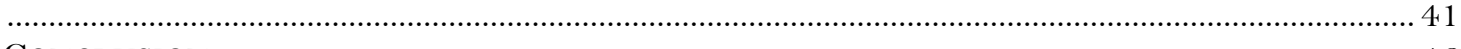

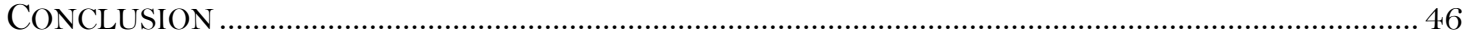

\section{ENVIRONMENTAL REFORM: THE PROBLEM OF DISCRETION IN}

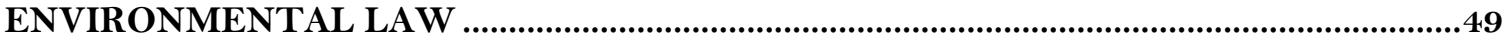

INTRODUCTION

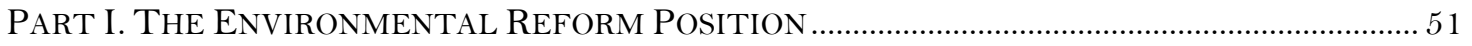

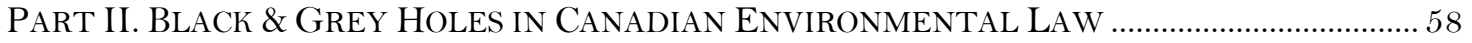

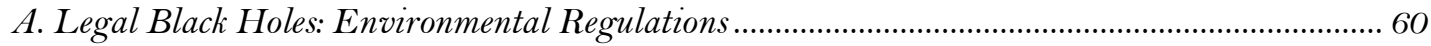

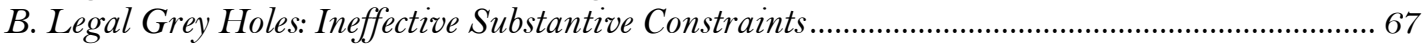

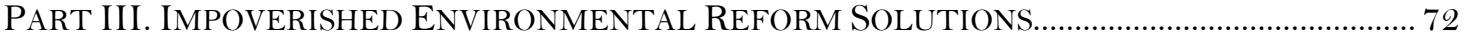

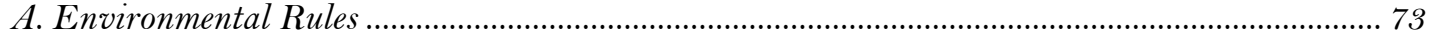

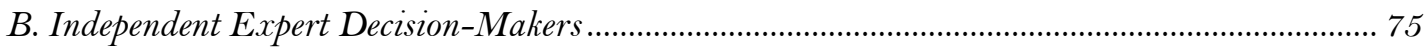

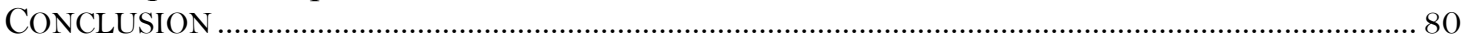

4. ENVIRONMENTAL GOVERNANCE: THE PROBLEM OF LAW IN

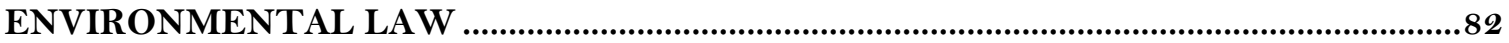

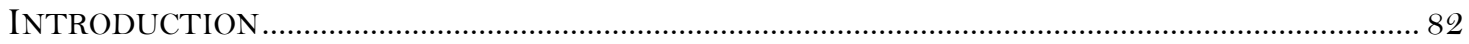

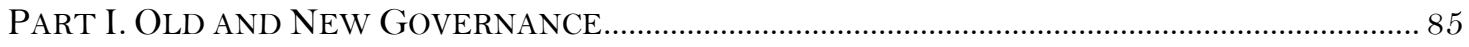

A. Responding to the Environmental Emergency and Rejecting the Formal Conception .................. 86

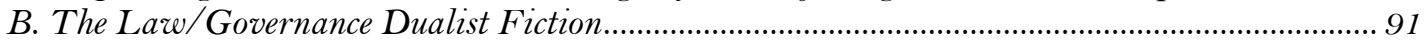

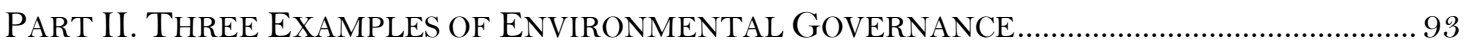

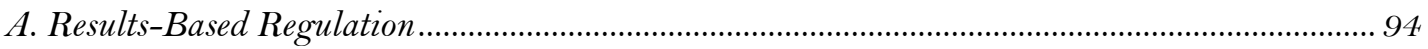

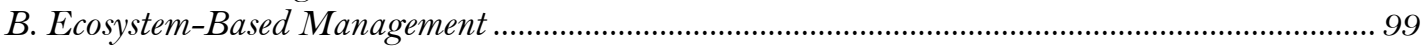

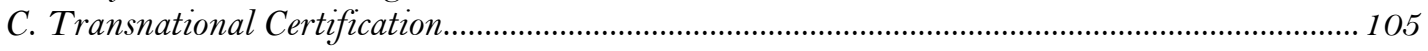

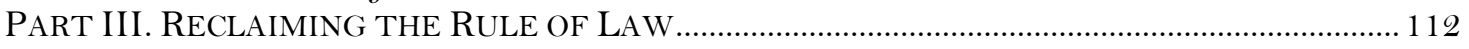

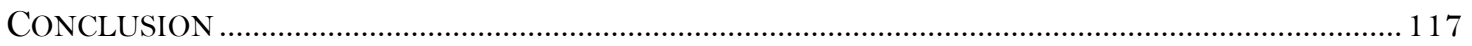




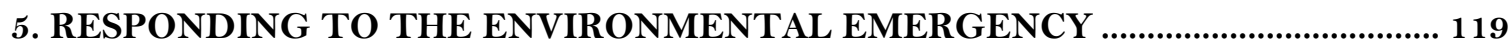

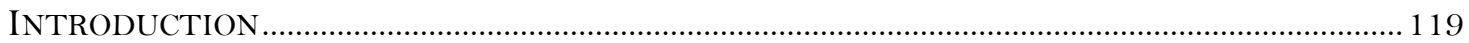

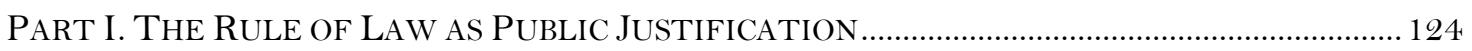

A. Public Justification in Canadian Administrative Law............................................................. 125

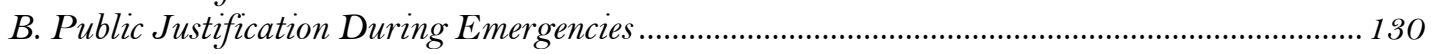

C. Implications for the Environmental Emergency ………......................................................... 135

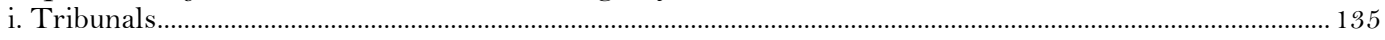

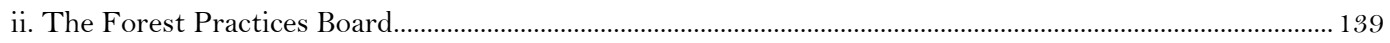

PART II. DELIBERATIVE DEMOCRACY, EXPERIMENTALISM, \& InSTITUTIONAL DESIGN ... 146

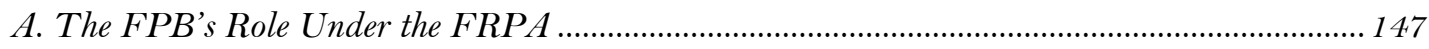

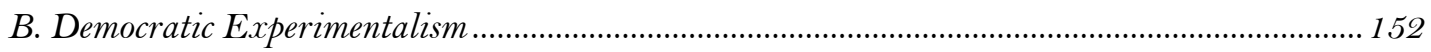

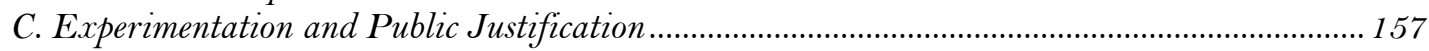

i. Constitutive Law (public delegation of authority) ……………………………………………………………158

ii. Substantive Law (justification discloses a defensible interpretation of the public interest) ........................ 160

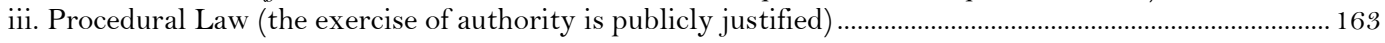

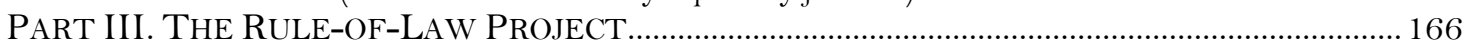

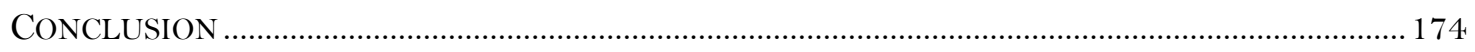

6. PUBLICLY JUSTIFYING CANADIAN PIPELINE DEVELOPMENT ......................... 176

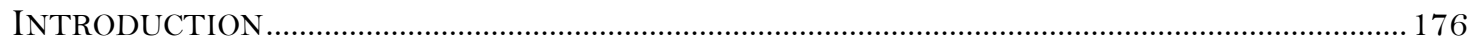

PART I. The PiPELINES, THE NEB AND TheIR PROBLEMS........................................................ 178

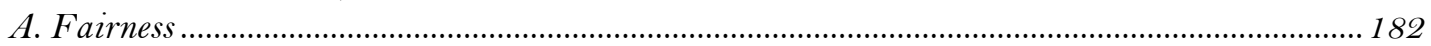

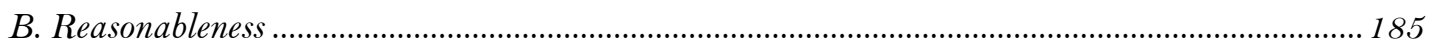

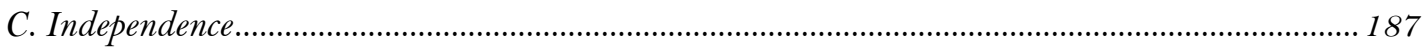

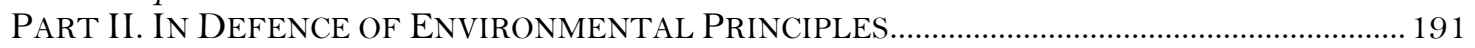

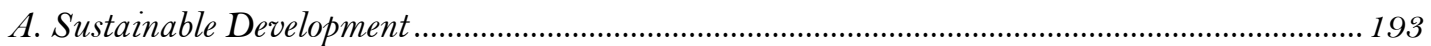

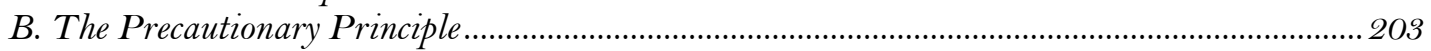

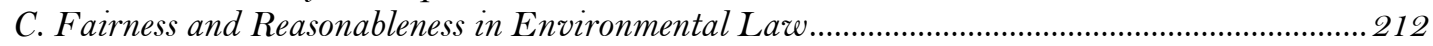

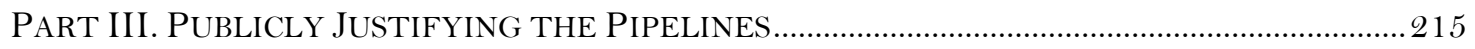

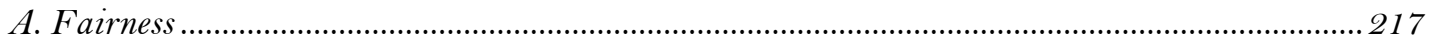

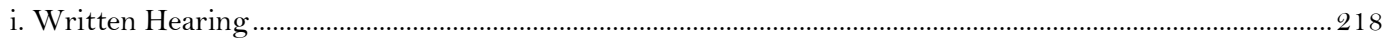

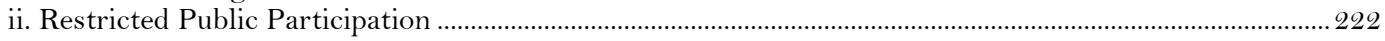

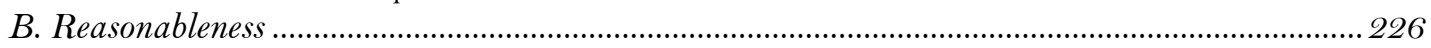

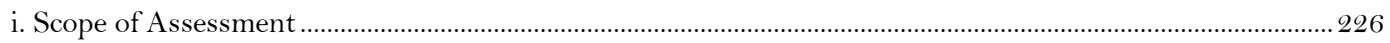

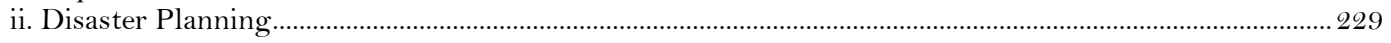

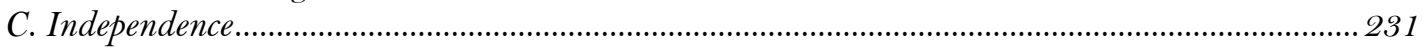

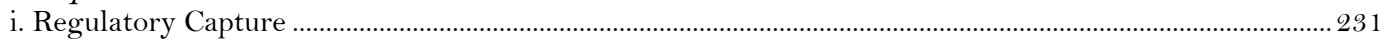

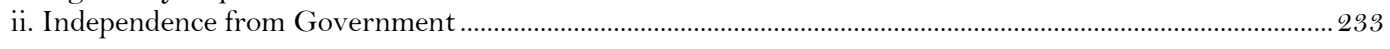

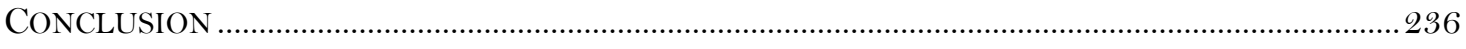

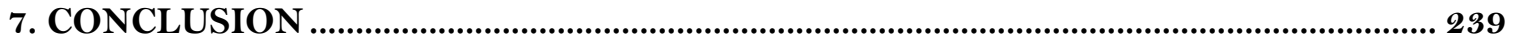

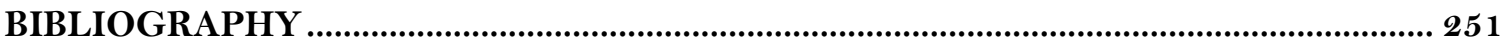




\begin{abstract}
This thesis argues that environmental issues present an ongoing emergency, and that to understand the relationship between law and the environment we need to take the ongoing emergency seriously. Like emergencies, environmental issues possess two salient epistemic features: the inability to know in advance which issues contain the possibility of catastrophe, and the inability to know in advance what to do in response to a catastrophe. These features undermine the assumption that law can be equated with predetermined legal rules set out by the legislature and enforced by the courts. By developing a framework based on the concept of the environmental emergency, the thesis reveals and critiques the assumptions about law contained in existing accounts of Canadian environmental law. It then offers an account of the rule of law that requires public officials to publicly justify their decisions on the basis of core constitutional principles, namely reasonableness and fairness.
\end{abstract}

In elaborating these principles, I draw out connections between common law constitutionalism and theories of deliberative democracy. I then develop an account of how the administrative state can be governed by a democratic conception of the rule of law. The crux of this account is that it protects the autonomy of individuals, understood as rational and selfdetermining agents, and their capacity to actively participate in environmental governance. By requiring public officials to publicly justify their decisions on terms that citizens can understand and reasonably accept, this deliberative and constitutional account allows citizens to obey or contest the law. It thereby enables their participation in the project of articulating and re-articulating core constitutional principles. The thesis also explains how creative institutional design is essential to maintaining public justification in the environmental context. On this view, specialized appeals tribunals, auditor generals and ombudsmen are not unfortunate (if necessary) deviations from the rule of law, but a fuller realization of its ideals in the complex regulatory context of environmental decision-making. I argue that well-known environmental principles of sustainable development and precaution can be defended on the basis that they safeguard the relationship between citizens and state that public justification makes possible. 


\section{Résumé}

La thèse soutient que les problèmes environnementaux présentent une urgence continue et que, pour comprendre la relation entre le droit et l'environnement, nous devons prendre au sérieux cette urgence continue. Comme toute urgence, les problèmes environnementaux possèdent deux importantes caractéristiques épistémiques : l'incapacité de savoir à l'avance quels problèmes peuvent conduire à la catastrophe, et l'incapacité de savoir à l'avance comment répondre à une catastrophe. Ces caractéristiques contredisent la préconception selon laquelle on peut assimiler le droit à des règles juridiques prédéterminées, établies par la législature et appliquées par les cours de justice. À partir d'un cadre conceptuel fondé sur la notion d'urgence environnementale, la thèse révèle et critique les préconceptions au sujet du droit renfermées dans des représentations actuelles du droit canadien de l'environnement. Elle offre ensuite une conception de l'état de droit exigeant que les fonctionnaires justifient publiquement leurs décisions sur la base de principes constitutionnels fondamentaux, soit la raisonnabilité et l'équité.

En élaborant ces principes, j’effectue des liens entre le constitutionalisme de common law et des théories de démocratie délibérative. J'expose ensuite comment l'État administratif peut être gouverné par une conception démocratique de l'état de droit. Essentiellement, cette conception protège l'autonomie des individus, considérés comme des agents rationnels capables d'autodétermination, et leur capacité à participer activement dans la gouvernance environnementale. En exigeant des fonctionnaires qu'ils justifient publiquement leurs décisions en des termes que les citoyens peuvent comprendre et raisonnablement accepter, cette conception délibérative et constitutionnelle permet aux citoyens d'obéir au droit ou de s'y opposer. Elle permet ainsi leur participation au projet de formuler et de reformuler les principes constitutionnels fondamentaux. La thèse explique également comment faire preuve de créativité dans la conception des institutions est essentiel pour maintenir la justification publique dans le contexte environnemental. À ce propos, les tribunaux d'appel spécialisés, les vérificateurs généraux et les ombudsmans ne sont pas des déviations regrettables (quoique nécessaire) de l'état de droit, mais plutôt une réalisation plus complète de ses idéaux dans le contexte règlementaire complexe du processus décisionnel environnemental. Je soutiens que les principes environnementaux bien connus de précaution et de développement durable peuvent être défendus sur la base qu'ils protègent la relation entre citoyens et État rendue possible par la justification publique. 


\section{Acknowledgements}

I am tremendously fortunate to have had Evan Fox-Decent as my supervisor. It goes without saying that this thesis would not be here today without his guidance and steadfast confidence in my ability to complete this project. Evan encouraged me to think much bigger than I ever would have thought possible. He provided innumerable comments and questions and much needed encouragement that always pushed me to think deeper and more critically about my arguments.

I benefited greatly from having two extremely dedicated committee members, Shauna Van Praagh and Hoi Koi. I am very grateful for their mentorship throughout my doctorate. Thanks to Hoi, in particular, for his patience and guidance as I worked through the arguments in chapters 4 and 5. The ideas formulated in the thesis have been informed by many helpful conversations with members of the McGill Faculty of Law. I owe a very special thanks to my friend and colleague, Kate Glover, who has been with me every step of the way.

I was fortunate to be part of two thesis peer review groups, which were crucial to moving the thesis forward when it would have otherwise stalled. Special thanks to Dia Dabby, Bethany Hastie and Francis Lord who contributed many helpful comments on early drafts of chapters 2 , 3 and 5. Thanks also to Francis for providing me with the French translation of the abstract. Thanks to the participants in Hoi Kong's 2014-2015 DCL seminar who offered feedback on chapters 4 and 5 . I benefited from feedback from audiences at the McGill Faculty of Law, Yale Law School, Australia National University College of Law, Centre for Deliberative Democracy and Global Governance, and the University of British Columbia Allard School of Law. As some of the arguments contained in this thesis are now published in the Osgoode Hall Law Journal, I would also like to acknowledge the comments and critiques offered by two anonymous reviewers and one non-anonymous reviewer, Bruce Pardy.

The research for this thesis was funded by a SSHRC Joseph Bombardier Canada Graduate Scholarship and the McGill Faculty of Law. Portions of this thesis are in press as: "The Environmental Emergency and the Legality of Discretion in Environmental Law” (2016) 53 OHLJ forthcoming, available online: Social Science Research Network < ssrn.com>.

I completed this thesis while living in Brisbane, Australia. I am fortunate to have been invited to the Centre for Deliberative Democracy and Global Governance on two separate occasions, where I benefited from conversations with many of the leading scholars in the field of deliberative democracy. Thanks to the School of Geography, Planning and Environmental Management at the University of Queensland for unofficially providing me a place to work while finishing the thesis abroad. Thanks to Karen Crawley, a McGill DCL, without whom my time in Brisbane would have been very lonely. 
To Ross and Cathy Stacey, thanks for your love and encouragement right from the beginning. To Alice Woolley, thank you for encouraging me to consider pursuing academia. I cannot imagine having undertaking a doctorate in law were it not for your timely intervention during my LLB. I reserve my biggest thanks for Matthew Mitchell for his unwavering support and Harriet Mitchell for putting it all in perspective. 


\section{List of Acronyms}

CEAA Canadian Environmental Assessment Act

FPB Forest Practices Board

FRPA Forest and Range Practices Act

FSC Forest Stewardship Council

GBRA Great Bear Rainforest Agreement

NEB National Energy Board

NEBA National Energy Board Act

NGO Non-Governmental Organization

RCMP Royal Canadian Mounted Police 


\section{Introduction}

This thesis strives to elaborate a theory of environmental law. Until now no rigorous account of environmental law has combined ecological theory with a sophisticated understanding of the rule of law. That such a theory is lacking may seen surprising since environmental law, as a distinctive sub-field, is a now a permanent fixture of the legal landscape. As some environmental law scholars have noted, however, appearances can be deceiving and a deep disconnect between law and environmental protection remains. ${ }^{1}$ One prominent environmental law scholar has argued that environmental law is "hot law" because "the agreed frames, legal and otherwise, for how we understand and act in the world are in a constant state of flux and contestation." 2 Environmental issues are complex in almost every wayscientifically, politically, and disciplinarily. They challenge our most basic assumptions about what it means to be governed by law, which typically transpires through general, relatively stable rules enacted in advance by the legislature and interpreted by the courts. In other words, the complexity of environmental issues presents a fundamental problem for understanding how law can both constitute and constrain the state's regulative authority over the environment.

I argue that the best way to understand the challenge that environmental issues pose for law is through the lens of an ongoing emergency. Like emergencies, environmental issues require decisions to be taken under conditions of deep uncertainty where the possibility of a catastrophe cannot be reliably eliminated in advance. We can thus glean important theoretical

\footnotetext{
${ }^{1}$ David Boyd, Unnatural Law: Rethinking Canadian Environmental Law and Policy (Vancouver: UBC Press, 2003), A Dan Tarlock, "Is There a There There in Environmental Law?” (2003) 19 J Land Use \& Envtl L 213.

${ }^{2}$ Elizabeth Fisher, "Environmental Law as 'Hot' Law" (2013) 25 JEL 347 at 347-8 [Fisher]. See also Andreas Philippopoulos-Mihalopoulos, "Looking for the space between law and ecology" In Andreas PhilippopoulosMihalopoulos ed, Law and Ecology: New Environmental Foundations (London: Routledge, 2011) 1 (on the radical potential of environmental law).
} 
insights from legal theory on conventional emergencies to develop a better understanding of the relationship between law and environmental issues. The central challenge of emergencies is succinctly captured in the work of controversial Nazi legal theorist, Carl Schmitt. Schmitt argues that the unforeseeable, existential threat-the exception or emergency-necessitates unconstrained executive discretion. He argues, in other words, that the emergency cannot be governed by law. Schmitt's argument thus poses a fundamental challenge for legal scholars writing about national security emergencies post-9/11. They must show how exceptional, discretionary emergency response measures can be compatible with a legal system otherwise defined by its commitment to the rule of law. Schmitt's challenge and its potential responses provide the framework for understanding and responding to the challenge that environmental issues pose for law.

The deep complexity of environmental issues gives rise to the concept of the environmental emergency at the centre of the thesis. The environmental emergency provides a useful framework for the analysis that unfolds through the substantive chapters of the thesis. More importantly, the emergency perspective leads to the development of a sophisticated account of the rule of law. This concept of the environmental emergency requires us to reject a formal conception of the rule of law, which rests on unrealistic assumptions about legislatures and courts as lawmakers and law-interpreters, respectively. These assumptions are brought to the surface in the face of so-called "super wicked problems" ${ }^{\text {in }}$ in the environmental context. Because they possess the features of an ongoing emergency, these problems often seem to demand either unfettered executive discretion or innovative and networked governance arrangements, neither of which square with a formal conception of the rule of law. We

\footnotetext{
${ }^{3}$ Richard J Lazarus, "Super Wicked Problems and Climate Change: Re-straining the Present to Liberate the Future" (2009) 94 Cornell L Rev 1153 at 1160.
} 
therefore need an account of the rule of law that refocuses our attention on what makes law something worth having in the first place and then explains how it can be sustained even under conditions of profound complexity and uncertainty, with the threat of catastrophe ever present.

In this thesis, I defend an understanding of the rule of law as a project; that is, as a collective effort of all institutions of government to publicly justify decisions on the basis of core constitutional values. I build on the work of Lon Fuller, David Dyzenhaus and others who argue that what makes law law-that is, what gives law its authority-is its compliance with the rule of law. This authority derives from the fact that the rule of law respects the autonomy of individuals, understood as rational and self-determining agents. An ongoing requirement of public justification enables individuals to reason with the law. It obliges public decision-makers to justify their decisions with reasons that individuals can understand and reasonably accept. Individuals can then choose whether to obey the law or contest it. Through this reasoning process, they are active participants in the rule-of-law project of ensuring public decisions reflect our best understanding of our core constitutional values and how they can be fulfilled in any given case.

The theory presented here is an extension of common law constitutionalism. This form of constitutionalism holds that the common law, with its long historical evolution, reflects the deeply rooted values that are constitutive of the community. On this view, public officials must justify their decisions on the basis of core common law constitutional principles. Judges are entitled to intervene when a public decision is successfully contested on the basis that it does not reflect these principles. Two of these deeply rooted common-law principles are fairness and reasonableness. Put differently, the conception of the rule of law defended here is grounded in 
the administrative law requirements of procedural fairness and reasonableness. These requirements, properly elaborated, provide a stable framework for the individual's exercise of her autonomy, understood as the capacity to reason with the law. As we will see, this ongoing commitment to public justification requires further development in the environmental context. Drawing on deliberative-democratic theory, I argue that public justification requires creative institutional design to ensure that complex and contentious decisions reflect core constitutional principles. It also requires the elaboration of fairness and reasonableness in light of existing environmental principles, such as the precautionary principle and sustainable development, which are themselves contested and often ambiguous.

The thesis distinguishes itself from most environmental law scholarship in that it does not attempt to solve any particular environmental problem. Rather, it articulates a theory of how the administrative state can be governed by a democratic conception of the rule of law, elaborated, as it needs to be, for the special challenges posed by environmental issues. The context for the thesis is therefore the realm of public administration, or what I will refer to as administrative decision-making.

While immediate reform is not the primary objective of the thesis, there are important normative implications that follow from the theory developed here. We will see that the ruleof-law theory advanced in this thesis requires an assessment of the capacity of existing institutions of government to generate reasoned environmental decisions. It requires a further assessment of whether effective avenues exist through which citizens can contest decisions that are not perceived as justified. These may seem like rather simple requirements, but they are difficult to meet under conditions of an ongoing emergency, and this thesis provides numerous 
examples where existing institutions fall short in Canadian environmental law. A second implication is also worth making clear in light of changes to Canadian environmental law at the federal level since 2006. Environmental law scholars have observed that the federal government, during this period, has repeatedly undermined environmental protection on nearly every front. ${ }^{4}$ Within the existing framework of constitutional and international law, Parliament is relatively unconstrained in how far it can rollback environmental protection. The theory defended here shows how the other institutions of government are entitled to resist these changes to a point; they can force Parliament to be completely direct and unambiguous in its decisions to harm the environment and not allow it to hide behind a façade of legality.

While the theory is not necessarily tied to any particular State, it is developed in the context of Canadian environmental and administrative law. Canada presents particularly fruitful and largely unexplored terrain on which to construct a theory of environmental law based on common law constitutionalism. Canadian jurisprudence has proven fertile ground for common law constitutionalism, ${ }^{5}$ which as we will see provides a persuasive response to the challenge of emergencies. To date, common law constitutionalism has largely ignored the policy-dominated regulatory domain. In addition, we will see that Canadian law and policy is deeply ambivalent about environmental protection. Canadian environmental law is the product of a wilderness or preservationist national identity and a natural resource exploitation reality. ${ }^{6}$ Canada thus presents a hard case for understanding how the rule of law ought to operate in

\footnotetext{
${ }^{4}$ Jason McLean, Meinhard Doelle and Chris Tollefson, "The Past, Present and Future of Canadian Environmental Law: A Critical Dialogue” (2015) Lakehead LJ forthcoming (noting that nearly all major federal environmental statutes have been significantly amended to weaken environmental protection). E.g. Chapter 6 infra.

${ }^{5}$ Evan Fox-Decent, Sovereignty's Promise: The State as Fiduciary (Oxford: Oxford University Press, 2011); David Dyzenhaus, The Constitution of Law: Legality in a Time of Emergency (Cambridge: Cambridge University Press, 2006); Mark D Walters, “The Common Law Constitution in Canada: Return of Lex Non Scripta as Fundamental Law” (2001) 51 UTLJ 91.

${ }^{6}$ Stepan Wood, Georgia Tanner and Benjamin J Richardson, "What Ever Happened to Canadian Environmental Law?” (2011) 37 Ecology LQ 981 at 981, 986-7.
} 
light of these deeply conflicting environmental values. In other words, environmental issueslike emergencies - can force us to re-examine the "agreed legal frames" in both public and environmental law.

\section{Methodology, Terminology and Context}

By adopting a conceptual methodology I aim to explain what it means to govern the environment by law. I refer to this conceptual framework as the environmental emergency because it is built on the argument that environmental issues contain the constitutive features of an emergency. The environmental emergency allows us to uncover and critique existing rule-oflaw assumptions in Canadian environmental law and develop an alternative account of the rule of law that takes seriously the complexity of environmental issues. The rule-of-law theory developed within this thesis, however, follows a tradition of democratic pragmatism. ${ }^{7}$ Understanding the rule of law as a certain kind of project-as an ongoing commitment to public justification-means that its content is never fixed. Public justification is essential to the process of realizing, deliberating upon and rearticulating core constitutional principles. The methodology for developing this conception of the rule of law, as we will see in Chapters 5 and 6 , is to draw out theoretical insight from existing institutional practices that do especially well (or poorly) at fostering a commitment to public justification.

The rule of law is often labelled an "essentially contested concept," because it "inevitably involves endless disputes about [its] proper use[ $\left[\right.$...." ${ }^{8}$ We will see that two conceptions of the

\footnotetext{
${ }^{7}$ I borrow this term from John S Dryzek, The Politics of the Earth: Environmental Discourses 3d ed, (Oxford: Oxford University Press, 2013) at 99. By pragmatism I mean the philosophical pragmatism of Charles Peirce and John Dewey. This is addressed in Chapter 5 in the discussion of democratic experimentalism and its intersection with common law constitutionalism.

${ }^{8}$ WB Gallie, "Essentially Contested Concepts" (1955) 56 Proceedings of the Aristotelian Society 167 at 169 ; Jeremy Waldron, "Is the Rule of Law an Essentially Contested Concept (in Florida)?” (2004) 21 Law \& Phil 137.
} 
rule of law will be contrasted in this thesis. The first conception, which I refer to as the formal conception, is developed in the first three chapters. The formal conception of the rule of law emphasizes the requirement of a formal allocation of distinct powers between institutions of government. The formal conception, put differently, is largely commensurate with a strong separation of powers. The second conception of the rule of law is the theory developed in the thesis that, at base, requires public decision-makers to publicly justify their decisions on the basis of core constitutional principles. I refer to this as the public-justification conception or the requirement of public justification. By the end of the thesis, however, no such qualifying language should be necessary. The argument here is both normative and comprehensive, that is, the public-justification conception of the rule of law developed and advocated for in the thesis can and should operate for all issues at all times.

Environmental law also suffers from somewhat of an identity crisis. The environment is all around us. Humans are part of it and virtually every public decision has some effect on the environment whether intended or not. Many have therefore advocated an expansive understanding of environmental law that requires rooting out the unsustainable practices "embedded in every aspect of economic and political life."9 The conventional understanding of environmental law, in contrast, tends to focus on regulating specific human activities that have direct effects on environmental and human health: e.g., air and water pollution laws, endangered species protection, the regulation of natural resource development. Since the ruleof-law theory developed here is comprehensive, nothing important turns on this distinction. As will become clear, the focus of the thesis is on conventional environmental law and, in

\footnotetext{
${ }_{9}^{9}$ Michael M'Gonigle and Paula Ramsey, "Greening Environmental Law: From Sectoral Reform to Systemic ReFormation" (2004) 14 JELP 333 at 340. See also Jane Holder, "New Age: Rediscovering Natural Law" (2000) 53 CLP 151 at 167 .
} 
particular, the conflicts between natural resource exploitation and environmental protection. While the specific case studies are essential for my methodology, the systemic features of all environmental issues are what justify approaching these issues as an ongoing emergency. By this I mean the features of complexity and the ever-present possibility of an environmental catastrophe. After making this argument in Chapter 2, I will refer to these features simply as complexity as opposed to uncertainty, risk, or some other descriptor. As we will see, complexity best captures the kind of uncertainty we face when regulating the environment, and it is this complexity that constitutes the environmental emergency.

Before moving to the outline of the thesis, it is worth situating the theoretical argument in its socio-political context. This requires that I identify and respond to two principal objections to the central argument that environmental issues are best understood as an ongoing emergency. The first objection is that, at least in many liberal Western democracies, most environmental issues have not sparked the overzealous state action that characterizes many conventional emergency responses. For example, in Canada, Australia and the United States state action on perceived environmental and national security threats have starkly diverged. Counter-terror measures have proliferated whereas state action on pressing environmental issues, such as climate change, has stagnated or regressed. ${ }^{10}$ This seems to suggest that the problem in the environmental context is not law's inability to constrain political power as it is in the national security emergency context. In this respect, many environmental law scholars might long for the kind of preventive state action that has emerged post 9/11.

\footnotetext{
10 There is a wealth of (largely American) legal research that examines the reasons for widespread lethargy in response to chronic environmental issues: hypothesizing and documenting the collective action problem, discounting future harm, cognitive decision-making biases. For one such example specific to this point, see: Cass R Sunstein, "On the Divergent American Reactions to Terrorism and Climate Change" (2007) 107 Colum L Rev 503.
} 
I agree with this general observation. What this perspective misses, however, is the fact that environmental issues and emergencies present the same core challenge for law. As we will see in Chapter 2, it is the combination of epistemic features possessed by both emergencies and environmental issues that pose particular challenges for the rule of law. Moreover it is important to note that, while environmental issues are frequently exacerbated by a lack of political will, they do not exist in a complete legal void. In Canada, the provinces, territories and Parliament have elected to govern the environment through law. The argument of this thesis is that this is a meaningful commitment, one that entails much more extensive and nuanced legal obligations than the enactment of a symbolic or perhaps equivocal statute.

The second objection might call into question the value of presenting a unifying theory across either environmental law or public law. As I have just noted, environmental law is potentially all encompassing and it contains "hot problems" that resist unified frameworks. ${ }^{11}$ Narrowing the field to public environmental law offers little help. The Canadian administrative state is comprised of an intricate network of public decision-making bodies including Cabinet, Ministers, appeals tribunals and quasi-judicial regulatory bodies, which issue and review recommendations, regulations, licenses, exemptions and approvals covering an enormous range of activities that impact the environment. Perhaps, as prominent public law scholars have argued, we should view our legal system as pluralistic, where statutes are permitted to "lead a life of their own," independent of the homogenizing tendencies of the common law. ${ }^{12}$

\footnotetext{
${ }^{11}$ Fisher, supra note 2 at 354-5 (also observing that environmental law scholarship has as of yet failed to yield such a framework).

${ }^{12}$ Harry W Arthurs, "Rethinking Administrative Law: A Slightly Dicey Business" (1979) 17 OHLJ 1 at 22 . See also Sean Coyle \& Karen Morrow, The Philosophical Foundations of Environmental Law: Property, Rights and Nature (Oxford: Hart Publishing, 2004) at 199-200 [Coyle and Morrow] (arguing that the dominant view of environmental law is as a haphazard collection of legislative responses that does not contain the deeper conception of responsibility that they trace back through the history of common law property rights).
} 
The unified theory of public environmental law that I present is both defensible and valuable. It is defensible in that it does not purport to offer a blanket approach to addressing any or all environmental issues. Rather, it focuses on understanding the conditions under which the State can be said to act with legal authority when it regulates the environment. I argue that public environmental decisions will have legal authority when they are publicly justified on the basis of core constitutional principles. As we will see in Chapter 6, these principles operate at a high-level of generality, but they are not abstract; they are sensitive to the particular decisionmaking context. In addition to being defensible, a coherent theory of environmental law is also valuable to the discipline. Despite the interconnectedness of environmental issues in the real world, the field of environmental law is marginalized from other areas of public law and increasingly fragmented. ${ }^{13}$ This means that systemic flaws or weaknesses in environmental decision-making may be overlooked. For example, we will see in Chapter 3 that the outcomes of judicial review of a wide range of environmental decisions can be explained by a common set of rule-of-law assumptions held by the courts and environmental advocates. Striving for a unified theory of environmental law allows us to focus on the core challenges of environmental issues to better understand the limits and potential of existing public law theory.

\section{Outline of Thesis}

Five substantive chapters comprise this thesis. The first substantive chapter, Chapter 2, makes the case for approaching environmental law from the perspective of an emergency. This chapter is grounded in current ecological theory which posits that ecosystems are complex,

\footnotetext{
${ }^{13}$ Elizabeth Fisher et al, "Maturity and Methodology: Starting a Debate about Environmental Law Scholarship" (2009) 21 JEL 213 at 221 and 231; Lisa Heinzerling "The Environment" In Peter Cane and Mark Tushnet eds, The Oxford Handbook of Legal Studies (Oxford: Oxford University Press, 2003) 701 at 703-4; Coyle and Morrow supra note 12.
} 
adaptive systems. We will see that the characteristics of complex, adaptive systems give rise to the constitutive features of an emergency: an inability to know in advance which issues contain the possibility of a catastrophe and an inability to know in advance what to do in response to such an unforeseen event. Because we cannot confidently identify in advance which environmental issues or policy choices contain the possibility of a catastrophe, the emergency perspective must operate for all of environmental law. I illustrate this argument with the example of the unprecedented mountain pine beetle epidemic in Western Canada that now threatens the entire Canadian boreal forest. Having made the argument that environmental issues are best approached as an ongoing emergency, the chapter then sets out Schmitt's challenge: i.e., the challenge to show that emergencies can be governed by law. I will canvass two potential responses to this challenge-the extra-legal approach and an accommodation approach — which provide a background framework for understanding the arguments in the two chapters that follow. Chapter 2 concludes by arguing that both of these responses assume a formal conception of the rule of law that is incapable of answering Schmitt's challenge.

Chapters 3 and 4 argue that the emergency framework provides a novel critique of existing approaches to environmental law. In Chapter 3, I argue that the dominant position in Canadian environmental law scholarship - the environmental reform position-does not face up to the emergency features inherent in environmental issues. It therefore mistakenly advocates for a formal conception of the rule of law. Much like the accommodation approach in the emergency literature, the environmental reform position can only offer a façade of legality to environmental decisions, an appearance of legality that does not meaningfully constrain the exercise of administrative discretion. I argue that this façade is helpfully understood as legal 
black holes and grey holes. I illustrate how adherence to the formal conception of the rule of law has created these black and grey holes throughout Canadian environmental law.

Chapter 4 takes up the burgeoning literature on environmental governance. I argue that the literature correctly diagnoses the epistemic challenges of environmental issues. But because it assumes a formal conception of the rule of law, it rejects the rule of law as irrelevant to complex environmental decision-making. Much like the extra-legal approach, environmental governance proponents treat the rule of law as a luxury that we cannot afford. Instead, commentators evaluate environmental governance on the basis of an assortment of criteria; typically effectiveness, transparency, participation, and accountability. And while these criteria may be important components of any conception of the rule of law, they are, at best, only components. I argue that, by abandoning the concept of the rule of law, governance scholars have missed what is distinctive about law-the fact that it respects individuals as rational agents capable of actively participating in their own system of governance. They have therefore abandoned the language needed to fully explain the strengths and weaknesses of novel forms of environmental governance.

Chapters 5 and 6 shift from critique to the elaboration of a democratic theory of the rule of law that responds to the environmental emergency. Chapter 5 draws out the publicjustification conception from existing Canadian administrative law jurisprudence and argues that it responds to Schmitt's challenge. The crux of this chapter is that, in emergency contexts (including the environmental emergency), creative institutional design will be necessary to maintain the rule of law. The chapter offers the example of the British Columbia Forest Practices Board, a hybrid institution that approximates in unconventional ways the 
requirements of public justification across a range of environmental decisions. The chapter then draws on insights from democratic experimentalism - a branch of deliberative democracy — to show how public justification can be maintained even in complex regulatory contexts. From these examples, I tease out the intersections between common law constitutionalism and deliberative democracy to articulate an account of the rule-of-law project, a project that respects the individual's capacity to reason with the law.

Chapter 6 takes this aspirational account of the rule of law and shows that it imposes concrete requirements on environmental decision-makers facing highly contentious and complex decisions. This chapter focuses on a case study of Canada's National Energy Board and its mandate to advise the Governor in Council on the approval of major interprovincial pipelines. These pipelines are extremely contentious, front-page news in Canada, precisely because of their connection to potential environmental emergencies. If constructed, they entrench Canada's commitment to controversial Alberta oil sands development and they create the threat of a catastrophic oil spill. Chapter 6 argues that the requirement of public justification is capable of meaningfully governing the pipeline approval process. To this end, it offers a defence of well-known environmental principles: sustainable development and precaution. I argue that, when interpreted in light of deliberative-democratic ideals, these principles can be understood as an attempt to maintain the distinctive relationship between legal subject and state that the public-justification conception of the rule of law makes possible. These principles, therefore, have the effect of modifying general common law requirements of fairness and reasonableness in order to impose meaningful constraints on the National Energy Board's assessment mandate. 
In sum, the thesis develops a constitution of the environmental emergency. I mean "constitution" in two senses of the term. First, the five substantive chapters together construct the concept of the environmental emergency, a concept that has three components. The internal constitution of the environmental emergency is part conceptual (Chapter 2), part critique (Chapters 3 and 4), and part theory development (Chapters 5 and 6). But the term "constitution" also connotes the fact that the theory of the rule of law developed in this thesis posits that the rule of law is constitutive of law itself. In other words, the thesis explains why having environmental law is something worth having. The assumption underlying most environmental law scholarship to date is that environmental law is the most powerful tool for protecting the environment. The account offered here shows that environmental law is not only that. Environmental law, in the sense defended in the thesis, makes the reasoning and selfdetermining capacity of individuals internal to the project of environmental governance. It enables citizens to actively participate in the ongoing commitment to ensuring that environmental decisions reflect our best understanding of core constitutional principles. When public officials appeal to the legality of their decision-e.g., 'the statute permits me to convert this pristine lake into a toxic tailings pond'-this comes with its own kind of legitimacy. ${ }^{14}$ The challenge, therefore, is to understand the rule of law, or legality, as something meaningful. The rule-of-law project, with its ongoing commitment to creative institutional design to enable public justification, answers this challenge.

\footnotetext{
${ }^{14}$ David Dyzenhaus, "The Legitimacy of Legality” (1996) 46 UTLJ 129. This is central to ecofeminist perspectives on environmental law. See, e.g.: Elaine L Hughes, "Fishwives and Other Tails: Ecofeminism and Environmental Law” (1995) 8 CJWL 502. Chapter 3 infra covers numerous examples where an administrative decision-maker appeals only to the scope of delegated discretion to justify making an environmentally harmful decision.
} 


\section{The Environmental Emergency and the Problem for}

In October 1970, Canada faced its worst internal security crisis, when cells of the violent separatist group, Le Front de Liberation du Quebec (FLQ) kidnapped the British Trade Commissioner... and kidnapped and later murdered the Quebec Minister of Labour.... Faced with this mushrooming crisis, Canada acted swiftly and forcefully with no regard for civil liberties. Invoking the War Measures Act under a putative, and unproven, apprehended insurrection, the federal government placed Quebec under what amounted to a state of martial law. ${ }^{1}$

After riding thermals for 190 miles from British Columbia, the insects fell like rain out of the sky. Farmers heard them ping on the roofs of metal barns. Hungry and fatigued, the beetles quickly hit more than 300,000 lodgepole trees... On each tree, they produced enough off-spring to attack another ten. Hardly a newspaper carried the story. It was, after all, just a story about trees. ${ }^{2}$

\section{Introduction}

This chapter argues that we should approach environmental law from the perspective of an ongoing emergency. By an ongoing emergency I do not mean a continual cycle of natural disasters - earthquakes, oil spills, and the like. As I explain in this chapter, the systemic features of environmental issues give rise to the constitutive features of an emergency such that we should view all of environmental law from the perspective of the emergency.

The connection between emergencies and environmental issues is not necessarily obvious. As the epigraph suggests, conventional emergencies are dramatic and sudden events that temporarily displace any semblance of normalcy. In contrast, most environmental issues are persistent challenges that we address through everyday administrative law channels such as

\footnotetext{
${ }^{1}$ Reg Whitaker, "Keeping Up with the Neighbours? Canadian Responses to 9/11 in Historical and Comparative Context" (2003) 41 Osgoode Hall LJ 241 at 249.

${ }^{2}$ Andrew Nikiforuk, Empire of the Beetle (Vancouver: Greystone Books, 2011) at 74 [Empire].
} 
regulation-making and licensing. This chapter argues, however, that this distinction is more apparent than real. The challenge of both environmental issues and emergencies is that we cannot reliably anticipate an extreme event and therefore cannot know in advance how to respond. The emergency, in other words, undermines any conception of the rule of law that equates law with pre-existing rules. It reveals the inevitability and necessity of executive discretion.

This chapter proceeds in three parts. In the first part I introduce the challenge of emergencies. This challenge was posed by controversial Nazi legal scholar Carl Schmitt, who argued that the unforeseeable, extreme threat cannot be governed by law. I argue that environmental issues constitute emergencies because they contain the unforeseeable possibility of a catastrophe. The complex, adaptive nature of ecological systems means that it is impossible to fully anticipate the effects of our actions on the environment. Environmental issues are characterized by indeterminacy and ignorance. The nature of the problem and our understanding of it are constantly evolving. Surprises, sometimes catastrophic surprises, are therefore inevitable. The fact that we cannot always know in advance which issues contain the possibility of catastrophe means that we must approach all environmental issues from the perspective of the emergency.

In the second part of the chapter, I take up two possible responses to Schmitt's challenge. We will see that Schmitt assumes a formal conception of the rule of law; that is, he equates law with relatively determinative legislated rules. For those who adhere to the formal conception of the rule of law there are only two possible responses to the emergency: resort to extra-legal measures or attempt to accommodate emergencies within legal order by relaxing 
ordinary rule-of-law requirements. I argue that both approaches rest on a dualist fiction. They attempt to create dual legal orders (one for ordinary times and another for crises). But the very fact that emergencies cannot be anticipated undermines this attempt to confine a separate emergency order. Moreover, the attempt to accommodate the emergency within legal order risks proliferating legal black and grey holes, which give only the appearance and not the reality of legal constraint. In short, these emergency responses only help bolster Schmitt's claim that the emergency cannot be governed by law.

In the third part I show that Schmitt's challenge extends to the entire administrative state. The emergency, as Schmitt notes, poses a glaring problem for the formal conception because it reveals the necessity of unconstrained discretion. But broad legislative grants of power to the executive are now characteristic of the modern administrative state. The exercise of exceptional and everyday discretionary powers pose the same problem for the formal conception of the rule of law: the problem of discretion. We will see that Schmitt's followers observe that the modern administrative state is filled with legal black and grey holes. By the end of the chapter, we will have the necessary foundation for subjecting environmental issues, understood as an ongoing emergency, to Schmitt's challenge.

\section{Part I. The Environmental Emergency}

The concept of the environmental emergency arises from the complex, adaptive nature of environmental issues. In this part we will see that the emergency is any unforeseeable, extreme threat that cannot be anticipated through ex ante legal norms. I argue that serious environmental issues constitute emergencies because they have catastrophic potential but, due to their complexity, it is impossible to know in advance the precise details of the catastrophic 
threat. Indeed, as we shall see, the extent of complexity is often so great that it precludes knowing in advance which environmental issues contain the chance of catastrophe. In this part, I first introduce the conventional emergency and the problem it poses for the rule of law. I then make the case for the concept of the environmental emergency. Here I will sketch a brief case study, the mountain pine beetle epidemic, to illustrate how serious environmental issues possess the constitutive features of an emergency (and which I will return to in subsequent chapters). I then argue that the environmental emergency can serve as a unifying conceptual framework for all of environmental law.

\section{A. Schmittian Emergencies}

Emergencies have long posed a problem for political and legal theorists. Emergencies strain our commitment to the rule of law. The sudden and extreme nature of emergencies demands urgent action. Crises cause us to rally around the flag, which motivates the government to take whatever measures are necessary to bring the emergency to an end. Often these exceptional measures violate or curtail constitutional commitments to basic civil liberties and ordinary due process. ${ }^{3}$ The historical record suggests that the legislature and courts do not present significant constraints on executive emergency action. Legislatures may delegate broad emergency powers to the executive in advance, ${ }^{4}$ and courts tend to defer to the executive because they are reluctant to interfere with the sensitive and high-stakes issues that pertain to

\footnotetext{
${ }^{3}$ Oren Gross \& Fionnuala N Aolain, Law in Times of Crisis (New York: Cambridge University Press, 2006) at 64 [Law in Times of Crisis].

${ }^{4}$ For example, War Measures Act, RSC 1970, c W-2 [repealed]; Emergencies Act, RSC 1985, c 22 (4th Supp); Emergency Management Act, SC 2007, c 15.
} 
an emergency response. ${ }^{5}$ In short, emergencies appear to demand exceptional executive action, that is, action determined by necessity and unconstrained by law.

Legal theorist Carl Schmitt offers a theoretical account of this historical pattern. His argument is simple but powerful. The emergency, according to Schmitt, cannot be governed by law. Schmitt describes the emergency as the unforeseeable, existential threat that cannot be anticipated in law. ${ }^{6}$ Since the emergency is unexpected it cannot be defined through ex ante legal rules, and its severity demands an urgent response which makes it impossible to respond through the ordinary legislative process. ${ }^{7}$ Because the emergency cannot be regulated through positive legal norms, Schmitt maintains that the best that can be done is to indicate who gets to decide that such an emergency exists and what to do in response. ${ }^{8}$ For Schmitt, only the sovereign (or the modern day executive) can fulfill this role. Schmitt argues that in the event of a truly existential threat the sovereign may even need to suspend legal order altogether. ${ }^{9}$ Any attempt to prescribe how the sovereign must respond to the emergency is undermined by the fact that the emergency cannot be predicted in advance, and therefore may require the violation of pre-existing rules. The fact that the sovereign is so empowered reveals that he or she is in the position to respond most expeditiously to serious, though not existential threats. ${ }^{10}$ In the face of an unforeseeable and extreme emergency, Schmitt argues, the sovereign can do

\footnotetext{
${ }^{5}$ Law in Times of Crisis, supra note 3 at 77-8 (observing judicial reluctance to intervene by invoking threshold barriers such as political questions doctrine or standing, and showing extreme deference to governmental claims when it does review on the merits).

${ }^{6}$ Carl Schmitt, Political Theology, translated by George Schwab (Cambridge, Mass: MIT Press, 1985) at 6 [Schmitt].

${ }^{7}$ Schmitt observes that " $[\mathrm{t}]$ he precise details of an emergency cannot be anticipated, nor can one spell out what may take place in such a case, especially when it is truly a matter of an extreme emergency and of how it is to be eliminated." Ibid. at 6-7.

${ }^{8} \mathrm{Ibid}$. at 5 . Conversely, the emergency reveals who in fact the sovereign is $(\mathrm{Ibid}$. at 6,13$)$.

${ }^{9} \mathrm{Ibid}$. at 12.

${ }^{10}$ Posner and Vermeule take up this point in Eric A Posner \& Adrian Vermeule, The Executive Unbound (Oxford, UK: Oxford University Press, 2010) at 32-33 [Unbound].
} 
whatever is necessary to bring the crisis to an end. Executive discretion cannot be constrained by law.

Schmitt's work, though extreme and unsettling for most legal scholars, seemed to offer an explanation for the sweeping executive action taken by the United States in the wake of the 9/11 terrorist attacks. The President declared a state of emergency, and authorized indefinite detention and 'advanced interrogation tactics' at Guantanamo Bay, as well as warrantless spying, all initially through unilateral executive action. ${ }^{11}$ In addition, Congress delegated the President sweeping authority to use "all necessary and appropriate force" against terrorism. ${ }^{12}$ As we shall later see, the United States Supreme Court was, at least initially, extremely deferential to emergency actions that deviated from ordinary constitutional requirements. The challenge for legal scholars writing about national security after 9/11 was to show that the American emergency response was not, as Schmitt would have claimed, inevitable. They sought to show that Schmitt was wrong in his assumptions about law and its ability to constrain emergency power. ${ }^{13}$

Schmitt's challenge - the challenge to show that emergencies can be governed by law is the backdrop against which the contemporary emergency powers debates take place. ${ }^{14}$ This is

\footnotetext{
${ }^{11}$ Kent Roach, The 9/11 Effect: Comparative Counter-Terrorism (Cambridge: Cambridge University Press, 2011 ) at 4. These actions were subsequently ratified through legislation. 12 Authorization for the Use of Military Force, Pub L No 107-40, 115 Stat 224 (2001) (US) [AUMF].

${ }^{13}$ David Dyzenhaus, The Constitution of Law: Legality in a Time of Emergency (Cambridge: Cambridge University Press, 2006) at 34-5, 40 [Constitution]; Bruce Ackerman, "The Emergency Constitution” (2004) 113 Yale LJ 1029 [Ackerman]; Sanford Levinson, "Constitutional Norms in a State of Permanent Emergency" (2005) 40 Ga L Rev 699 [Levinson].

${ }^{14}$ Law in Times of Crisis, supra note 3 at 163, Thomas Poole, "Constitutional Exceptionalism and the Common Law" (2009) 7 Int'l J Const L 247 at 248 [Poole], Giorgio Agamben, State of Exception, translated by Kevin Attell (Chicago and London: The University of Chicago Press, 2005). If anything, constitutional law scholars have relaxed the threshold for what constitutes an emergency. Schmitt focused on a truly existential threat, but the prevalence of Schmitt's challenge in the post-9/11 literature suggests that something less than an existential threat can constitute an emergency, given that, as dramatic as terror attacks of the last two decades have been,
} 
a challenge of the first order. Simply put, there is no point in debating the appropriateness of particular legal measures in times of crisis if Schmitt is correct that emergency powers are inevitably unconstrained by law. Schmitt's challenge, then, lies at the crux of the legal theoretical debate over emergencies. It arises from the fact that emergencies contain two epistemic features: a lack of ex ante knowledge about the specific events that may produce an emergency, and a lack of ex ante knowledge about how to respond to such an unforeseen event. These features can arise when the state faces a political or national security threat-as Schmitt claims - but, as we will see, these features inhere in environmental issues as well.

\section{B. The Environmental Emergency}

The argument that these two epistemic features inhere in environmental issues follows from the current scientific understanding of ecological systems as complex, adaptive systems. Ecosystems are comprised of myriad intricate and indeterminate relationships between humans, plants, animals, and the abiotic components of the environment, such as the climate. These relationships are themselves adaptive, or changing over time, which makes predicting the impacts of our actions on the environment extremely difficult. Complex, adaptive systems are characterized by two phenomena. The first is indeterminacy, ${ }^{15}$ or the fact that ecosystems are comprised of non-linear dynamics, which are vastly different than the direct, linear and causal linkages that can be determined in a scientific laboratory. ${ }^{16}$ The second phenomenon is the

they have not been existential threats. Furthermore, the basic problem that emergencies pose for law can be traced back to John Locke, Two Treatises of Government (London, 1764) at ss 159-160. Oren Gross, "Chaos and Rules: Should Responses to Violent Crises Always Be Constitutional?” (2003) 112 Yale LJ 1011 ["Chaos"],offers a nice overview of how a core understanding of the emergency permeates political and legal theory.

${ }^{15}$ Brian Wynne, "Uncertainty and Environmental Learning" (1992) 2 Global Envtl Change 111 at 114 ; Frank Fischer, "Environmental Regulation and Risk-Benefit Analysis: From Technical to Deliberative Policy Making" R Paehlke, D Torgerson eds, Managing Leviathan: Environmental Politics and the Administrative State 2d ed (Peterborough, Ont: Broadview Press, 2005) 59 at 74.

${ }^{16}$ Crawford S Holling, "Resilience and Stability of Ecological Systems" (1973) 4 Ann Rev of Ecology and Systematics 1; Karin Mickelson \& William E Rees, "The Environment: Ecological and Ethical Dimensions” in EL 
relatively high chance of an extreme event, or tipping point, that dramatically and unexpectedly changes the dynamics of the system. Extreme events-such as large hurricanes, earthquakes or pest outbreaks - occur with surprising frequency, ${ }^{17}$ and can disrupt the system such that it does not return to its prior state. ${ }^{18}$ This second feature, the extreme event, is an emergency in a conventional sense. But it is the combination of the two features of indeterminacy and the possibility of catastrophe that give rise to the conceptual argument that all environmental issues constitute an ongoing emergency from the perspective of the problem that they pose for law.

The concept of the environmental emergency has a special affinity with climate change, an environmental issue of both global and existential proportion. ${ }^{19}$ The current trajectory of greenhouse gas emissions is projected, by the end of the century, to result in extreme risks to all biological processes on the planet. ${ }^{20}$ And while the general phenomenon of climate change is now foreseeable, along with some of its consequences - the rise of sea levels and severe heat waves that directly endanger human lives, for example ${ }^{21}$ - most of its specific impacts remain unpredictable. ${ }^{22}$ For example, polar ice caps are melting at a rate that far exceeds earlier

\footnotetext{
Hughes, AR Lucas, \& WA Tilleman, eds, Environmental Law and Policy 3d ed (Toronto: Emond Montgomery Publications Ltd, 2003) 1 at 9 [Mickelson \& Rees]

17 Daniel A Farber, "Probabilities Behaving Badly: Complexity Theory and Environmental Uncertainty" (2003) 37:1 UC Davis L Rev 145 at 153-4.

${ }^{18}$ Mickelson \& Rees, supra note 16 at 10. The account of the environmental emergency offered here shares several features with Beck's influential thesis of the risk society. Beck's risk society is based on the idea that we now face novel risks which are global in nature, escape perception until its too late, and are the product of modernization. Beck argues that these risks have come to be a "domination force in history and society." Ulrich Beck, Risk Society, translated by Mark Ritter (London: Sage Publications, 1992) at $21-22$ [Beck].

19 Anthony Giddens, The Politics of Climate Change 2d ed, (Cambridge: Polity Press, 2011) at 1.

${ }^{20}$ Intergovernmental Panel on Climate Change, Climate Change 2014: Impacts, Adaption, and Vulnerability Summary for Policy Makers at 13-14 [IPCC]. A 4-5 degree Celsius increase above pre-industrial levels, the current IPCC estimate for the end of this century if emissions continue unabated.

${ }^{21}$ Ibid. at 13.

${ }^{22}$ Indeed, it seems that the IPCC's reports are less and less confident in the ability to predict the impacts of climate change: Fred Pearse, "UN Climate Report is Cautious on Making Specific Predictions" Yale Environment 360 (24 March 2014) online: Yale Environment 360

<http://e360.yale.edu/feature/un_climate_report_is_cautious_on_making_specific_predictions/2750/>.
} 
scientific predictions, ${ }^{23}$ and ocean acidification is a byproduct of carbon dioxide absorption in the seas with potentially serious but currently unknown consequences for marine ecosystems. ${ }^{24}$ Indeed, the greater concern arising from climate change is that we have fundamentally altered our ecological support systems in highly significant but unknown ways. ${ }^{25}$ This means that it may be difficult to specify in advance what specific actions should be taken to adapt to a changing climate and prepare for its myriad unknown consequences. ${ }^{26}$ Indeed, it is often essential, once these specific consequences become known, that we take immediate action to avoid further catastrophic or irreversible harm.

One of these specific impacts is currently unfolding in Western Canadian forests. These forests are experiencing the second largest insect epidemic in North American history. ${ }^{27}$ The mountain pine beetle has decimated the lodgepole pine population across the province of British Columbia. ${ }^{28}$ At times the beetles travelled in such density that they could be seen as a light drizzle on weather radar, and, as illustrated in the epigraph, "fell like rain out of the sky." ${ }^{99}$ The mountain pine beetle now covers an unprecedented range, extending well into the neighbouring province of Alberta. Moreover, having overrun its historic host, the beetle has

\footnotetext{
${ }^{23}$ Loren Morello and Climate Wire, "Polar Ice Sheets Melting Faster than Predicted" Scientific American (9 Mar 2011), online: Scientific American <http://www.scientificamerican.com/article/polar-ice-sheets-melting-fasterthan-predicted/>.

${ }^{24}$ IPCC, supra note 20 at 17

${ }^{25} \mathrm{Ibid}$. at 6 ("Impacts from recent climate-related extremes, such as heat waves, droughts, floods, cyclones, and wildfires, reveal significant vulnerability and exposure of some ecosystems and many human systems to current climate variability (very high confidence).") and at 11 ("Uncertainties about future vulnerability, exposure, and responses of interlinked human and natural systems are large (high confidence).")

${ }^{26}$ This should not be mistaken as an excuse for inaction as it is always possible to put in place measures based on the best available evidence. The point is simply that situations will arise that were unforeseeable. Ibid. at 9 ("Responding to climate-related risks involves decision making in a changing world, with continuing uncertainty about the severity and timing of climate-change impacts and with limits to the effectiveness of adaptation (high confidence).")

${ }_{27}$ Empire, supra note 2 at 55.

${ }^{28}$ A History of the Battle Against the Mountain Pine Beetle (Government of British Columbia, 2012) at 3, online $<$ http://www.for.gov.bc.ca/hfp/mountain_pine_beetle/Pine\%20Beetle\%20Response\%20Brief\%20History\%20May \%2023\%202012.pdf > [History of MPB].

${ }^{29}$ Empire, supra note 2 at 74.
} 
begun to attack new tree species for the first time, making the entire pan-Canadian boreal forest susceptible to attack. ${ }^{30}$ The epidemic is a natural disaster, albeit not a conventional one, analogized by one author to a slow-moving tsunami. ${ }^{31}$

The epidemic will wreck havoc on the British Columbia forest industry, the province's primary natural resource industry. It has killed vast areas of forest in the interior of British Columbia, turning the landscape red, then grey as the attacked trees die. The result has been a short-term boom of available timber which needs to be logged before it rots. ${ }^{32}$ Even still, the beetle is out-logging the loggers, ${ }^{33}$ meaning that around half of all lodgepole pine, deliberately managed for long-term harvesting, will not be available for harvest in 10 to 50 years time. ${ }^{34}$

The possibility of catastrophe was not considered by decision-makers responsible for decades of forest management decisions preceding the beetle epidemic. ${ }^{35}$ Mountain pine beetle

\footnotetext{
${ }^{30}$ Ben Parfitt, Battling the Beetle: Taking Action to Restore British Columbia's Interior Forests (Vancouver: Canadian Centre for Policy Alternatives, 2005) at 16 [Battling].

${ }^{31}$ Empire, supra note 2 at Chapter 3 "The Lodgepole Tsunami," and at 74 (quoting the manager of a beetle action coalition, "It's not something you've ever seen before. It's like a tsunami that takes twenty-five years instead of two seconds.").

32 This is known as the timber's "shelf-life" and is typically in the 10-15 year range, depending on local conditions: Forest Practices Board, Evaluating Mountain Pine Beetle Management in British Columbia (Victoria: Forest Practices Board, 2004) at 16 [FPB Evaluating]. Beetle-killed timber is still commercially viable — the wood takes on a bluish tinge, but tests the same as 'green' timber in terms of strength and durability: Alex Ferguson, "Challenges and Solutions - An Industry Perspective” in TL Shore et al eds, Mountain Pine Beetle Symposium: Challenges and Solutions October 30-31 2003 (Victoria: Pacific Forestry Centre, 2003) 76 at 77, online: $<$ https://www.for.gov.bc.ca/hfd/library/mpb/bib93473.pdf $>$.

${ }^{33}$ In some areas, by as much as 23 times: Empire, supra note 2 at 62.

${ }^{34}$ Harry Nelson, "Does A Crisis Matter? Forest Policy Responses to the Mountain Pine Beetle Epidemic in British Columbia" (2007) 55 Can J of Ag Econ 459 at 463 [Nelson]; John Pousette \& Chris Hawkins, "An Assessment of Critical Assumptions Supporting the Timber Supply Modelling for Mountain-Pine-Beetle-Induced Allowable Annual Cut Uplift in the Prince George Timber Supply Area" (2006) $7 \mathrm{~J}$ of Ecosystems and Management 93 at 94. 35 The unforeseeability of this epidemic, in part, arises from the fact that forest management decisions were not initially being made with respect to lodgepole pine, which only received commercial interest in the 1970 . The beetle epidemic was therefore a by-product of the increase in mature lodgepole pine, which itself was a by-product of forest management decisions with different focuses: Roger J Whitehead, Les Safranyik and Terry L Shore, "Preventative Management" in Les Safranyik and Bill Wilson eds, The Mountain Pine Beetle: A Synthesis of Biology, Management and Impacts on Lodgepole Pine (Victoria: Pacific Forestry Centre, 2006) 173 at 186. Nor was this kind of epidemic contemplated by industry. No forestry company had a management plan or lease provision accounting for beetle outbreaks: Empire, supra note 2 at 52.
} 
outbreaks are a regular occurrence in forests dominated by lodgepole pine. ${ }^{36}$ But not on this scale. Though we now know that the combination of fire suppression ${ }^{37}$ and climate change ${ }^{38}$ were the main drivers of the epidemic, the complexity of ecological relationships makes it extremely difficult (if not impossible) to know in advance how disparate forest management decisions may impact the beetle's long-term population dynamics, let alone predict how those decisions might intersect with climate change. Moreover, the ongoing dynamics of the beetle continue to defy prediction. “[T] $[\mathrm{T}$ he pine beetle did everything the experts said it couldn't do: it flew over mountains, it invaded northern forests, it attacked spruce trees, and it wiped out pine plantations not much thicker in diameter than baseball bats." 39

Indeterminacy poses a serious problem for environmental decision-making. It means that our understanding of the problem is necessarily incomplete and that our ability to predict the effects of our decisions on the environment is limited. ${ }^{40}$ Complex, adaptive systems are comprised of relationships so intricate and dynamic as to be incompressible. The "simplest model is the process itself [and $t$ ] he only way to determine the future of the system is to run it:

\footnotetext{
${ }^{36}$ FPB Evaluating, supra note 32 at 9.

${ }^{37}$ Fire suppression tripled the area covered by mature lodgepole pine: Kim McGarrity \& George Hoberg, The Beetle Challenge: An Overview of the Mountain Pine Beetle Epidemic and its Implications (Vancouver: Forest Policy Resources, University of British Columbia, 2005) at 4. Fire suppression is a basic, and uncontroversial forest management practice for maintaining timber yield: History of MPB, supra note 28 at 2 . The importance of fire suppression in forestry management can be seen from early Royal Commissions on the state of BC's forests: Fred J Fulton, Royal Commission of Inquiry on Timber and Forestry 1909-1910 (Victoria: Government of British Columbia, 1910) at 60 [Fulton Commission]; Gordon Sloan, The Forest Resources of British Columbia (Victoria: Government of British Columbia, 1945) at 129 [Sloan Commission 1945]; Gordon Sloan, The Forest Resources of British Columbia (Victoria: Government of British Columbia, 1956) at 245 [Sloan Commission 1956].

${ }^{38}$ Historically, mountain pine beetle populations were kept in check by very cold weather - typically minus $35^{\circ}$ Celsius for several days — which kills the beetle larvae: History of the MPB, supra note 28 at 2. This type of weather event has not occurred in the British Columbia interior since the winter of 1995/96. Ibid. Above average summer temperatures have exacerbated the problem by stressing the trees and making them more susceptible to attack: Ibid.

${ }^{39}$ Empire, supra note 2 at 57.

40 JB Ruhl, "The Pardy-Ruhl Dialogue on Ecosystem Management, Part IV: Narrowing and Sharpening the Questions" (2007) 24 Pace Envtl L Rev 25 at 28 [Ruhl].
} 
there are no shortcuts." ${ }^{41}$ It is therefore very difficult to accurately forecast the future. Indeed, even when ecological relationships are well understood, the most minuscule errors in measurement can cause drastically inaccurate predictions because of the non-linear dynamics of the system. ${ }^{4 \cdot 2}$ Moreover, indeterminacy means that both our understanding of the problem and the problem itself are constantly evolving. Environmental decisions are often made in a "noanalogue" state, ${ }^{43}$ where past decisions are of limited usefulness because they were influenced by a host of complex interactions that have changed over time. For example, fire suppression decisions in the first half of the 20th century were not predictive of possible effects on the mountain pine beetle in the latter half of the century because never before had these management decisions intersected with climate change.

This incomplete understanding poses an additional challenge because complex, adaptive systems also contain the relatively high probability of extreme events, ${ }^{44}$ which are also not always knowable in advance. Disturbances of complex, adaptive systems are not accurately described by simplistic bell curve distributions, in which the probability of severe events decays rapidly, effectively allowing decision makers to ignore the possibility of extreme events that are "off the chart." Rather, complex, adaptive systems are characterized by "fat tail probabilities," 45 meaning that extreme, even catastrophic events, occur with surprising frequency. Decisionmakers cannot justifiably disregard the possibility of such extreme events. ${ }^{46}$

\footnotetext{
${ }^{41}$ Jean-Pierre Dupuy, "Complexity and Uncertainty A Prudential Approach to Nanotechnology" in Health and Consumer Protection Directorate General of the European Commission, Nanotechnologies: A Preliminary Risk Analysis on the Basis of a Workshop Organized in Brussels on 1-2 March 2004 (European Commission, 2004$) 71$ at 81.

${ }^{42}$ Farber, supra note 17 at 153; Mickelson and Rees, supra note 16 at 9.

${ }^{43}$ Arild Underdal, "Complexity and Challenges of Long-Term Environmental Governance” (2010) 20 Global Envtl Change 386 at 388.

${ }^{44}$ Farber, supra note 17 at 152-5; Mickelson and Rees, supra note 16 at 9-10.

${ }^{45}$ Farber, supra note 17 at 155.

${ }^{46}$ See for example, Douglas Kysar's excellent analysis of the risk assessment for hurricane protection that preceded Hurricane Katrina, which eliminated one of the most extreme hurricanes from the analysis because they
} 
The current mountain pine beetle is just that extreme event: a beetle epidemic so severe that it could not have been predicted by looking at the historical record of mountain pine beetle outbreaks, or indeed any prior insect outbreak in Canada. ${ }^{47}$ It is the unavoidable nasty surprise; ${ }^{48}$ the unexpected outcome that we did not even know to look for when deciding to implement widespread fire suppression. The mountain pine beetle epidemic illustrates that, even when we have a decades-old approach to a problem with a seemingly sound grasp of its dimensions, extreme unforeseeable events still occur. Our necessarily incomplete understanding of ecological systems means that surprises - sometimes catastrophic surprises — are unavoidable.

\section{Redefining Environmental Law}

Our understanding of ecological systems as complex, adaptive systems means that the epistemic features of emergencies are inherent within all environmental issues. While it is certainly not the case that all environmental issues contain the possibility of an extreme event or catastrophe, our inability to distinguish in advance the ones that contain this possibility from the ones that do not justifies viewing all environmental issues from this perspective. It is not possible to "carve out irreversible or catastrophic risks for special treatment," 49 since, as the beetle example illustrates, we cannot reliably identify these in advance. This means that while, on its face the beetle epidemic may seem an exceptional environmental issue, the necessarily

were statistical outliers: Douglas A Kysar, Regulating from Nowhere: Environmental Law and the Search for Objectivity (New Haven: Yale University Press, 2010) at 77 [Regulating from Nowhere].

${ }^{47}$ Bill Wilson, "An Overview of the Mountain Pine Beetle Initiative" Terry L Shore, J E Brooks, J E Stone eds, Mountain Pine Beetle Symposium: Challenges and Solutions (Kelowna: Natural Resources Canada, 2003 ) 3 (noting that by 2002, a full decade before its peak, the epidemic already rivaled any forest pest in recorded North American history).

48 Farber, supra note 17 at 167.

49 Douglas A Kysar, "It Might Have Been: Risk, Precaution and Opportunity Costs" (2006) 22 J Land Use \& Envtl L 1 at 22 [Kysar 'Risk']. See also Beck, supra note 18 at 78-9. 
incomplete state of our knowledge requires the recognition that even gradual, low-level or chronic environmental harm may eventually reach its own tipping point resulting in an unforeseen, extreme event. Moreover, the dynamics of complex systems mean that some of the most pernicious features of catastrophes, such as their irreversibility, "should be expected to characterize all decision nodes within complex adaptive systems." 50

In other words, what may at the time of their making seem like trivial or benign regulatory decisions, can in fact have irreversible environmental effects even if their full impacts do not materialize until well into the future, long past when anything can be done about it. Each environmental issue can therefore be understood as an "emergency in miniature", ${ }^{51}$ in which decisions must be taken under conditions of uncertainty and the possibility that this decision will be the one that triggers the catastrophe cannot be eliminated in advance. In this way, the concept of the environmental emergency reflects our current understanding of ecological systems, irrespective of the actual probability of a catastrophe or whether, in the end, it in fact occurs. It is our epistemic inability to distinguish benign from catastrophic policy choices that justifies viewing all relevant events and policies through the prism of the emergency paradigm.

By building on this understanding of complex, adaptive ecological systems, the environmental emergency underscores the fact that environmental decisions are always taken under conditions of uncertainty. Even where environmental issues have received abundant scientific attention, unforeseen dimensions still arise. Daniel Bodansky argues that "many of today's most serious problems were unanticipated and would probably not have been prevented

\footnotetext{
50 Ibid. at 22 .

${ }^{51}$ Constitution, supra note 13 at 60.
} 
even if regulators had chosen the cautious approach." ${ }^{52}$ In other words, the challenge for environmental law is not only acquiring and incorporating better environmental science, but coping with the complex features inherent in the issues themselves. ${ }^{53}$ The challenge for legality is to understand how the rule of law can operate under conditions of such profound complexity.

\section{Part II. The Dualist Fiction}

Since environmental issues are best understood as an ongoing emergency, the next task is to understand the precise nature of the problem that emergencies pose for law. We saw in Part I that Schmitt both defines the emergency and makes specific assumptions about law. In particular, he equates law with relatively determinative rules set down in advance by the legislature. ${ }^{54}$ I follow David Dyzenhaus and others in referring to this as the formal conception of the rule of law, because it hinges on a formal allocation of power between the branches of government. ${ }^{55}$ We will return to the formal conception in detail in Part III, but here I argue that, for those who subscribe to a formal conception of the rule of law, there are only two responses to the emergency: the extra-legal approach or accommodation. In brief, the extralegal approach permits public officials to act in contravention of the law in order to respond to the emergency. In contrast, under the accommodation approach, emergencies are

\footnotetext{
${ }^{52}$ Daniel Bodansky, "Scientific Uncertainty and the Precautionary Principle" (1991) 33 Environment: Science and Policy for Sustainable Development 4 at 43 . He observes that CFCs and DDT were subject to rigorous scientific testing but were found to be environmentally benign. The problem was not bad science, "but that scientists did not test for the right types of environmental impacts. ...Extensive studies were done on the acute toxicity of DDT, but not on its chronic effects."

${ }^{53}$ Douglas A Kysar, "Climate Change, Cultural Transformation, and Comprehensive Rationality" (2004) 31 BC Envtl Aff L Rev 555 at 565 [Kysar 'Climate Change']; Frank Fischer, "Environmental Regulation and RiskBenefit Analysis: From Technical to Deliberative Policy Making" In R Paehlke, D Torgerson eds, Managing Leviathan: Environmental Politics and the Administrative State 2d ed (Toronto: Broadview Press, 2005 ) 59 at 63 ("In short, scientific work had expanded the realm of what was unknown far more rapidly than it had the realm of the known.")

54 William E Scheuerman, "Carl Schmitt's Critique of Liberal Constitutionalism" (1996) 58 The Review of Politics 299 at 314-315; Dyzenhaus Constitution, supra note 13 at 61.

55 David Dyzenhaus \& Evan Fox-Decent, "Rethinking the Process/Substance Distinction: Baker v Canada" (2001) 51 UTLJ 193 at 197-205 ["Rethinking"]; Martin Loughlin, "Procedural Fairness: A Study of the Crisis in Administrative Law Theory" (1978) 28 UTLJ 215 [Loughlin]; Geneviève Cartier, "Procedural Fairness in Legislative Functions: The End of Judicial Abstinence?” (2003) 53 UTLJ 217 [Cartier].
} 
governed by the rule of law, albeit a thinner conception of the rule of law that accepts the need for flexibility in times of crisis. I argue that both these approaches rest on a "dualist fiction," which construes emergencies as temporary and exceptional events. It thus mistakenly assumes that we can maintain dual legal orders: i.e., one that governs ordinary times and one that governs emergencies. We will see that this assumption cannot be sustained, and so the formal conception of the rule of law fails to meet Schmitt's challenge.

\section{A. The Extra-Legal Approach}

The persuasiveness of Schmitt's argument is most apparent from the emergent literature advocating for an extra-legal approach to emergency powers. Oren Gross offers the most comprehensive account of the extra-legal approach. ${ }^{56}$ Gross follows Schmitt in his open acknowledgement that emergencies cannot be governed by law. Gross concedes that their unforeseeable and extreme nature necessitates exceptional state action. ${ }^{57} \mathrm{He}$ supports his argument with a detailed historical account of how constitutional commitments do not seem to prevent governments from taking these emergency response actions. ${ }^{58}$ But, in contrast to Schmitt, Gross argues that permitting extra-legal measures is the best hope of preserving a long-term commitment to the rule of law. Since it seems that public officials will take exceptional actions notwithstanding legal constraints, Gross argues, we should permit them to do so, provided that they act openly and for the purpose of the public good. ${ }^{59}$ Gross reasons

\footnotetext{
${ }^{56}$ Chaos, supra note 14. See also Mark Tushnet, "Emergencies and the Idea of Constitutionalism" Mark Tushnet ed, The Constitution in Wartime (Durham \& London: Duke University Press, 2005) 39, discussed in this section as well [Tushnet]. See also Clement Fatovic, Outside the Law: Emergency and Executive Power (Baltimore: John Hopkins University Press, 2009), Nomi C Lazar, States of Emergency in Liberal Democracies (New York: Cambridge University Press, 2009) and Bonnie Honig, Emergency Politics: Paradox, Law, Democracy (Princeton: Princeton University Press, 2009) reviewed in David Dyzenhaus, "Emergency, Liberalism, and the State" (2011) 9 Perspectives on Politics 69 [Dyzenhaus "Liberalism"].

${ }^{57}$ Chaos, supra note 14 at 1097.

${ }^{58} \mathrm{Ibid}$.

${ }^{59} \mathrm{Ibid}$.
} 
that this keeps the rule of law intact; we do not legitimize these exceptional actions as legal. He worries that legally authorized emergency powers will normalize. Over time, legal emergency responses will seep into the ordinary legal regime and weaken ordinary rule-of-law commitments. The extra-legal approach, in contrast, has the virtue of transparency. Emergency measures, according to Gross, are seen for what they really are-extreme actions driven by necessity. ${ }^{60}$

In practice, an extra-legal approach means emergency powers are solely within the discretion of individual public officials. These officials must make the determination of whether an illegal action-e.g. torture-is necessary. Gross argues that public officials facing such a choice will be regulated by their "ethic of responsibility." ${ }^{1}$ By this he means their desire to protect their institutions and citizens against threats and accept the consequences, whatever they may be, of their actions. Indeed, Gross pins much on the uncertainty of potential consequences. Since public officials do not know whether the public will ratify the extra-legal action (e.g. by their legislative representatives passing an Act of Indemnity) or repudiate it (e.g. criminal prosecution), he presumes overzealous extralegality will be held in check.

A second proponent of the extra-legal approach, Mark Tushnet, would go even further. Tushnet argues that Gross' approach is hardly "extra-legal” because it relies so heavily on ex post legal sanctions. Tushnet would strip the courts of any supervisory authority. Tushnet's

\footnotetext{
${ }^{60}$ Tushnet, supra note 56 also endorses a version of the extra-legal approach. " $[\mathrm{I}] \mathrm{t}$ is better," Tushnet reasons, “to have emergency powers exercised in an extraconstitutional way, so that everyone understands that the actions are extraordinary, than to have the actions rationalized away as consistent with the Constitution and thereby normalized." (at 61).

${ }^{61}$ Chaos, supra note 14 . at 1108-9.
} 
view is that "extra-constitutional powers are neither legal ...nor illegal" 62 and therefore cannot be subject to review in the courts.

Both Tushnet and Gross' arguments hinge entirely on an assumption that emergencies are truly exceptional events that can be readily distinguished from ordinary regulatory problems faced by the state. ${ }^{63}$ The terms of Schmitt's challenge preclude them from identifying in advance the kinds of situations that will warrant extra-legal action. Such action is necessarily an individual determination in the discretion of the public official. Gross, for his part, offers the classic example of the ticking timebomb scenario that might lead an official to commit torture to obtain vital information to locate and diffuse the bomb. ${ }^{64}$ Tushnet offers the counter-example of the open-ended "war on terror." He warns that “[s] uspending legality during a time-limited war is one thing. Suspending it during a more or less permanent condition is quite another. The latter is the end of the rule of law itself." ${ }^{55}$ This lack of specificity and Tushnet's warning reveals that this is a precarious dualist order indeed.

Critics have pointed to two highly dubious assumptions on which Gross and Tushnet rely. As we have seen, the extra-legal approach requires public officials to act with candour. But why would they? The prospect of potentially severe repercussions - that the official will be personally liable-would seem sufficient to drive extra-legal actions out of public sight, not into it. A second flaw is that the same influences that cause legal regulation of emergency powers to normalize would seemingly apply to extra-legal powers. Gross has documented the many ways in which exceptional powers are rationalized and eventually creep into the ordinary

\footnotetext{
62 Tushnet, supra note 56 at 46,50 .

${ }^{63}$ Poole, supra note 14 at 272 (the model "stands or falls by the suitability of its basic binary structure").

${ }^{64}$ Chaos, supra note 14 at 1097-8.

65 Tushnet, supra note 5656 at 45.
} 
legal order. ${ }^{66}$ For example, he notes that emergency powers can become effectively permanent when a state is faced with repeated threats. In other cases, he observes that emergency powers exercised abroad have a way of migrating across borders to be adopted at home. In other words, emergency measures can gain political currency that undermines attempts to clearly maintain a dual legal order. When this insight is applied to Gross' argument it seems that, once one extralegal action is politically ratified, it is likely that public officials would be able to correctly expect that the public would ratify subsequent emergency actions as well. ${ }^{67}$

David Dyzenhaus goes further and critiques Gross' equivocation over the possible source of extra-legal powers. At times Gross seems to suggest that the power to act extralegally may be located within the constitutional order itself. ${ }^{68}$ Dyzenhaus argues that, by acknowledging that officials have the legal power to violate the law, Gross eliminates any legal basis on which we can constrain executive discretion to prevent its conversion into an unlimited power. ${ }^{69}$ In other words, Gross' move means there is no conceptual basis on which to make the dualist fiction real. There is no way to impose legal constraints on the exercise of discretion once we accept that it is permissible to exercise discretion in violation of the law.

\section{B. The Accommodation Approach}

These critiques of the extra-legal approach seem to have some traction. The extra-legal approach has not been the dominant response to emergency powers. Far more prevalent is the

\footnotetext{
${ }^{66}$ Chaos, supra note 14 at 1073-1077.

${ }^{67}$ Daniel H Cole, "Judging the Next Emergency: Judicial Review and Individual Rights in Times of Crisis" (2003) 101 Michigan L Rev 2565 at 2589; Dyzenhaus "Constitution," supra note 13 at 52.

${ }^{68}$ Oren Gross, "Extra-legality and the ethic of political responsibility" Victor V Ramraj ed, Emergencies and the Limits of Legality (Cambridge: Cambridge Univ Press, 2008) 60 at 97.

${ }^{69}$ Dyzenhaus “Constitution," supra note 13 at 52-53.
} 
attempt to "accommodate" 70 emergencies within legal order. The accommodation approach attempts to subject emergencies to some legal constraints, even if we have to concede that these constraints are less rigorous than in ordinary times. Dyzenhaus attributes the accommodation approach to the "compulsion of legality." ${ }^{71}$ In contrast to Gross' assumption of candour, Dyzenhaus argues that public officials will seek to justify their actions as having legal warrant, however tenuous that warrant may be.

The paradigmatic example of the accommodation approach is the Roman constitutional dictatorship, ${ }^{72}$ which provided for the temporary appointment of a constitutional dictator solely for the purpose of bringing an emergency to an end. The constitutional dictator enjoyed nearly unconstrained substantive decision-making power, subject only to his purpose of ending the crisis and preserving, not altering, the ordinary constitution. However, he was still subject to procedural constitutional norms. ${ }^{73}$ The Roman constitution provided for specific appointment procedures for the dictator. ${ }^{74}$ Importantly, the constitution also separated the powers of declaring a state of emergency, which was retained by the elected senate, and responding to the emergency, which was the mandate of the dictator. ${ }^{75}$ And the dictator was subject to a strict six-month term limit and an obligation to resign when the emergency had come to an end. ${ }^{76}$

\footnotetext{
${ }^{70}$ Eric A Posner \& Adrian Vermeule, "Accommodating Emergencies" (2003) Stanford Law Review 605; Law in Times of Crisis, supra note 3 at Chapter 1.

${ }^{71}$ David Dyzenhaus, "Cycles of Legality in Emergency Times" (2007) 18 Public L Rev 165 at 167 [Dyzenhaus, Cycles of Legality]. Dyzenhaus gives as an example Dershowitz's advocacy of torture warrants: Alan M Dershowitz, Why Terrorism Works: Understanding the Threat, Responding to the Challenge (New Haven: Yale University Press, 2002). See also William E Scheuerman, "Survey Article: Emergency Powers and the Rule of Law After 9/11" (2006) 14 J of Political Philosophy 61 at 72.

72 John Ferejohn \& P Pasquino, "The Law of Exception: A Typology of Emergency Powers" (2004) 2 Int'l J Const L 210 at 211 ["Typology"] ("Modern emergencies are, to a greater or lesser extent, modeled on the ancient model of the Roman dictatorship.")

${ }^{73}$ Clinton Rossiter, Constitutional Dictatorship: Crisis Government in the Modern Democracies (New Brunswick: Transaction Publishers, 2002) at 19-5.

${ }^{74} \mathrm{Ibid}$. at 20.

${ }^{75}$ Ibid.

${ }^{76} \mathrm{Ibid}$. at 23.
} 
The Roman constitutional dictatorship thus created a separate regime for emergency powers, one embedded within legal order but subject to distinct and diminished rule-of-law requirements.

The constitutional dictatorship is not a legal antiquity. Prominent constitutional law scholar Bruce Ackerman attempted to rekindle the constitutional dictatorship in his post-9/11 proposal for an "Emergency Constitution."77 Ackerman's proposal, in fact not a constitution but a framework statute, concedes the need for exceptional Presidential powers to respond to crises such as the terrorist attacks of 9/11.78 But Ackerman's proposal would require the President to obtain periodic legislative renewal for exceptional powers, by increasing super-legislative majorities. ${ }^{79}$ Canada's not-so-distant War Measures Act, is another example of a constitutional dictatorship, of sorts. It was properly enacted and constitutionally valid (at the time) ${ }^{80}$ legislation that delegated unfettered discretion to the executive to respond to a crisis. The $W a r$ Measures $A c t^{81}$ has since been replaced by the Emergencies Act, ${ }^{82}$ yet another attempt to accommodate the need for exceptional powers within the legal order, albeit in a more procedurally circumscribed fashion. All three examples illustrate an attempt to create a dual

\footnotetext{
${ }^{77}$ Ackerman's proposal draws extensively on Clinton Rossiter's influential survey of emergency powers and argument for a constitutional dictatorship, again modelled on the Roman dictatorship: Ackerman, supra note 13.

$78 \mathrm{Ibid}$. at 1038 .

${ }^{79} \mathrm{Ibid}$. at $1047 \mathrm{ff}$.

80 The Court upheld the exercise of powers because they were legal, that is authorized by validly enacted legislation: Gagnon and Vallières v. The Queen (1971), 14 C.R.N.S. 321 (Que. C.A.). But see Herbert Marx, "The Apprehended Insurrection of October 1970 and the Judicial Function" (1972) 7 UBCL Rev 55 and J N Lyon, "Constitutional Validity of Sections 3 and 4 of the Public Order Regulations, 1970" (1972) 18 McGill LJ 136 (on the Act's potential violation of the division of powers between federal and provincial governments, and the ways in which the courts could have asserted a much stronger role).

${ }^{81}$ Supra note 4.

${ }^{82}$ Ibid.
} 
legal order: one set of legal rules for ordinary times, and a separate set invoked in times of crisis. $^{83}$

Dyzenhaus argues that these emergency powers are "legal black holes," 84 that is a legislative attempt to create a sphere of action that is not governed by law. In other words, the legislature declares that any action taken under the statute is prospectively legalized. The problem with legal black holes, as Schmitt pointed out, is that there is in fact no way to confine them. Interestingly, Schmitt initially endorsed the constitutional dictatorship but he quickly changed his mind. He argued there is no way to make a dictatorship constitutional because the unforeseeable and extreme nature of the emergency means that it cannot be subject to binding legal requirements, not even requirements procedural in nature. ${ }^{85}$ Since an emergency might even require suspension of the legal order, it was impossible for law to ensure that a constitutional dictatorship remained temporary. By conceding that it is necessary to suspend the ordinary legal order in favour of a temporary dictatorship, a constitutional dictatorship necessarily concedes that it might be possible to suspend the temporary dictatorship as well.

Ackerman even seems to concede this point. He argues that legislative oversight is necessary because historically the judiciary has not been effective at constraining executive emergency action. ${ }^{86}$ But this raises the problem that ultimately these legislative constraints

\footnotetext{
${ }^{83}$ Gross and Aolain offer a comprehensive account of forms of accommodation: international, constitutional, legislative levels and through judicial interpretation that relaxes ordinary ROL requirements: Law in Times of Crisis, supra note 3 at Chapter 1.

84. Dyzenhaus "Constitution," supra note 13 at 3.

85 This about-face is explored in John P McCormick, "The Dilemma of Dictatorship: Carl Schmitt and Constitutional Emergency Powers" David Dyzenhaus ed, Law as Politics: Carl Schmitt's Critique of Liberalism (Durham \& London: Duke University Press, 1998) 217 at 221-2.

${ }^{86}$ Ackerman, supra note 13 at 1031 ("we cannot rely on judges to manage the panic-driven reactions likely to arise.”) Cole notes that this is curious choice as the historical record suggests that Congress is even more unreliable than the courts and existing emergency legislation sits in the books without any practical influence:
} 
require judicial enforcement, ${ }^{87}$ which leads to the perplexing and circular conclusion that the political checks needed because of judicial weakness must be enforced by the courts. ${ }^{88}$ According to Ackerman's own reasoning, if the executive chose to suspend the emergency constitution (i.e. ignore a failed attempt at legislative re-approval), it is unlikely the courts can be relied on to do anything about it. So while Ackerman's proposal is an explicit attempt to respond to the Schmittian problem of emergencies, ${ }^{89}$ it in fact does no such thing.

The problem that underlies both Gross' extra-legal approach and accommodation is the same. Once we concede that the law permits us to suspend the ordinary legal order in favour of an emergency legal order, we no longer have the legal resources to ensure that the emergency legal order remains temporary and exceptional.

Defenders of the accommodation approach argue that this "badly misconstrues the contemporary danger." 90 As the response to $9 / 11$ in the United States and Canada demonstrates, we are not at any risk of the permanent suspension of legal order. ${ }^{91}$ Instead we face the more insidious problem of rapidly expanding zones of discretionary executive authority. ${ }^{92}$ Put differently, in Canada we no longer face the prospect of the invocation of the War Measure Act, nor do we face a real prospect of its more tailored successor the Emergencies Act. ${ }^{93}$ Instead, the contemporary emergency problem is the proliferation of pockets of executive

Daniel H Cole, "The Priority of Morality: The Emergency Constitution's Blind Spot" (2003) 113 Yale LJ 1753 at 1764-5.

${ }^{87}$ Ackerman, supra note 13 at 1067-8.

${ }^{88}$ Dyzenhaus "Constitution," supra note 13 at 41.

${ }^{89}$ Ackerman, supra note 13 at 1044.

${ }^{90}$ Ian Zuckerman, "One Law for War and Peace? Judicial Review and Emergency Powers between the Norm and the Exception" (2006) 13 Constellations 522 at 528 [Zuckerman]. See also Kim Lane Scheppele, "Small Emergencies" (2005) 40 Ga L Rev 835.

${ }^{91}$ Posner and Vermeule refer to this as "tyrannophobia": Unbound, supra note 10 at Chapter 6.

${ }^{92}$ Zuckerman, supra note 90 at 528.

${ }^{93}$ It has never been invoked. 
discretion within ordinary statutes. In the aftermath of $9 / 11$, Parliament embedded terrorismrelated offences with Canada's Criminal Code. ${ }^{94}$ This means that offences related to the murky concept of terrorism are legally authorized through their placement in ordinary criminal legislation, despite the difficulty of defining the concept of terrorism in advance. ${ }^{95}$ Even more alarming is Canada's new Security of Canada Information Sharing Act. The Act further blurs the concept of "terrorism" to allow the government to collect and share any information on activities that undermine the security of Canada. ${ }^{96}$ Amongst other things, the new legislation permits government departments to collect and share information on any "activities that undermine the security of Canada." 97

This is but a variation of the same problem, a problem that Schmitt long ago diagnosed. He predicted that those committed to the ideal that all executive power should be subjected to the rule of law will be unable to countenance the real nature of emergencies. ${ }^{98}$ Instead, they will attempt to pretend that executive discretion is governed by law-that is, by pre-existing statute, even when it is clear that the executive wields discretionary power. To borrow Dyzenhaus' helpful terminology, we now face the problem of multiple legal black holes and "legal grey holes," which are essentially black holes in disguise. Legal black holes, recall, are attempts by the legislature or the executive to exempt the executive from rule-of-law requirements. When created by the legislature, they are "legislative blank cheques" to the

${ }_{94}$ Criminal Code, RSC 1985, c C-46, Part II.1.

${ }_{95}^{5}$ David Dyzenhaus, "The Permanence of the Temporary - Can Emergency Powers Be Normalized?" R J Daniels, P Macklem, K Roach eds, The Security of Freedom: Essays on Canada's Anti-Terrorism Bill (Toronto: University of Toronto Press, 2001) 21.

${ }^{96}$ Government of Canada, Backgrounder: Security of Canada Information Sharing Act (Jan. 30, 2015), <http://news.gc.ca/web/article-en.do?nid=926879>. Craig Forcese and Kent Roach argue this is a radical departure from past anti-terror approaches and document the numerous ways that this broad definition can be interpreted that gives rise to considerable uncertainty about its future implementation: Craig Forcese \& Kent Roach, "Stumbling Toward Total Information Awareness: The Security of Canada Information Sharing Act" (2015) 12 Can Privacy L Rev 65.

97 Ibid.

98 Scheuerman, supra note 54 especially at 306-8. 
executive. ${ }^{99}$ Legal grey holes create the appearance of legal constraint but are "so insubstantial that they pretty well permit the government to do as it pleases." ${ }^{100}$ An appeals tribunal that simply rubber stamps an executive decision is an example of a legal grey hole. ${ }^{101}$ Schmitt's prediction suggests that those who are committed to the rule of law should be even more comfortable with legal grey holes than with black holes, because they further mask the extent to which a decision is the product of unconstrained discretion.

The American response to 9/11 provides an especially clear example of how Schmitt's critique can play out in practice. In 2004, the United States Supreme Court upheld the executive’s authority to classify and detain US citizens as “enemy combatants" and subject them to a distinct legal process through a system of military tribunals. ${ }^{102}$ The plurality, in line with Schmitt's prediction, deferred to the need for exceptional emergency powers, but was not willing to concede that the executive operated unconstrained by law. Rather, the plurality found legal authorization for detention in the extremely broad language of the Authorization for Use of Military Force (AUMF), ${ }^{103}$ which states that "the President is authorized to use all necessary and appropriate force" against terrorism. ${ }^{104}$ While the plurality is no doubt correct that the open-ended language of "all necessary and appropriate force" could be interpreted to include detention of enemy combatants, the legislation is far from the "explicit congressional authorization" that the plurality claims. ${ }^{105}$ Justice Souter (Ginsburg J. concurring) observed that the legislation "never so much as uses the word detention, and there is no reason to think Congress might have perceived any need to augment Executive power to deal with dangerous

\footnotetext{
99 Dyzenhaus "Constitution", supra note 13 at 50.

100 Ibid. at 42.

101 Ibid. at 3.

${ }^{102}$ Hamdi v Rumsfeld, [2004] 124 S Ct 2633 (US).

103 Ibid. at 518.

${ }^{104}$ AUMF, supra note 12.

${ }^{105}$ Hamdi, supra note 102 at 517.
} 
citizens within the United States, given the well-stocked statutory arsenal of defined criminal offenses covering the gamut of actions that a citizen sympathetic to terrorists might commit."106

The plurality's finding that the AUMF included the authority to create a detention regime cleared the way for the conclusion that the executive also had authority to determine the procedures and therefore the rights accorded to the detainees. The court permitted the creation of a legal grey hole, purportedly governed by the rule of law, but lacking substantive due process rights accorded in ordinary cases. ${ }^{107}$ In other words, the plurality's decision turned the rule of law into a façade of legality, which authorized actions the executive was determined to take in any event. ${ }^{108}$

In short, the accommodation approach also fails Schmitt's challenge. It results in the creation of legal black and grey holes where the exercise of emergency powers is not meaningfully governed by the rule of law. The judiciary's role is reduced to that of a timekeeper, ensuring that powers are not exercised past their expiry date, or the certifier of blank checks, ensuring that legislation is properly enacted. From this perspective, the courts cannot impose substantive constraints on the executive's emergency response because there are none in the legislation to enforce. Accommodating the emergency within legal order allows the executive the best of both worlds. It can exercise essentially unfettered discretion while also claiming to

\footnotetext{
$106 \mathrm{Ibid}$. at 548 .

${ }_{107}$ This argument is also made by Dyzenhaus “Constitution”, supra note 13 at 48-50 and Zuckerman, supra note 90 at 535-6.

108 See Scalia's reasons for legal black hole and Thomas for full Schmitt.
} 
act in accordance with the rule of law. ${ }^{109}$ In short, Schmitt's challenge reveals that in an emergency there is only a façade of legality. Executive discretion is authorized by legislation, but it does not prevent public officials from exercising discretion to achieve illiberal ends.

\section{Part III. The Exceptional Emergency and the Pervasive Problem of}

\section{Discretion}

We have now seen that Schmitt's argument is that the emergency reveals the necessity of unconstrained executive discretion. Any attempt to create a dual legal order - whether extra-legal or accommodating - cannot be sustained because there is no way to confine emergency powers and ensure they remain temporary and exceptional. Embedding emergency powers within ordinary legislation is equally problematic as it only provides a cover - a façade of legality - for discretionary powers. In this Part we will see that Schmitt's challenge is not limited to exceptional emergencies. Rather, it is part of a much more fundamental and systemic critique of liberal constitutionalism, that is, the commitment to subjecting the exercise of all political power to legal authority. As I will explain, Schmitt's challenge can be reframed as the challenge that discretion poses to the formal conception of the rule of law.

Schmitt argues that the emergency fatally undermines the core tenet of liberal constitutionalism; i.e., the subjection to law of all public acts. ${ }^{110}$ Because the operation of legal order hinges on a purely discretionary decision of the sovereign, on his view, it cannot be the

\footnotetext{
109 Dyzenhaus, “Constitution," supra note 13 (on legal black and grey holes); Law in Times of Crisis, supra note 3 at 63; Zuckerman, supra note 90 at 531 (on monism argument); Poole, supra note 14 at 252-8 (reincarinating the prerogative power with a judicial blessing).

110 Scheuerman, supra note 54. See also Dyzenhaus "Liberalism”, supra note 56 at 70 (defining liberal legalism as "all executive action is subject to the control of the rule of law - the control of norms such as due process"); Unbound, supra note 10 at 3 ("the simplest version of liberal legal theory holds that representative legislatures govern and should govern, subject to constitutional constraints, while executive and judicial officials carry out the law.")
} 
case that all political power is subject to legal authorization. But Schmitt's argument is not only limited to this worst-case scenario of the existential threat. Schmitt takes a narrow view of law. By equating law with legislated rules, he does not seem to allow for any kind of discretion in the application of these rules. Dyzenhaus describes Schmitt's perspective as "a kind of naive legal positivism in which 'controlled by law' means that general legal rules determine an outcome so that no human agency or judgment is required to decide what the law says."111 Schmitt's argument about the emergency, therefore, turns on an assumption about the "extralegal" nature of discretion. The emergency is one striking example of the exercise of discretion, but discretion exists in non-exceptional cases as well. Dyzenhaus observes that every discretionary decision, for Schmitt, must be a "mini state of emergency or exception" 112 because the "official...has to make a quasi-sovereign or legislative decision, one that is ultimately unconstrained by legal norms.”113

This is made particularly clear in his work on economic emergencies. Schmitt observed that economic emergencies were also characterized by wide grants of discretionary authority to the executive comparable only to the sweeping authority granted during war or insurrection. ${ }^{114}$ Like the national security emergency, the complex and ever-changing nature of economic problems requires "future-oriented steering" capable of provision only by the executive. ${ }^{115}$ Schmitt observed that legislated rules were based on past experience and could not anticipate the future economic needs of the state. Economic emergencies, then, were the link between the state of emergency and the "growth of far-reaching discretionary executive power and the

\footnotetext{
${ }^{111}$ Dyzenhaus "Liberalism”, supra note 56 at 74-5.

112 Dyzenhaus Constitution, supra note 13 at 60.

113 Ibid.

${ }_{114}$ William E Scheuerman, "The Economic State of Emergency" (2000) 21 Cardozo L Rev 1869 at 1871.

${ }^{115}$ Ibid. at 1887
} 
concomitant decline of elected legislatures." ${ }^{116}$ For Schmitt, existential threats, economic emergencies and everyday executive discretion are all points on the same continuum. In his view, they all reveal the emptiness of liberal constitutionalism, the fact that the executive wields vast and legally unconstrained power.

Contemporary American legal scholars Eric Posner and Adrian Vermeule further draw out these connections in their self-proclaimed "Schmittian" account of the modern administrative state. ${ }^{117}$ Posner and Vermeule document responses to recent emergencies terrorist attacks and financial crises — and the broad delegation of everyday, non-emergency discretionary powers to expert administrative agencies. This evidence leads them to conclude that the executive is the "center of institutional gravity." 118 Adopting Schmitt's institutional insights, they argue that the need for fast-paced, coordinated action in response to complex and dynamic policy problems heavily favours the executive. ${ }^{119}$ They argue the legislature and judiciary are ill suited to make decisions under these conditions and cannot effectively constrain executive action. ${ }^{120}$

They offer the federal Administrative Procedures Act, the heart of American administrative law, as an example of the illusory nature of legal constraints. ${ }^{121}$ Posner and Vermeule argue that the Act is shot through with legal black and grey holes. Legal black holes

\footnotetext{
${ }^{116}$ Ibid. at 1884 .

${ }^{117}$ By this they mean legally unbounded. They argue that political constraints, elections, the party system and culture conditions, offer greater constraints than law: Unbound, supra note 10 at 113-4. See, e.g., William E Scheuerman, "Emergencies, Executive Power, and the Uncertain Future of US Presidential Democracy" (2012) 37 Law \& Social Inquiry 743 for criticism of this argument.

118 Unbound, supra note 102 at 11.

119 Ibid. at 31-2.

${ }^{120}$ Ibid. 25-6 and 52-3. Further, according to Posner and Vermeule to the extent that the legislature and judiciary attempt impose these constraints, as liberal legalists would have them do, they are likely to get it wrong and undermine sound decision-making, defined by Posner and Vermeule as the results of cost-benefit analysis.

${ }^{121} \mathrm{Ibid}$. at 93-6.
} 
are the kinds of agency action that are exempted from judicial review. ${ }^{122}$ Legal grey holes are those standards that judges can relax, when under pressure from the executive, so that executive action is not meaningfully constrained. ${ }^{123}$ Posner and Vermeule therefore conclude that rule-of-law constraints are "shaky in normal times and weak or non-existent in times of crisis." ${ }^{124}$ The problem of the emergency, in other words, is the problem of discretion writ large.

Canadian administrative law has been strongly influenced by the work of AV Dicey, ${ }^{125}$ who was also a committed liberal constitutionalist and thus vulnerable to Schmitt's critiques. Dicey maintained that “ '[m] artial law'...is unknown to the law of England....This is unmistakable proof of the permanent supremacy of the law under our constitution." ${ }^{126}$ Dicey thus rejected the dualist fiction; his conception of the rule of law made no provision for a separate emergency powers regime. ${ }^{127}$ Dicey's conception of the rule of law was "dualist," but in different sense. He distinguished between the dual roles of the legislature and the judiciary. On his view, the legislature possessed a monopoly over law making whereas the judiciary possessed a monopoly over legal interpretation. ${ }^{128}$ For Dicey, Parliamentary supremacy and the rule of law were the twin pillars of the English constitution. While Parliament had a monopoly over law-making, this power was always subject to the supervision of the courts. He could

\footnotetext{
${ }^{122}$ For example, only "agency action" is reviewable by the courts, which the US Supreme Court has held does not include "programmatic decisions." Thus, the failure of an agency to address the use of off-road vehicles in a wilderness area not an action reviewable by the court: Norton v Southern Utah Wilderness Alliance, 542 US 55 (2004).

${ }^{123}$ For example, the "arbitrary and capricious" standard for reviewing agency policy choices and factual findings: Unbound, supra note 10 at 93-6. See: Evan J Criddle, "Mending Holes in the Rule of (Administrative) Law" (2010) 104 Northwestern University Law Review 1271 for a powerful critique, that is consistent with the argument presented in Chapter 5 of this thesis.

124. Unbound, supra note 10 at 4.

125 "Rethinking" and Loughlin, supra note 55.

${ }_{126}$ A V Dicey, Introduction to the Study of the Law of the Constitution, 10th ed (Toronto: Macmillan Company of Canada, Ltd, 1959) at 287-8 [Dicey].

${ }_{127}$ Compare “Typology”, supra note 72 with Dyzenhaus' interpretation, which we consider in Chapter 5.

128 "Rethinking", supra note 55 at 198
} 
therefore maintain the liberal constitutional commitment to the subjection of all political power to the rule of law.

But Dicey was also infamously hostile to the administrative state and therefore saw no distinct role for the executive. ${ }^{129}$ The expanding administrative state threatened his vision of the constitution. Discretionary administrative decision-making, which requires weighing competing policy considerations, threatened the legislature's monopoly over law-making. And when an administrative decision-maker must interpret its authorizing legislation, it threatens the judicial monopoly on interpretation. Unlike either legislative or judicial powers, Dicey understood administrative decisions as inherently arbitrary. Legislation - even by a supreme Parliament -is limited by its general and prospective nature and the supervision of the courts. ${ }^{130}$ While the courts decide individual cases, they are constrained by the doctrine of precedent and the obligation to issue public reasons for their decisions. Dicey sought to protect the individual from the exercise of arbitrary state power by repudiating its primary source: the administrative state.

Dicey's insistence on dual constitutional monopolies and his denial of distinct executive power gives rise to a de facto doctrine of a strong separation of powers, even in a Parliamentary system which otherwise lacks such a strong separation. In other words, Dicey can be interpreted as the source of a formal conception of the rule of law. ${ }^{131}$ We will see how this plays

\footnotetext{
129 Dicey, supra note 126 at 188.

130 TRS Allan, Constitutional Justice: A Liberal Theory of the Rule of Law (Oxford: Claredon Press, 2001) at 14-6 (noting the connection here between Dicey and Hayek and their mutual disliking of the administrative state, not only for political reasons but because of its inherent potential for arbitrariness).

${ }^{131}$ Dyzenhaus Constitution, supra note 13 at 71 (noting Dicey's rigid view of the separation of powers). His is also thought of as a formal account because Dicey distinguished between the formal qualities that law must have to be law and the substantive ends the law purports to achieve: Paul Craig, "Formal and Substantive Conceptions of the
} 
out in Canadian administrative law in Chapter 3. But for now it is sufficient to note that this is the same conception of the rule of law that fails Schmitt's challenge. It denies the need for exceptional discretionary powers to respond to the emergency and it denies the need for ordinary discretionary powers in the form of the everyday administrative state. To the extent that the formal conception of the rule of law governs Canadian administrative law, we can expect that, as Posner and Vermeule observe, it too will be riddled with legal black and grey holes.

\section{Conclusion}

This chapter has set out the framework for the thesis. I have argued that the best way to understand the problem that environmental issues pose for law is as an ongoing emergency. Environmental issues, like emergencies, contain two epistemic features: the inability to predict which issues have catastrophic potential and the inability to know in advance how to respond should a catastrophe occur. These are systemic features of environmental issues that arise from the fact that ecological systems are complex and adaptive. It is therefore not possible to predict the effects of our decisions on the environment. Indeed, it is not even possible to reliably eliminate the possibility of a catastrophe. As the mountain pine beetle epidemic illustrated, even seemingly well-understood environmental issues can have catastrophic potential. This justifies approaching all of environmental law from the emergency perspective.

We also saw that the problem of emergencies can be framed in terms of Schmitt's challenge. This is the fundamental challenge to show how emergencies can be governed by law. We saw that Schmitt assumes a formal conception of the rule of law, in which the legislature is

Rule of Law" (1997) 3 Public L 467 at 470-2. However, Chapters 5 and 6 will contest this interpretation of Dicey in a way that also blurs this line between formal (or procedural) and substantive accounts of the rule of law. 
the sole source of legitimate legal norms. For those who adhere to this conception of the rule of law, there are only two possible responses to the emergency: resort to the exercise of extralegal powers, or attempt to accommodate the emergency within legal order. Both responses create a dual legal order. They assume that we can readily distinguish emergencies and subject them to exceptional legal treatment. However, we saw that this dualism is a fiction. Once we concede that emergencies require exceptional powers, we no longer have a legal basis on which to confine the use of emergency powers. In addition, accommodating emergency powers within legal order risks creating legal black and grey holes within ordinary legislation. In other words, the attempt to subject emergency powers to legal constraints only buries the discretionary nature of these powers under a façade of legality.

Finally, we saw that Schmitt's challenge is not limited to the exceptional emergency; rather it is a broader attack on the liberal constitutional state. For Schmitt and his followers, the emergency simply brings to the surface the inadequacy of liberal constitutionalism for responding to a fast-paced world. Since legislatures cannot anticipate unforeseeable events or quickly respond to urgent or rapidly evolving problems, the best they can do is delegate broad powers to the executive. From the perspective of the formal conception of the rule of law, emergencies and discretionary administrative powers exist in legal black or grey holes. That is, they are governed only by law in the thinnest possible sense; the executive is not subject to meaningful rule-of-law constraints.

We will see in Chapter 5 that we need not accept the terms of Schmitt's challenge. We can reject both the formal conception and its dualist assumption. But first, we are now in a position to uncover the existing assumptions in Canadian environmental law about both the 
nature of environmental issues and the nature of the rule of law. We can now subject existing approaches to environmental law to Schmitt's challenge. 


\section{Environmental Reform: The Problem of Discretion
in Environmental Law}

\section{Introduction}

The concept of the environmental emergency reveals that the epistemic features of emergencies are inherent in environmental issues. The complex, adaptive nature of ecological systems means that our understanding of environmental issues and their potential regulatory solutions is necessarily limited. We cannot reliably distinguish in advance between sound policy choices and catastrophic choices and this undermines our ability to govern environmental issues through ex ante legal rules. The environmental emergency, like all emergencies, reveals the necessity of executive discretion. This conclusion poses a key problem. Just as discretionary emergency response decisions can and often do undermine civil liberties, discretionary environmental decisions can and often do undermine environmental protection.

The relationship between environmental degradation and administrative discretion is understandably the concern of many prominent Canadian environmental law scholars. They argue that discretion is a fundamental and pervasive problem in Canadian environmental law and must be remedied. I call this "the environmental reform position." I argue that the environmental reform position has identified a symptom in environmental law (discretion) without diagnosing its underlying theoretical cause. We will see that environmental reformers are rightly concerned with discretion because Canadian environmental law is, by and large, governed by a formal conception of the rule of law. Discretionary environmental decisions are therefore not subject to meaningful rule-of-law constraints. However, environmental reformers have missed the deeper theoretical challenge. Thus the solutions that they propose are also premised on the formal conception and, therefore, provide no solution at all. 
The environmental reform position is a stylized account that covers a range of reformoriented scholarship and policy proposals in Canadian environmental law. Individual reformers differ in their reasons for adopting the reform positions and their proposals differ in the details. By grouping this literature and approaching it collectively from the perspective of the environmental emergency, we are able to tease out its assumptions about law, democracy and the nature of environmental problems. We will see that the persistence of the formal conception offers an explanation for a wide range of judicial decisions reviewing the exercise of discretionary authority over the environment. However, in failing to recognize the limits of the formal conception, environmental reformers have been complicit in the failed attempt to “accommodate” the environmental emergency within legal order.

In the first part of the chapter I introduce the environmental reform position. The common thread amongst environmental reformers is that administrative discretion is both a defining feature and fundamental flaw in Canada environmental law. ${ }^{1}$ In the second part I argue that the emergency perspective validates the environmental reform position's concern that discretion can be exercised in an arbitrary fashion without any real chance of legal recourse. This is because the formal conception of the rule of law persists in the environmental context and it leads judges to create legal black and grey holes. We will see that discretionary environmental decisions - such as decisions to issue regulations or licenses - exist in a legal black hole. The formal conception leads judges to find these administrative decisions not

\footnotetext{
${ }^{1}$ David Boyd, Unnatural Law: Rethinking Canadian Environmental Law and Policy (Vancouver: UBC Press, 2003) at 154, 231 [Boyd], D Paul Emond, "“Are We There Yet?” Reflections on the Success of the Environmental Law Movement in Ontario" (2008) 46 Osgoode Hall LJ 219 at 224 [Emond], Lynda Collins, "Tort, Democracy and Environmental Governance: The Case of Non-Enforcement" (2007) 15 Tort L Rev 107 at 111 [Collins]. For an American version of the environmental reform position see the aptly entitled: Mary Christina Wood, "'You Can't Negotiate with a Beetle:" Environmental Law for a New Ecological Age" (2010) 50 Natural Resources J 167.
} 
justiciable, or subject only to review for their vires, and exempt from the common law requirement of procedural fairness. Even where the legislature has attempted to impose some, albeit minimal, substantive constraints on the exercise of discretion, judges are reluctant to give these constraints any teeth. Formalist judges, in other words, create legal grey holes. In the third part I turn to the solutions offered by the environmental reform position. I argue that both proposed solutions - stricter legislated rules and independent decision-makers - are products of the formal conception of the rule of law. In other words, just like proponents of the accommodation approach in the emergency context, environmental reformers have failed Schmitt's challenge.

\section{Part I. The Environmental Reform Position}

Since environmental issues are best understood as an ongoing emergency, they present the unavoidable problem of administrative discretion. However, in reaching this conclusion, the environmental emergency conflicts with a dominant position in Canadian environmental law: the environmental reform position. While the environmental reform position is not monolithic, its core attributes are shared amongst many Canadian environmental law scholars. At base, environmental reformers object to the extent of administrative discretion that permeates Canadian environmental law. David Boyd calls environmental statutes "paper tigers"2 because their lofty goals are subtly but consistently undermined by discretionary "loopholes" through which industry receives authorizations to pollute, degrade and harm the environment. ${ }^{3}$ To take but one example, Canada's National Parks Act states that national parks must be managed in a

\footnotetext{
${ }^{2}$ Boyd, supra note 1 at 231.

${ }^{3}$ For some examples of the environmental reform critique of discretion see: Linda Nowlan, "CPR for Canadian Rivers -- Law to Conserve, Protect, and Restore Environmental Flows in Canada" (2012) 23 JELP 237 at 257 , Bruce Pardy \& Annette Stoehr, "The Failed Reform of Ontario's Mining Laws" (2012) 23 JELP 1 at 6, 13-14, Emily Walter, "Decoding Codes of Practice: Approaches to Regulating the Ecological Impacts of Logging in British Columbia" (2005) 15 JELP 143 at 156, and my own previous work: Shaun Fluker \& Jocelyn Stacey, "The Basics of Species at Risk Legislation in Alberta" (2012) 50 Alta L Rev 95.
} 
way that maintains or restores ecological integrity. ${ }^{4}$ But regulations issued under the Act allow a park superintendent to authorize "any person" to "remove, deface, damage or destroy any flora or natural objects in a Park for purposes of Park management." ${ }^{5}$ Exercising this authority potentially undermines the objective of ecological integrity. This legislative structure is commonplace in Canadian environmental law. That is, legislation sets out a general ecological objective or prohibition on pollution, but immediately undercuts the general rule with a wideopen delegation of discretion that allows the administrative decision-maker to authorize contravention of the rule.

The environmental reform position's primary concern is that this unfettered discretion is consistently exercised in a way that undermines environmental protection. Discretion allows decision-makers to favour short-term interests rather than long-term environmental protection. ${ }^{6}$ This observation is supported by numerous theories of regulation which posit that regulated industries are able to coordinate and advance their interests within the administrative process, whereas environmental interests are underrepresented due to their diffuse and often intangible nature. ${ }^{7}$ Further, administrative decision-makers often face both epistemic and resource constraints that require considerable cooperation from regulated parties to provide relevant information and to comply with regulation in the absence of rigorous monitoring and

\footnotetext{
${ }^{4}$ Canada National Parks Act, SC 2000, c 32 s8(2).

${ }^{5}$ National Parks General Regulations, SOR/78-213 s12(1). Canadian Parks and Wilderness Society v. Canada (Minister of Canadian Heritage), 2003 FCA 197, [2003] 4 FCR 672 (the federal court deferred to the Minister's approval of the construction of a new highway in Wood Buffalo National Part despite the Minister not even referring in her reasons to the objective of ecological integrity).

${ }^{6}$ Boyd, supra note 1 at 232, 237-8, 263. See also the Commission for Environmental Cooperation, where parties have filed dozens of petitions on Canada's failure to enforce its environmental laws. Online:

$<$ http://www.cec.org/>.

${ }^{7}$ For a nice overview of these theories as well as a critique of their weaknesses and an evaluation of their empirical support, see Stephen P Croley, “Theories of Regulation: Incorporating the Administrative Process” (1998) 98 Colum L Rev 1 at $32 \mathrm{ff}$.
} 
enforcement. ${ }^{8}$ The significance of Canada's natural resource industries in the Canadian economy has nurtured this cozy relationship between industry and government, ${ }^{9}$ which, in turn, fuels a deep distrust of executive discretion by environmental reformers.

Bruce Pardy has considered at length this relationship between environmental protection, discretion and the rule of law. He writes:

"Environmental law is one of the most extreme examples of legal disciplines in which the commitment to principles of predictability, abstraction, and separation of powers has been consistently abandoned. Without a system of generally applicable environmental rules, environmental governance becomes largely a matter of discretionary judgment calls. Discretionary decision-making means that any particular decision can be justified by social, economic, political, cultural, or aesthetic concerns of the moment, even if they have deleterious long-term effects on ecosystem function. Environmental decisions thus become political positions." 10

From this quote we can tease apart two distinct but related concerns about discretion in environmental law.

Pardy's first concern, consistent with the sentiments outlined above, is with the correlation between discretion and environmental degradation. ${ }^{11} \mathrm{He}$ worries that the concentration of power over environmental decisions allows special interests to undermine the

\footnotetext{
${ }^{8}$ D Paul Emond, “The Greening of Environmental Law” (1990) 36 McGill LJ 742 at 744-5.

${ }_{9}^{9}$ Stepan Wood, Georgia Tanner \& Benjamin Richardson, "What Ever Happened to Canadian Environmental Law?” (2011) 37 Ecology LQ 981 at 1025 ["What Ever Happened”].

${ }^{10}$ Bruce Pardy, "Environmental Assessment and Three Ways Not to Do Environmental Law" (2010) 21 JELP 139 at 149 (footnotes omitted) [Pardy "EA"].

${ }^{11}$ See also Bruce Pardy, "Abstraction, Precedent, and Articulate Consistency: Making Environmental Decisions" (1998) 34 Cal Western L Rev 427 at 429 [Pardy "Abstraction"].
} 
overall public interest in maintaining ecosystem function. ${ }^{12}$ While Pardy does not frame his work in these terms, we can think of this as a classic republican concern for ensuring that political institutions protect the public good. ${ }^{13}$ In response to this concern, Pardy points to the classic republican solution, that is, dispersing political power through a strong doctrine of the separation of powers. The fact that political power is not dispersed in this way in the environmental context, but rather concentrates in the form of executive discretion, reveals that we risk arbitrary environmental decisions. In other words, environmental decisions are arbitrary when they deviate from the public good and instead serve special interests.

In the same quote we can see that Pardy also articulates a more traditional rule-of-law concern with the requirement of generality. Elsewhere he laments the current state of environmental law, where statutes contain broad and potentially conflicting objectives to "manage" the environment while simultaneously maintaining or promoting natural resource development. ${ }^{14}$ He critiques the lack of generality, equality and predictability in current environmental law and argues that environmental discretion creates the problem of "serfdom." In other words, legal outcomes depend, not on generally applicable rules, but on personal status and who you know. ${ }^{15}$ This use of "serfdom” recalls Hayek's classic liberal account of the

\footnotetext{
12 Pardy "EA", supra note 10 at 153 . He references the risks of political tyranny and potential slippage from legislated goals in his earlier work: Pardy "Abstraction", supra note 12 at 344. Collins eludes to this as well with her concern that environmental legislation that could not, without political cost, be amended or repealed can be covertly undermined through administrative decision-making: Collins, supra note 1 at 111.

${ }^{13}$ I rely on Phillip Pettit, Republicanism: A Theory of Freedom and Government (Oxford: Oxford University Press, 1999) [Pettit] and Henry S Richardson, Democratic Autonomy: Public Reasoning About the Ends of Policy (Oxford: Oxford University Press, 2002) [Richardson] who defend a contemporary version of republican as nondomination. Richardson describes three conceptions of non-arbitrariness (at Chapter 3). Pardy's work would fall under Richardson's "objectivist” conception of non-arbitrariness because he works from the basis that there is an objective limit to the planet's life sustaining capacity. This comes through most clearly in Pardy "EA", supra note 10 at 143-4 where he argues that environmental decisions should not be altered by public input.

${ }^{14}$ Pardy, "EA", supra note 10 at 142-3.

${ }^{15}$ Pardy, "Abstraction”, supra note 11 at 429-430.
} 
rule of law, which has a clear influence on Pardy's work. ${ }^{16}$ Drawing on Hayek, Pardy argues general, equal and certain legal rules recognize the "right of the citizen to adapt to environmental limits set by government." ${ }^{17}$ Discretionary environmental decisions interfere with an individual's ability to live her own life. ${ }^{18}$

Pardy is an environmental libertarian. He therefore objects to government "planning functions" that extensively interfere with the private sphere. ${ }^{19}$ But both he and environmental reformers of different political persuasions would recognize a basic individual right to a healthy environment. ${ }^{20}$ Such a right stems from the fact that "all humans depend on healthy ecosystems for life, health and well-being." ${ }^{21}$ Discretionary environmental decisions thus risk arbitrariness because they pose a threat to a fundamental right to a healthy environment.

The environmental reform position reveals that existing environmental law is potentially arbitrary in two related senses. First, it allows special interests to co-opt the decision-making process and undermine the public good. Secondly, discretion means that environmental decisions are not taken through general and predictable legal rules. It is thus arbitrary in that it does not protect individual autonomy - the basic ability to live one's life free from "ecological interference" 22 from the government and others. The environmental reform position reveals that, even though discretionary environmental decisions are authorized by a

\footnotetext{
${ }^{16}$ Bruce Pardy, "The Pardy-Ruhl Dialogue on Ecosystem Management Part V: Discretion, Complex-Adaptive Problem Solving and the Rule of Law" (2008) 25 Pace Envtl L Rev 341 at 341 [Pardy "Part V"].

${ }_{17} \mathrm{Ibid}$. at 351 and Bruce Pardy, "Environmental Law and the Paradox of Ecological Citizenship: The Case for Environmental Libertarianism" (2005) 33 Environments 25 at 30 and 34 [Pardy "Citizenship"].

${ }_{18} \mathrm{Ibid}$.

${ }^{19}$ Pardy, "Abstraction", supra note 11 at 429-430.

${ }^{20}$ David Boyd, The Right To A Healthy Environment: Revitalizing Canada's Constitution (Vancouver: UBC Press, 2012) [Boyd "Right"], Lynda Collins, "An Ecologically Literate Reading of the Canadian Charter of Rights and Freedoms" (2009) 26 Windsor Rev Legal \& Soc 7 (on the connection between a healthy environment and existing rights and freedoms).

${ }^{21}$ Boyd "Right", supra note 20 at 2.

Pardy "Citizenship", supra note 17 at 34 .
} 
democratic legislature and formally subject to judicial review, they nonetheless pose a significant threat of arbitrariness. Current environmental law, in short, is both democratically and legally suspect. ${ }^{23}$

The response to the mountain pine beetle epidemic, however, illustrates that administrative discretion is inevitable in environmental law. The British Columbia government's emergency response was to dramatically increase the amount of timber harvested in the province to try to contain the epidemic and to harvest timber before it lost its commercial value. ${ }^{24}$ This response was implemented through three mechanisms, all of which were exercises of administrative discretion. First, the Lieutenant Governor in Council (LGIC) promulgated an emergency Bark Beetle Regulation, ${ }^{25}$ which allowed harvesting coordination and relaxed certain administrative requirements. The Bark Beetle Regulation delegated further, unfettered discretionary authority permitting the Minister to identify emergency management areas for mountain pine beetle treatment "if satisfied" that a forest was attacked or under danger of attack. ${ }^{26}$ Second, the Minister of Forests significantly lowered the amount of government royalties on beetle-killed timber in order to encourage forestry companies to prioritize its harvest. Under the Forests Act, the Minister is delegated discretion to determine the "policies and practices" 27 for setting these royalties. Third, the province's Chief Forester

\footnotetext{
${ }^{23}$ Richardson, supra note 13 labels this problem "bureaucratic domination," in which we are subject to the arbitrary will of administrative decision-makers. He continues: "Power is arbitrary when it is not adequately controlled by a fair process of decision in which those subject to it are treated as free and equal and their fundamental rights and liberties are protected." (at 250-1).

${ }^{24} 95 \%$ of British Columbia's forests are owned by the Crown. Forest companies gain harvesting rights by entering into tenure agreements with the government. These tenure agreements are the subject of provincial legislation and regulations that govern specific forestry practices. For a general overview, see: Timber Tenures in British Columbia (Victoria: Government of British Columbia, 2012), online: Ministry of Forests $<$ https://www.for.gov.bc.ca/ftp/hth/external/!publish/web/timber-tenures/timber-tenures-2006.pdf>.

${ }^{25}$ Bark Beetle Regulation BC Reg 286/2001 [Beetle Regulation].

${ }^{26} \mathrm{Ibid}$. at 2.

${ }^{27}$ Forest Act, RSBC 1996, c 157 s. 103 [Forest Act].
} 
exercised his discretion to dramatically increase the allowable harvest in the province, well above already unsustainable levels, in order to outpace the beetles. ${ }^{28}$

These three emergency response decisions were all products of the exercise of everyday administrative discretion: regulation-making, individual exemptions from ordinary forestry requirements, and discretionary decisions on royalties and total harvest. These are all forms of discretion that the environmental reform position views as objectionable. Yet it is difficult to see how it could be otherwise. Even critics of the province's emergency response conceded the necessity of such discretion. ${ }^{29}$ All of the decisions require sophisticated knowledge of the forest industry, and moreover, require continual updating across all regions of the province in response to changing environmental, economic and social conditions. Administrative discretion is necessary not only to respond immediately to an urgent environmental catastrophe — to stem the tide of a mountain pine beetle epidemic, for example - but also to ensure that each environmental decision reflects the best understanding of the invariably dynamic problem at hand.

We know from Chapter 2 that attempts to "accommodate" the environmental emergency within legal order will fail to impose meaningful legal constraints on the exercise of discretion. Yet we shall now see that the formal conception nonetheless persists in Canadian environmental law. It results in the creation of legal black and grey holes. In short, environmental reformers are right to be concerned about arbitrariness in environmental decision-making.

${ }^{28}$ Harry Nelson, "Does a Crisis Matter? Forest Policy Responses to the Mountain Pine Beetle Epidemic in British Columbia" (2007) 55 Can J of Ag Econ 459 at 465. We examine the Chief Forester's role in detail in Part III.B.

${ }^{29}$ Even alternative proposals would have proceeded through the same discretionary regulatory mechanisms. See generally Ben Parfitt, Battling the Beetle: Taking Action to Restore British Columbia's Interior Forests (Canadian Centre for Policy Alternatives, 2005). 


\section{Part II. Black \& Grey Holes in Canadian Environmental Law}

In Chapter 2, I introduced Dicey and attributed the formal conception of the rule of law in Parliamentary systems to one interpretation of his work on the English constitution. ${ }^{30}$ We saw that Dicey's formal conception did not contemplate any real role for the administrative state. Despite this, his influence on Canadian administrative law continues to this day. ${ }^{31}$ In this Part, we will first see how the formal conception of the rule of law has led Diceyan judges to broker a practical, if unstable, compromise with the reality of the administrative state. We will then see that this practical and unstable compromise is the source of legal black and grey holes in environmental law. Where the legislature delegates unfettered discretion to administrative decision-makers to regulate the environment, formalist judges will be content to create legal black holes. Where the legislature has attempted to impose some substantive constraints on environmental decision-makers, formalist judges will create legal grey holes. In other words, they treat these constraints as purely formal requirements that do not effectively constrain the exercise of discretion.

In Chapter 2, we saw how the formal conception of the rule of law emerges from Dicey's notion that the judiciary and the legislature have competing monopolies. Despite Canada's robust administrative state, this formal understanding of Dicey's rule of law has been "remarkably influential" 32 in the development of Canadian administrative law. Its longstanding influence is responsible for the complex and convoluted development of administrative law doctrine as courts struggle to reconcile their acceptance of the legitimacy of the administrative

\footnotetext{
${ }^{30}$ Recall also that I noted there is an alternative interpretation of Dicey that leads to a substantive conception of the rule of law. We examine this alternative interpretation in Chapter 5.

${ }^{31}$ The observation that the formal conception of the rule of law persists in the environmental context is a striking conclusion because in many significant ways Canadian courts have moved away from a formal conception of the rule of law. This evolution in Canadian administrative law is key to the argument of Chapter 5.

${ }^{32}$ National Corn Growers Assn v Canada (Import Tribunal), [1990] 2 SCR 1324 at para 74, 74 DLR (4th) 449, Wilson $\mathrm{J}$.
} 
state with an account of the rule of law that is inherently hostile to it. Where the legislature deliberately delegates discretionary authority to administrative decision-makers, Diceyan—or formalist - judges attempt to preserve the formal conception of the rule of law in the face of conflicting legislative intentions. On the one hand, the legislature signals that it is the administrative decision-maker, not the court, that has final decision-making authority; but, on the other, it signals that there are limits to the decision-makers power through the boundaries set out in the statute. The formalist judge attempts to reconcile this tension by according the administrative decision-maker "free rein within certain legal limits." 33

"Free rein within limits" reflects a practical compromise where judges will strictly patrol the boundaries of the legislation ${ }^{34}$ - or the decision-maker's jurisdiction-as well as decide other matters that fall squarely within the judiciary's traditional monopoly, such as constitutional issues, or the common law. ${ }^{35}$ But they give decision-makers free rein over the substance of their decisions. In other words, formalist judges are content to create legal black holes. Issues that fall within the administrator's statutory jurisdiction are only governed by the rule of law insofar as they are authorized by validly enacted legislation.

The problem is that the formal conception reflects a pragmatic stance that judges should refrain from interfering with decisions that would traditionally fall under the legislature's lawmaking monopoly. Issues that look like lawmaking, in the sense that they involve the exercise of discretion over complex policy considerations, are off limits. ${ }^{36}$ But we

\footnotetext{
${ }^{33}$ David Dyzenhaus \& Evan Fox-Decent, "Rethinking the Process/Substance Distinction: Baker v Canada” (2001) 51 UTLJ 193 at 204 ["Rethinking"].

${ }^{34}$ Paul Craig, Public Law and Democracy in the United Kingdom and the United States of America (Oxford: Claredon Press, 1990) at 22.

35 "Rethinking", supra note 33 at 204.

36 Ibid. at 207.
} 
shall see that this pragmatic stance lacks a principled basis on which formalist judges can justify the creation of these legal black holes. ${ }^{37}$ It also means that, where the legislature attempts to impose some minimal constraints on the exercise of discretion, formalist judges are uncomfortable giving these constraints any real meaning. In other words, formalist judges are also content to create legal grey holes, which allow the executive to claim it acts in accordance with the rule of law, but without being subject to any effective constraints.

\section{A. Legal Black Holes: Environmental Regulations}

The environmental reform position argues that discretion in Canadian environmental law evades rule-of-law constraints. Reformers observe that courts find environmental decisions unreviewable or will accord decisions such "extreme" deference that they are not meaningfully constrained. ${ }^{38}$ The environmental emergency validates this observation by explaining that general, policy-laden environmental decisions attract a formal conception of the rule of law, which leads to the creation of legal black holes. Since these decisions look like lawmaking - and sometimes are a form of lawmaking - formalist judges do not understand these decisions to be internally governed by the rule of law. As we saw in the mountain pine beetle context, the legislature delegates significant discretionary authority to the executive to issue regulations. This means that the executive has discretion both over whether to issue regulations, and the substance of those regulations. The environmental emergency reveals that regulations issued by the executive exist in a legal black hole. From the perspective of the formal conception, the failure to issue regulations is not justiciable and regulations themselves are subject only to vires review and are not subject to the requirements of procedural fairness.

\footnotetext{
${ }^{37} \mathrm{Ibid}$. at 202.

${ }^{38}$ Boyd, supra note 1 at 269.
} 
On the failure to issue regulations, the law is very clear. The matter is not justiciable, that is, not subject to judicial review. ${ }^{39}$ Regulations have the force of law; they are a form of delegated legislation and thus an extension of Parliamentary sovereignty. Parliament can choose to legislate (or not) over any matter. Courts have applied the same logic to delegated legislation to conclude that they cannot require the executive to issue regulations where no action has been taken. ${ }^{40}$ But regulations cannot, in principle, be entirely off-limits for formalist judges. Regulations, just like any other delegated authority, are bound by their statutory scheme and the formalist judge must patrol those statutory boundaries. Formalist judges, then, feel a great deal of strain when faced with challenges to the legality of regulations.

The Federal Court's decision in Friends of the Earth ${ }^{41}$ brings this formalist tension to the surface. The issue arose from the executive's intransigence regarding the Kyoto Protocol Implementation Act. The legislation, passed by the opposition parties against the minority government, set out ostensibly binding requirements, including a requirement to issue regulations to mitigate climate change by a specific deadline, which the executive failed to do. ${ }^{42}$ The administrative decision not to issue regulations by a statutory deadline fell squarely within the traditional lawmaking monopoly, which requires judicial abstinence from the formalist perspective. But the refusal to act also directly undermined the objective of the legislation and the specific language of the authorizing provisions. The only way the Federal Court could make sense of this tension was to conclude that the provisions "reflect only a permissive intent," 43

\footnotetext{
${ }^{39}$ For example, Canadian Council for Refugees v Canada 2008 FCA 229, [2009] 3 FCR 136 at para 53; John M Keyes, Executive Legislation 2d ed, (Toronto: LexisNexis Canada, 2010) at 529.

40 Ibid.

${ }^{41} 2008 \mathrm{FC} 1183$, [2009] 3 FCR 201 [FOTE].

${ }^{42}$ Kyoto Protocol Implementation Act, SC 2007, c 30 ss 7-9.

${ }^{43}$ FOTE, supra note 41 at para 37.
} 
that in other words the legislature did not intend to create legally enforceable duties. ${ }^{44}$ This interpretation allowed the Federal Court to keep the formal conception intact. The Court created a legal black hole by patrolling the boundaries of the legislation and simply concluded that there were none that could be legally enforced. ${ }^{45}$

In addition, the executive often has broad discretion over the substance of the regulations. As we saw in the mountain pine beetle example, the Forest Practices Code delegated the authority to make regulations for "the protection of forest resources," which authorized the emergency regulation. The environmental reform position highlights the concern that the substance of the regulations can easily undermine the environmental protection goals articulated by the legislature. Since, once validly enacted, a regulation has the force of law, ${ }^{46}$ the environmental reform position is particularly concerned that the executive has effectively unconstrained discretion over the substance of regulations.

Judicial review of regulations in Canada again seems to validate this concern. Regulations are subject to judicial review only for their vires; that is, on the narrow question of whether they fall within the scope of their statutory authority. ${ }^{47}$ Vires review is a direct product of the formal conception, where the judicial role is to police the boundaries, to interpret the enabling statute to ensure that the regulation falls within its jurisdiction. The substance of the

\footnotetext{
44 Ibid. para 35.

${ }^{45}$ Ibid. para 46 ("the Court has no role to play reviewing the reasonableness of the government's response to Canada's Kyoto commitments within the four corners of the [Act]”).

46 Statutory Instruments Act, RSC 1985, c S-22 [Statutory Instruments Act].

${ }_{47}$ The Supreme Court most recently affirmed this in Katz Group Canada Inc v Ontario (Health and Long-Term Care), 2013 SCC 64, [2013] 3 SCR 810. The Katz decision has effectively created an exception to the normal standard of review analysis that a court would conduct to determine if it should review an administrative decision for reasonableness or correctness. For an overview of recent developments with the standard of review analysis, see: Paul, Daly, "The Scope and Meaning of Reasonableness Review" (2015) 52 Alta L Rev forthcoming. We take up the Supreme Court of Canada's approach to reasonableness review in Chapter 5.
} 
regulations - their wisdom, or their ability to achieve the legislative objective- are entirely offlimits to the courts. Only if the regulation is "irrelevant," "extraneous," or "completely unrelated to the statutory purpose" will the court find that the regulation is invalid. ${ }^{48}$ Regulations, in other words, fall within a legal black hole where they are subject only to the minimal legal constraint that they are validly enacted.

The persistence of the formal conception means that it is extremely difficult to challenge regulations that undermine environmental protection goals contained in their enabling legislation. Both the purpose of environmental legislation and the specific provisions enabling regulation-making are often cast in broad terms meaning that it would take an outrageous regulation to exceed these statutory limits. In Sandy Pond, ${ }^{49}$ the Federal Court upheld a regulation that permitted the conversion of a lake into a toxic tailings pond for untreated mining effluent. The Federal Court reasoned that the Fisheries Act was for the "general management" of the fisheries. ${ }^{50}$ The court concluded that "Parliament legislated the provisions allowing the enactment of the Regulations in question here.... The will of the people, with respect to legislation, can be expressed at the ballot box." ${ }^{51}$ In other words, so long as the regulation fell within the broad boundaries of the legislation, the substance of the regulations is a lawmaking function that falls properly within the legislature's monopoly, not the court's.

Moreover, environmental regulations are not subject to the common law requirement of procedural fairness. The doctrine of procedural fairness has consistently required judges to

\footnotetext{
${ }^{48} \mathrm{Ibid}$. at para 28.

49 Sandy Pond Alliance to Protect Canadian Waters Inc v Canada, 2013 FC 1112 at para 88 [Sandy Pond].

${ }^{50}$ Ibid. para 70 (relying on the Supreme Court of Canada's description of the Act in Ward v Canada (Attorney General), [2002] 1 SCR 569).

${ }^{51}$ Sandy Pond, supra note 164 at para 88.
} 
formally classify decisions to determine whether the duty of fairness applies. ${ }^{52}$ While the courts have expanded the duty of fairness from decisions categorized as judicial or quasi-judicial to most administrative decisions, they have retained a category of "legislative" decisions which are exempt from common law requirements. ${ }^{53}$ The legislative category is a remnant of the formal conception, under which the integrity of the legislative process was maintained through judicial non-interference. ${ }^{54}$ Judges broadened the requirements of procedural fairness to all adjudicatory administrative decisions to preserve the integrity of the judicial process. But they had no such role for decisions of a legislative nature. ${ }^{55}$ Since environmental decisions are often complex, "political" 56 matters which courts implicitly understand as part of the traditional lawmaking monopoly, they are frequently labeled "legislative" in nature.

The formal conception has thus resulted in a long history of judicial abstinence from supervising regulation and other policy-laden administrative functions. The problem is that the formal conception is a product of a practical compromise, rather than a principled one. It singles out the "lawmaking" character or appearance of the administrative decision. Regulations fall squarely within the "lawmaking" category because they are functionally identical to legislation and are thus understood to be outside the proper sphere of the courts. But this overstates important distinctions between the two. Unlike the legislature, the executive has no inherent authority to make law. This means that regulations always exist within a legal

\footnotetext{
${ }^{52}$ Grant Huscroft, "From Natural Justice to Fairness: Thresholds, Content, and the Role of Judicial Review" C Flood \& L Sossin eds, Administrative Law in Context, 2d (Toronto: Emond Montgomery Publications Ltd, 2012) 147 at $148-9$.

53 Ibid. at $156-7$.

${ }^{54}$ Genevieve Cartier, "Procedural Fairness in Legislative Functions: The End of Judicial Abstinence?" (2003) 53

UTLJ 217 at 237 [Cartier].

55 Ibid. at 237.

${ }^{56}$ Imperial Oil v Quebec, 2003 SCC 58, [2003] 2 SCR 624 at para 38. See also Canadian Society of Immigration Consultants v. Canada (Citizenship and Immigration), $2011 \mathrm{FC} 1435$ at para 113.
} 
framework. Formalist judges ignore the fact that the legislature has deliberately relinquished its monopoly over lawmaking by delegating general policymaking authority to the executive. ${ }^{57}$

Formalist judges frequently justify their reluctance to intervene on democratic grounds. They note that regulations are typically issued by an elected decision-maker, a Minister or Cabinet. But it is incorrect to assume, as the formal conception seems to, that this is a sufficient condition for democratic legitimacy. Legislation is democratic not only because it is enacted by elected officials but also because it is the product of deliberation and open debate by opposing parties. ${ }^{58}$ While formal regulations are subject to some uniform requirements, ${ }^{59}$ such as publication, procedural requirements for regulations are patchy. ${ }^{60}$ Some regulations or delegated authority may be subject to deliberation (for example municipal by-laws), but there are no uniform requirements that ensure regulations have democratic legitimacy. Moreover, the simple fact that a democratic legislature has authorized the exercise of discretion is true of all administrative action and is not sufficient to immunize an administrative decision from judicial oversight in any other context. In short, by treating regulations as a part of the legislative monopoly over lawmaking, the formal conception overstates the similarities between legislation and regulations.

The persistence of the formal conception in the case of regulations presents another problem. Because the formal conception is a product of a practical compromise, there is no principled basis on which to distinguish the kinds of "lawmaking" that attract vires review and

${ }_{57}$ Cartier, supra note 54 at 238.

${ }_{58}$ Ibid. at 242-3.

59 Statutory Instruments Act, supra note 46 (notably, the s.5 requirement of publication).

60 Andrew Green, "Regulations and Rule Making: The Dilemma of Delegation" In C Flood, L Sossin eds, Administrative Law in Context 2d ed (Toronto: Emond Montgomery Publications Ltd, 2013) 125 at 142. Alice Woolley, "Legitimating Public Policy" (2008) 58 UTLJ 153 (arguing that policy decisions that can also easily escape review because of their "lawmaking" character). 
those that are subject to substantive review, or to distinguish those that attract a duty of procedural fairness and "legislative" decisions that do not. While formal regulations may be easy enough to delineate, as we shall now see there are a variety of discretionary environmental decisions that, while not formal regulations, are treated as effectively such by the courts.

For example, the British Columbia courts have found the administrative authority to set royalties - one of the mountain pine beetle responses - is "more legislative than it is administrative" and thus "does not lend itself easily to judicial intervention." ${ }^{61}$ Royalties are determined primarily by way of informal policies approved by the Minister. ${ }^{62}$ The only constraint on the Minister's discretion in determining these policies is that the rate remains above the statutory minimum of $\$ 0.25$. Since the policies are "legislative" in nature, the court will not second guess the adequacy of the factual foundation of the policy, nor identify what factors need to be considered or how much weight to attribute to each factor. ${ }^{63}$ In other words, the policies fall within a legal black hole and are not subject to judicial oversight. ${ }^{64}$

Even in instances where the executive is delegated authority to make an individual decision, judges have relied on the formal conception to give the decision-maker effectively free rein. Under the federal Fisheries Act, for example, the Minister has "absolute discretion" to issue fishing licenses. ${ }^{65}$ The Federal Courts have held that individual licensing decisions are subject to substantive review for reasonableness, but that a decision is only unreasonable if it is "clearly

\footnotetext{
${ }_{61}$ MacMillan Bloedel Ltd v British Columbia (Minister of Forests), [1984] 3 WWR 270, BCJ No 1472 (CA) at para 24 (review of the stumpage policy) [MacMillan].

${ }^{62}$ Forest Act, supra note 27 s $105(1),(1.1),(6),(7)$.

63 MacMillan, supra note 61 at para 27.

${ }^{64}$ For additional, more recent examples see: Arsenault v Canada (Attorney General), 2009 FCA 300, 181 ACWS (3d) 840 and Cassiar Watch $v$ Canada (Minister of Fisheries and Oceans), 2010 FC 152, [2010] FCJ No 282.

${ }^{65}$ Fisheries Act, RSC 1985, c F-14 s 7 [Fisheries Act].
} 
beyond the broad purposes permitted under the Act." 66 This includes situations of bad faith, reliance on an extraneous factor, or failure to comply with a statutorily-imposed procedure ${ }^{67}-$ in other words, the court has simply subsumed vires review under substantive review for reasonableness. Much like the decision in Sandy Pond, it would take an egregious decision for the court to conclude a licensing decision is clearly beyond the purpose of the Act.

In short, there is no clear dimension along which the courts can determine which issues are sufficiently 'political' or 'legislative' in nature that they ought to be exempt from substantive judicial review. ${ }^{68}$ When faced with complex policy matters the court can revert to vires review, even where the decision lacks the insignia of actual lawmaking. Moreover, this pragmatic compromise reached by formalist judges ignores the fact that environmental decision-makers are often delegated the choice of regulatory instrument. ${ }^{69}$ That is, a decision can be taken by way of regulation, informal policy, or ad hoc individual decisions. All options have ostensibly the same effect on the environment and authorized individual, but are subject to potentially different rule-of-law requirements.

\section{B. Legal Grey Holes: Ineffective Substantive Constraints}

We have seen that the formal conception of the rule of law leads judges to create legal black holes by concluding that the substance of discretionary environmental decisions is not subject to judicial review. We shall now see that the formal conception also leads judges to create legal grey holes in cases where the legislature has imposed some minimal substantive

\footnotetext{
${ }^{66}$ Carpenter Fishing Corp. v Canada, [1998] 2 FC 548, 155 D.L.R. (4th) 572 at para 37, reaffirmed in Association des crevettiers acadiens du Golfe inc v Canada (Attorney General), 2011 FC 305.

${ }^{67}$ Ibid.

${ }^{68}$ Cartier, supra note 54 at 233.

${ }^{69}$ For example, the Fisheries Act, supra note 65 s 35(2).
} 
constraints on environmental decisions. These substantive constraints are often set out as a list of factors that the decision-maker must consider. These factors are converted into a legal grey hole when formalist judges construe them as an empty box-ticking exercise that does not effectively constrain the exercise of discretion.

We saw in the mountain pine beetle example that the emergency regulation authorized the Minister to make a designation "if satisfied" that an area was attacked or in danger of being attacked. This language reflects the complex context in which the decision-maker is expected to operate. The decisions taken in response to the mountain pine beetle response were not challenged through judicial review. But similar language has come before the courts in the forestry context. In David Suzuki Foundation v. British Columbia (Attorney General),70 the David Suzuki Foundation challenged the Lieutenant Governor in Council's decision to permit the export of timber from British Columbia's northwest. Under the Forest Act, the LGIC could grant the permit "if satisfied" that, amongst other conditions, the timber was in surplus. ${ }^{71}$ The Foundation argued that the surplus condition was not met and therefore the exemption was ultra vires the Act. ${ }^{72}$ The British Columbia Supreme Court disagreed. It found that the phrase if satisfied that' conferred an "exclusive,"79 "complete, unfettered, subjective discretion" 74 on the LGIC to issue an exemption. The Act only required that the LGIC "be satisfied" that the conditions were met. Since the order itself stated that the LCIG was satisfied as to the existence of the conditions, the Court was not entitled to look beyond the order to assess

\footnotetext{
702004 BCSC 620 [David Suzuki Foundation]

${ }^{71}$ Forest Act, supra note $27 \mathrm{~s} \mathrm{128(1).} \mathrm{At} \mathrm{the} \mathrm{time,} \mathrm{there} \mathrm{was} \mathrm{a} \mathrm{prohibition} \mathrm{on} \mathrm{the} \mathrm{export} \mathrm{of} \mathrm{timber} \mathrm{from} \mathrm{the} \mathrm{region.}$ The permit was an exemption to the prohibition.

72 David Suzuki Foundation, supra note 70 at para 1.

${ }^{73}$ Ibid. at para 11.

${ }^{74} \mathrm{Ibid}$. at para 12 .
} 
whether the objective evidence supported the decision. ${ }^{75}$ The Court was content that there appeared to be "some evidence" and that "the conditions which may have motivated the LGIC...are irrelevant." 76 The Court understood its role in “a basic jurisdictional” sense, meaning that its role was to patrol the boundaries of the legislation and not second-guess decisions taken within those bounds. ${ }^{77}$

Even where the court purports to conduct substantive review to determine whether a decision is reasonable, it can still create a legal grey hole. In Sierra Club v Ontario (Ministry of Natural Resources), 78 the Sierra Club challenged the Minister's decision to permit the disturbance of endangered species habitat for the construction of a new bridge across the Detroit River. The legislation set out the Minister's authority in purely subjective terms, requiring that the Minister consult with "a person who is considered by the Minister to be an expert ....and to be independent of the person who would be authorized by the permit to engage in the activity." 79 At issue was the fact that one expert report on which the Minister relied, and which contradicted a second expert, was produced by an employee of the company bidding for the project. ${ }^{80}$ While the Court expressed reservations about the appearance of independence "which the Minister might have been better to avoid," 81 the Court nonetheless found that the Minister complied with the Act. It did so in purely formal terms. The expert provided the Minister with a statement that declared his independence and the Court therefore

\footnotetext{
75 Ibid. at para 147 ("As in Thorne's Hardware, supra, the LGIC in the case at Bar was obviously satisfied that the Northwest timber was surplus timber and I cannot inquire into the validity of that belief... The decision, including the sufficiency of the evidence, was exclusively for the LGIC.”)

${ }^{76}$ Ibid. para 145 .

77 Ibid. para 91.

782011 ONSC 4655, [2011] OJ No 4373 [Sierra].

${ }^{79}$ Endangered Species Act, 2007, SO 2007, c 6 at 17(2) (The further requires that the Minister form a number of opinions before deciding whether to issue the permit).

${ }^{80}$ Sierra, supra note 78 para 64.

${ }^{81}$ Ibid. para 68.
} 
held that "[s]trictly speaking, it confirm [ed] the independence of the expert." ${ }^{2}$ In the Court's view, all that the Act required was "that the Minister consult and obtain a written report." ${ }^{3}$ In other words, the Court created a legal grey hole. On this view, a legislative requirement to consult with independent experts before deciding whether an activity will jeopardize the survival or recovery of an endangered species is no more than a formal reporting exercise that does not receive meaningful scrutiny on review.

The Court's discomfort with its supervisory role echoed throughout the decision. It held that the subjective language in the legislation served "to broaden the deference the court should provide to the decision to issue the Permit." ${ }^{44}$ It tersely dismissed the Sierra Club's arguments that the purpose of the language was to ensure the Minister consulted the best scientific information available, ${ }^{85}$ and that the Minister's discretion was constrained by the precautionary principle. ${ }^{86}$ The Court stated that to take a more active supervisory role would not accord the "breadth of deference required where a public policy decision is at issue." ${ }^{87}$ Instead, the Court was prepared to allow the Minister the appearance of legality without actually subjecting the Minister's discretion to any meaningful legal constraints.

Indeed it seems that only in egregious cases where the decision completely lacks an evidentiary basis will the court intervene. ${ }^{88}$ So long as there is evidence that the decision-maker turned her mind to the relevant statutory factors - ticked the appropriate boxes - the court

\footnotetext{
82 Ibid. para 65.

83 Ibid. paras 72, 90 .

${ }^{84}$ Ibid. para 39.

${ }^{85}$ Ibid. para 92-3.

${ }^{86} \mathrm{Ibid}$. at para 60 (concluding that it is only one factor to be considered). Chapter 5 addresses the precautionary principle in more detail.

${ }^{87} \mathrm{Ibid}$. at para 63.

88 Alberta Wilderness Association v Minister of Environment, 2009 FC 710, [2009] FCJ No 876; Environmental Defence Canada v Ministry of Fisheries and Oceans, 2009 FC 878, [2009] FCJ No 1052 [Environmental Defence].
} 
will not question the basis for the decision-maker's subjective judgment. ${ }^{89}$ Without some examination of the decision-maker's reasons for a decision, however, virtually any outcome is permissible, since environmental legislation is cast in the broadest of terms. So, for example, a controversial decision to poison wolves in order to protect an endangered caribou population may appear to fall within the range of acceptable outcomes. But, if the reasons disclose that the decision was reached in order to avoid curbing oil and gas development - the real threat to the endangered species - then the decision no longer appears so reasonable. ${ }^{90}$ Indeed, allegations that a decision-maker has been driven by an improper purpose, such as political lobbying ${ }^{91}$ or, as we have seen, a potential stake in the outcome, are often skimmed over on the way to the court's conclusion that the outcome falls easily within the broad perimeters of the legislation. ${ }^{92}$

The formalist judge, in short, focuses on the outcome of the administrative decision and the language of the statute. So long as the decision plausibly fits within the boundaries of the statute, the formalist will find no reason to interfere. To do more-that is, to examine the reasons underlying a decision-would pull judges far away from their traditional monopoly of law-interpretation. ${ }^{93}$ This approach to judicial review validates the environmental reform position's concern that the courts are not proving an effective constraint on potentially

\footnotetext{
89 Sierra, supra note 78 at para 77; See also: Western Canada Wilderness Committee v. British Columbia (Forests, Lands and Natural Resource Operations), 2014 BCSC 808, 84 CELR (3d) 85; David Suzuki Foundation v. British Columbia (Ministry of Environment), 2013 BCSC 874, 240 ACWS (3d) 641; Pacific Booker Minerals Inc. v. British Columbia (Environment), 2013 BCSC 2258, 236 ACWS (3d) 641; Castle-Crown Wilderness Coalition v. Alberta (Director of Regulatory Assurance Division, Alberta Environment), 2005 ABCA 283, 371 AR 370 (all involving qualified discretion). ${ }^{90}$ Doug Inkley, John Kostyack and Sterling Miller, "Tar Sands Development to Lead to Poisoning of Wolves" National Wildlife Federation (2 June, 2012), online: NWF <https://www.nwf.org/News-and-Magazines/MediaCenter/News-by-Topic/Wildlife/2012/02-06-12-Tar-Sands-Development-to-Lead-to-Poisoning-ofWolves.aspx>.

${ }_{91}$ Malcolm v. Canada (Fisheries and Oceans), 2014 FCA 130 at para 57, 76 Admin LR (5th) 179. This point is taken up again in Chapter 5.

${ }^{92}$ Review is often further hampered by court's unwillingness to require decision-makers to give reasons: Lorne Sossin, "The Unfinished Project of Roncarelli v. Duplessis: Justiciability, Discretion, and the Limits of the Rule of Law" (2010) 55 McGill LJ 661 at 684.

${ }_{93}$ Most forceful statement of this Vancouver Island Peace Society v Canada, 19923 FCR 42 at para 12 ("the court is not "an academy of science to arbitrate conflicting scientific predictions.")
} 
arbitrary exercises of discretion. Instead, the adherence to the formal conception of the rule of law has resulted in legal black holes and grey holes with the appearance-not the reality —of legal constraint.

\section{Part III. Impoverished Environmental Reform Solutions}

The argument so far has been that the environmental emergency reveals both the necessity and desirability of discretion, but that the formal conception of the rule of law is incapable of providing meaningful constraints on the exercise of that discretion. In other words, the environmental reform position is right to call our attention to the pervasive problem of discretion in Canadian environmental law, since the courts seem committed to the formal conception which leads judges to create legal black holes and grey holes. In this part, I address the solutions proposed by the environmental reform position. The first solution, crafting less discretionary environmental legislative rules, I will address briefly. We have seen already that this proposal cannot resolve the problem given Schmitt's challenge. The second solution that follows from the environmental reform position is to delegate environmental decision-making to independent experts, such as British Columbia's Chief Forester, the senior forestry official who made the decision to increase the timber harvest in areas affected by the mountain pine beetle epidemic. While independent expert decision-makers play an unquestionably important role in Canadian environmental law, we will see that this does not offer a solution to the environmental reform position's concern. The reform position's turn to independent experts is premised on the assumption that objective expertise can offer the constraints that ex ante legal rules fail to provide. But this approach is dangerous because it risks burying discretion beneath layers of analysis that make it less transparent and more difficult to contest. 


\section{A. Environmental Rules}

The first, and most logical, solution to the environmental reform position's concern over discretion is to minimize or eliminate it through more specific legislative rules. Boyd claims that " $[\mathrm{d}]$ iscretionary language in environmental laws and regulations should be replaced by mandatory language; three decades of experience have proven time and again that politicians and bureaucrats will exercise their discretion to the environment's detriment." 94 Similarly, Pardy advocates crafting an "environmental rule" that would prohibit non-natural, permanent damage to ecosystems. ${ }^{95}$ But for reasons already discussed, neither proposal would solve the problem of discretion. To recapitulate, it is not possible to eliminate discretionary language, because it is often impossible to know in advance what actions should be taken to achieve environmental protection objectives. This is the key insight that follows from viewing the environment as an ongoing emergency.

Pardy's proposal, while considerably more elegant than the current tangle of prohibitions, qualifiers and exemptions found in Canadian environmental law, nonetheless requires the exercise of discretion to interpret and apply its open-textured language. ${ }^{96}$ What constitutes non-natural, or permanent, or even an ecosystem is a highly contextual and often contentious determination. ${ }^{97}$ Under a general environmental rule, discretion would not be eliminated nor minimized, merely shuffled around. The challenge of the environmental emergency cannot be met by simply making fewer or simpler ex ante rules. But to see that this

\footnotetext{
${ }^{94}$ Boyd, supra note 1 at 293.

${ }_{95}^{5}$ Bruce Pardy, "In Search of the Holy Grail of Environmental Law: A Rule to Solve the Problem" (2005) 1 McGill Int'l J Sust Dev L \& Pol'y 29 [Pardy "Holy Grail”].

${ }_{96}$ See also JB Ruhl, "The Pardy-Ruhl Dialogue on Ecosystem Management, Part IV: Narrowing and Sharpening the Questions" (2007) 24 Pace Envtl L Rev 25 [Ruhl $]$ for this observation.

97 The notion that any changes could be identified as "natural" is particularly vulnerable in light of the emerging scientific consensus that we live now live in a new geological epoch, the Anthropocene, characterized by the pervasive and significant impact of human activity on our planet: Paul J Crutzen \& Eugene F Stoermer, "The "Anthropocene" (2000) 41 IGBP Newsletter 17.
} 
solution is inadequate, environmental law has to own up to the emergency features inherent within environmental issues in the first place.

To be clear, however, the emergency perspective does not provide an excuse for failing to enact rigorous environmental laws. Rather, it reflects an appreciation of the fact that our best efforts to protect the environment through legislation will necessarily involve delegating discretion to administrative decision-makers. It is therefore misleading to suggest, as some reformers do, that mandatory legal rules provide an answer. While some first-generation environmental problems lent themselves to outright prohibitions on particularly harmful pollutants or activities, our most pressing environmental issues cannot be legislated away in such a straight-forward fashion. ${ }^{98}$ Instead, we face intractable complexity. Accepting this complexity ought to be liberating, in a sense. It means that policymakers and law reformers can get on with finding solutions rather than prolonging regulatory action as we await a more precise understanding of an ill-posed and dynamic problem. ${ }^{99}$ When legislators are able to articulate clear legal norms we can expect that they will be upheld in court. ${ }^{100}$ But as we have seen, a conception of the rule of law that understands the legislature as the only source of legal norms is insufficient to respond to the environmental emergency.

\footnotetext{
${ }^{98}$ See "What Ever Happened", supra note 9 for some success stories. How we might confront such complexity is the subject of the next three chapters.

${ }^{99}$ Lisa Heinzerling, "Pragmatists and Environmentalists" (2000) 113 Harv L Rev 1421 at 1445.

${ }^{100}$ Good examples are the successful applications for judicial review of executive action under the federal $S p e c i e s A t$ Risk Act: Environmental Defence, supra note 88, Minister of Fisheries and Oceans v David Suzuki Foundation, 2012 FCA 40, Western Canada Wilderness Committee v Canada (Minister of Fisheries and Oceans and Minister of the Environment), 2014 FC 148 (the court highlighted the systemic problem of the Ministries missing the statutory deadlines and granted discretionary relief on the grounds that it was necessary for the court to express its disapproval: para 92). But see Jocelyn Stacey, "The Rule-of-Law Underpinnings of Endangered Species Protection: Minister of Fisheries and Oceans v David Suzuki Foundation, 2012 FCA 40" (2014) 27 JELP 57 (arguing that, while the formal conception of the rule of law led to an environmental victory in this case, it unnecessarily created a legal black hole in the Fisheries Act.)
} 


\section{B. Independent Expert Decision-Makers}

The second solution that follows from the environmental reform position - delegating environmental decision-making authority to independent experts rather than elected members of the executive - raises a similar problem. From the perspective of the environmental reform position, independent experts are appealing because they promise to remove politics from environmental decision-making. For example, the 2012 amendments to the Canadian Environmental Assessment Act transferred final decision-making authority from the National Energy Board to the federal Cabinet. ${ }^{101}$ This prompted an outcry representative of the environmental reform position. The problem, one commentator observed, is that Cabinet lacks the "objectivity and expertise" of the Board: "[s] $[$ hifting the decision for major energy projects from the Board to Cabinet will politicize what was an otherwise independent regulatory process." ${ }^{102}$ As we will see, the Board, just like Cabinet, exercises significant policymaking discretion which cannot be eliminated through objective expertise. Simply put, delegating environmental decision-making authority to an independent expert, without more, does not respond to the environmental reform position's concern about discretion.

British Columbia's Chief Forester is an example of an independent, expert decisionmaker. The Chief Forester implemented one of the province's key responses to the mountain pine beetle epidemic by exercising his discretion to increase the allowable harvest in areas affected by the epidemic. The determination of the annual harvest limit is " $[\mathrm{o}] \mathrm{f}$ all the decisions

\footnotetext{
${ }^{101}$ For an overview of these changes see: Meinhard Doelle, "CEAA 2012: The End of Federal EA As We Know It?" (2013) 24 JELP 1. The National Energy Board's role in conducting environmental assessment is taken up in detail in Chapter 5.

102 Legal Backgrounder: The National Energy Board Act 1985 (Toronto: Ecojustice, 2012) online: $<$ www.ecojustice.ca>. See also Pardy "EA", supra note 10. He doesn't talk about independent expert decisionmakers, but his apparent disdain for public participation suggests that this would be the only institutional apparatus to implement his proposal.
} 
facing forest policymakers, probably the most critical in terms of its economic importance." 103 The Forest Act delegates significant discretion to the Chief Forester to make this determination. It sets out procedural requirements - such as the intervals on which the determination must be made - and substantive factors "to be considered." ${ }^{104}$ As we saw in the previous section, given the dominance of the formal conception of the rule of law, these requirements do not impose significant constraints on how the Chief Forester exercises this discretion.

The assumption underpinning the environmental reform position is that this discretion is less objectionable when in the hands of the independent expert. The promise of independent expert decision-makers lies in the assumption that objective expertise can provide the constraints on discretion that the legislature is unable to provide. ${ }^{105}$ Objective expertise means that the decision-maker is not exercising discretion in any real sense. Rather, an independent decision-maker is simply doing what the legislature, or indeed anyone, would do if they possessed the requisite knowledge. ${ }^{106}$

As we will see, these assumptions are unsound, but they have a strong footing in the history of Canadian environmental law. Indeed, the office of the Chief Forester was originally

${ }^{103}$ Peter Pearse, Timber Rights and Forest Policy In British Columbia - Volume I (Victoria: Government of British Columbia, 1976) [Pearse Commission Volume 1] at 219. Since the vast majority of forested land is Crown land leased out to forestry companies on long-term tenures, the allowable harvest is one of the relatively few junctures at which the government directly influences the timber harvest.

${ }_{104}$ Forest Act, supra note $27 \mathrm{~s} 8$.

${ }^{105}$ For the classic statement of this position see James M Landis, The Administrative Process (New Haven: Yale University Press, 1938) at 25-6. See also: John Willis, "Three Approaches to Administrative Law: The Judicial, the Conceptual, and the Functional" (1935) 1 UTLJ 53 at 75-81 (Willis's functionalist approach emphasizes expediency and the role of expertise, though he does not disavow the necessity of administrative discretion), Ruhl, supra note 96. Elizabeth Fisher's "rational-instrumental” paradigm of administrative constitutionalism was very helpful for working through this argument: Elizabeth Fisher, Risk Regulation and Administrative Constitutionalism (Oxford and Portland OR: Hart Publishing, 2007) [Fisher].

${ }_{106}$ Richard B Stewart, "The Reformation of American Administrative Law" (1975) Harvard Law Review 1667 at 1678; Mark Seidenfeld, "The Role of Politics in a Deliberative Model of the Administrative State" (2013) 1397 at 1404. 
conceived in just these terms. The Chief Forester was to be "a first-class, scientific man, thoroughly well qualified, who has had both technical and practical training and experience."107 The legislature delegated a task that it could not do itself. The Chief Forester was to consolidate and synthesize the vast information on the province's forests in order to act "in all matters affecting the forest interests in the Province." 108 The Chief Forester applied this expertise to determine the rate of harvesting that would maximize long-term timber yield through a technical process known as Hanzlik's formula. ${ }^{109}$ The determination appeared to turn on purely factual questions - the rate of forest growth, the amount of forest mature enough to harvest, areas accessible to loggers for harvesting - and when the Chief Forester applied the results of the analysis, there was no allowance for discretion. ${ }^{110}$ The decision-making authority of the Chief Forester, therefore, appeared consistent with the formal conception of the rule of law because the Chief Forester retained a purely instrumental and technical role in using objective expertise to carry out the democratic mandate of the legislature.

This assumption, that the independent expert applies solely objective expertise, contains two further assumptions. It first assumes that independent decision-makers deal only with factual matters — not political or policy judgments — and second, that these factual matters can be resolved in a way that points to one objective outcome. ${ }^{111}$ As we have seen with the

\footnotetext{
${ }^{107}$ Fred J Fulton, Royal Commission of Inquiry on Timber and Forestry 1909-1910 (Victoria: Government of British Columbia, 1910) at 60, 67.

108 Ibid. at 68.

${ }^{109}$ Larry Pedersen, “Allowable Annual Cuts in British Columbia: The Agony and the Ecstasy” (Jubilee Lecture at the UBC Faculty of Forestry, March 2003) [unpublished], online: British Columbia Ministry of Forestry <http://www.for.gov.bc.ca/hts/pubs/jubilee_ubc.pdf $>$ at 4 [Pedersen]. Hanzlik's formula is Sustained annual yield = mature timber above rotation age/rotation age + mean annual increment for immature timber.

${ }^{110}$ Lois H Dellert, "Sustained Yield: Why Has it Failed to Achieve Sustainability?" Chris Tollefson eds, The Wealth of Forests (Vancouver: UBC Press, 1998) 255 at 257 [Dellert].

${ }^{111}$ Richardson, supra note 13 at 115; Frank Fischer, "Environmental Regulation and Risk-Benefit Analysis: From Technical to Deliberative Policy Making" R Paehlke, D Torgerson eds, Managing Leviathan: Environmental Politics and the Administrative State 2d ed (Peterborough, Ont: Broadview Press, 2005) 59 at 63 [Fischer] (on how science
} 
mountain pine beetle example, the latter assumption that factual issues can be fully resolved so as to produce an objective and positive outcome is flatly refuted by the environmental emergency. Serious environmental issues are replete with remote and unforeseeable possibilities due to the complex and dynamic nature of ecological systems. And, quite to the contrary of what the expertise model posits, there is no objective way to deal with this kind of uncertainty. ${ }^{112}$ Estimating the likelihood of extreme events is fraught with poorly understood relationships and incomplete data, sometimes making it more an exercise of "speculation"113 than objective analysis. Moreover, even seemingly factual issues in determining the harvest rate, such as the rotation age-a "critical variable"114_-in fact turn on a host of assumptions about projected improvements in forest technologies and market conditions. ${ }^{115}$ In short, accurate forestry inventories are necessary but not sufficient to determine the desired rate of timber harvest, since the Chief Forester will have to make discretionary judgments on a whole host of uncertain factors.

The former assumption, that independent experts deal only with factual matters, is also undermined by the Chief Forester's prominent position in directing British Columbian forest policy. In this respect, the Chief Forester's determination of the allowable annual cut is significant for what it does not include. Even now, long after Hanzlik’s formula has faded into

does not answer the questions we need it to in environmental law and this, in turn, opens up more space for environmental politics).

${ }_{112}$ This is the main thesis of Douglas A Kysar, Regulating from Nowhere: Environmental Law and the Search for Objectivity (New Haven, CT: Yale University Press, 2010) [Kysar].

${ }^{113}$ Peter H Pearse, Timber Rights and Forest Policy In British Columbia - Volume 2 (Victoria: Government of British Columbia, 1976) at 232.

${ }^{114} \mathrm{Ibid}$. at $\mathrm{D} 21$. The rotation age sets the age for harvesting a forest stand to maximize forest growth and the pace of harvesting old growth forest: Dellert, supra note 110 at 259.

${ }^{115}$ In the first Royal Commission on the regulation of timber harvest, three experts disagreed on the correct rotation age for coastal Douglas fir, with proposals ranging from 60 to 120 years: Gordon Sloan, The Forest Resources of British Columbia (Victoria: Government of British Columbia, 1956) at 236, 241. Moreover, a recent groundbreaking scientific study has called into question the assumption that aging trees have slower growth rates: NL Stephenson et al, "Rate of tree carbon accumulation increases continuously with tree size" (2014) 507 Nature 90 . 
the background, the allowable annual cut is still dictated by a policy of maximizing sustained yield. Maximum sustainable yield includes the value of timber; it does not account for the myriad other benefits that individuals receive from forests - e.g. hunting, grazing, water quality regulation, biodiversity, and carbon sequestration. Calls to incorporate these nontimber values into the maximum sustained yield model have gone largely unheeded, ${ }^{116}$ evidencing the difficulty of incorporating what are inherently discretionary decisions involving incommensurable trade-offs into a technical model of decision-making premised on an assumption of objective expertise.

In short, the environmental reform position's solution to delegate environmental decisions to independent experts is no solution at all. Independent expert decision-makers exercise considerable discretion that cannot be adequately constrained or guided by objective expertise. This means that expert decision-makers, who are not directly democratically accountable, wield significant policymaking authority that undermines the legislature's monopoly over lawmaking. This purported solution therefore fails to reconcile the exercise of discretion with the formal conception of the rule of law.

Put differently, the attempt to constrain inherently discretionary decisions through nothing more than predetermined expert methodologies creates a façade in the same way that Schmitt predicts that the rule of law operates as a façade over discretionary decisions in times of emergency. Layers of technical analysis that appear to constrain the decision-maker on the substantive outcome in fact require the exercise of significant discretion over what inputs to

\footnotetext{
${ }^{116}$ Dellert, supra note 110 . There has always been unwavering faith that better modelling techniques and more data will respond to criticism. See Pearse, supra note 103 at 233. See also AL (Sandy) Peel, The Future of Our Forests (Victoria, BC: Forest Resources Commission, 1991) 1991 at 75.
} 
include in the technocratic calculation. ${ }^{117}$ Indeed, the Chief Forester's approach to determining the annual harvest was criticized on this very basis, with forestry commentators observing that " $[\mathrm{r}]$ egardless of which formula or model was used, from the 1950 s to the 1990 s, economic forces caused the annual harvest to increase, in spite of the original expectation of reductions in the harvest." 118 Far from constraining administrative discretion, expert forest analyses were in fact capacious frameworks in which decision-makers could covertly succumb to industry pressure. Independent expert decision-makers, therefore, cannot provide a complete answer to the environmental reform position's problem with discretion.

\section{Conclusion}

This chapter has developed several themes introduced in the first chapter. First, we saw that discretion in environmental law poses the risk of arbitrariness. This is the central concern of the environmental reform position, which illustrates that discretionary environmental decisions consistently undermine environmental protection and depart from traditional rule-oflaw values such as generality and consistency. Second, we saw that Canadian environmental law is currently governed by a formal conception of the rule of law. Since the formal conception does not face up to the emergency nature of environmental issues, it results in the creation of legal black and grey holes in environmental law or a façade of legality. The formal conception does not, that is, prevent arbitrary environmental decisions. In addition to this façade of legality, we saw that the formal conception creates a façade of democratic legitimacy. The formal conception treats discretionary environmental decisions as functionally equivalent to legislation. It fails to acknowledge the real democratic deficit that arises when the legislature

\footnotetext{
${ }^{117}$ Kysar, supra note 112 at 72. Maximum sustainable yield is only one example of an expert methodology. Perhaps more common is the methodology of risk-assessment: Fisher, supra note 105 and Fischer, supra note 111.

118 GF Utzig \& DL Macdonald, Citizens' Guide to Allowable Annual Cut Determinations (Vancouver: BC Environmental Network Educational Foundation, 2000) at 6.
} 
delegates environmental decision-making authority to administrative bodies without further requirements to ensure democratic accountability. The reform solution of delegating this discretion to an independent expert risks compounding this democratic deficit.

We also saw that, by neglecting the ways in which the environment confronts us with the unforeseen and potentially catastrophic consequences of an emergency, environmental reformers have come to rely on a formal conception of the rule of law that is incapable of supplying rule-of-law constraints on executive decision-making. The complexity of environmental decisions means that even our best efforts to secure environmental protection through legislation will still contain discretionary authority. The challenge of environmental issues cannot be met through environmental rules. Finally, there is no objective way to resolve the complexity of environmental issues. Scientific uncertainty thus gives rise to normative uncertainty about what actions are appropriate to take. The challenge of environmental issues cannot, therefore, be met by delegating discretion to independent experts. Even the best expertise cannot answer the question of how we ought to proceed in the face of possible, but unknown or uncertain, environmental harm. Much like the accommodation approach to emergency powers, the environmental reform position has failed to answer Schmitt's challenge. 


\section{Environmental Governance: The Problem of Law in
Environmental Law}

\section{Introduction}

For those who adhere to the formal conception of the rule of law there is a second possible response to the emergency. The second response is to concede the necessity of extralegal measures-to concede, in other words, that the rule of law is a luxury that we cannot really afford in times of crisis. In this chapter, we see that the extra-legal approach has a parallel in the environmental context, insofar as some environmental scholars treat the rule of law as simply irrelevant. This parallel is found in the literature on environmental governance, which I introduce in a moment. The argument of this chapter, in brief, is that environmental governance correctly approaches environmental issues from the emergency perspective. However, since defenders of environmental governance assume a formal conception of the rule of law, they "side-line" ${ }^{1}$ consideration of the rule of law in favour of alternative evaluative criteria. I argue that by sidelining the rule of law, environmental governance scholars miss and neglect the internal constitution of the kind of order produced by law. They miss, in other words, the fact that the rule of law creates a particular relationship between lawmaker and legal subject, one that respects the subject's agency and right to be free from arbitrariness. While I expound on the precise nature of this relationship in the final two chapters of the thesis, for present purposes it will be sufficient to observe that environmental governance scholars do not directly confront the potential for arbitrariness. By dismissing the rule of law, they lose sight of its potential for helping articulate the strengths and concerns about particular instances of environmental governance.

\footnotetext{
${ }^{1}$ Leighton McDonald, "The Rule of Law in the "New Regulatory State" (2004) 33 Common L World Rev 197
} [McDonald]. 
Leading Canadian environmental law scholars have identified environmental governance as an emerging approach to environmental law. ${ }^{2}$ Environmental governance covers an expansive body of interdisciplinary scholarship and a diversity of regulatory approaches. It is a subset of a wider new governance literature that addresses questions broadly pertaining to how to regulate. The central feature of new governance is its rejection of the state and its oftassociated top-down regulatory structures as the sole or even primary site of governance. Formal sources of law_-statutes and regulations - are only a small part of this broader picture of governance. As we will see, this leads proponents of environmental governance to reject the formal conception of the rule of law. The formal conception is simply not applicable to the kinds of regulatory innovation that governance scholars promote. According to defenders of environmental governance, general and static legislated norms cannot, on their own, adequately respond to complex environmental problems. Instead, these complex regulatory problems require flexibility, networked public-private relationships, and novel governance institutions.

The problem, however, is that rejecting the 'formalism' of the formal conception does not mean that its underlying concerns disappear. The formal conception, in its ideal form at least, protects against arbitrary state action. In requiring impersonal and general legal rules, it respects the autonomy of the individual to conduct her own affairs. It objects to policymaking by the executive which, as we saw in Chapter 3 , often results in advancing short-term interests

\footnotetext{
${ }^{2}$ Meinhard Doelle and Chris Tollefson eds, Environmental Law Cases and Materials 2d ed, (Toronto: Carswell, 2013) at 285. Tollefson et al define governance as "arrangements for steering and coordinating the affairs of interdependent social actors based on institutionalized rule systems that depart from the traditional strong centralized model of 'government' that was characteristic of many Western liberal democracies in the generation that followed the Second World War..." Chris Tollefson, Fred P Gale, \& David Haley, Setting the Standard: Certification, Governance and the Forest Stewardship Council (Vancouver: UBC Press, 2008) at 218 [Tollefson FSC].
} 
over long-term protection of the environment. To the extent that environmental governance irreparably breaks from the formal conception, it must address this deeper problem of arbitrariness. To anticipate the argument in Chapter 5, I too reject the formal conception of the rule of law, but I offer an alternative that attends to the rule-of-law concerns that much environmental governance scholarship has neglected.

This chapter proceeds in three parts. In the first Part, I introduce the literature on new governance. I argue that we can derive two hypotheses about environmental governance from this literature. The first hypothesis is that instances of environmental governance take seriously the complexity of environmental issues but, in doing so, they reject the formal conception of the rule of law. We will see that this hypothesis emerges from the new governance critique of conventional legal regulation, known as command-and-control regulation. The second hypothesis is that the proliferation of environmental governance is transforming the nature of law itself. This hypothesis is a product of empirical analyses that illustrate how traditional and innovative policy instruments have blended to create novel forms of regulation. Put in terms of the emergency framework, this hypothesis suggests that there is no way to confine governance measures. Like exceptional emergency measures, they appear to be normalizing.

In the second Part, I then test these two hypotheses by examining three examples of environmental governance in the British Columbia forest context: results-based legislation, collaborative ecosystem governance, and transnational forest certification. I argue that each of these examples supports the two hypotheses outlined in Part I. I then examine existing literature on these three forms of governance and show that they only tangentially address the 
underlying rule-of-law concern of arbitrariness. We will see that both defenders and critics evaluate instances of environmental governance on the criteria of effectiveness, participation, transparency and accountability. And, while these criteria are closely related to a democratic conception of the rule of law, they are only component parts. Presented as disconnected features, these evaluative criteria do not directly confront the potential for arbitrariness in environmental governance.

In the third Part, I argue that the alternative criteria found in the governance literature are not exhaustive of the rule of law. Rather, what governance scholars have missed by jettisoning the rule of law is the distinctive relationship that law constitutes between lawmaker and legal subject that explains why governance through law is something worth having. We will see that by reclaiming a focus on this relationship we are able to more precisely articulate the strengths - where governance attends to complexity and democratic deficiencies - and the concerns brought to light by the examples of environmental governance detailed in Part II.

\section{Part I. Old and New Governance}

New governance is, admittedly, a broad tent that does not easily lend itself to generalization. Governance — governing but without an emphasis on govern ment ${ }^{3}$ — promises to avoid the flaws of previous regulatory approaches: e.g., the perceived heavy-handedness and inefficiency of command-and-control regulation, and the questionable efficacy of market-based policy instruments or self-regulation. ${ }^{4}$ This part introduces the theory behind new governance.

${ }^{3}$ RAW Rhodes "The New Governance: Governing Without Government" (1996) 44 Political Studies 652.

${ }^{4}$ Mark S Winfield, "Governance and the Environment in Canada From Regulatory Renaissance to "Smart Regulation"" (2007) 17 Journal of Environmental Law and Practice 69 at 75 [Winfield], Lester M Salamon, "The New Governance and the Tools of Public Action: An Introduction" in Lester M Salamon ed, The Tools of Government: A Guide to the New Governance (Oxford: Oxford University Press, 2002) 1 at 15 [Salamon], John 
I argue that proponents of new governance tackle the complexity of contemporary regulatory problems. However, in doing so, they adopt a formal view of law, which they equate with command-and-control regulation. This leads them to dismiss the rule of law as irrelevant and posit that the nature of law itself is transforming in response to the proliferation of new governance measures.

\section{A. Responding to the Environmental Emergency and Rejecting the Formal Conception}

In light of its focus on regulatory complexity, new governance has been remarkably influential in the field of environmental law. Environmental law scholars frequently note that first-wave environmental laws have been effective at addressing many environmental issues. ${ }^{5}$ To be sure, Canadian environmental law does not have a glowing record on environmental protection-far from it. ${ }^{6}$ But there is a sense that much low hanging fruit has been picked and the problems that remain cannot be as easily addressed through uniform legal rules that target direct and concrete sources of environmental harm. ${ }^{7}$ For example, protecting Canada's water resources is no longer just about eliminating point source pollution, but addressing broader land use concerns with agriculture, groundwater aquifer depletion and invasive species. ${ }^{8}$ Species protection demands habitat preservation in resource-valuable areas, not just hunting

Braithwaite \& Ian Ayres, Responsive Regulation (Oxford: Oxford University Press, 1992) at 3 [Responsive Reg], Jody Freeman \& Daniel A Farber, "Modular Environmental Regulation" (2005) Duke L J 795 at $814 \mathrm{ff}$ [Modular Reg]. ${ }^{5}$ Neil Gunningham, Peter Grabosky, \& Darren Sinclair, Smart Regulation: Designing Environmental Policy (Oxford: Claredon Press, 1998) at 7 [Smart Regulation]. See Stepan Wood, Georgia Tanner, \& Benjamin J Richardson, "What Ever Happened to Canadian Environmental Law?" (2011) 37 Ecology L Q 981 for some success stories ["What Ever Happened"].

${ }^{6}$ David Boyd, Unnatural Law: Rethinking Canadian Environmental Law and Policy (Vancouver: UBC Press, 2003) at Chapter 1. "What Ever Happened", supra note 5.

${ }^{7}$ This is echoed at the international level: Smart Reg, supra note 5 at 7.

${ }^{8}$ Government of Ontario "Source Protection" online: <http://www.ontario.ca/environment-and-energy/sourceprotection>, Patricia Hania, "Climate Change and the Protection of Drinking Water in Ontario: An Opportunity to Adopt Adaptive Management?" (2011) 22 JELP 167. 
bans. And climate change mitigation and adaptation require coordination action amongst public and private actors at all levels of government.

First wave environmental laws are often associated with command-and-control regulation, typically legislation that prohibits specific causes of environmental degradation and comprehensively details what actions regulated parties must take to avoid environmental harm. ${ }^{9}$ The Forest Practices Code, ${ }^{10}$ the legislation that governed British Columbia forest practices at the time the beetle epidemic began, is an example of command-and-control regulation. The Code specified detailed requirements for harvesting of timber on Crown land. ${ }^{11}$ Proponents of new governance argue that command-and-control regulation is poorly suited to the kind of environmental problems we now face. ${ }^{12}$ They characterize environmental issues as scientifically uncertain and normatively complex; they do not lend themselves to clear a priori solutions. ${ }^{13}$ New governance advocates argue that command-and-control regulation seems to require an omniscient legislature which possesses the best, if not perfect, information about the problem and its possible regulatory solutions. ${ }^{14}$ The assumption, therefore, is that the legislature is able to set out in advance the appropriate 'command' to regulated entities. As we

\footnotetext{
${ }^{9}$ I adopt the moniker of command-and-control regulation, despite the fact that it originated as a derogatory term by its critics. The term "command-and-control regulation" is widespread in the fields of environmental law and new governance, so much so that it is even used by those with more neutral and sometimes favourable views of this form of regulation, despite its rather unflattering expression.

10 Forest Practices Code of British Columbia Act, RSBC 1996, c 159.

${ }^{11}$ Emily Walter, "Decoding Codes of Practice: Approaches to Regulating the Ecological Impacts of Logging in British Columbia" (2005) 15 JELP 143 [Walter].

${ }^{12}$ Command-and-control regulation has been heavily criticized, particularly in the American context where it has taken a highly prescriptive form not representative to the same extent of other jurisdictions: Neil Gunningham, "Environment Law, Regulation and Governance: Shifting Architectures" (2009) 21 J Envt'l L 179 at 191 ["Shifting Architectures"]. See Eric W Orts, "Reflexive Environmental Law" (1995) 89 Nw UL Rev 1227 at $1235-$ 1241 [Orts] for an overview of this criticism.

${ }^{13}$ Grainne De Burca, "New Governance and Experimentalism: An Introduction" (2010) 2010 Wis L Rev 227 at 232 [De Burca].

${ }^{14}$ Charles F Sabel \& William H Simon, "Epilogue: Accountability Without Sovereignty" Grainne De Burca, Joanne Scott eds, Law and New Governance in the EU and the US Hart Publishing, 2006) 395 at 398-9 ["Epilogue"] and David M Trubek \& Louise G Trubek, "New Governance \& Legal Regulation: Complementarity, Rivalry, and Transformation" (2007) 13 Columbia J of Eur L 539 at 542 [Trubek \& Trubek] (both sources summarize the major flaws with a command-and-control approach).
} 
have seen in previous chapters, the mountain pine beetle epidemic illustrated that, far from omniscient, legislators will instead be confronted with unforeseen events, some of which have catastrophic potential.

New governance scholars further argue that, even assuming the legislature has a solid epistemic foundation on which to base its decisions, command-and-control regulation is static and uniform. In their view, static rules do not promote anything more than minimal compliance and may be difficult to alter in light of changing information. ${ }^{15}$ Yet the environmental emergency makes clear that, in addition to their complexity, environmental issues are also dynamic — changing over time and space. Uniform rules are not well suited to environmental issues which seem to demand local modifications based on ecological context and continual revision and adaptation as problems - and our understanding of them-evolve. Moreover, the environmental emergency emphasizes the fact that this dynamism can also reveal the possibility of environmental catastrophe.

Finally, governance scholars note that command-and-control regulation is a poor fit with environmental issues that frequently spill over jurisdictional boundaries. ${ }^{16}$ This means that, under command-and-control regulation, many of those who suffer the environmental consequences had no opportunity to participate in making the decision and have no direct political recourse when they disapprove of the decision. New governance thus promises to improve accountability with respect to cross-border effects. ${ }^{17}$

\footnotetext{
${ }_{15}$ Smart Reg, supra note 4 at 45; Ortz at 1238-9.

${ }^{16}$ Epilogue, supra note 14 at 399; De Burca, supra note 13 at 233 (on interdependence).

17 Ibid. at 399.
} 
Critiques of command-and-control regulation are frequently overstated. Command-andcontrol regulation does not exist in an ideal form. As we saw in Chapter 3, it necessarily contains pockets of administrative discretion that allow administrative decision-makers to respond to the context of the regulatory problem. Command-and-control regulation is easily caricatured, however, because it aligns so nicely with the formal conception of the rule of law. ${ }^{18}$ The legislature is the source of legal norms, the exercise of administrative discretion is minimized, and, since the legislation contains such detail, its implementation can be straightforwardly enforced by the courts.

In contrast to the stodgy command-and-control model of regulation, new governance scholars focus on notions of "complexity, fragmentation, interdependencies, ungovernability, and the rejection of a clear distinction between public and private." 19 They offer up a range of policy instruments, such as public/private partnerships, negotiated rulemaking/regulationmaking, audited self-regulation, results-based rules, disclosure regimes, and decentralized and dynamic problem solving, that, when tailored to their specific context promise to be more effective and efficient than any linear approach to regulation. ${ }^{20}$ In its most decentred form, new governance would conceptualize administrative decision-making "as a set of negotiated relationships."21 On this view, the state is only one actor in any given governance network.

\footnotetext{
${ }_{18}$ McDonald, supra note 1 at 209 (noting the conflation of the rule of law with command and control regulation). 19 Julia Black, "Constructing and Contesting Legitimacy and Accountability in Polycentric Regulatory Regimes" (2008) 2 Regulation \& Governance 137 at 140 [Black]. See also Salamon, supra note 4 at 9-18 and Chris Tollefson, Anthony R Zito, \& Fred P Gale, "Symposium Overview: Conceptualizing New Governance Arrangements" (2012) 90 Public Administration 3 at 5 [Tollefson "Conceptualizing"].

${ }^{20}$ Orly Lobel, "The Renew Deal: The Fall of Regulation and the Rise of Governance in Contemporary Legal Thought" (2004) 89 Minn L Rev 342 at 345 [Lobel].

${ }^{21}$ Jody Freeman, "The Private Role in the Public Governance" (2000) 75 NYUL Rev 543 at 548 [Freeman].
} 
Complexity figures prominently in new governance. Governance scholars observe that contemporary regulatory problems are more challenging than in the past. They argue that the world is changing more rapidly and is more interconnected, which results in more unintended regulatory consequences. ${ }^{22}$ Contemporary problems seem more intractable. According to new governance scholars, under these regulatory conditions, the best we can do is put in place institutions and procedures that generate information, by enlisting a diverse range of participants, and institutionalizing flexibility to update existing approaches in light of changing information. ${ }^{23}$ They emphasize that complexity also creates opportunities for novel collaborations; an uncertain future destabilizes historically entrenched positions. ${ }^{24}$ By seizing on this opportunity, new governance mechanisms can respond to complexity in a way that command-and-control does not. They can reduce the range of the unforeseeable ${ }^{\square}$ and allow decision-makers to act on early warning signs.

In their enthusiasm for regulatory innovation, some proponents of new governance openly reject traditional rule-of-law constraints. ${ }^{25}$ They frankly acknowledge that new governance "disrespect $[\mathrm{s}]$ the distinction between enforcement and enactment." ${ }^{26}$ They advise

${ }^{22}$ Lobel, supra note 20 at 357-9. Gunther Teubner's work on reflexive law is important to note here. Teubner's diagnosis of the problems with regulation stems from his argument that law is only one system within a complex society (others include politics, religion, the economy, science). Since each system is normatively closed - that is, operates only according to its own logic - law cannot directly influence other subsystems. Legal regulation fails because it cannot perfectly dictate the operations of another system, or the opposite, it completely colonizes the other system. One need not wade too deeply in the intricacies of systems theory, however, to observe that there can be a fundamental mismatch between traditional legal regulation and complex societal problems. Indeed, much of the new governance and environmental governance scholarship that I refer to in this chapter does not adopt Teubner's perspective, although there are frequent parallels. See Gunther Teubner, "Substantive and Reflexive Elements in Modern Law" (1983) 17 Law \& Soc Rev 239 at 273-5.

${ }^{23}$ Lobel, supra note 20 at Part III, generally.

${ }^{24}$ Ibid. at 377-9.

${ }^{25}$ Epilogue, supra note 14 at 400.

${ }_{26}$ Ibid. 
lawyers and legal scholars to "get over it" $\square_{27}$ and find a way to play a constructive role in designing and implementing institutions and processes that are better tailored to respond to complex environmental issues. Even those with less forceful views concede that, in the new governance context, notions of legal legitimacy "will often be irrelevant, or at least unproductive... [and] will lead us to a dead end."28

The emergency framework, however, should sound a cautionary note to any approach that is so quick to jettison the rule of law in favour of necessity. As we saw, the law/emergency powers dualism was subject to both empirical and conceptual critiques, which we will now see have analogues in the environmental context.

\section{B. The Law/Governance Dualist Fiction}

Despite the forceful critique of command-and-control regulation, most governance scholars envision some role for formal law in regulating complex problems. Even those most critical of command-and-control regulation, concede that it can play a necessary and complementary role in a blend of policy instruments. ${ }^{29}$ Increasingly detailed empirical work on existing regulatory regimes shows that there is no simple trajectory from government to governance. ${ }^{30}$ Governance scholars argue that existing legal frameworks and institutions can be reconfigured to address complex environmental problems by linking together relevant

\footnotetext{
${ }^{27}$ Bradley C Karkkainen, "Collaborative Ecosystem Governance: Scale, Complexity, and Dynamism" (2002) 21 Va Envtl LJ 189 at 235 [Karkkainen], Mcdonald, supra note 1 at 208-209 (noting that regulatory scholars "sideline" the rule of law so that "we are left to get on with thinking about how the regulatory regimes we actually have can be modified and legitimated in line with our more fundamental political commitments.")

${ }^{28}$ Black, supra note 19 at 145 .

${ }^{29}$ Smart Reg, supra note 5 at 9; Responsive Reg, supra note 4 at 4.

${ }^{30}$ See, e.g. Tollefson "Conceptualizing", supra note 19 (and the articles cited therein); Cameron Holley \& Neil Gunningham, "Natural Resources, New Governance and Legal Regulation: When Does Collaboration Work?" (2011) 24 NZ U L Rev 309.
} 
administrative bodies and private parties. ${ }^{31}$ Novel collaborations may become the means for developing traditional legal regulation. ${ }^{32}$ Or traditional regulation may impose "default rules" to force recalcitrant stakeholders to the table in order to develop more flexible regulatory approaches. ${ }^{33}$ Governance scholars have observed that the coexistence of formal laws and novel governance techniques has resulted in hybridization; that is, "institutions whose very function or role has no precise analogue in prior legal regimes." $\square_{34}$

It seems, then, that the appropriate question is not how to categorize 'law' and 'governance' approaches to regulation, but rather what the proliferation of novel governance techniques means for the rule of law. Simon and Sabel, for example, speculate that we might be witnessing a transformation in the meaning of law itself. ${ }^{35}$ They suggest that we should understand law as a powerful mechanism for structuring relationships that enable problemsolving because the traditional view of law solely as a dispute-resolution and rights-protection mechanism is less useful in the face of such complex regulatory problems. ${ }^{36}$ On this view, both

31 "Modular Reg”, supra note 4.

${ }^{32}$ The American example of the Environmental Protection Agency's "Project XL" is frequently cited in the governance literature. As we will later see, the negotiations that concluded Great Bear Rainforest Agreement have been incorporated into formal forestry regulations.

${ }^{33}$ For example, in the United States, the strict prohibitions in the Endangered Species Act has led to the development of Habitat Conservation Plans, where environmentalists and landowners produce landscape-scale, multi-species management plans that allow landowners to take action that affects endangered species protection and would otherwise contravene the Act: Bradley C Karkkainen, "Information-forcing Regulation and Environmental Governance" Grainne De Burca, Joanne Scott eds, Law and New Governance in the EU and the US (Portland, OR: Hart Publishing, 2006) 293 at 301-304 ["Information-forcing"].

${ }^{34}$ Epilogue, supra note 14 at 396; Trubek and Trubek, supra note 14 (offering examples of "transformation"); David Trubek \& Louise Trubek, "World Turned Upside Down: Reflections on New Governance and the Transformation of Law, The" (2010) Wis. L. Rev. 719 at 721-2 ["Upside Down”](observe the common thread amongst new governance scholars is "a form of cognitive dissonance" from observing non-legal mechanisms of governance doing the traditional work of conventional legal institutions and processes).

${ }^{35}$ Epilogue, supra note 14 at 403-9. While Simon and Sabel are two who most clearly eschew the formal conception of the rule of law, we will see in Chapter 4 that their theory of democratic experimentalism is wholly compatible with the alternative democratic conception of the rule of law that I develop.

${ }^{36}$ On dispute resolution see William H Simon, "Toyota Jurisprudence: Legal Theory and Rolling Rule Regimes" Grainne De Burca, Joanne Scott eds, Law and New Governance in the US and the EU (Portland, OR: Hart Publishing, 2006) 37. On rights protection see Epilogue, supra note 14 at 407 (discussing workplace disability discrimination). This is not to say that dispute resolution and rights protection is unimportant in their view, simply that the way in which we go about achieving these goals has to change. 
law and governance are cut from the same cloth; they are both understood as instruments for resolving complex societal issues. The problem, we know from the emergency context, is that, by dismissing the relevance of the rule of law, there is no way to make it relevant again. If law is understood as nothing more than a tool of governance, it can be dispensed with at will. The appropriate questions, then, are whether such a transformation is indeed occurring, and if so, whether it adequately attends to rule-of-law concerns.

\section{Part II. Three Examples of Environmental Governance}

Much can fly under the banner of new governance and generalizations are difficult and not always helpful. From the new governance literature we have identified two hypotheses about environmental governance. In this Part, I test these two hypotheses against three concrete examples from the British Columbia forestry context. The examples selected display different characteristics of environmental governance. The Forest and Range Practices Act is the most tentative move toward environmental governance. It is results-based legislation that delegates significant autonomy to holders of forest licenses in the province. The Great Bear

Rainforest Agreement is an example of collaborative, ecosystem-based management in a particularly sensitive and controversial region of the province. The Forest Stewardship Council is a transnational certification body with no formal connection to provincial forestry regulation.

I argue that these examples support both hypotheses. First, the examples of environmental governance address the complexity of environmental problems and, in doing so, they depart in significant ways from the formal conception of the rule of law. Second, they demonstrate how mechanisms of new governance and traditional legal forms of regulation blur into one another to form novel forms of regulation. I also examine the existing academic 
commentary on these three examples and argue that it has only indirectly addressed the ruleof-law concern for arbitrariness. Instead, existing commentary has focused on alternative criteria of effectiveness, participation, transparency and accountability.

\section{A. Results-Based Regulation}

In the aftermath of the beetle epidemic, the province enacted a radical change in its approach to regulating forest practices in the province. The Forest and Range Practice Act (FRPA), ${ }^{37}$ results-based regulation, replaced the Forest Practices Code, a command-and-control statute. Both statutes were enacted to regulate forest practices (e.g. the use of clear-cutting, placement and construction of logging roads, location of harvesting) in order to ensure better protection of non-timber forest values, such as biodiversity, water quality and aesthetics, while maintaining timber harvest. The previous Code was criticized as "heavy-handed" by industry, since it imposed detailed planning requirements on companies, but its watered down implementation meant that it also fell short of many of its environmental promises. ${ }^{\square}$ The FRPA was promoted as legislation that would achieve the same objectives as the Code while allowing companies flexibility over how to meet those objectives. ${ }^{\square 9}$ The legislation is typically characterized as results-based regulation because it sets out regulatory objectives without prescribing how regulated parties must achieve these objectives, but it also blends these results with planning requirements. It is therefore a combination of results-based and managementbased regulation.

\footnotetext{
${ }_{37} \mathrm{SBC}$ 2002, с 69 [FRPA].

38 Walter, supra note 11 at $156-7$.

39 The regulation sets out some mandatory practices to prohibit high-risk activities (e.g. damage to stream banks and fish habitat, causing of landslides), but all other practices are to be specified by the companies in their plans: Forest Planning and Practices Regulation, BC Reg 14/2004 ss35-40 [FPP Regulation].
} 
In brief, the FRPA incorporates overarching qualitative objectives — such as protecting wildlife, the productivity and hydrological function of soils, and conserving the cultural heritage resources of forests ${ }^{\square}$ - and requires that companies draft and submit Forest Stewardship Plans for approval by the Minister before carrying out any forestry activities. ${ }^{\square_{11}}$ The plans must detail "results or strategies" that disclose how the proposed activities will be consistent with the overarching performance-objectives. ${ }^{42}$ The plans are the only major regulatory requirement for license holders prior to harvesting timber and the grounds on which the plan can be rejected are very limited. ${ }^{43}$ The plans are open to public comment ${ }^{\square}$ and they must be revised and reapproved every 5 years. ${ }^{\square}$ Forest companies, therefore, have considerable autonomy over their forest practices in exchange for relatively modest approval and reporting requirements. $\square^{\square}$

The FRPA operates through a combination of legislated requirements, regulations, orders in council and administrative discretion that differ only by a matter of degree from the environmental regulation we saw in Chapter 3. At the same time, it demonstrates a clear shift away from the state as the centre of governance, and instead places much of the heavy-lifting on the regulated parties. The 'command,' it might be said, is for the regulated party to develop

\footnotetext{
${ }^{40}$ FRPA, supra note 37 s 149, FPP Regulation, supra note 39 ss 5-10. The FRPA contains additional planning requirements such as site plans (s 10) and woodlot plans (s 12), but these do not require public consultations.

${ }^{41}$ FRPA, supra note $37 \mathrm{~s} 3$ (before harvesting any timber or constructing any road).

${ }^{42}$ Ibid. s 5.

43 Ibid. s 6.

${ }^{44}$ FPP Regulation supra note 39 at ss $20-22$.

${ }^{45}$ FRPA, supra note 37 at s 6 (although they can be renewed for up to an additional 5 years). Companies are required to produce further, detailed site plans prior to conducting specific operations, though these do not require government approval and only need be made public upon request: Ibid at ss 10-11.

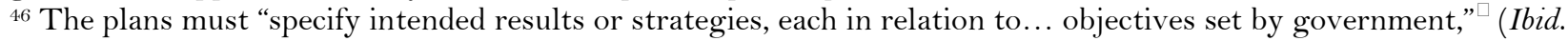
s 5(1)(b)) such as how the company will "conserve, at the landscape level, the water quality, fish habitat, wildlife habitat and biodiversity associated with those riparian areas." (FPP Regulation, supra note 39 at s 8).
} 
its own set of rules for how to conduct forest practices. ${ }^{47}$ Private parties are therefore key players in the specification of public objectives and their delivery, with the Forest Stewardship Plans acting as the linkages in a network of forest governance across the province.

By stepping away from traditional command-and-control regulation, the FRPA promises, in some respects, to respond to the complexity of forest management. In principle, it harnesses the tremendous information and expertise of forest companies by allowing them to develop individualized, context-specific rules for their forest practices. ${ }^{48}$ Plans are subject to public scrutiny and companies are required to seek re-approval to ensure the plans reflect upto-date knowledge, incorporate lessons learned, and improve their performance.

Proponents of results-based regulation highlight the gains in both effectiveness and efficiency.49 By legislating for environmental results and giving companies flexibility over the means, results-based regulation recognizes that individual companies operate in different ways that create different risks. Individualized rules developed by the companies, they argue, will be more rational in this sense. ${ }^{50}$ Proponents maintain that results-based regulation also promotes innovation and responds more quickly to emerging threats. ${ }^{51}$ Indeed, the FRPA was introduced as a way of stimulating innovation in forest practices that can be replicated when effective. All

\footnotetext{
47 "Information-Forcing", supra note 33 at 295 (on how hybrid public-private institutional collaborations are the "most significant instantiation of new governance in contemporary US environmental regulation."). The $F R P A$ comes close to what Braithwaite and Ayers describe as enforced self-regulation, which requires individual firms to generate their own rules that are then publicly ratified and both privately and publicly enforced: Responsive Reg, supra note 4 at Chapter 4.

${ }^{48}$ Cary Coglianese, Jennifer Nash, \& Todd Olmstead, "Performance-Based Regulation: Prospects and Limitations in Health, Safety and Environmental Protection" (2003) 55 Admin L Rev 704 at 714 [Coglianese \& Lazar]; Cary Coglianese \& David Lazer, "Management- Based Regulation: Prescribing Private Management to Achieve Public Goals" (2003) 37 Law \& Society Rev 691 at 706 [Coglianese et al]; Smart Reg, supra note 5 at 52 (on self regulation); Responsive Reg, supra note 4 at 104-105 (on how firms are often more capable - though not necessarily more willing - to develop and enforce rules).

${ }^{49}$ Coglianese et al, supra note 48 at 701; Smart Reg, supra note 5 at 15.

${ }^{50}$ Responsive Reg, supra note 4 at 110.

${ }^{51}$ Coglianese et al, supra note 48 at 711, Responsive Reg, supra note 4 at 110-112.
} 
this means that (in principle) results-based regulation will achieve the same or better environmental results as command-and-control regulation at less public expense.

As it turns out, however, the FRPA has been roundly criticized as thinly-veiled deregulation that cannot, even charitably, be understood as a genuine attempt to meet the stated performance-objectives. ${ }^{52}$ Indeed, critics have noted that the British Columbia legislature failed to heed the warnings of regulatory scholars who argue that the effectiveness of performance- and management-based regulation depends on monitoring and enforcement capacity. The very conditions that make command-and-control regulation difficult also make it difficult to specify measurable goals, and for regulators to monitor and enforce planning requirements. ${ }^{53}$ Yet the province's move to the FRPA coincided with deep cuts to the Ministry of Forests which reinforced critics' views that 'results-based legislation' was deregulation in disguise.

Both the defence and criticism of results-based regulation has been framed predominantly in terms of effectiveness. ${ }^{54}$ Critics primarily try to meet proponents on their own terms by arguing that, when implemented, results-based regulation frequently departs from the ideal model. Adopting this perspective, Walter writes:

“The FRPA appears weakly designed from this point of view, as the outputs are vague and difficult to measure, the mechanisms for monitoring and assessing them are not

\footnotetext{
${ }_{52}$ Many environmental NGOs boycotted the consultation process: British Columbia, Legislative Assembly, Official Reports of Debates (Hansard), $37^{\text {th }}$ Parl, $2^{\text {nd }}$ Sess, Vol 10 No 3 (6 Nov 2002) at 4344 (Hon de Jong).

${ }_{53}$ Coglianese \& Lazar, supra note 48 at 726.

${ }^{54}$ Coglianese et al, supra note 48 at 714 (Determining whether performance-based measures are effective requires is difficult empirical work, which currently does not exist). See also: Julie Williams, "The Design of PerformanceBased Natural Resource Regulation: Lessons from the B.C. Experience" (2005) 18 CJALP 61.
} 
well defined or resourced, and incentives for firms to ensure that stated environmental protection goals are met are weakened by prescribed exclusions from liability...." 55

In short, Walter and others argue that the FRPA simply will not work. ${ }^{56}$

Walter further critiques the FRPA as an example of neoliberal ideology that is inconsistent with environmental protection. ${ }^{57}$ She argues that the FRPA reflects the logic "that industry must play the role of regulator and producer if it is to be globally competitive, and government's oversight role must be further reduced.” ${ }^{58}$ Forest companies are accordingly given the pivotal role in regulation and the perspective of the company is privileged in any evaluation of the merits and weaknesses of any given regulatory approach. ${ }^{59}$ Intriguingly, she suggests that the shift to environmental governance requires us to pay closer attention to the “interconnections between structural, institutional and normative dimensions of a regulatory system... including changing patterns of private authority." 60 But she does not elaborate on what she means by this, nor does she suggest that the concept of the rule of law or legality could be of any assistance in working this out. ${ }^{61}$

While largely framed in terms of effectiveness, distinctly rule-of-law concerns arise from this picture of the FRPA. The legislation allows private parties to effectively write, rewrite and interpret the rules without guarantees that these private forest plans will align

\footnotetext{
55 Walter, supra note 11 at 178 . Also noted by critics is the fact that the Act and regulations prioritize timber values over other forest values: Walter, supra note 11 at 173-4; Cutting up the Safety Net: Environmental Degradation in British Columbia (Vancouver: West Coast Environmental Law Association, 2005) at 22 [Safety Net].

${ }_{56}$ We return to the problems with the FRPA in the next chapter in order to understand how it can be made consistent with the rule of law.

57 Walter, supra note 11 at 183-4 and Stepan Wood, "Environmental Management Systems and Public Authority in Canada: Rethinking Environmental Governance" (2002) 10 Buff Envt'l LJ 129 at 188 [Wood].

${ }_{58}$ Walter, supra note 11 at 181.

59 Ibid. at 180 .

60 Ibid. at 183 .

${ }^{61}$ Indeed, to the contrary, her only reference to "legality" suggests that she would likely view any recourse to the rule of law with deep suspicion (Ibid. at 185).
} 
with public values. ${ }^{62}$ In practice, the plans may be public-spirited, but existing mechanisms do not protect against arbitrariness. Public scrutiny prior to approval is minimal. ${ }^{3}$ The FRPA further delegates the approval function to professional foresters, rather than public officials. ${ }^{64}$ And, in light of the vaguely worded legislative objectives, there seems to be no meaningful role that a court could play in ensuring they are met. ${ }^{65}$

\section{B. Ecosystem-Based Management}

The Great Bear Rainforest Agreement (GBRA) is a more creative experiment in environmental governance. Unlike the FRPA, it is generally regarded as an environmental governance success story. ${ }^{\square 6}$ The GBRA is the product of a highly contentious land use planning process for an ecologically-sensitive region of British Columbian forest. ${ }^{67}$ These regions, collectively known as the Great Bear Rainforest, were the subject of an international environmental campaign to prohibit timber harvesting in old growth forest. They are also home to dozens of First Nations with unresolved title claims.

\footnotetext{
${ }^{62}$ Epilogue, supra note 14 at 397-8 ("The deep worry here is that the explicit provisionality of new governance framework laws obligates those who 'follow' the legal rules to re-write them in the act of applying them; that this revision is at the discretion of those who do the revising; and that this inevitable exercise of discretion is incompatible with the kinds of accountability on which citizens of a democracy rightly insist...)

${ }^{63}$ Forest Practices Board, Board Bulletin Volume 15: Public Involvement in Forest Management Planning in BC (Victoria: Government of British Columbia, 2013) at 3.

${ }^{64}$ FRPA, supra note 37 at s 16(1.01).

${ }_{65}$ The fact that the Act requires approval so long as the plans formally comply with the legislation and regulations would also preclude review: Ibid. at s 16 .

${ }^{66}$ Merran Smith and Darcy Dobell, Place of Power: Lessons from the Great Bear Rainforest (Vancouver: Tides Canada Foundation, 2010) [Smith \& Dobell]; Karen Price, Audrey Roburn, \& Andy MacKinnon, "Ecosystem-Based Management in the Great Bear Rainforest" (2009) 258 Forest Ecology and Management 495; Gordon McGee, Andrea Cullen, \& Thomas Gunton, "A New Model for Sustainable Development: A Case Study of the Great Bear Rainforest Regional Plan" (2010) 12 Environ Dev Sustain 745. It is referred to as the Great Bear Rainforest because it is home of the iconic Spirit Bear.

${ }^{67}$ Michael Howlett, Jeremy Rayner, \& Chris Tollefson, "From Government to Governance in Forest Planning? Lessons from the Case of the British Columbia Great Bear Rainforest Initiative" (2009) 11 Forest Policy and Economics 383 at 388 [Howlett et al].
} 
The story of the GBRA is both fascinating and complex. ${ }^{\square}$ The GBRA is a product of decades of conflict followed ultimately by collaboration between government, industry, environmental groups and First Nations. The 2006 agreement contains four pillars for managing the region, two of which are relevant for present purposes. ${ }^{69}$ The GBRA sets out principles of ecosystem-based management for determining appropriate harvest practices in the unprotected, harvestable area of the region. ${ }^{\square}$ Ecosystem-based management is a significant departure from the sustainable yield approach discussed in Chapter $3 .^{\square}$ Where sustainable yield places the focus on maximizing the extraction of timber over time, ecosystem-based management is centred on the maintenance of ecological health or integrity. Ecosystem-based management, as the GBRA describes it, strives to "maintain those spatial and temporal characteristics of ecosystems such that component species and ecological processes can be sustained and human well-being supported and improved." ${ }^{2}$ The Agreement also creates a shared decision-making body, the Joint Land and Resource Use Forum, that is co-chaired by government officials and First Nations representatives, and which oversees the implementation of ecosystem-based management. ${ }^{\square} 73$

\footnotetext{
${ }^{68}$ See Smith \& Dobell, supra note 66 for an overview of the Agreement itself, in addition to the backstory of how it was concluded. Howlett et al, supra note 67 discusses the relationship between the Agreement and formal government processes.

69 The other two: it creates a network of protected areas covering one-third of the total area where logging is prohibited and creates the 'Coast Opportunities Funds,' which support ecosystem-based management research and monitoring, and sustainable economic activities for First Nations communities (Smith \& Dobell, supra note 66 at 32, 36-7.)

${ }^{70}$ The harvestable region is divided into different scales and categorized based on high, medium or low-priority to which different management agreements apply. Ibid. at 34 .

${ }^{71}$ Howlett, supra note 67 at 388, Tollefson FSC, supra note 2 at 189.

${ }^{72}$ Nanwakos Council Coastal First Nations \& Lands Natural Resource Operations, Ecosystem Based Management on $B C^{\prime}$ s Central and North Coast (Great Bear Rainforest) (Victoria: Government of British Columbia, 2012) at 5 [EBM Manual].

${ }^{73}$ Smith \& Dobell, supra note 66 at 38. ("It oversees technical and scientific work, identifies research priorities, and makes policy and management recommendations to the province and the First Nations.”)
} 
In the years since the GRBA was reached, its terms have been incorporated into the FRPA as "objectives” that must be accounted for in companies' Forest Stewardship Plans, ${ }^{\square_{74}}$ as discussed above. In subsequent years, the Joint Forum has continued to negotiate the implementation of ecosystem-based management practices. ${ }^{\square}$ This includes an ongoing commitment to adaptive management, which requires the Joint Forum to continually monitor the region with the aim of continual improvement of forest practices. ${ }^{\square}$

The GBRA has been previously analyzed from the perspective of new governance. ${ }^{77}$ These analyses unpack the intricate interdependence between formal policy-making mechanisms and informal network arrangements. The GBRA departs from command-andcontrol regulation in three significant ways. First, the GBRA is not a product of top-down policy development, but rather the result of complex multi-party collaboration that originated outside any formal legal framework. ${ }^{78}$ Second, the basis of these negotiations was ecosystembased management, principles and indicators developed by an independent team of scientists that comprehensively address the range of environmental issues in the region and that emphasize the need for continued learning and adaptive management. In other words, the GBRA does not set down fixed rules but rather context-sensitive, flexible principles. Third, the agreement maps onto the scale of the ecosystem and addresses problems holistically. That is, it

\footnotetext{
${ }^{74}$ But see critique of the FRPA above, which casts some doubt on how meaningful the effect of the land use plans are in the context of forest practices: See also Howlett et al, supra note 67 at 388-9.

75 The deadline for this was March 31 2014: EBM Manual, supra note 72 at 4. The deadline was extended to Dec 31 2014. See "Environmental Organizations Welcome Province and First Nations Great Bear Rainforest Commitments" Save the Great Bear (31 March 2014) Online: <http://www.savethegreatbear.org/>. I was unable to find an update on whether this deadline has been met.

76 EBM Manual, supra note 72 at 9.

${ }^{77}$ Howlett et al, supra note 67, Kaisa Raitio \& Heli Saarikoski, "Governing Old-Growth Forests: The Interdependence of Actors in Great Bear Rainforest in British Columbia" (2012) 25 Society \& Natural Resources: An International Journal 900.

${ }^{78}$ Howlett et al, supra note 67 at 388
} 
addresses a complete set of regional issues, so that for example, ameliorating one threat to the Great Bear Rainforest does not aggravate another. ${ }^{79}$

The GBRA is a dramatic shift from traditional environmental regulation in that it attempts to address complexity in every aspect of its institutional design. It covers an impressive geographic scope, combines scientific expertise with collaborative decision-making by representative interests, commits to ongoing monitoring and learning, and integrates these decisions with the broader regulatory framework for forestry and land use planning in the province.

Much existing work on ecosystem governance focuses on water management, but highlights similar merits. Proponents argue that ecosystem governance promises to be more effective than command-and-control because it makes decisions at an ecologically appropriate scale. ${ }^{80}$ It brings all 'users' of the ecosystem to the table to address harms comprehensively, and enables ongoing monitoring and adjustment based on past learning and changing ecological conditions. ${ }^{81}$

Proponents emphasize the participatory aspects of collaborative, ecosystem governance. For example, Brandes et al emphasize "the need for meaningful stakeholder participation to

\footnotetext{
${ }^{79}$ Joint Land and Resource Forum, Terms of Reference (Dated for Reference the 7th day of February, 2008) [copy on file with author].

${ }^{80}$ Karkkainen, supra note 27 at $212 \mathrm{ff}$; Bradley C Karkkainen, "New Governance” in the Great Lakes: Has Its Time Arrived?" (2006) 2006 Mich St L Rev 1249; Jamie Benidickson, "The Great Lakes and the Mediterranean Sea: Ecosystem-Management and Sustainability in the Context of Economic Integration" (2004) 14 JELP 107.

${ }^{81}$ Karkkainen, supra note 27 at 218-9; Oliver M Brandes, Keith Ferguson, Michael M'Gonigle, and Calvin Sandborn, At a Watershed: Ecological Governance and Sustainable Water Management in Canada (Victoria: POLIS Project on Ecological Governance, 2005) at iv [Brandes et al]; "Modular Reg," supra note 4.
} 
improve decision making and create more durable results..." 82 But even proponents of environmental governance concede there are challenges here. ${ }^{83}$ 'Stakeholder participation' does not equal genuine collaboration. Tough questions thus remain about how to move beyond backroom, interest group bargaining to a more deliberative decision-making process. Many proponents suggest that law ought to play a procedural role to enhance participation and prevent interest-group capture, but they offer no real details. ${ }^{84}$

Critics seize on these ambiguities. They reiterate the argument that only certain groups can be represented in the decision-making process and it is not always clear how they are selected or whether they are representative of the general public. ${ }^{85}$ They further point out that, when ecosystem-based management principles are developed by independent experts, these experts are not directly accountable to the public. ${ }^{86}$ Critics also argue that the transparency of collaborative governance is a fundamental issue. ${ }^{87}$ While the decision-making process may be transparent to those parties internal to the process, it may be utterly opaque to those outside. Indeed, detailed information about the Joint Forum and ongoing implementation of the GBRA is not easily accessible to the general public. ${ }^{88}$ Some proponents of environmental governance argue that formal laws - presumably, such as the FRPA — can play a residual role in ensuring

\footnotetext{
${ }^{82}$ Brandes et al, supra note 81 at 19.

${ }^{83}$ Karkkainen, supra note 27 at 239.

${ }^{84} \mathrm{Ibid}$. at 236, Farber and Freeman offer more details here. They argue that the combination of traditional participation through notice-and-comment with an innovative stakeholder advisory council and informal participation with individual admin agencies represents an improvement on the traditional approach: "Modular Reg", supra note 4 at 895-6.

${ }^{85}$ Black, supra note 19 at 143 .

${ }^{86}$ Bruce Pardy, "Ecosystem Management in Question: A Reply to Ruhl" (2006) 23 Pace Envtl L Rev 209 at 217 [Pardy].

${ }_{87}$ Martin Shapiro, "Administrative Law Unbounded: Reflections on Government and Governance" (2000) 8 Ind J Global Legal Stud 369 at 372-3 [Shapiro].

${ }_{88}$ Supra note 75.
} 
basic public accountability. ${ }^{89}$ But such a claim is unpersuasive given how far this model of environmental governance departs from the formal conception. ${ }^{90}$

Many critics also question the claims that collaborative ecosystem management is more effective than conventional regulation. They point out that ecosystem management approaches typically require considerable autonomy from formal legal frameworks to allow for genuine collaboration amongst participants. There is thus no guarantee that environmental protection will prevail. Indeed, it is notable that the principles of ecosystem-based management set out in the GBRA departed from those proposed by the team of independent scientific experts. ${ }^{91}$ Critics further worry that adaptive management requires an ongoing effort and commitment amongst participants that is not often sustainable. ${ }^{92}$

Amongst all these debates about effectiveness, participation and transparency, Bruce Pardy makes a rare contribution by directly questioning the rule-of-law credentials of ecosystem management. He argues that ecosystem management is one of the worst offenders in environmental law. ${ }^{93}$ Unlike judges, he argues, ecosystem "managers" are not required to give reasons, adhere to precedent, and are not subject to appeal. ${ }^{94}$ Indeed, consistent with Pardy's general critique, the Joint Forum of the GBRA does not offer written reasons for its decisions. It is under no requirement to be consistent, indeed, adaptive management may demand the

89 "Modular Reg", supra note 4 at 905.

90 Shapiro, supra note 87; Black, supra note 19 at 143 (noting the "many hands problem" meaning that it is not clear which of the parties in the network is responsible for which aspects of the regulation).

${ }^{91}$ Pardy, supra note 86; Annecoos Wiersema, "A Train without Tracks: Rethinking the Place of Law and Goals in Environmental and Natural Resources Law" (2008) 38 Envtl L 1239.

92 Ibid. at 1297-8.

93 Bruce Pardy, "The Pardy-Ruhl Dialogue on Ecosystem Management Part V: Discretion, Complex-Adaptive Problem Solving and the Rule of Law" (2008) 25 Pace Envtl L Rev 341 at 353. Pardy's definition of environmental management shares with the GBRA the features of science-based, discretionary decision-making that incorporates principles of adaptive management.

${ }^{94}$ Ibid. at 347 
opposite. There was no mechanism for outsiders to directly influence the development of the GBRA. And, as we have seen, successful judicial review of a Forest Stewardship Plan seems unlikely given the language of the FRPA.

Pardy highlights the problem of arbitrariness in environmental decision-making and the essential role that the rule of law plays in curbing arbitrary decisions. As we saw in the previous chapter, however, his adherence to the formal conception does not provide an adequate solution. Nonetheless, he is right to point out that, by focusing on proving (and improving) the effectiveness and accountability of ecosystem management, its defenders have not directly confronted the deeper risk of arbitrariness.

\section{Transnational Certification}

Forest certification is a third example of policy innovation in British Columbia forestry and it takes environmental governance to a transnational level. ${ }^{95}$ Numerous forest certification programs are represented in the British Columbia forest industry, but the Forest Stewardship Council (FSC) standard is renowned as "the most rigorous in protecting environmental values." ${ }^{96}$ The standards developed through the FSC demonstrate a different response to the limitation of the command-and-control regulatory model. It circumvents the state altogether.

The FSC is a transnational organization comprised of non-state actors. It develops standards for environmentally appropriate, socially beneficially and economically viable forest operations. ${ }^{\square}$ By adhering to FSC standards, forest companies gain the right to affix the FSC

\footnotetext{
${ }^{95}$ See also Wood, supra note 57 (on ISO 140001 standards).

${ }_{96}$ Tollefson FSC, supra note 2 at 188.

${ }^{97}$ Forest Stewardship Council online: <https://ic.fsc.org/vision-mission.12.htm>.
} 
label to their products. This allows consumers "to act on their environmental and social preferences." ${ }^{98}$ Having succeeded in their market-based campaign that led to the GBRA, British Columbian forest stakeholders turned to the FSC. ${ }^{99}$ They developed a BC-specific FSC standard which was first implemented in 2005.

Forest certification differs from the previous two examples in two significant respects. First, the FSC is a transnational organization comprised entirely of non-state members. The FSC prohibits membership of state actors; rather, it is comprised of private entities, civil society groups, international organizations and interested individuals. ${ }^{\square} 100$ Members are allocated to one of three chambers - environment (e.g. environmental groups), social (e.g. labour unions), economic (e.g. forest companies). Each chamber holds one-third of the vote and a supermajority of two chambers is required to pass resolutions on FSC policy, such as changes to the standards or criteria for certification. ${ }^{\square 101}$ The second key difference is that both membership and adherence to the FSC standards is voluntary. Any non-governmental organization or individual who agrees to the FSC's mission can become a member. ${ }^{\square}{ }^{102}$ And any company that adheres to FSC standards can become certified. ${ }^{103}$ Certification is often referred to as the carrot that incentivizes good practices, ${ }^{\square} 104$ as opposed to the stick of boycotts or the sanctions attached to command-and-control regulation.

98 Tollefson FSC, supra note 2 at 19.

${ }_{99} \mathrm{Ibid}$. at 190 (describing the FSC as a "timely and unique venue to promote broader and more creative dialogue about the future of sustainable forest management in British Columbia.")

${ }^{100}$ Forest Stewardship Council, online: <https://ic.fsc.org/become-a-member.63.htm>.

101 Tollefson FSC, supra note 2 at 27-8.

102 Ibid. at 276.

${ }^{103}$ Where a regional standard does not exist, the certifier is free to develop or adapt the international standards to suit the local context: Ibid. at 32 .

${ }^{104}$ Benjamin Cashore, "Legitimacy and the Privatization of Environmental Governance: How Non-State MarketDriven (NSMD) Governance Systems Gain Rule-Making Authority" (2002) 15 Governance 503 at 507 [Cashore]. 
Like the GBRA, the FSC elaborates principles of ecosystem-based management. The FSC contains 10 guiding principles. For example, Principle 6 is "to maintain or restore the ecosystem, its biodiversity, resources and landscapes." ${ }^{105}$ Each principle contains measurable and verifiable criteria that specify how those principles are to be achieved, such as by conducting an impact assessment prior to beginning any forestry activities. ${ }^{\square}{ }^{106}$ Where regional standards have been developed, as is the case in British Columbia, these standards further specify the criteria to suit the local context. The British Columbia standard is unique, for example, in its requirement that harvesting practices must fall within a "range of natural variability." ${ }^{107}$ Since British Columbian forests currently grow in unevenly-aged stands, this significantly limits clear-cut harvesting without uniformly banning its use. ${ }^{\square} 108$

The FSC has attracted a huge amount of academic interest as a particularly successful example of global governance. ${ }^{109}$ At present, the organization has over 800 members and has certified forests in 81 countries worldwide. ${ }^{110}$ It promises to address the complex problem of sustainable forestry at both a global and regional level by linking the central, international institution with local standard bodies. ${ }^{111}$ The FSC takes a holistic perspective on the problem by treating environmental, social and economic concerns as interconnected. As a self-

\footnotetext{
${ }^{105}$ Forest Stewardship Council, online: <https://ic.fsc.org/principles-and-criteria.34.htm>.

106 Forest Stewardship Council Regional Certification Standards for British Columbia (Forest Stewardship Council, 2005) at 6.2, online: FSC-Canada < https://ca.fsc.org/bc-standard.202.htm>.

${ }^{107}$ See, e.g., Ibid. at 6.3.7, 6.3.8 and 6.3.10.

108 Tollefson FSC, supra note 2 at 195-6, 206

109 Errol Meidinger, "The Administrative Law of Global Private-Public Regulation: the Case of Forestry" (2006)

17 Euro J of Int'l L 47 at 77-8 [Meidinger] (noting the rapid proliferation of forest certification worldwide and how it is effecting forest regulation).

${ }^{110}$ Forest Stewardship Council online: <https://ic.fsc.org/20th-anniversary.756.htm>.

${ }^{111}$ Christine Overdest \& Jonathan Zeitlin, "Assembling an Experimentalist Regime: Transnational Governance Interactions in the Forest Sector" (2014) 8 Regulation \& Governance 22.
} 
consciously deliberative body with global reach, it has the capacity to aggregate and generate a huge amount of information about the state of forest management worldwide. ${ }^{112}$

The FSC is also a clear break from command-and-control regulation and the formal conception of the rule of law. Meidinger describes forest certification as "a multi-centred private/public [system], which operates in a loosely coordinated and sometimes disjointed fashion." ${ }^{113}$ And as an example of market-based or private governance, ${ }^{114}$ its authority seems to come from the market, not law. At the same time, however, the FSC grapples with a public problem — global sustainable forestry — and purports to represent and act in the public interest. It operates through a highly sophisticated architecture that mirrors elements of a federalist, Parliamentary system. ${ }^{15}$ Commentators have argued that the FSC has effectively created a "global forest polity." ${ }^{16}$ And the FSC now influences domestic forest policy in tangible ways such that it cannot be considered as isolated from state-sanctioned forest practices. ${ }^{117}$

Errol Meidinger has argued that environmental certification is a novel form of administrative law because it carries out essentially the same standard-setting and licensing functions as domestic regulatory bodies. ${ }^{118}$ Because of the networked arrangement of forest

\footnotetext{
${ }_{112}$ Moreover competition between different forest certification bodies reveals strengths and weaknesses from which all organizations have learned and improved: Meidinger, supra note 109 at 78 .

${ }^{113} \mathrm{Ibid}$. at 48. See also Wood, supra note 57 at 187.

${ }^{114}$ Cashore, supra note 104; Graeme Auld, Constructing Private Governance: The Rise and Evolution of Forest, Coffee, and Fisheries Certification (New Haven: Yale University Press, 2014); "Shifting Architectures", supra note 12 at 197 (referring to it as “civil regulation”).

115 Tollefson FSC, supra note 2 at Chapter 12.

116 Ibid. at 307.

${ }^{117}$ Meidinger, supra note 109 at 59 (noting its effects on public procurement policies and state-owned forests receiving certification).

$118 \mathrm{Ibid}$. at 60. Although he does not reference it, Meidinger's research on forest certification fits into the broader literature on global administrative law. See: Benedict Kingsbury, Richard B Stewart, \& Nico Krisch, "The Emergence of Global Administrative Law" (2005) 68 Law \& Contemporary Problems 15 [Stewart et al]. Tollefson et al understand the FSC on somewhat similar terms, by arguing that it is roughly analogous to a liberal-constitutional state. But the extent of their legal analysis of FSC standards is to label them as "soft law" but leaning toward hard law because the only avoidance option is to exit: Tollefson FSC, supra note 2 at 299-300.
} 
certification, however, he rejects "simplistic source-of-law models for understanding administrative law." 119 Instead he evaluates forest certification on the basis of alternative received criteria for evaluating domestic administration: criteria of effectiveness, accuracy and accountability. ${ }^{120} \mathrm{He}$ concludes, consistent with the general tide of opinion, that the FSC is highly effective, ${ }^{121}$ though the particularities of the forest products market raise some risks about the reliability of forest certification. ${ }^{122}$

When Meidinger turns to the FSC's accountability, however, he encounters some difficulty. He argues that accountability implies a principal-agent relationship and thus encourages a focus on individual accountability relationships, "when in fact accountability mechanisms are cumulative and interactive." ${ }^{23}$ The FSC must be accountable to its members, the companies it certifies, and the general public on whose behalf it purports to act. But it also contains further internal networks between, e.g., national or regional standards bodies, thirdparty certifiers, companies and local stakeholders. ${ }^{124}$ The difficulties of assessing multiple accountability mechanisms leads Meidinger to turn to accountability "proxies," which he identifies as transparency and participation. ${ }^{125}$

\footnotetext{
119 Meidinger, supra note 109 at 49.

120 Ibid. at $76 \mathrm{ff}$.

${ }^{121} \mathrm{Ibid}$. at 78-9; Tollefson FSC, supra note 2 (on the rigour of the BC standard). But for some caveats see: Axel Marx \& Dieter Cuypers, "Forest Certification as a Global Environmental Governance Tool: What Is the MacroEffectiveness of the Forest Stewardship Council?" (2010) 4 Regulation \& Governance 408; Stephen Bell \& Andrew Hindmoor, "Governance Without Government? The Case of the Forest Stewardship Council" (2012) 90 Public Admin 144; Emily Walter, "From Civil Disobedience to Obedient Consumerism? Influences of Market-based Activism and Eco-certification on Forest Governance" (2003) 41 Osgoode Hall L J 531 (questioning some of the assumptions underlying the market-based approach).

${ }^{122}$ Meidinger, supra note 109 at 80 (noting the information asymmetry between the consumer and producer, which means the key to reliability is in the certifiers. This creates the risk of corruption within the certification scheme.)

${ }^{123} \mathrm{Ibid}$. at 81.

${ }^{124}$ Ibid. at 83. It is all of these at the same time.

${ }_{125}$ Ibid. at 81
} 
On its face, forest certification would seem to fair well in terms of transparency. Indeed, its very purpose is to clearly identify for consumers which forest products are sustainable. But Meidinger and others observe that certification practices can actually obscure forest practices. ${ }^{126}$ They render a complex and political problem manageable through a set of seemingly technical compliance standards where auditors simply tick 'yes' or 'no.' These audits and third-party auditors can act as a buffer that prevents governments or the public from really scrutinizing the nature of the problem. Stepan Wood argues that law must therefore act "as a 'border guard' to define and protect certain 'public' stakes” of management standards by "requiring public consultation and transparency in the setting, monitoring and review of environmental performance." 127

Despite the absence of domestic or international law to which Wood refers, the FSC is highly transparent and participatory. ${ }^{128}$ Its membership is open to all who subscribe to its mission. Its policies are deliberated upon within and across the chambers and are subject to public notice-and-comment proceedings. ${ }^{129}$ FSC principles and criteria require auditors to consult with local stakeholders when conducting audits and to provide reasons for their decisions. ${ }^{130}$ All FSC decisions are publicly available online and are actively scrutinized by a variety of actors. ${ }^{131}$

\footnotetext{
126 Ibid. at 82. See also Wood, supra note 57 at 193-200.

127 Ibid. at 209-210.

128 Tollefson FSC, supra note 2 at 307. See also: Graeme Auld \& Lars H Gulbrandsen, "Transparency in Nonstate Certification: Consequences for Accountability and Legitimacy" (2010) 10 Global Environmental Politics 97. 129 Meidinger, supra note 109 at 67.

130 Specified in: Stakeholder Consultation for Forest Evaluation - FSC-STD-2O-OO6 (V3-O) (Forest Stewardship Council, 2009)

${ }^{131}$ Most notable is the independent NGO, FSC-Watch online: <http://www.fsc-watch.org/>. Meidinger, supra note 109 at 78 (noting that the competitor certification bodies scrutinize and criticize each other because they are competing for business).
} 
In addition to pointing to these accountability proxies, Meidinger attempts to make sense of the overlapping accountability mechanisms within the FSC. But, ultimately, he argues that existing accountability theories are inadequate for this task. ${ }^{132}$ At times, he even suggests that accountability might boil down to effectiveness. ${ }^{133}$ And he admits that it is unclear how the various accountability mechanisms within the FSC answer to society and further its interests. ${ }^{134}$ Meidinger is not alone in this respect. Skeptics worry that the FSC is only really accountable to its members, a voluntary group already united by its singular mission. ${ }^{135}$ They note there is no independent body, no international judicial review, to which outsiders may appeal when they seek to contest a decision of the FSC. ${ }^{136}$ In short, we are told by governance scholars that accountability is a key evaluative criterion of complex governance regimes, such as FSC, but are left with no firm grip on what this means.

The preoccupations of FSC commentators thus track those in other areas of environmental governance. Debates over "output legitimacy" or effectiveness are always frontand-centre. ${ }^{137}$ Law is "side-lined." It is treated in purely instrumental terms and only discussed when it serves a primary goal of effectiveness, transparency, participation or accountability. In short, the focus on environmental governance does seem to have transformed the underlying

\footnotetext{
${ }^{132}$ He offers three theories: (1) a sum of regulatory components approach, which he critiques as too static to capture the dynamic interactions that take place within forest certification, (2) a normative fidelity approach, which he rejects because it does not account for the abrupt and radical changes in forestry norms (e.g. recognition of indigenous rights that was previously rejected in the field), and (3) a learning approach, which he argues has the most promise but is incomplete: Ibid. at 84-7. We take up this learning approach-democratic experimentalismin the following chapter. I argue that the promise of democratic experimentalism can be realized only once we situate this within an equally democratic understanding of the rule of law.

133 Ibid. at 86.

134. Ibid.

135 Walter "Consumerism", supra note 121 at ; Black, supra note 19 at 141 ("The problem of accountability....reaches its zenith in decentred or polycentric regulatory regimes at any level which are characterized by a strong, but not necessarily exclusive, presence of non-state regulators.")

136 Ibid. at 138.

137 Michael Wilkinson, "Three Conceptions of Law: Towards a Jurisprudence of Democratic Experimentalism" (2010) 2010 Wisc L Rev 673 at 696; “Upside Down”, supra note 34 at 724 (observing a common concern amongst commentators is that new governance approaches will undermine programmatic agendas.
} 
conception of the rule of law. But this transformation has rendered it indistinguishable from a crowded field of metrics for assessing governance.

\section{Part III. Reclaiming the Rule of Law}

Thus far we have seen that there is no clear dichotomy between 'law' and 'governance.' The examples from the British Columbia forestry context show that a mix of policy instruments governs forest practices in the province. Moreover, each example combines aspects of conventional regulation with novel governance features such as public-private relationships in the FRPA, collaborative ecosystem governance in the GBRA, and the non-state, marketbased design of the FSC. I have highlighted the strengths of these examples: how they can attend to the complexity of forestry issues, produce scientifically-based rigorous standards, and foster inclusive and meaningful participation. At the same time, we have seen that all three examples depart significantly from the formal conception of the rule of law and thus raise the underlying concern of arbitrariness.

Skeptics and supporters of these examples have touched on arbitrariness, but largely indirectly through the language of effectiveness, transparency, participation and accountability. These are all important features, to be sure, but as we will now see, none are synonymous with the rule of law. They do not capture what is distinctive about law. That is, they miss the fact that law constitutes a particular relationship between lawmaker and legal subject, a relationship that respects the autonomy of the subject. Indeed, I now argue that by missing this constitutive aspect of law, governance scholars have abandoned the language needed to articulate more

precisely both the strengths and concerns illuminated by the various examples of governance outlined above. 
We have seen that effectiveness is the primary concern of governance scholars. They argue that formal legal constraints can restrict our ability to do what is necessary to respond to complex environmental problems: e.g., collaborate with relevant parties to reach a difficult decision that was not visible a priori, allow for flexible rules that respond to a dynamic problem, or formulate a transnational set of standards that address a complex problem when states are unwilling to adequately respond. For governance scholars, formal law may be valuable, but its value is contingent on an empirical determination about whether formal legal regulation is effective.

Whether any given instance of environmental governance will, in fact, protect the environment is of course a vital consideration. It is also a consideration that is connected to the formal conception's underlying concern with arbitrariness. As we saw in the previous chapter, evidence of environmental degradation may be evidence of arbitrariness; evidence, that is, that decisions ostensibly made in the public's name are in fact serving special interests. But we have also seen that whether a particular instance of governance is effective is frequently contested. ${ }^{138}$ Initial goals might be ambiguous, monitoring and evidence of environmental improvement may be patchy or may lag well behind our efforts. Reclaiming the rule of law in this conversation reveals that the focus on effectiveness as an objective ex post evaluative criterion is too narrow. The rule-of-law concern for arbitrariness safeguards individual autonomy such that we can reason collectively about the best course of action for protecting the environment. This means that we must also examine how environmental decisions are made and what measures are in

\footnotetext{
138 Supra note 121.
} 
place to ensure environmental governance decisions are a product of collective, publicregarding reasoning.

Governance scholars appropriately turn to features of transparency, public participation and accountability, all of which promise to attend to the potential for arbitrariness. But, again, the focus is too narrow. Accountability, for its part, is a vague term, one that has become "a placeholder for multiple contemporary anxieties." ${ }^{399}$ The literature on accountability is vast. Julia Black succinctly describes accountability in these terms: "To be accountable is to agree to subject oneself to relationships of external scrutiny which can have consequences." ${ }^{440}$ The appeal of the language of accountability in the governance literature is that it addresses a breadth of relationships that extends well beyond formal legal accountabilities (such as judicial review, or liability in tort or contract). This focus on accountability, however, raises two problems. For one, the language of accountability suggests that the relationship arises only after the fact, as a mechanism to control the exercise of political power. ${ }^{141}$ The rule of law, on the other hand, is there from the beginning. The rule of law is not only a constraint on power; it is also constitutive of a particular kind of relationship between lawmaker and subject, a relationship that brings about its own kind of authority and legitimacy. ${ }^{142}$

More sophisticated theories of accountability attempt to address the constitutive aspect of accountability relationships, but do not address why any given relationship should be

\footnotetext{
139 Jerry L Mashaw, "Accountability and Institutional Design: Some Thoughts on the Grammar of Governance" Michael Dowdle eds, Public Accountability: Designs, Dilemmas and Experiences (Cambridge: Cambridge Univ Press, 2006) 115 at 117.

${ }^{140}$ Black, supra note 19 at 150 .

${ }^{141}$ David Dyzenhaus, "Accountability and the Concept of (Global) Administrative Law" (2009) 2009 Acta Juridica 3 at 25 [Dyzenhaus] ("Accountability, as it is commonly used, is a term of art developed in a political science literature about ways of exercising controls of the exercise of power. In that idiom law is simply one among many mechanisms that can be used to promote accountability, which is why suing a power holder in court seems the principal means law offers to those subject to power.")

${ }^{142} \mathrm{Ibid}$. at 25-6.
} 
authoritative. For example, Black argues that each accountability relationship "is an interpretive and discursive schema through which participants in the accountability relationship make sense of their own and each other's roles, which is constitutive of their relationship and which is fundamentally shaped by it." ${ }^{143}$ But she does not answer the next obvious question: constitutive of what? Black stresses the fact that each accountability relationship will have its own distinct logic such that one accountability relationship cannot be readily substituted for another. ${ }^{144}$ Thus, when multiple accountability relationships coexist—as they do in any governance institution - the decision-maker will face an accountability dilemma. She argues it must therefore choose which accountability relationships to satisfy and which to ignore. ${ }^{145}$

This focus on multiple and competing accountability mechanisms is characteristic of a theme ever present in the governance literature that " $[\mathrm{t}]$ here is nothing to govern...only problems to confront and decisions to make." ${ }^{146}$ And as McDonald has argued, this is a highly problematic conclusion from the perspective of the rule of law. Such an observation is “inconsistent with a belief that regulation could ever be an authoritative or legitimated response to social problems. Rather, regulation just is: we can understand it, but lose sight of it as an instrument of authoritative governance." 147

By refocusing on the rule of law, the existence of multiple accountabilities within complex networks of governance does not disappear. Rather, it allows us to deepen our

\footnotetext{
${ }^{143}$ Black, supra note 19 at 152.

${ }^{144}$ Ibid.

145 Ibid. at $150-1$.

${ }^{146}$ Freeman, supra note 21 at 548. I've rearranged the quote slightly. The original quote is: "In my conception, however, there are only problems to confront and decisions to make. There is nothing to govern."

${ }^{147}$ Mcdonald, supra note 1 at 202.
} 
understanding of the conditions under which some of these relationships will become authoritative. As we will see in detail in the following chapter, law derives its authority from its compliance with the rule of law, such that without rule of law, there is no rule by law. ${ }^{148}$ This authority arises from the fact that compliance with the rule of law respects the autonomy of those subject to the law, by treating them as rational agents capable of actively participating in their own system of governance.

When governance scholars examine the criteria of transparency and participation, they surely have this idea in mind. Transparency and participation are features that are typically necessary for individuals to be active participants in any system of governance, but they are not ends in themselves. More is not always better. There may be good reasons for a decision-maker to restrict public access to information, for example to encourage regulated parties to be more forthcoming. And scholars of deliberative democracy have puzzled over the inherent trade-off between participation and deliberation: hundreds of participants cannot effectively reason together. ${ }^{149}$ The narrow and disconnected focus on transparency and participation may explain why governance scholars are always fuzzy on the details about what these criteria actually require. ${ }^{150}$ In any given administrative setting, requirements of participation and transparency will need to be addressed contextually. By abandoning the rule of law, governance scholars miss how it promises to guide this contextual analysis.

\footnotetext{
148 Dyzenhaus, supra note 141 at 6-7.

149 We take up deliberative-democratic theory in more detail in the next two chapters.

${ }^{150}$ Black makes this point in Julia Black, "Proceduralizing Regulation: Part I" (2000) 20 Oxford J Legal Stud 597.

She then goes on to argue that democratizing regulation requires more precision in what we mean by

"democracy," which can lead to fairly radical implications for conventional regulation: Julia Black,

"Proceduralizing Regulation: Part II" (2001) 21 Oxford J Legal Stud 33.
} 
In short, Pardy and Walter are onto something when, to paraphrase, they suggest that environmental governance presents an inherent risk of arbitrariness that demands a structural, institutional and normative analysis. And Meidinger is onto something when he suggests that we might consider the FSC a form of administrative law. ${ }^{151}$ But they have not taken up the challenge of showing that a democratic conception of the rule of law can govern even when our institutional arrangements take seriously the environmental emergency. This is the task of the next two chapters.

\section{Conclusion}

This chapter has argued that the framework of the environmental emergency allows us to expose the assumptions about environmental issues and law contained in the burgeoning literature on environmental governance. I have argued that instances of environmental governance can respond to the complexity of environmental issues through flexible planning requirements, collaborative or networked governance, or non-state certification processes. This requires, however, that environmental governance depart in significant ways from the formal conception of the rule of law. Because environmental governance scholars-supporters and critics alike - generally assume a formal conception of the rule of law, they dismiss the rule of law as irrelevant. Instead, as we have seen, they evaluate environmental governance on a set of alternative criteria. I argued that, by jettisoning the rule of law, environmental governance scholars lack the language to precisely articulate the strengths and weaknesses of novel forms of governance. By reclaiming the rule of law, and its underlying concern of arbitrariness, we are able to make sense of the disconnected criteria presented in the existing literature.

\footnotetext{
${ }^{151}$ On the emerging area of global administrative law see: Stewart et al, supra note 118 . For a critique of how global administrative law avoids the hard question of what makes it law see: Dyzenhaus, supra note 141.
} 
Chapters 3 and 4 have argued that understanding environmental issues as an ongoing emergency provides a framework for thinking through assumptions about the promise and limits of law that are implicit in existing approaches to Canadian environmental law. We have now seen that environmental reformers and environmental governance scholars both tend to assume a formal conception of the rule of law. This leads environmental reformers to ignore the emergency nature of environmental issues and advocate for a rule-of-law façade that provides no meaningful legal constraint. It leads scholars of environmental governance to dismiss the rule of law as essentially irrelevant. As I have hinted throughout this chapter, however, we are not limited to the formal conception of the rule of law. The second half of this thesis develops an alternative theory of the rule of law, one that responds to Schmitt's challenge and can be maintained even under conditions of the environmental emergency. 


\section{Responding to the Environmental Emergency}

\section{Introduction}

Having argued that the existing responses to the environmental emergency fail Schmitt's challenge, we will now return to legal theory on national security emergencies to develop a rule-of-law response to the environmental emergency. The objective of this chapter is to set out a democratic conception of the rule of law that can both constitute and constrain the exercise of public authority over the environment. It does this by drawing out the connections between common law constitutionalism and deliberative democracy. We will see that common law constitutionalism requires public decision-makers to publicly justify their decisions on the basis of deeply-rooted common law principles. One particular strand of deliberative-democratic theory, democratic experimentalism, looks to creative institutional design in order to realign democratic values with effective public problem-solving. I argue that common law constitutionalism refocuses our attention on foundational rule-of-law principles, and democratic experimentalism offers the kind of institutional innovation necessary to maintain these principles in complex regulatory contexts. At base, these two schools of thought share an understanding of the individual as a responsible agent capable of engaging in the ongoing project of democratic governance under the rule of law. Public officials respect the individual's rational and self-determining capacity through the requirement of reason-giving. We will see

that, under the conditions of the environmental emergency, reason-giving gives rise to a further requirement to experiment with institutional design in order to ensure that defensible 
reasons can be produced, contested and publicly reviewed to ensure their compliance with a democratic conception of the rule of law.

This theory draws heavily on the work of Lon Fuller and his insight that what makes law law is its compliance with the requirements of the rule of law. On this view, the rule of law gives rise to a reciprocal relationship between legal subject and state. Law is not, as Fuller put it, "a one-way projection of authority" ${ }^{1}$ from lawmaker to legal subject, a command which the subject must obey or risk sanction. Rather, by complying with the rule of law, public officials respect the capacity of individuals as rational and autonomous agents. This compliance is what gives law its authority; it creates a reciprocal obligation on the part of the individual to obey the law. ${ }^{2}$ We will see that David Dyzenhaus argues that Fuller's insight about the rule of law is best expressed as a requirement of public justification, which requires that public decisionmakers offer reasons for their decisions that reflect core common law principles, such as fairness and reasonableness. The challenge, then, is showing how decisions made in response to complex and constantly evolving environmental issues can meet this requirement of public justification.

Importantly, this understanding of law also implies a second reciprocal relationship, one between democracy and law. From this perspective, the rule of law is a vital part of ongoing public deliberation about core constitutional commitments. Through the process of translating public deliberations into law, these deliberations are made subject to the requirement of public

\footnotetext{
${ }^{1}$ Lon L Fuller, The Morality of Law Rev ed, (New Haven, CT: Yale University Press, 1969) at 207 [Fuller].

${ }^{2}$ Ibid. at 39, 219-220. Fuller's claim that compliance with the rule of law includes a reciprocal obligation of obedience is controversial. For a summary of the complex debates on the duty to obey the law see: William A Edmundson, "State of the Art: The Duty of Obey the Law" (2004) 10 Legal Theory 215. For present purposes, it is sufficient to accept a weaker version of Fuller's claim that, in modern liberal societies, respect for individual agency requires general compliance with the rule of law.
} 
justification. This requires institutions that allow legal subjects to contest public decisions and demand that they meet this requirement of public justification. This practice of public justification and contestation means that the rule of law itself is central to public deliberation. ${ }^{3}$ Every exercise of legal authority has the potential to prompt further deliberation about what our core constitutional values are and how we should achieve them. Dyzenhaus calls this the "rule-of-law project," ${ }^{4}$ a phrase that nicely captures the idea that a democratic society governed by the rule of law is always a work in progress that requires the ongoing commitment of its participants - both public officials and the public alike.

Understanding the rule of law as a project also has an important methodological implication. Rather than reasoning from abstract principles, for purposes of theorizing we should look for real-life examples of cases or institutions that reflect rule-of-law ideals. Constitutional principles do not stand independently of the practices through which they are realized; through the requirement of public justification they are continually rearticulated and redefined. We should thus look for concrete examples which can help draw out theoretical insights about the rule of law, and which can be used as a platform for further interpretation and experimentation. To this end, this chapter begins with examples from Canadian administrative and environmental law, not because they are ideal models nor to set out a decisive blueprint for reform, but because they show how creative institutional design can give rise to the conditions for public justification. In particular, we will see that the British Columbia Forest Practices Board factors prominently in this chapter as an example of an existing institution that approximates in important but unconventional ways the rule-of-law

\footnotetext{
${ }^{3}$ Elaborated on in Part III infra.

${ }^{4}$ David Dyzenhaus, The Constitution of Law: Legality in a Time of Emergency (Cambridge: Cambridge University Press, 2006) at 17 [Dyzenhaus Constitution].
} 
requirement of public justification. The theory, therefore, comes at the end of the chapter, after we have examined existing practices of courts, tribunals and the Forest Practices Board which offer insight into how public justification can be realized in environmental law.

One caveat on the analysis that follows is that what I mean by 'core constitutional principles' will remain intentionally open-textured and undefined throughout this chapter. This is the focus of Chapter 6, where we examine in detail the content of public justification: i.e., the decision-making procedures and reasons for an environmental decision that will be defensible from this perspective on the rule of law. For present purposes, these requirements mirror the basic (though much debated) principles of procedural fairness and reasonableness. The focus of this chapter is on the intersection between the rule of law and institutional design and how together these strands of the analysis can allow public justification to occur, even in complex regulatory contexts.

This chapter proceeds in three parts. The first part seeks to answer Schmitt's challenge. This kernel of the answer is provided by David Dyzenhaus, who argues that an alternative to the formal conception of the rule of law has emerged, albeit imperfectly, from the Supreme Court of Canada's messy administrative law jurisprudence. This alternative is a common law constitutional conception that can be traced to Dicey's understanding of the rule of law and how it operates in times of crisis. What follows from this analysis is the conclusion that the court is not always in a position to ensure that an emergency decision is justified; thus creative institutional design is necessary. I then extend this line of argument to the environmental context and argue that environmental appeals tribunals and more creative hybrid institutions 
have the potential to maintain public justification where we otherwise saw legal black and grey holes in Chapter 3.

The existing theoretical work on conventional emergencies does not, however, directly respond to the examples of environmental governance that were the subject of Chapter 4 . The second part therefore turns to theories of deliberative democracy and in particular the governance-focused strand of democratic experimentalism. I argue that democratic experimentalism allows us to think through the possibilities for creative institutional design for maintaining the rule of law even in these complex regulatory regimes. Democratic experimentalism requires ongoing monitoring and analysis of existing regulatory approaches to provide a basis for rigorous public deliberation over how to continually improve our responses to complex and continually changing problems. We will see that the Forest Practices Board has already recommended many democratic experimentalist requirements, and taking up these requirements would allow the Forest and Range Practices Act to comply with the requirement of public justification.

In the third part, I distill the theory from these examples. I develop an account of the rule of law as a project. The rule-of-law project requires an ongoing commitment by all public officials to publicly justifying their decisions, and to institutional innovation when needed to help realize and recommit to this project. We will see that this account emerges from important intersections between common law constitutionalism and deliberative democracy. Both respect and facilitate the rational and self-determining capacity of individuals and their ability to actively participate as equals in their systems of governance. 


\section{Part I. The Rule of Law as Public Justification}

In Chapter 2, I introduced the formal conception of the rule of law as a basic Diceyan conception, which, as we saw, made no provision for exceptional emergency powers. We saw that Dicey's understanding of the constitution gives rise to a formal conception of the rule of law. Dicey sets out two constitutional principles: Parliamentary supremacy and the supremacy of the rule of law. ${ }^{5}$ While Dicey sees these two supremacies working in concert, he is clear that if there is a conflict between the two, Parliament will win. ${ }^{6}$ Dicey also rejected the existence of martial law and the administrative state. From these basic premises, it is only a small step to conclude that, on his view, the legislature is the only legitimate source of legal norms. ${ }^{7}$ We can

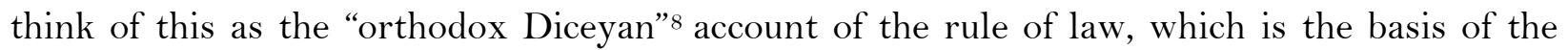
formal conception that has persisted in Canadian administrative law. This is the position, as we have seen, that has led to the creation of legal black and grey holes in Canadian environmental law.

Following on the methodology that I set out in the introduction of the chapter, this part begins with an analysis of Canadian administrative law doctrine to show that an alternative account of the rule of law has emerged in Supreme Court jurisprudence. I argue that the Court has departed from a formal conception of the rule of law and has articulated, albeit inconsistently and imperfectly, a requirement that public officials publicly justify their decisions on the basis of core rule-of-law principles. We will then see that this alternative conception

\footnotetext{
${ }^{5}$ AV Dicey, An Introduction to the Study of the Law of the Constitution 10th ed, (Toronto: MacMillan Company of Canada Ltd, 1959) at 407 [Dicey].

${ }^{6}$ Ibid. at 39-40; TRS Allan, Constitutional Justice: A Liberal Theory of the Rule of Law (Oxford: Claredon Press, 2001) at 13 [Allan].

7 Dyzenhaus Constitution, supra note 4 at 71.

${ }^{8}$ Mark D Walters, "Dicey on Writing the Law of the Constitution" (2012) 32 Oxford J Legal Stud 21 at 22 [Walters]; Allan, supra note 6 at 13. Compare the orthodox interpretation with the substantive interpretation of Dicey offered by Walters, Allan, and that of Dyzenhaus that follows later in this Part.
} 
responds to Schmitt's challenge, set out in Chapter 2, because it can be sustained during emergencies, including the environmental emergency.

\section{A. Public Justification in Canadian Administrative Law}

Notwithstanding the pervasive legal black and grey holes in Canadian environmental law, the Supreme Court of Canada has made significant strides away from a formal conception of the rule of law. The break from the formal conception is usually marked by the watershed Supreme Court decisions in $C U P E^{9}$ and Nicholson ${ }^{10}$ in 1979, and it continues to this day as the judiciary seeks to reconceive its own role in relation to a legitimate administrative state. Together, CUPE and Nicholson signal the Court's recognition that administrative decisionmakers "can make rational decisions about the law" and therefore "judges must not assume that the courts should have the last word about what the law is." ${ }^{11}$ But they also tell judges that they should intervene when administrative decision-makers "fail to live up to the standards which in principle make their decisions rational." ${ }^{12}$ Nicholson extends the requirements of procedural fairness beyond judicial or quasi-judicial administrative decisions. However, this requires judges to acknowledge that rational procedures are not exclusively ones that look like judicial procedures, but are rather procedures that are appropriate to their administrative context. ${ }^{13}$

\footnotetext{
${ }^{9}$ CUPE v NB Liquor Corporation, [1979] 2 SCR 227, 97 DLR (3d) 417.

${ }_{10}$ Nicholson v Haldimand-Norfolk Regional Police Commissioners, [1979] 1 SCR 311, 88 DLR (3d) 671.

${ }^{11}$ Dyzenhaus Constitution, supra note 4 at 127.

${ }^{12}$ Ibid.

${ }^{13}$ Ibid.
} 
The theory behind the two decisions finally merged in the Supreme Court's decision in Baker ${ }^{14}$ where the majority endorsed an understanding of deference as respect. In Baker, the issue concerned the Minister's refusal to exempt from deportation a woman who had illegally overstayed in Canada. The legislation and regulations delegated seemingly unfettered discretion to the Minister to grant an exemption "if satisfied" that relief should be granted on humanitarian and compassionate grounds. For the Court, however, this language did not mean that the Minister operated in a legal grey hole. Rather, the Court found, the Minister's "discretion must be exercised with the boundaries imposed in the statute, the principles of the rule of law, the principles of administrative law, the fundamental values of Canadian society, and the principles of the Charter." 15

To determine whether discretion was publicly justified, the Court had to impose a requirement to give reasons ${ }^{16}$ in order to meaningfully assess whether the decision was reasonable in the sense of reflecting these fundamental legal principles. Under this understanding of the rule of law, decision-makers are not owed deference simply because of their institutional expertise or because they complied with the formal requirements of their enabling statute. Rather, they are owed deference when their decisions are justified. In other words, deference "requires not submission but a respectful attention to the reasons offered or which could be offered in support of a decision." 17 On this view, administrative discretion is not an illegitimate space uncontrolled by law, but is rather legitimate and worthy of judicial respect

\footnotetext{
${ }^{14}$ Baker v. Canada (Minister of Citizenship and Immigration), [1999] 2 SCR 817, 1 Imm LR (3d) 1 [Baker] (pinpoints to SCR).

${ }_{15}$ Ibid. at para 56.

${ }^{16} \mathrm{Ibid}$. at para 43.

${ }^{17}$ Ibid. at para 60, quoting David Dyzenhaus, “The Politics of Deference: Judicial Review and Democracy”, in M Taggart ed., The Province of Administrative Law(1997) 279 at 286.
} 
when exercised in a manner that reflects the fundamental legal principles such as those set out in Baker.

The Court's reasons in Baker reflect a requirement of public justification. Core common law principles form the constitutional backdrop of administrative decision-making and decisionmakers are obligated to show that their decisions reflect these principles. Reason-giving is essential to this conception of the rule of law, because it is by offering public reasons that decision-makers discharge their duty of justification. ${ }^{18}$ Reasons ensure that the individual knows that she or he has not been treated arbitrarily by the state, but they also ensure that the institutions of government can hold one another to account when they fall short in their commitment to the rule of law. Judicial review is one way to ensure that administrative decision-makers meet their requirement of public justification. But it also requires that judges defer — that is, not substitute their own views - when the decision is justified on the basis of core constitutional principles. ${ }^{19}$

Deference as respect and the coexisting duty to give reasons is a sharp contrast to the formal conception, which, as we saw in Chapters 3 and 4, requires the court to defend its monopoly over statutory interpretation and abstain from interfering with the exercise of administrative discretion. Deferring to a Minister's interpretation of a statute, even if it is a reasoned interpretation, would be tantamount to judicial abdication for a formalist judge. Similarly, it would be challenging for a formalist judge to assume a supervisory role over the exercise of Ministerial discretion, as in Baker. A common law constitutional understanding of the rule of law as public justification blurs these lines. It requires the assumption that all public

\footnotetext{
${ }^{18}$ Dyzenhaus Constitution, supra note 4 at 139.
}

19 Ibid. at 147 . 
institutions are engaged in a collective rule-of-law project of ensuring that public decisions are made on the basis of core constitutional values.

The Supreme Court's commitment to the requirement of public justification has admittedly been imperfect. ${ }^{20}$ As we have seen in the environmental context, the formal conception still emerges. Even in the immigration context, the court has retreated from the majority's decision in Baker. In both Suresh, ${ }^{21}$ a post-9/11 national security decision, and later Khosa, ${ }^{22}$ the Supreme Court stated that the court's role was only to ensure that the Minister considered the correct factors, and that "the courts should not reweigh them." ${ }^{23}$ In other words, the Court retreated to a formal understanding of its role. So long as the Minister ticked the appropriate boxes and formally met the explicit statutory criteria, the Court would refuse to evaluate the Minister's exercise of discretion. ${ }^{24}$ The Minister had free rein over how to account for these factors. Moreover, there was no hint in either decision of the non-statutory, common law constitutional principles identified by the majority in Baker. ${ }^{25}$

The Court's important decision in Dunsmuir, ${ }^{26}$ an attempt to set straight the principles of administrative law, itself reflected conflicting conceptions of the rule of law. ${ }^{27}$ The majority reasserted its monopoly over some formal categories of decisions - constitutional questions ${ }^{28}$

\footnotetext{
${ }^{20}$ Evan Fox-Decent, Sovereignty's Promise: The State as Fiduciary (Oxford, New York: Oxford University Press, 2011 ) at 29 (arguing that this is because common law constitutionalism lacks a legal basis for the 'free floating' principle of fairness) [Fox-Decent].

${ }_{21}$ Suresh v Canada (Minister of Citizenship and Immigration), 2002 SCC 1, [2002] 1 SCR 3 [Suresh].

${ }^{22}$ Canada (Minister of Citizenship E Immigration) v Khosa, 2009 SCC 12, [2009] SCR 339 [Khosa].

${ }_{23}$ Suresh, supra note 21 at para 41; Khosa, supra note 23 at para 61.

${ }^{24}$ Fox-Decent, supra note 20 at 228-9 internal endnotes.

${ }^{25} \mathrm{Ibid}$.

${ }^{26}$ Dunsmuir v New Brunswick (Board of Management), 2008 SCC 9, [2008] 1 SCR 190 [Dunsmuir].

${ }_{27}$ Matthew Lewans, "Deference and Reasonableness Since Dunsmuir" (2012) 38 Queen's L J 59 at 74.

${ }_{28}$ Dunsmuir, supra note 26 at para 58.
} 
and true questions of vires, ${ }^{29}$ for example. But it still urged courts to take a contextual approach to determining the appropriate standard of review, ${ }^{30}$ and reiterated that, in cases where deference was owed, the court's role was to ensure "the existence of justification, transparency and intelligibility within the decision-making process." ${ }^{11}$ The majority recommitted itself to the notion of deference as respect. ${ }^{32}$ Since Dunsmuir and the subsequent decision in Khosa, the Supreme Court's formalistic inclinations have again, in some respects, waned. The Court has deferred to administrative decision-makers on issues that fell squarely within traditional judicial strongholds, including constitutional questions, ${ }^{33}$ the application of the common law doctrine of estoppel, ${ }^{34}$ and the breach of a statutory deadline, which would have conventionally been labelled a true question of vires. ${ }^{35}$ Indeed, the Court has suggested that the concept of a true question of vires, the very basis on which a formalist judge justifies judicial review, may have been a fiction after all, ${ }^{36}$ signaling the rejection of the formal conception.

Moreover, the Court has since restated its position in Baker, that there is no such thing as unfettered discretion. ${ }^{37}$ It is noteworthy that this clear statement occurred with respect to a municipal by-law — delegated legislation issued by a democratically elected decision-maker. A unanimous Supreme Court found that this decision was subject to the supervision of the courts because " $[\mathrm{t}]$ he fact that wide deference is owed to municipal councils does not mean they have

\footnotetext{
$29 \mathrm{Ibid}$. at para 59.

30 Ibid. at para 64.

${ }^{31}$ Ibid. at para 47.

32 Ibid. at para 48 .

${ }^{33}$ Doré v. Barreau du Québec, 2012 SCC 12, [2012] 1 SCR 395. See, more recently, Loyola High School v. Quebec (Attorney General), 2015 SCC 12.

34 Nor-Man Regional Health Authority v Manitoba Association of Health Care Professionals, 2011 SCC 59, [2011] 3 SCR 616.

${ }_{35}$ Alberta (Information and Privacy Commissioner) v. Alberta Teachers' Association, 2011 SCC 61, [2011] 3 SCR 654 [Teachers'] (pinpoints to SCC). See also Halifax (Regional Municipality) v. Nova Scotia (Human Rights Commission), 2012 SCC 10, [2012] 1 SCR 364 (where the SCC again distanced itself from the concept of a jurisdictional question)

${ }^{36}$ Teachers', supra note 35 at para 34.

${ }_{37}$ Catalyst Paper Corp. v. North Cowichan (District), 2012 SCC 2, [2012] 1 SCR 5 [Catalyst] (pinpoints to SCC).
} 
carte blanche." 38 Indeed, the Court observed that the "attempt to maintain a clear line between policy and legality has not prevailed." 39 The Court reasserted its supervisory role to ensure that, in passing delegated legislation, a municipality adheres to both procedural and substantive requirements of legality.40 The Court held that, while a municipal council is not required to give reasons when exercising its legislative function, its reasons could be found in "the debate, deliberations and the statements of policy that give rise to the bylaw." 41

In other words, the Supreme Court has recognized, albeit only in limited circumstances, that the requirement of public justification requires courts to supervise highly discretionary, policy-laden executive action that falls well outside their traditional monopoly: i.e., the very features of environmental decisions that often cause judges to retreat to the formal conception. The very fact that the legislature has governed by law - delegating authority to the municipality - gives rise to the rule of law, understood as the requirement of public justification.

\section{B. Public Justification During Emergencies}

Interestingly, Dyzenhaus argues that this concept of public justification can be traced to Dicey's account of emergency powers. Dyzenhaus argues that Dicey's unwillingness to address discretionary executive powers precludes Dicey from seeing that his very own account contains the kernels of a rule-of-law response to the administrative state.

\footnotetext{
${ }_{38}$ Ibid. at para 24.

39 Ibid. para 14.

40 Ibid. at para. 16. Remarkably, the Court seems to impose a requirement of procedural fairness without addressing the category of 'legislative functions.'

${ }^{41} \mathrm{Ibid}$. at para 29. See also David J Mullan, "Judicial Review of Executive Decision-making: Evolving Concepts of Responsibility" (1993) 19 Queen's L J 137 (suggesting that the assumption of courts, that the executive was worthy of respect and tribunals were viewed with suspicion might be backwards).
} 
Dicey addresses the use of Habeas Corpus Suspension Acts in times of crisis, statutes which deny those charged with a crime the right to compel a trial or their release. ${ }^{42}$ At first glance, a Suspension Act might appear to be a classic example of a legal black hole because it suspends constitutional rights during emergencies. But Dicey argues that it does not suspend rights, rather it defers access to certain remedies so long as the Act is in force. ${ }^{43}$ Dicey bases this argument on the fact that an Act of Indemnity will almost always follow a Suspension Act, which demonstrates that, but for the Act of Indemnity, officials would be found guilty of unlawful acts taken while the Suspension Act was in place. ${ }^{44}$

What is key to Dicey's account is that the two Acts do not come together and therefore do not legalize executive action in advance. An Act of Indemnity is still a legislative act and is therefore, according to Dicey, "very different from the proclamation of martial law." 45 The fact that it is a legislative act means that actions taken purportedly under the Act of Indemnity will be subject to review by the courts. ${ }^{46}$ Although the effect of the Act is to immunize public officials for their emergency response actions, whether any specific action is covered by the legislation can be challenged in the courts. Even a wide the delegation of power by Parliament, such as an Act of Indemnity, is subject to the interpretation by judges who are influenced, Dicey states, "by the general spirit of the common law." 47 Judges will, in other words, interpret the Act of Indemnity against the backdrop of the common law to ensure that indemnified acts

\footnotetext{
${ }^{42}$ Dicey, supra note 5 at 229.

43 Ibid. at 230 .

44 Ibid. at 232 .

$45 \mathrm{Ibid}$. at 237.

${ }^{46}$ Ibid. at 413. Recall that a black hole says in advance that whatever the executive does is legal: Dyzenhaus Constitution, supra note 4 at 202.

${ }^{47}$ Dicey, supra note 5 at 413.
} 
were taken in good faith and were not recklessly cruel. ${ }^{48}$ Put differently, the discussion of the Suspension Act and Act of Indemnity is not simply about the timing of the two. Rather, it “opens up the conceptual space for prospective legislative responses to states of emergency which give officials authority to act $\ldots$ but which require that ... they justify to an independent tribunal their decisions as both necessary and made in good faith.” 49

For Dyzenhaus, then, Dicey's constitutionalism demonstrates that rule by law implies rule of law because the implementation of legislation is put under the supervision of the courts, whose job it is to maintain the rule of law. Even during an emergency, public officials are subject to a requirement of public justification. That is, they must justify the actions taken under the Suspension Act before the "ordinary court," which is guided by the "general spirit of the common law" in order to benefit from the protection of the Act of Indemnity. ${ }^{50}$ Dyzenhaus argues that Dicey's account contains three essential features: review before an independent body (for Dicey this would have been the court), that the body has access to the information upon which the executive bases its justification, and that the state bears the burden of showing that the decision was justified. ${ }^{51}$

Dyzenhaus argues that Dicey's account opens up the possibility of creative institutional design. Creative design is necessary because, as Dyzenhaus charts, judges have a disappointing history of losing their "rule-of-law nerve" in times of crisis, meaning that they seem unable to

\footnotetext{
48 Dyzenhaus Constitution, supra note 4 at 203. Of course, this depends on the specific language of the statute. Were a statute to specify that it covered even recklessly cruel acts and acts otherwise taken in bad faith, then we would have a legal black hole.

49 Dyzenhaus Constitution, supra note 4 at 204.

${ }^{50}$ Dicey summarizes this argument in Dicey, supra note 5 at 412-414. See also Walters, supra note 8 at 35 ("Dicey's three propositions on the rule of law are, as strict rules, descriptively false and normatively problematic, but as general principles they may be, even today, both factually true and morally compelling.")

${ }_{51}$ Dyzenhaus Constitution, supra note 4 at 204-5.
} 
uphold this requirement of public justification. ${ }^{52}$ Moreover, the executive often has legitimate claims to national security privilege, and national security issues raise complex and politically sensitive issues that the court does not necessarily have the expertise to assess. ${ }^{53}$

From the perspective of the public-justification conception of the rule of law, the separation of powers, like any institutional design, is only useful to the extent that it enables the realization of foundational constitutional principles. ${ }^{54}$ This, Dyzenhaus argues, allows the requirement of justification to be fulfilled even in times of crisis where robust judicial scrutiny is not possible. ${ }^{55}$ For example, Dyzenhaus points to a special immigration appeals tribunal in the United Kingdom in charge of reviewing deportation decisions, that, but for sensitive information pertaining to national security, would be reviewed by the court. ${ }^{56}$ The tribunal has expertise in national security, immigration, and law, and has special powers to allow government claims of secrecy to be tested in closed proceedings. ${ }^{57}$ The procedures are far from perfect, ${ }^{58}$ but, on their face, they reflect a commitment to public justification. The tribunal ensures that the executive's deportation decision is justified, and in turn the court ensures that the tribunal's decision is justified. ${ }^{59}$ The court must also justify its decision on the basis of

\footnotetext{
${ }^{52}$ E.g. Suresh, supra note 21 and Khosa, supra note 22; Dyzenhaus Constitution, supra note 4 discusses prominent UK wartime decisions. See also Jeffrey Jowell, "The Democratic Necessity of Administrative Justice" (2006) Acta Juridica 13 at 21 ("Above all, courts should be willing to challenge bare assertions.").

${ }_{53}$ Dyzenhaus Constitution, supra note 4 at 219.

${ }^{54}$ David Dyzenhaus, "Constituting the Rule of Law: Fundamental Values in Administrative Law" (2002) 27 Queen's LJ 445 at 451 ["Fundamental Values"].

${ }_{55}$ Dyzenhaus Constitution, supra note 4 at 174-90.

${ }_{56}$ Special Immigration Appeals Commission Act 1997, 1997 c 68 (UK).

57 Dyzenhaus Constitution, supra note 4 at 163.

${ }_{58}$ Secretary of State for the Home Department v MB [2007] QB 415 (Sullivan J., overturned by the Court of Appeal, described the special advocates procedure as creating a "thin veneer of legality".) Numerous lawyers acting as special advocates, representing the claimant's interests in the closed proceedings, have quit because of the inadequacy of the process: Clare Dyer, "Terror QC: More Will Quit Special Court" The Guardian (20 December 2004), online: The Guardian <http://www.theguardian.com/politics/2004/dec/20/terrorism.humanrights>.

${ }_{59}$ Dyzenhaus Constitution, supra note 4 at 178 . Though Dyzenhaus makes clear that his is an aspirational account, since the role of judicial review that he describes is one that judges tend to struggle with.
} 
fundamental common law principles. ${ }^{60}$ Thus, judicial review need not be conceived of as an allor-nothing endeavour where judges are torn between blindly deferring to the executive or second-guessing and intruding on national security decisions. Rather, it can be understood as a more nuanced role where the court ensures that other institutions of government are maintaining their commitment to the rule of law, ${ }^{61}$ understood as a requirement to publicly justify decisions on the basis of core constitutional principles.

Dyzenhaus' articulation of common law constitutionalism offers a full response to Schmitt's challenge set out in Chapter 2. Dyzenhaus does not admit the exception. Discretionary emergency powers are subject to the requirement of public justification. Even the decision to abandon ordinary constitutional requirements to respond to an emergency is subject to the requirement of public justification. Dyzenhaus concedes that there is no way to prevent a determined Parliament from creating a legal black hole through unequivocal, express language. But the answer to Schmitt's challenge in such a case is that the failure to abide by the rule of law calls into question the claim to legal authority: i.e., the legal black hole may be formally valid, but it will have a dubious claim to authority. ${ }^{62}$ The court's role in this instance is to act as the weatherman "alerting the commonwealth to the storm clouds on the horizon when the rule of law which secures the fabric of civil society is put under strain."63

\footnotetext{
60 "Fundamental Values", supra note 54 at 501-2.

${ }^{61}$ Lorne Sossin, "The Unfinished Project of Roncarelli v. Duplessis: Justiciability, Discretion, and the Limits of the Rule of Law" (2010) 55 McGill LJ 661 at 687.

62 Dyzenhaus Constitution, supra note 4 at 204.

${ }^{63}$ Ibid. at 12 .
} 


\section{Implications for the Environmental Emergency}

We saw in Chapter 3 that environmental reformers are deeply distrustful of administrative discretion. Thus, the public-justification argument that courts owe administrative decision-makers respectful deference would strike many environmental reformers as counterintuitive. However, as we have now seen, deference as respect implies that deference must be earned. It is earned when decisions reflect core common law principles. In short, the public-justification conception means that discretion is not a legal black or grey hole; rather it is a space that is governed by common law principles and, indeed, must be governed by these principles to have any authority as law at all. Moreover, we have seen, maintaining public justification in the national emergency context requires creative institutional design because the courts are not always equipped to supervise the exercise of emergency powers. In other words, emergencies reveal an institutional gap. They reveal the need for a carefully designed institution that can review executive decisions even under the challenging conditions of the emergency. We will now see that this insight has significant implications for responding to the ongoing environmental emergency.

\section{i. Tribunals}

Environmental appeals tribunals - analogous to the special immigration appeals tribunal discussed by Dyzenhaus - are ubiquitous across Canada. ${ }^{64}$ Board members have specialized expertise for reviewing a variety of environmental decisions such as pollution

\footnotetext{
${ }^{64}$ See, for example, Jerry V DeMarco and Paul R Valdoon, Environmental Boards and Tribunals in Canada: $A$ Practical Guide (Markham, Ont: LexisNexis, 2011) [DeMarco \& Valdoon]; Mark Haddock, Environmental Tribunals in British Columbia (Victoria: Environmental Law Centre, University of Victoria, 2011) [Haddock].
} 
permits and approvals, cleanup orders, and penalties. ${ }^{65}$ The mandates, procedures and functions of Canadian environmental appeals tribunals are diverse. Thus, the extent to which any given tribunal is capable of fulfilling the requirement of justification depends on its specific context. ${ }^{66}$ Moreover, a wide range of environmental decisions — indeed, entire statutes — fall outside the scope of existing environmental tribunals, ${ }^{67}$ suggesting that there is much work to be done to ensure that the requirement of public justification can be fulfilled in the environmental context.

There is little independent academic attention given to environmental tribunals, which suggests their rule-of-law potential may be overlooked. ${ }^{68}$ Environmental tribunals originated, by and large, in response to industry concerns about fairness. Concerned about strict requirements of licenses and approvals ${ }^{69}$ and enforcement practices, ${ }^{70}$ environmental appeals tribunals provided a quasi-judicial solution that combined technical expertise and efficiency with demands for fairness and accountability. As such, applicants for licenses and those subject to administrative orders have the right to appeal unfavourable decisions to the appropriate environmental tribunal. ${ }^{71}$ Typically, these tribunals are also empowered to hear claims $d e$ novo. ${ }^{72}$ This can add to the perception that they are technical institutions rather than

\footnotetext{
${ }_{65}$ DeMarco \& Valdoon, supra note 64 at 15-18. Marilyn G Lee, "How Tribunals and Appeal Boards are Contributing to Advances in Environmental Laws" (2014) 26 JELP 249 at 262-4 [Lee] (on how merit-based appointments has improved the quality of decision-making at environmental appeals tribunals).

${ }^{66}$ Common generic criticisms include: limited standing for parties that are not the regulated party, licensing decisions are only appealable at time of initial issue, not when licenses are amended or renewed (Haddock, supra note 64 at 26-7). See also Cindy Chiasson, "Public Access to Environmental Appeals: A Review and Assessment of Alberta's Environmental Appeals Board" (2007) 17 JELP 141 (reporting on the significant limitations to public participation at the Alberta Environmental Appeals Board).

${ }^{67}$ Haddock, supra note 64 at 23.

${ }^{68}$ Lee, supra note 65 at 251 (noting the dearth of attention, and seeking to correct that). Nigel Bankes, "Shining a Light on the Management of Water Resources: The Role of an Environmental Appeal Board" (2006) 16 JELP 131 at 132 [Bankes] (noting that the jurisprudence of environmental appeals boards is worthy of study in its own right).

${ }^{69} \mathrm{Ibid}$. at 136.

${ }^{70}$ William A Tilleman, "Environmental Appeal Boards: A Comparative Look at the United States, Canada and England" (1996) 21 Colum J Envt'l L 1 at 7.

${ }^{71}$ Jamie Benidickson, Environmental Law (Toronto: Irwin Law, 2009) at 134.

${ }^{72}$ De Marco \& Valdoon, supra note 64 at 11.
} 
contributors to the rule-of-law project, as they are effectively required to remake policy decisions.

Yet many tribunals also have a public interest mandate with some allowance for public interest standing. This gives rise to the possibility of ensuring that decisions with environmental consequences are publicly justified. ${ }^{73}$ Indeed, there is much potential for these tribunals to become genuine participants in ensuring public justification. Nigel Bankes has argued that environmental tribunals "articulate reasons for a decision that connect the particular application with the more general context - a task which may not be perceived as part of the responsibilities of the original decision-maker." ${ }^{74}$ Moreover, recent preliminary evidence suggests that, in setting out these reasons, tribunals are more willing to invoke emerging environmental principles, such as precaution, than courts. ${ }^{75}$ Even where tribunals are not independent - for example in the case of the Alberta Environmental Appeals Board which makes recommendations to the Minister - there are tentative steps to recognizing an obligation on the part of the Minister to offer reasons for rejecting the tribunal's recommendation. ${ }^{76}$ This suggests that, even where tribunals have limited mandates, they can still be understood as part of the commitment to the rule-of-law project and not just an additional formal or technical layer in the decision-making process.

\footnotetext{
${ }^{73}$ Whether this occurs is another matter as there is much variation. The Alberta Environmental Appeals Tribunal, for example, can only hear claims brought by those who are "directly affected": Environmental Protection and Enhancement Act, RSA 2000, c E-12 s $91[A E P E A]$. And the tribunal and Alberta Courts, on review, have interpreted this narrowly: Kostuch v. Alberta (Director, Air \& Water Approvals Divisions, Environmental Protection), 1996 CanLII 10565 (AB QB), 35 Admin LR (2d) 160 [Kostuch]. In contrast the Ontario Bill of Rights allows any member of the public to initiate an appeal where there is a prima facie case the decision was unreasonable and that environmental harm could result: Environmental Bill of Rights, 1993, SO 1993, c 28 ss38 and 41. The requirement to be "directly affected" is taken up in Chapter 5 .

${ }^{74}$ Bankes, supra note 68 at 138 .

${ }^{75}$ Lee, supra note 65 at $264-5$.

${ }^{76}$ Bankes, supra note 68 at 181-2; AEPEA, supra 73 note at s 100. Note also the executive override provisions in British Columbia and Ontario: Environmental Management Act, SBC 2003, c 53 s 97 and Environmental Protection Act, RSO 1990, c E.19 s 145.6.
} 
Many environmental tribunals lack a statutory right of appeal to the courts, thus the only avenue for review is by way of judicial review. ${ }^{77}$ Existing judicial decisions offer some mixed evidence about whether they view tribunals as participants in the rule-of-law project. As a general rule, courts require that parties exhaust internal administrative remedies before seeking judicial recourse, which is seen as a remedy of last resort. ${ }^{78}$ This might suggest that courts understand their role as ensuring tribunal decisions are publicly justified, since it is necessary for tribunals to exercise their functions before the court can properly review their decisions. However, courts have generally been reluctant to defer to these tribunals on matters of statutory interpretation ${ }^{79}$ and, instead, reassert their monopoly over law interpretation. Relatedly, courts have not always ensured robust participatory rights before environmental tribunals. For example, the Alberta Court of Appeal has upheld the tribunal's restrictive understanding of "directly affected" that is largely limited to those possessing private property rights. ${ }^{80}$ These cases suggest that, despite environmental tribunals' distinctive capacity to

\footnotetext{
${ }^{77}$ There is much variability here. Ford notes that most appeals tribunals do have a statutory right of appeal: Cristie Ford, "Dogs and Tails: Remedies in Administrative Law" In Lorne Sossin, Colleen Flood eds, Administrative Law in Context 2d ed Emond Montgomery Publications Ltd, 2013) 85 at 103-4[Ford $]$. However, the Alberta and British Columbia environmental appeals tribunals do not have statutory rights to appeal: DeMarco \& Valdoon, supra note 64 at 137-8. Though it is unclear if this makes a tangible difference to the intensity of review in light of recent Supreme Court jurisprudence: McLean v British Columbia (Securities Commission), 2013 SCC 67, [2013] 3 SCR 895.

${ }^{78}$ Ford, supra note 77 at 108-112; See also $R v$ Consolidated Maybrun Mines Ltd, [1998] 1 SCR 706 (where the court holds that a company cannot 'collaterally attack' an administrative order by way of criminal defence, when it did not avail itself of appeal to the environmental tribunal) and Western Canada Wilderness Committee $v$ British Columbia (Forests, Lands and Natural Resource Operations) 2014 BCSC 808, [2014] BCWLD 3659 [Western Canada Wilderness] discussed further below.

${ }^{79}$ For example: Greater Vancouver (Regional District) v Darvonda Nurseries Ltd, 2008 BCSC 1251, [2008] BCJ No 1788 at paras 58-65 (applying Dunsmuir and looking to a long line of precedent of a standard of correctness when reviewing the $\mathrm{BC}$ environmental tribunal's interpretations of its home statute); Montague v Ontario (Ministry of Environment), 12 CELR (3d) 271, [2005] OJ No 868 Montague (2005) at para 14 (where the court stated that the members of the tribunal "do not require any legal or scientific experience or training. They are merely appointed by the Lieutenant Governor in Council..." and reviewed the tribunal's decision on a standard of correctness.) Though courts typically acknowledge the scientific expertise of tribunals and will defer on questions of fact or mixed fact and law.

${ }^{80}$ Kostuch, supra note 73; Kelly v Alberta (Energy Resources Conservation Board), 2009 ABCA 349, [2009] AJ No 1161.
} 
require front line environmental decisions to be publicly justified, courts do not view them as participants in the rule-of-law project.

In sum, one important insight from the environmental emergency framework is that environmental tribunals are keystones for the rule-of-law project. They are not only technical review bodies nor are they legislated obstacles to a judicial resolution, rather they are participants in the collective project of ensuring that environmental decisions are publicly justified on the basis of rule-of-law values. As such, they are worthy of more academic attention than they currently receive. A second major challenge, however, requires thinking beyond the adjudicatory model. As we have seen, environmental decision-making encapsulates a wide variety of forms - regulation-making, programmatic decisions, licensing or approvals — and these do not always lend themselves to review through an adjudicatory process. These issues are referred to as polycentric, ${ }^{81}$ meaning that they raise complex and interconnected concerns that cannot be comprehensively assessed in the context of adjudicatory proceedings. The following section introduces the Forest Practices Board, not to hold it up as a panacea to all of these issues, but simply as an example of the kind of creative institutional design that has the potential to foster a "culture of justification" 82 in the complex environmental context.

\section{ii. The Forest Practices Board}

In response to escalating forestry controversies, the British Columbia legislature created the Forest Practice Board (FPB), the province's independent forestry watchdog. ${ }^{83}$ The

\footnotetext{
${ }^{81}$ Lon Fuller, "The Forms and Limits of Adjudication” In Kenneth L Winston, The Principles of Social Order: Selected Essays of Lon L Fuller Rev ed, (Oxford - Portland, OR: Hart Publishing, 2001) at 113.

${ }^{82}$ David Dyzenhaus, "The Legitimacy of Legality" (1996) 46 UTLJ 129 [Dyzenhaus "Legitimacy"].

${ }^{83}$ Northwood Inc v British Columbia (Forest Practices Board), 2001 BCCA, 2001 CarswellBC 389 at para 8 (quoting legislative Hansard) [Northwood].
} 
FPB is an administrative body, in the specific sense that it does not have an adjudicative, or dispute-resolving function. Rather, the FPB has "broad powers to investigate public complaints, to oversee the audit process and to report to the public." ${ }^{84}$ It is what one commentator has called a "hybrid institution" 85 because it exercises a number of different regulatory functions. The Board is comprised of members with forestry expertise, typically professional foresters but also biologists, and lawyers with experience in forestry regulation. ${ }^{86}$ Any individual can file a complaint, request an investigation, or petition the FPB to bring an appeal before the Forest Appeals Commission, but the FPB can also do all of these things on its own initiative. ${ }^{87}$ The Board has extensive powers to compel information, summon witnesses, and enter premises to carry out its investigative and reporting functions. ${ }^{88}$ However, the FPB's remedial powers are limited to giving recommendations resulting from their audit and complaint procedures. ${ }^{89}$ On judicial review, the British Columbia Appeals Court has upheld the FPB's generous interpretation of its auditing powers. ${ }^{90}$ As we will now see, the FBP played an important role in the province's response to the mountain pine beetle epidemic, demonstrating how an unconventional institution can maintain public justification under the conditions of the environmental emergency.

Recall that the mountain pine beetle epidemic precipitated a controversial government response. The primary response strategy was to facilitate widespread logging in order to

\footnotetext{
${ }^{84}$ Ibid.

${ }^{85}$ Mary Liston, "Evolving Capacities: The BC Representative for Children and Youth as a Hybrid Model of Oversight" In Laverne Jacobs, Sasha Baglay eds, The Nature of Inquisitorial Processes in Administrative Regimes (Aldershot: Ashgate Publishing, 2013).

${ }^{86}$ Forest and Range Practices Act, SBC 2002, c 69 s 136(2). [FRPA] The legislation doesn't specify 'merit'. Current members are professional foresters, but past members have been lawyers, biologists and accountants: Forest Practices Board online <http://www.fpb.gov.bc.ca/FPB_Profile.htm >.

${ }^{87}$ FRPA, supra note 86 ss 83, 124, 125.

88 Ibid. ss 123-5.

89 Ibid. s 131.

90 Northwood, supra note 83.
} 
recoup as much economic revenue from the forests before the timber was destroyed by the beetle. Initially, it was also thought that strategically-placed and well-timed clear-cuts could control the spread of the beetle. ${ }^{91}$ This required fast-tracked and highly coordinated decisions that were exempted from the ordinary administrative requirements. ${ }^{92}$ The public's response to the government's strategy was not overwhelmingly positive. In many corners, it was seen as a cash grab; a reckless move that masked the deep problems plaguing the forestry industry. ${ }^{93}$ Environmentalists worried about the long-term health of the forests and foregone ecological benefits of allowing an insect infestation to run its course. ${ }^{94}$ Concerned citizens believed profitdriven forestry companies were capitalizing on the relaxed administrative requirements and generally chaotic gold-rush conditions to harvest more desirable, but unaffected tree species. ${ }^{95}$ These decisions were not contested in court; indeed, it is clear they are poorly suited for judicial resolution and would have warranted exceptional judicial deference. Instead, the Forest Practices Board addressed them.

On its own initiative, the Board reviewed the initial harvesting strategy adopted by the government to determine whether it was reasonable. It exercised its special reporting function to comprehensively assess an issue of public concern. ${ }^{96}$ After conducting an independent analysis of the epidemic and possible harvesting models, the FPB concluded that the government's harvesting strategy was ineffective and recommended a different strategy -

\footnotetext{
${ }^{91}$ Harry Nelson, "Does a Crisis Matter? Forest Policy Responses to the Mountain Pine Beetle Epidemic in British Columbia" (2007) 55 Can J of Ag Econ 459.

92 Bark Beetle Regulation BC Reg 286/2001.

${ }^{93}$ Ben Parfitt, Battling the Beetle: Taking Action to Restore British Columbia's Interior Forests (Vancouver: Canadian Centre for Policy Alternatives, 2005).

${ }_{94}$ Ibid. Larry Pynn, "Part One: In The Wake of a Plague” Vancouver Sun (10 Sept 2012), online: Vancouver Sun <http://www.vancouversun.com/technology/Part+wake+plague/5800904/story.html >.

${ }^{95}$ Larry Pynn, "Part Four: 'It Looks Like Armageddon”" Vancouver Sun (10 Sept 2012) online: Vancouver Sun <http://www.vancouversun.com/travel/Part+Four+looks+like+Armageddon/5814799/story.html>.

${ }^{96}$ Forest Practices Board, Evaluating Mountain Pine Beetle Management in British Columbia, FPB/SR/20 (Victoria: Government of British Columbia, 2004) [FPB Evaluating].
} 
harvesting attacked timber rather than green timber — which the government then adopted. Similarly, the Board relied on its special reporting powers to issue a series of reports that examined the ecological impacts of the province's mountain pine beetle response and highlighted the detrimental effects the response was having on, in particular, biodiversity conservation ${ }^{97}$ and water quality. ${ }^{98}$ Moreover, the Board has monitored the mountain pine beetle response over the long term and has recommended further changes to forest management policy now that efforts to salvage beetle-killed timber have dwindled. ${ }^{99}$

These reports demonstrate how this special reporting function allows the requirement of public justification to be maintained across a much wider range of environmental decisions. The FPB operates in a way that allows even general policy decisions - regulations and legislation - to reflect the requirements of public justification. The issues taken up by the FPB in the wake of the mountain pine beetle crisis could not have been subject to effective review by the courts; they were politically loaded and highly technical. Yet the FPB's expertise and willingness to question the government's approach provided a review mechanism for complex policy decisions that generated a government response.

This special reporting function has many merits. It enables a more systematic approach to reviewing environmental issues because it does not entirely depend on an individual complaint that may narrowly focus on one issue while ignoring underlying systemic problems. The Board can respond to environmental issues based on their perceived necessity, can address

\footnotetext{
${ }^{97}$ Forest Practices Board, Biodiversity Conservation During Salvage Logging in the Central Interior of BC, FPB/SR/35 (Victoria: Government of British Columbia, 2009).

${ }_{98}$ Forest Practices Board, The Effect of Mountain Pine Beetle Attack and Salvage Harvesting on Streamflows, FPB/SIR/ 16 (Victoria: Government of British Columbia, 2007)

${ }^{99}$ Forest Practices Board, Timber Harvesting in Beetle-Affected Areas, FPB/SR/44 (Victoria: Government of British Columbia, 2014).
} 
them holistically, and can monitor these issues over time. It possesses inquisitorial powers, which allow it to overcome limitations of depending solely on interested parties marshalling their own evidence.

The FPB also investigated individual complaints about the mountain pine beetle response. The Board responded to complaints about the necessity of harvesting in beetleaffected areas and the consistency of this harvesting with publicly-developed land use objectives. ${ }^{100}$ It investigated the use of large clearcuts that exceeded the requirements ordinarily required by legislation, ${ }^{101}$ and the alleged haphazard use of arsenic-based pesticides to control the beetle. ${ }^{102}$ Concerned citizens or NGOs-who may not have had a significant enough stake in the matter to meet the strict "directly affected" standing requirements of many environmental tribunals_-brought all these complaints. The unrestricted nature of who can file a complaint enables the FPB to focus directly on the merits of the government policy or decision.

In response to complaints about government decision-making, the FPB has a policy that outlines the questions that guide the inquiry into whether the decision is both fair and reasonable. ${ }^{103}$ The policy suggests that the Board operates on a principle of deference. It directs the Board to determine whether the government's decision was "consistent with sound forest practices, ... achieve $[\mathrm{d}]$ the intent of the Forest Practices Code and was... based on an adequate

\footnotetext{
100 Forest Practices Board, Balancing Community Needs and Pine Beetle Logging in the Robson Valley, FPB/IRC/78 (Victoria: Government of British Columbia, 2002).

101 Forest Practices Board, Approval of Large Cutblocks to Control Mountain Pine Beetle in the Robson Valley, FPB/IRC/69 (Victoria: Government of British Columbia, 2002) [FPB Cutblocks].

${ }^{102}$ Forest Practices Board, Nadina Beetle Treatments, FPB/IRC/99 (Victoria: Government of British Columbia, 2004) [FPB Nadina].

103 "Discretionary Decisions" online: Forest Practices Board <http://www.bcfpb.ca/board/policies/complaintinvestigations/discretionary-decisions $>$.
} 
assessment of available information." ${ }^{104}$ In addition, the FPB reviews the government's "consideration of the potential impact of a decision on those directly affected and on the general public, as well as the need for effective and efficient administration." 105 The mountain pine beetle-related complaints reflect this policy. The FPB investigations exposed government decisions that prioritized private concerns above sound forest practices ${ }^{106}$ and criticized decisions that were excessively technocratic and thus undermined the public accessibility of forest decision-making. ${ }^{107}$ Moreover, these examples show that the Board takes these investigations seriously, and uses these investigations to comment broadly on matters of public importance. So, for example, even where a permit for pesticide use was justified (as determined by a different appeals tribunal), the Board cautioned the government that scientific uncertainty about the pesticide suggested it should rely on alternate methods of beetle control. ${ }^{108}$

The story of the FPB is not all good, to be sure. If not formally captured by the forest industry, its close on-the-ground relationships with the forest companies and professional foresters runs this risk. ${ }^{109}$ This suggests that maintaining a broadly-conceived public interest mission will always be an uphill battle. And, indeed, the primarily technocratic focus of forest management does retain its grip on the Board's reports. While the FPB nicely sets out a policy for reviewing government decisions, which combines fairness and reasonableness in a manner consistent with common law constitutionalism, this policy has not permeated its special reporting function. Its special reports on the mountain pine beetle response are solely

\footnotetext{
104 Ibid.

105 Ibid.

${ }^{106}$ FPB Cutblocks, supra note 101.

${ }_{107}$ FPB Nadina, supra note 102.

108 Ibid. at 7.

109 This risk was raised in an early Royal Commission: Peter H Pearse, Timber Rights and Forest Policy in British Columbia (Victoria: Royal Commission on Forest Resources, 1976) at 364-5.
} 
concerned with the wisdom of the government's policy and fail to address the processes by which the decision was made.

The judicial perspective on the FPB is also somewhat mixed. Early in the Board's institutional life, the British Columbia Court of Appeal, in a nice example of deference as respect, upheld the Board's generous interpretation of its auditing powers. ${ }^{110}$ Noting that the Board is "uniquely positioned to see what is happening on the ground" and that it is limited to giving recommendations, ${ }^{111}$ the Court of Appeal allowed the Board a robust role in reporting on forest practices that went beyond ensuring formal compliance with the legislation. More recently, however, the British Columbia Supreme Court was content to substitute its own opinion for the FPB, despite holding that the Board was the appropriate forum for review. In Western Canada Wilderness, the Court held that the Board was in the best position to assess the claim that the Minister of Forests must issue a protective order for the endangered Coastal Douglas Fir community. ${ }^{112}$ Nonetheless, the Court held that the regulations delegated the Minister discretion to issue this order (or not). ${ }^{13}$ In doing so, it gave the Minister's decision "the stamp of legality" without requiring that the Minister publicly justify his decision. The Court was right to conclude that the Board, and not the Court, was the appropriate forum for ensuring the Minister's decision was publicly justified. But by leap-frogging the Board, the Court denied the Board's status as a participant in the rule-of-law project. ${ }^{114}$ From the perspective of common law constitutionalism, the Court's role is to ensure the Board's decision

\footnotetext{
110 Northwood, supra note 83.

$111 \mathrm{Ibid}$. at para 22 (adopting the lower courts reasons).

112 Western Canada Wilderness, supra note 78 at para 30.

${ }^{113}$ Because this was a claim for mandamus, the Court reviewed the Minister's interpretation of the regulations and upon agreeing that it conferred a discretion, did not review the exercise of that discretion: Ibid. at paras 73-87.

${ }^{114}$ See also Red Mountain Residents and Property Owners Assn v British Columbia (Ministry of Forests, British Columbia Forest Service, Arrow Forest District), 2001 BCSC 1142, 40 CELR (NS) 117 for another example of leap-frogging. The FPB declined to review a decision partially on the basis that judicial review had already been sought. The role of the Board is not discussed in the case.
} 
is publicly justified and it cannot perform this function until the Board has an opportunity to exercise its jurisdiction.

Despite these somewhat mixed messages, the FPB provides an interesting and unique example of the kind of institutional innovation that can maintain the requirement of public justification across a range of diverse environmental decisions. ${ }^{115}$ The creation of the FPB and indeed the fact that it has persisted even despite dramatic changes to provincial forest regulation — can be understood as a commitment by the legislature to the rule-of-law project. From this perspective, the Board plays a key role in ensuring that forestry decisions are publicly justified.

\section{Part II. Deliberative Democracy, Experimentalism, \& Institutional Design}

We have now seen how a common law constitutional understanding of the rule of law can provide meaningful constraints on the exercise of discretionary environmental powers. The requirement of public justification, and the necessity of creative institutional design that follows from this requirement in emergency conditions, has much promise to patch up the legal black and grey holes in Canadian environmental law. The question for this Part is what happens when discretion is not an aberration - as in the case of the mountain pine beetle response -

\footnotetext{
115 The closest provincial analogue to the FPB is the Alberta Environmental, Monitoring, Evaluation and Reporting Agency, an independent scientific body that provides "open and transparent access to scientific data and information on the condition of Alberta's environment," established under the Protecting Alberta's Environment Act, SA 2013, c P-26.8. See AEMERA online: <http://aemera.org//>. This Agency is too new at the time of writing to offer any detailed analysis. For some preliminary observations see: Shaun Fluker, "Protecting Alberta's Environment Act: A Keystone Kops Response to Environmental Monitoring and Reporting in Alberta” (2 January, 2014) ABLawg online: <ablawg.ca>. At the Federal level, Canada has specialized Auditor General for environmental issues, the Commissioner of the Environment and Sustainable Development: Online: Office of the Auditor General of Canada <http://www.oag-bvg.gc.ca/internet/English/cesd_fs_e_921.html>. The Commissioner issues annual reports to Parliament and responds to individual petitions. I am not the first to suggest that an ombudsman plays a role in upholding the rule of law. See: Trevor Buck, Richard Kirkham, \& Brian Thompson, The Ombudsman Enterprise and Administrative Justice (Farnham: Ashgate Publishing, 2011) at 26-8 (on its potential for upholding rule of law values, but how this is an uneasy fit with traditional theories of constitutionalism).
} 
but is rather the central feature of a regulatory regime, as we saw in Chapter 4. Is the requirement of public justification capable of operating nonetheless? We will see that the affirmative answer to this question lies at the intersection of common law constitutionalism and democratic experimentalism. Through democratic experimentalist institutional design, environmental governance can be made subject to the requirements of the rule of law.

The FPB continues to play a central role in this part of the story. As we saw in the previous chapter, in the wake of the mountain pine beetle epidemic, the British Columbian legislature enacted major reforms to the regulation of forest practices in the province. It went from command-and-control regulation to performance-based regulations that impose loose planning requirements on forest companies prior to harvest. The FPB has been a major critic of the revised regulatory scheme, enacted under the Forest and Range Practices Act (FRPA). ${ }^{116} \mathrm{We}$ will see in this Part that the criticisms set out by the FPB align with the ideals of democratic experimentalism. By examining these criticisms and proposed reforms in light of democratic experimentalist ideals, I will argue that it is possible for results-based governance under the FRPA to fulfill the requirement of public justification. In other words, the FPB's further contribution to the rule-of-law project lies in its ability to articulate how public justification can be maintained even in "post-bureaucratic"117 settings.

\section{A. The FPB's Role Under the FRPA}

The FPB originated under the Forest Practices Code, which set out detailed and comprehensive rules directing forest practices in the province. Under this legislation, the Board

\footnotetext{
${ }^{116}$ FPRA, supra note 86.

${ }^{117}$ Charles F Sabel \& William H Simon, "Due Process of Administration: The Problem of Accountability" (2014) Stanford Public Law Working Paper, online: SSRN

<http://papers.ssrn.com/sol3/papers.cfm?abstract_id=2507280> ["Police Accountability”].
} 
had a strict compliance mandate that included ensuring that both government and industry complied with the detailed code. When the legislature introduced the FRPA, its results-based legislation, the Board was retained, but the way it performed its watchdog function had to change. The new legislation precipitated a decrease in the number of complaints investigations and the Board's involvement in reviews and appeals ${ }^{118}$ - understandable given the legislation's shift away from formal compliance. But over the same period the Board has increased the number of audits and special reports produced annually, suggesting that the Board has subtly redefined its role.

The FPB has become a major critic of the FRPA and its results-based scheme. The Board is currently undertaking a comprehensive investigation of the use of Forest Stewardship plans ('plans'), the key regulatory requirement under the FRPA, to assess whether these plans enable public review and comment, contain measurable and enforceable commitments, whether they are likely to meet the stated performance objectives, and whether the plans reflect any innovation or improvement over time. ${ }^{119}$ Preliminary investigations of the FPB suggest this is not the case. In particular, the Board has highlighted four major concerns with the existing regulatory scheme.

First, the Board has consistently observed that existing plans do not tend to contain measurable and enforceable commitments. ${ }^{120}$ The FRPA contains only minimal requirements

\footnotetext{
118 Trends were observed by reviewing the FPB's Annual Reports between 2014 and 1996. These are general trends; inconsistencies in reporting and internal procedures for conducting, in particular, complaints investigations make it difficult to draw firm conclusions.

119 Forest Practices Board, Great Expectations - Forest Stewardship Plans in BC, Terms of Reference for Special Investigation (Victoria: Government of British Columbia, 2013) [FPB Great Expectations].

${ }^{120}$ Forest Practices Board, A Review of the Early Forest Stewardship Plans Under FRPA, FPB/SR/28 (Victoria:

Government of British Columbia, 2006) at 2 [FPB Early FSP]; Forest Practices Board, Community Watersheds:
} 
for the content of the plans, requiring only that a plan include the "intended results and strategies" in relation to the objectives under the FRPA. ${ }^{121}$ These results and strategies must be "consistent" with the objectives; they need not demonstrate that they will in fact achieve these objectives. ${ }^{122}$ The FPB has argued that this allows the approval of generic plans in which results and strategies contained in the plans are often set out in vague and unmeasurable terms. ${ }^{123}$ The Board observed the tendency of early plans to favour unmeasurable strategies, rather than concrete results. For example, one strategy reads: "The holders of this FSP [plan] will make reasonable efforts to communicate development plans to affected First Nation bands." ${ }^{124}$ Such expansive language undermines the enforceability of a regulatory scheme that otherwise prohibits harm to the environment outside the scope of approved plans. ${ }^{125}$ Therefore, the Board has recently recommended that: "When approving forest stewardship plans, [public officials] should ensure that results and strategies contained in the plans are: a) consistent with government objectives; and b) measurable and verifiable.” 126

Second, the FPB has observed that the plans do not enable meaningful public participation. ${ }^{127}$ The regulatory regime requires public notice-and-comment periods, but only

From Objectives to Results on the Ground, FPB/SIR/40 (Victoria: Government of British Columbia, 2014) at 12 [FPB Watersheds].

${ }^{121}$ FPRA, supra note 86 at s 5. (Also requires various technical points such as listing the licenses which the plan covers, and including a map).

122 Ibid.

${ }^{123}$ FPB Early FSP, supra note 120 at 7.

${ }^{124} \mathrm{Ibid}$. at $10-11$.

${ }^{125}$ It can be assumed that legislation is intended to be enforceable. The FPRA, supra note 86 contains specific references to enforceability: at s 46 (prohibition of harm to environment other than what is in approved plans), $\mathrm{s} 21$ (requirement to carry out the contents of the plans), ss 71 and 72 (administrative penalties for non-compliance), and s 87 (criminal charges for non-compliance). See also: Forest Practices Board, A Decade in Review: Observations on Regulation of Forest and Range Practices in British Columbia, FPB/SR/46 (Victoria: Government of British Columbia, 2014) at 12-13 (summarizing that number of significant non-compliance findings in audits has dramatically increased in recent years) [FPB Decade].

${ }^{126} \mathrm{Ibid}$. at 2 .

127 Forest Practices Board, Public Involvement in Forest Management Planning in BC, Board Bulletin Volume 15 (Victoria: Government of British Columbia, 2013) at 4-5 [FPB Public] (noting that the adequacy of public involvement is a common theme in complaints). 
mandates that the plan is made available to interested and motivated individuals who contact the individual forest company. ${ }^{128}$ In the event that members of the public do reach out to a forest company, they are likely to find a vague plan that does not disclose the details of how any given individual might be affected by future forest practices. The plans are not required to show where logging roads will be built or where harvesting will occur. These details are left to 'site plans,' which are not subject to government approval nor public notice-and-comment requirements. ${ }^{129}$ The Board has further criticized the use of technical and legal language that can make it difficult for the public to understand the content of the plan. ${ }^{130}$ The FPB maintains that " $[\mathrm{t}]$ here is an onus on licensees to provide appropriate information and opportunities, and on the public to make their interests and concerns known to licensees." 131

Third, the Board has criticized the existing results-based objectives for prioritizing timber harvest, by making most of the other objectives subject to the condition that they do not unduly reduce the amount of timber harvested from British Columbia's forests. ${ }^{132}$ The FPB has noted that there is much interest "for a more balanced consideration of the full range of forest resource values and the economic and ecological necessity of doing so." 133 And has suggested that, " $[\mathrm{a}] \mathrm{t}$ the very least, there are likely to be areas of the province in which different values might take priority for ecological, economic, community safety or aesthetic reasons and that might require an objective that is less constrained." ${ }^{134}$ The Board has suggested that the

\footnotetext{
128 Forest Planning and Practices Regulation, BC Reg 14/2004 at ss20-22 [FPPR].

${ }^{129}$ FRPA, supra note 86 at s 10 ; FPB Public, supra note 127 at 4.

130 Ibid. at 3; FPB Early, supra note 120 at 12.

${ }^{131}$ FPB Public, supra note 127 at 1 . It further recommends that companies go above and beyond the legislated notice-and-comment requirements to "maintain or improve public acceptance." (at 6).

${ }^{132}$ FPPR, supra note 128 at ss 5-9.1

${ }^{133}$ FPB Early, supra note 120 at iv (p 4 of cover letter).

${ }^{134}$ Ibid.
} 
government refine the objectives to allow for variation. ${ }^{135}$ Further, the Board has observed that there is no centralized resource for viewing the entire list of results-based objectives — they are split amongst regulations and orders-in-council. Indeed, the FPB has noted that in many cases local land-use planning objectives have not been converted into binding objectives under the Act. ${ }^{136}$ The Board has recommended that "Government should establish a single, publiclyaccessible website that sets out all government objectives under FRPA.”137

Finally, the FPB has expressed its concern that that monitoring and enforcement of the existing regulatory scheme is currently under-resourced. The British Columbia government has committed to the "Forest and Range Evaluation Program," a long-term program that assesses the effectiveness of the FRPA, determines whether performance objectives are being achieved, and identifies opportunities for improvement. ${ }^{138}$ But this is labour- and cost-intensive work and the FPB has highlighted the significant decreases in budget, 139 staff, and inspections $^{140}$ in recent years, which have imperilled rigorous analysis and raised concerns that the analysis that is occurring is not being used to improve the regulations. ${ }^{141}$ The Board has recommended that "Government and licensees... support a robust effectiveness evaluation program." 142

\footnotetext{
135 Ibid.

${ }^{136}$ FPB Watersheds, supra note 120 at 8.

${ }_{137}$ FPB Decade, supra note 125 at 2.

138 Forest and Range Evaluation Program Strategic Plan 2011-2013 (Victoria: Government of British Columbia, 2011); British Columbia Ministry of Forests, "Forest and Range Evaluation Program Logic Model" <https://www.for.gov.bc.ca/ftp/hfp/external/!publish/frep/library/FREP_Logic_Model-oct2007.pdf>.

139 FPB Decade, supra note 125 at 22.

140 Forest Practices Board, Monitoring Licensees' Compliance with Legislation, FPB/SIR/37 (Victoria: Government of British Columbia, 2013).

${ }^{141}$ FPB Watersheds, supra note 120 at 15-17 (observing the wide variation in the quality of professional assessments of forest practices).

${ }^{142}$ FPB Decade, supra note 125 at 3.
} 
The Board's reports respond to many of the concerns raised in Chapter 4 about the FRPA's wide scope for arbitrariness. While the Board does not use the language of the 'rule of law' nor 'public justification,' this is what underpins its recommendations: under the existing regulatory scheme that the $\mathrm{FPB}$ aims to reform, important public decisions about forest practices are not publicly justified. As we will now see, the Board's recommendations are remarkably consistent with a governance-oriented branch of deliberative democracy, known as democratic experimentalism. After introducing democratic experimentalism, I will argue that reimagining the FRPA along the democratic experimentalist lines, as suggested by the FPB, would also supply a framework conducive to governance under the rule of law.

\section{B. Democratic Experimentalism}

Democratic experimentalism is a school of thought that seeks to provide a democratic framework for responding to complex regulatory problems that are not easily addressed through traditional top-down regulation. Heavily influenced by the philosophical pragmatism of Charles Peirce and John Dewey, and finding inspiration in the practices of successful and adaptive private firms, democratic experimentalists argue that post-bureaucratic regulation can provide flexibility and induce learning in a way that responds to complex and fast-changing contemporary regulatory problems. ${ }^{143}$ These successful regulatory practices are: benchmarking, simultaneous engineering and error correction. ${ }^{144}$ Benchmarking requires regulators to continually survey existing regulatory models or approaches to identify superior approaches. Simultaneous engineering means that there are multiple regulators simultaneously implementing their own problem-solving approach. And error correction requires regulators to

\footnotetext{
143 "Police Accountability", supra note 117 at 3-4.

${ }^{144}$ Michael C Dorf \& Charles F Sabel, "A Constitution of Democratic Experimentalism" (1998) Columbia Law Review 267 at 287 [Dorf \& Sabel].
} 
continuously monitor, revise and improve their regulatory approach in light of new information. They argue that practices of benchmarking, simultaneous engineering and error correction can generate new information that provides a necessary foundation for continual public deliberation over both means and ends, and the relationship between the two.

In their classic account of democratic experimentalism, Dorf and Sabel argue that these features can be realized through a combination of extensive national oversight with significant local autonomy over problem-solving. ${ }^{145}$ Local governance units, through rigorous citizen participation, determine the best approach to any given regulatory problem. National monitoring bodies pool information about local experimentation and provide syntheses of which regulatory approaches are working and which are not, which in turn enable local units to revise their regulatory approaches. ${ }^{146}$

Dorf and Sabel argue that democratic experimentalism requires simple but profound shifts in the roles of our institutions of government. They envision a much reduced role for the legislature where the legislature is responsible for identifying framework goals and delegating the necessary authority to local decision-makers to realize these goals along with the conditions that they "publicly declare their goals and propose measures of their progress, periodically refining those measures through exchanges among themselves and with the help of correspondingly reorganized administrative agencies." 147 Government agencies, they argue, take on the important role of monitoring these local experiments, establishing "rolling rules,"

\footnotetext{
${ }_{145}$ Ibid. at 287-8 (summarizing their position).

146 They also argue that democratic experimentalism can work at the supranational level: Charles F Sabel \& Jonathan Zeitlin, "Learning from Difference: The New Architecture of Experimentalist Governance in the EU" (2008) 14 European L J 271, Christine Overdest \& Jonathan Zeitlin, "Assembling an Experimentalist Regime: Transnational Governance Interactions in the Forest Sector" (2014) 8 Regulation \& Governance 22 [Overdest \& Zeitlin] (arguing that the Forest Stewardship Council has many features of a global experimentalist institution).

147 Dorf \& Sabel, supra note 144 at 288.
} 
identifying leaders and laggards, and providing support for building capacity within localities and private firms. Under this model, agencies are not distant rule-makers, but hands-on collaborators that play a crucial role in ensuring that local decision-makers are working toward achieving legislative goals. The courts, too, play an important, though altered role. Judicial review, they argue, "takes place at a metalevel” because experimentalist courts do not review the actual decisions but rather the reasons decision-makers articulate for reaching these decisions. ${ }^{148}$ Reasons must contain a form of peer review, justifying the decision on the basis of what is implemented elsewhere. And, in some circumstances, decisions might ideally be subject to actual peer review by a distinct reviewing body that stands alongside the court. ${ }^{149}$

Democratic experimentalists advocate "a two-fold transformation in judicial decisionmaking" that mirrors Dyzenhaus' account of common law constitutionalism. First, democratic experimentalists attempt to avoid an all-or-nothing approach to judicial review that requires courts to either blindly defer or to intervene and second-guess the judgment of the administrative decision-maker. ${ }^{150}$ The practice of giving reasons is again key. Dorf and Sabel argue that a rolling rule provides a baseline for assessing what regulatory approaches are reasonable. ${ }^{151}$ When reviewing regulatory action, the issue for the court is "whether the agency in fact undertook the kind of information organizing and coordinating effort necessary to generate rolling best-practices standards." ${ }^{152}$ When reviewing individual regulatory compliance, the issue for the court is whether deviating localities engaged in the process of benchmarking

\footnotetext{
${ }_{148} \mathrm{Ibid}$. at 399-400 (arguing that judicial review "moves in the direction of an express jurisprudence of excluded or impermissible reasons.").

${ }_{149} \mathrm{Ibid}$. at $377 f f$ (example of peer review in the nuclear safety context). They make this point explicitly in: Charles F Sabel \& William H Simon, "Epilogue: Accountability Without Sovereignty" Grainne De Burca, Joanne Scott eds, Law and New Governance in the EU and the US Hart Publishing, 2006) 395 [Epilogue].

${ }^{150}$ Dorf \& Sabel, supra note 144 at 395.

${ }^{151} \mathrm{Ibid}$. at 397.

${ }^{152}$ Ibid.
} 
necessary to determine that the best practice would not work under their local conditions. ${ }^{153}$ Where the centralized regulator and localities are able to demonstrate through reasons that they have engaged in these processes, the court must defer.

Dorf and Sabel argue that courts retain their role in interpreting and defending core constitutional norms. However, they emphasize that these fundamental norms are "always provisional in the sense that the means by which core values are both protected and ultimately defined are deliberately exposed to experimentalist understanding." ${ }^{154}$ For example, courts must set out the requirements for due process or basic requirements of participation in public decision-making. But what these requirements will look like in any given case is up to the administrative decision-maker and subject to the requirement of justification. This practice of justification should prompt courts to further refine the fundamentals of these participatory rights. Translated to Dyzenhaus' words, courts are also subject to the requirement of public justification. Courts, too, must offer reasons for their decisions, which prompt further future deliberation about whether this articulation best reflects our understanding of constitutional values and how to achieve them. Dorf and Sabel argue that "[j] $]$ udicial review by experimentalist courts accordingly becomes a review of the admissibility of the reasons private and political actors themselves give for their decisions, and the respect they actually accord these reasons." 155

Democratic experimentalism is related to but not the same as the environmental governance examples introduced in Chapter 4. Democratic experimentalism imposes much

\footnotetext{
${ }^{153}$ Ibid.

${ }^{154}$ Ibid. at 387.

155 Ibid. at 389.
} 
more exacting requirements on our public institutions. The Great Bear Rainforest Agreement combines public deliberation with scientific expertise, but is not replicated elsewhere in the province, nor are its procedures and decisions generally accessible to the public. The Forest Stewardship Council is perhaps the closest example of democratic experimentalism with its tiered institutional structure that enables experimentation at both the individual firm and national levels. The entire certification process requires continuous reporting and is overseen by the international Forest Stewardship Council governance body. Yet there is little evidence that suggests the Forest Stewardship Council is taking advantage of this democratic experimentalist design by synthesizing this massive amount of information to improve and clarify deliberations by its members. ${ }^{156}$ And, as we have seen, while the FRPA ostensibly requires forest companies to engage in the kind of goal-setting, planning and revision that is central to democratic experimentalism, it lacks the essential elements of public deliberation to make it democratic, and rigorous centralized oversight to generate constant improvement.

Much like common law constitutionalism, democratic experimentalism sets out deceptively simple requirements that, in fact, demand a high-level of ongoing commitment in practice. Democratic experimentalists readily concede there are no perfect examples of their ideals - it is always a work in progress. But they offer promising innovations in a range of settings from endangered species habitat protection, to nuclear power regulation, to community policing. The fact that these institutional experiments exist demonstrates that experimentation is possible and it suggests that we can continue this process of experimentation and learning from prior experience.

\footnotetext{
${ }^{156}$ Overdest \& Zeitlin, supra note 146.
} 
In short, democratic experimentalism requires an ongoing commitment to the practice of reason-giving. Reasons are vital for the kind of regulatory learning that democratic experimentalists imagine will put us on a better track for effective regulation. They are also vital for enabling dynamic peer review that courts and legislatures alone cannot provide. ${ }^{157}$ More than this, however, we will now see that the practice of reason-giving institutionalized through democratic experimentalist ideals can make environmental governance subject to the requirements of the rule of law.

\section{Experimentation and Public Justification}

I argue that implementing the FPB's major recommendations would align the FRPA much more closely with democratic experimentalist ideals and, in doing so, make possible public justification. To elucidate this relationship between democratic experimentalism and public justification, it is useful to disaggregate the various kinds of law that structure the FRPA regulatory process. Dyzenhaus argues that administrative law is in fact three kinds of law. ${ }^{158}$ The first is constitutive law, by which he means the statute that brings the administrative body into being and delegates its authority. In this case, it is the FRPA. Second, he delineates substantive law, or the rules and decisions made by the administrative body. The substantive law of the FRPA regime is the content of approved plans produced by forest companies as these are what, in principle, realize the results-based objectives. Third, is procedural law, or what is most often associated with administrative law: i.e., the law that governs the way that administrative bodies make their decisions. The procedural law of the FRPA is comprised of the procedures that public officials must follow before approving a plan. Dyzenhaus argues that,

\footnotetext{
${ }^{157}$ Epilogue, supra note 149 at 400.

${ }_{158}$ David Dyzenhaus, "Accountability and the Concept of (Global) Administrative Law" (2009) 2009 Acta Juridica 3 at 4 [Dyzenhaus "Accountability"].
} 
for an administrative decision to comply with the rule of law, all three of these legal dimensions must fulfill the requirement of public justification. This means that an administrative body must be the result of a public delegation of authority (constitutive law), it must publicly justify its exercise of authority (procedural law), and its justification must disclose a reasonable interpretation of the public interest (substantive law). ${ }^{159}$

\section{i. Constitutive Law (public delegation of authority)}

On its face, the FRPA, as a legislative act, is a public delegation of authority. But the FPB has made several recommendations that, if implemented, would also make this legislation consistent with democratic experimentalist ideals: namely, (1) more stringent requirements for 'measurable and verifiable' commitments in the plans, and (2) increased public involvement.

A democratic experimentalist FRPA would require greater specificity in the plans that explicitly link planned forestry practices to the performance-objectives. Democratic experimentalism would turn the current plans on their head. The objective would be to subject the content of the plans to ongoing scrutiny, not escape it. In addition to more specific results and strategies, a democratic experimentalist FRPA would subject plan-holders to rigorous reporting requirements, where reapproval would be conditional on demonstrating some learning or improvement on prior iterations of the plan. Moreover, the plans must generate true public deliberation. The limited notice-and-comment requirements of the existing scheme may enable some participation — the one-time input of public concerns — but do not enable deliberation, which entails the back-and-forth giving of reasons over the content of the plans. ${ }^{160}$

\footnotetext{
159 Ibid. at $27-8$.

160 The requirements of deliberation are taken up in more detail in Chapter 5.
} 
Democratic experimentalists might further encourage legislators to consider enacting a "penalty default rule," a strict rule that would apply to regulated firms in the event they do not develop their own plans. Democratic experimentalists have observed a penalty default rule is often necessary to induce collaboration by dominant stakeholders. ${ }^{161}$ Over time, as regulators learn from prior experience, the penalty default rule can turn into a "rolling rule" that is ratcheted up in line with industry best practices. To model this aspect of democratic experimentalism, the FRPA must create a credible threat that laggard plans will be rejected and timber harvesting will therefore be prohibited. This threat motivates plan holders to commit themselves to increasingly rigorous forestry practices. Present practice suggests that this is not the case as many companies adopt the less demanding default results and strategies. ${ }^{162}$ When companies develop their own results and strategies, the FRPA requires that public officials approve them so long as they formally comply with the Act. ${ }^{163}$ This is effectively a reverse penalty default rule, one that induces shirking and opportunism rather than continual improvement.

The FRPA is a public delegation of statutory authority, but it is flawed from the perspective of democratic experimentalism. As we will now see, these flaws are intertwined with the ability of the regulatory scheme to maintain the requirement of public justification.

\footnotetext{
${ }^{161}$ Bradley C Karkkainen, "Information-forcing Regulation and Environmental Governance" Grainne De Burca, Joanne Scott eds, Law and New Governance in the EU and the US (Portland, OR: Hart Publishing, 2006) 293.

162 FPB Early, supra note 120 at 2.

${ }^{163}$ FRPA, supra note 86 at s16. Furthermore, the determination that the plan conforms with the legislation can be made by a professional forester rather than a public official: Ibid. at s16(1.01).
} 


\section{ii. Substantive Law (justification discloses a defensible interpretation of the public interest)}

In addition to the public delegation of authority, the exercise of that authority must also meet the requirement of public justification. That is, any decision or rule by an administrative decision-maker must disclose a defensible interpretation of the public interest; for example, it cannot reflect bad faith or consideration of irrelevant factors. In the case of the FRPA, the exercise of public authority is the approval or rejection of the plan. When a plan is approved, the plan forms the reasons for the decision. If rejected, the Minister is required to offer reasons for the rejection, which also must disclose a defensible interpretation of the public interest. Given the strong statutory language that requires the Minister to approve formally compliant plans, they are virtually never rejected. ${ }^{164}$ The focus here, therefore, is on the approval of plans, which must disclose a reasonable interpretation of the public interest. The fact that the reasons for the decision — the content of the plan — are primarily in the hands of private parties suggests that we should pay particular attention to whether the FRPA complies with this dimension of the rule of law. We cannot simply assume that the interests of a private party will align with the public interest. ${ }^{165}$

We take up the issue of what counts as a reasonable interpretation of the public interest in detail in the following chapter. However, it should be clear that the conditions of the environmental emergency make this a very difficult inquiry. Scientific uncertainty means that environmental decision-makers must make decisions in the absence of a solid factual foundation.

\footnotetext{
${ }^{164}$ I found one appeal to the Forest Appeals Commission about a rejected amendment to a plan, where the parties settled on amended language: Babine Forest Products Ltd. v. Government of British Columbia, (2013) 2011-FOR006(a) (Forest Appeals Commission). Also, plans have been challenged in court for failing to consult with aboriginal peoples (e.g. Klahoose First Nation v Sunshine Coast Forest District, 2008 BCSC 1642, [2009] 1 CNLR 110). This is not to say that all plans are in fact compliant with the legislation. The FPB's investigations have revealed cases in which they are not: FPB Watersheds, supra note 120.

${ }^{165}$ Cristie Ford makes this point with respect to experimentalist design in the financial sector prior to the financial crisis: Cristie Ford, "New Governance in the Teeth of Human Frailty: Lessons from Financial Regulation" (2010) Wis L Rev 441 at 472 .
} 
What counts as the public interest in the abstract could be virtually any decision or no decision. Any forestry approval might connect to a future, unknown environmental catastrophe and thus should be prohibited; likewise any forestry approval might contribute to improving the economic conditions of the province and thus should be approved. At a purely abstract level, both extremes can reflect defensible interpretations of the public interest.

Recognizing this issue, the FPB has issued recommendations that emphasize the need for greater public involvement and for a greater commitment to the province's Effectiveness Evaluation Program, which gathers information about the plans and whether they are achieving the results-based objectives. The Board has also noted the need for redefined objectives that do not prioritize timber, as well as a publicly-accessible list of all performancebased objectives. These recommendations all align with democratic experimentalism, which argues that a public-regarding decision is one that is the product of robust deliberation, drawing on the experience of simultaneous regulatory experiments. Put differently, a defensible interpretation of the public interest is not simply the absence of bad faith and overt industry capture; rather, it must positively justify the particular approach on the basis of known best practices.

A democratic experimentalist FRPA, therefore, would institutionalize robust deliberation about the contents of each plan. This deliberation would not be constrained by prioritizing timber harvest in every case; ${ }^{166}$ indeed, it seems likely that the interest of prioritizing timber harvest would be sufficiently represented both by the forest company (plan holder) and labour unions, which have both the incentive and capacity to effectively participate

\footnotetext{
${ }^{166}$ Dorf \& Sabel, supra note 144 at 369 (noting that US National Forest policy has been plagued by the same dominance of timber harvest objectives).
} 
in the deliberations about the plan. A democratic experimentalist regime would allow each plan to specify objectives in a way that reflects the issues and interests at stake in every given reason, on the condition that these objectives and the measures to achieve them are justified through reasons that reflect benchmarking, simultaneous engineering and error detection.

This kind of reason-giving can only occur with the assistance of a centralized institution that synthesizes and reports on the effectiveness of the simultaneous experiments. The FPB's concerns about the province's existing Effectiveness Evaluation Program speak to this need. A properly functioning centralized monitoring program would produce a rolling best practices guide. And it would highlight both leaders and laggards in an effort to publicly praise and shame forest companies into doing better. Interestingly, the flexible mandate of the FPB has allowed the Board to step up where the evaluation program has fallen short. The Board has documented significant problems with plans' commitments to protecting drinking water, in particular noting that 41 of 44 plans investigated did not contain enough detail for the Board to conclude whether or not they were consistent with the performance objective. ${ }^{167}$ The Board has undertaken a comprehensive report to assess plans — across all performance objectives — to be released in the near future. ${ }^{168}$ And it has identified individual plan-holders that have gone above-and-beyond legislative requirements to ensure public involvement in forest practices. ${ }^{169}$

A democratic experimentalist regulatory regime therefore puts in place the infrastructure that allows us to discern whether a plan reflects a defensible interpretation of the public interest. This is not an abstract determination but rather is a plan that is developed in

\footnotetext{
${ }_{167}$ FPB Watersheds, supra note 120 at 2.

${ }^{168}$ FPB Great Expectations, supra note 119.

${ }_{169}$ FPB Public, supra note 127 at 5-6.
} 
conjunction with robust public participation and that pays careful attention to the practices that are working (and failing) elsewhere. When a plan reflects this kind of process and reasongiving, we can say that the approval of a plan complies with the rule of law.

\section{iii. Procedural Law (the exercise of authority is publicly justified)}

The FPB's recommendations pay particular attention to the enforceability of the contents of the plans, but do not go beyond existing administrative powers — such as inspections, penalties and offences - detailed in the legislation. Crucial to both democratic experimentalism and the requirement of public justification is a forum which allows those subject to public decisions to contest decisions when they are not perceived as justified. Judicial review provides one opportunity for contestation, but, as we have seen, courts cannot occupy the field when it comes to complex regulatory issues. As I have argued in this chapter, specialized appeal tribunals are often key to ensuring that public justification occurs, since they possess the requisite expertise to test the decision-maker's complex and technical claims. Hybrid institutions that have broader oversight functions for reviewing government regulation and policy that are not suited for quasi-judicial dispute resolution.

The combination of specialized review bodies and the court can ensure that the exercise of public authority is justified on the basis of core constitutional values. The role of the reviewing body is not to substitute its own views, but to ensure that the decision-maker has implemented a fair process and has offered defensible reasons for its decision. ${ }^{170}$ The court is

\footnotetext{
170 Dorf \& Sabel, supra note 144 at 403 ("Thus, as a matter of substance, experimentalist judging focuses on the permissibility of reasons and responses to threat to fundamental legal norms. As a matter of procedure, experimentalist judging focuses on participation; but where traditional procedural jurisprudence seeks the eternal requisites of fair process, experimentalist courts ask whether parties whose actions are challenged have satisfied
} 
still there, but in the background, playing a primarily "catalytic" role by prompting administrative decision-makers to reflect upon and articulate the norms underpinning their decisions rather than articulating and enforcing those norms directly. ${ }^{171}$

Under the existing FRPA scheme, a rejected plan can be appealed to the specialized Forest Appeals Commission, but the strict statutory language makes it unlikely that plans will be rejected. Moreover, the Forest Appeals Commission does not have a general public interest mandate and cannot hear appeals brought by general members of the public if, for example, a plan is perceived as weak or non-compliant. ${ }^{172}$ The Forest Practices Board, in its capacity as a public advocate, must bring these claims before the Commission. ${ }^{173}$ Alternatively, a claim might be brought for judicial review of a plan, which has occurred where aboriginal groups have alleged that the government has not discharged its constitutional duty to consult prior to approving a plan. ${ }^{174}$ Only in the latter case has review of an approval been successful.

A reimagined FRPA would have a clear channel for review of both approvals and rejections of plans under the FRPA. This could take many forms, but would likely be to the Forest Appeals Commission and ultimately to the court on judicial review of any decision of the Commission. We have also seen that the FPB has exercised its mandate to review government decisions that would otherwise escape effective judicial review - both in response to the mountain pine beetle epidemic, and more generally with respect to flaws in the current FRPA regime.

their obligation to grant those rights of participation revealed to be most effective by comparison with rolling best practices elsewhere.")

${ }^{171}$ Joanne Scott \& Susan Sturm, "Courts as Catalysts: Re-Thinking the Judicial Role in New Governance" (2006)

13 Colum J Eur L 565 at 567.

172 Haddock, supra note 64 at 29.

${ }^{173}$ FRPA, supra note $86 \mathrm{~s} 83$.

174 Supra, note 164. 
Key to fulfilling the procedural dimension of public justification is the effective protection of participatory rights. Canadian environmental law has a long history of closeddoor regulation and restrictive criteria to have standing before an environmental appeals board. ${ }^{175}$ While the FPB opens up this regulatory process to public scrutiny, it is not clear that it has taken a strong enough stance in calling on the government to increase the opportunities for public participation. It has repeatedly highlighted this as an issue, but has taken a much more timid stance on proposing legislative and regulatory reforms that go to the heart of the issue of fairness. ${ }^{176} \mathrm{~A}$ further issue is the FPB's limited remedial powers. The Board is limited to issuing recommendations. It does not have the enforcement powers of a tribunal or court, nor could it without radically changing its mandate and raising constitutional issues. What is clear is that the FPB cannot be the sole forum for ensuring public justification. There needs to be a realistic opportunity to contest a plan before the Forest Appeals Commission and ultimately the courts.

In short, a democratic experimentalist FRPA is also one that complies with the rule of law, understood as public justification. Democratic experimentalism provides the institutional architecture for maintaining public justification even in regulatory contexts that contain significant administrative discretion and that rely extensively on private parties for achieving legislative objectives. To return to the conclusion of Chapter 4, environmental governance need not be understood as rejection of the rule of law. Once we understand the rule of law as the requirement of public justification, democratic experimentalist institutional design can allow environmental governance to be governed by the rule of law.

\footnotetext{
${ }_{175}$ D Paul Emond, "The Greening of Environmental Law" (1990) 36 McGill LJ 742 at 748-52.

${ }^{176}$ E.g. FPB Public, supra 127 (the Board finds massive problems but only encourages companies to do better).
} 


\section{Part III. The Rule-of-Law Project}

In this section, I weave together the threads of the preceding analysis to argue for an understanding of the rule of law as a project. The rule-of-law project requires an ongoing commitment to public justification and the institutional innovation needed to make that justification possible. We will see that the rule-of-law project presupposes a particular relationship between lawmaker and legal subject, one that understands the subject as a rational and self-determining agent who is capable of actively participating in governance under the rule of law. This understanding of the individual and the relationship between lawmaker and subject emerges from the overlaps between common law constitutionalism and deliberative democracy.

The "rule-of-law project" is a phrase used by David Dyzenhaus to describe his version of common law constitutionalism. Dyzenhaus highlights two features of his understanding of the rule of law as public justification. First, the idea of a project captures a sense of collaboration, or the idea that all institutions of government are participants in the collective endeavour of realizing core constitutional values. This is not meant to suggest that each interaction between the various branches of government will be cooperative; indeed, Dyzenhaus documents how too much timidity exhibited by the courts, in particular, undermines the rule-of-law project. Rather, Dyzenhaus argues that every public institution is entitled to assume that every other public institution is committed to the rule-of-law project, such that when one institution deviates from this commitment, the others are entitled-indeed, required-to call the public's attention to 
this fact. ${ }^{177}$ Understanding the rule of law as a project also captures a second sense of the idea of a project, in which the rule of law is always viewed as a work in progress. The requirement of public justification is an aspirational account of the rule of law. It requires an ongoing commitment to public justification. The rule of law, in other words, cannot be secured simply by promulgating one-time legislative rules that formally comply with well-known rule of law features.

Despite the fact that democratic experimentalists are not primarily concerned with law or the rule of law, the concept of a rule-of-law project fits nicely with the ideals of democratic government to which they are committed. First, it is clear that realizing democratic experimentalist ideals requires institutional changes and ongoing commitments within all major institutions of government. ${ }^{178}$ They argue that democratic experimentalist institutions better reflect the separation of powers than the current concentration of power in administrative agencies because "experimentalist administration creates the mirror - the systems of information exchange and benchmarking — in which the doings of the other branches, and its own as well, are reflected for public scrutiny." ${ }^{179}$ For democratic experimentalists, courts are not passive referees but "active problem solvers." 180 Democratic experimentalism envisions a degree of institutional cooperation not contemplated nor permitted by a strict understanding of the separation of powers. Moreover, its commitment to continual regulatory improvement through means-ends reasoning provides the institutional context through which an ongoing requirement of public justification can be realized.

\footnotetext{
177 Dyzenhaus Constitution, supra note 4 at 201.

${ }^{178}$ Dorf \& Sabel, supra note 144 at 395 (noting that the problem of all-or-nothing judicial review in the US is not of the court's own making and cannot be fixed by "doctrinal assertion alone").

179 Ibid. at 439.

180 Ibid. at 401.
} 
These connections between democratic experimentalism and common law constitutionalism run deeper still. Both understand law as a two-way relationship between lawmaker and subject, an insight attributable to Lon Fuller. Fuller outlines how this relationship emerges from the formal features of law-in particular, the requirements to promulgate general, non-retrospective rules that are implemented congruently with the stated rule. ${ }^{181}$ Law is not simply a command, because the lawmaker cannot command whatever she wants. In order to make law, she can only issue commands in the form of law. Law's form-its generality, prospectivity, and congruent enforcement-make the legal subject's capacity for agency internal to law itself. ${ }^{182}$ These features of the rule of law are not mere matters of expediency. This is because, to take one example, in any given case it might be more effective for an official to issue an individualized, rather than general, command. ${ }^{183}$ Fuller argues these rule-of-law features only make sense if we understand the legal subject as capable of selfdirected action. ${ }^{184}$ The rule of law thus imposes an obligation on the lawmaker to have regard for the subject's capacity for reason and self-determination. In this sense, legal subjects are also authors of the law, for their agency imposes meaningful constraints on what a lawmaker can and cannot do.

Compliance with the rule of law, according to Fuller, is also the source of law's authority. When a lawmaker successfully makes law—-that is, by taking seriously the subject's

\footnotetext{
${ }^{181}$ Fuller, supra note 1 at 208-9; Kristen Rundle, Forms Liberate: Reclaiming the Jurisprudence of Lon L Fuller (Oxford and Portland: Hart Publishing, 2012) at 134 [Rundle] (clarifying that legal subjects are subjects of law, not subjects to law).

182 Ibid. at 10.

${ }^{183}$ Similarly it might be more effective in pursuit of a specific end for an official to command that a subject depart from a stated rule.

${ }^{184}$ Fuller, supra note 1 at 210 . Fuller later quips, "it would serve little purpose, for example, to attempt a juristic ordering of relations among the inmates of a lunatic asylum.” Ibid. at 219.
} 
agency - this gives rise to an obligation on the part of the subject to obey. ${ }^{185}$ Though Fuller refers to this as a "reciprocal" obligation on the subject, he is clear that this obligation of obedience is owed, not to the lawmaker, but to his fellow citizens. ${ }^{186}$ Fuller understands law purposively, as a framework for social interaction. ${ }^{187}$

Kristen Rundle emphasizes that Fuller's conception of the rule of law recognizes legal subjects as "responsible agents" who have the capacity to reason with the law. ${ }^{188}$ For Fuller, law properly so-called has a form that its subjects can understand and conceivably obey (or contest). As we have seen, Dyzenhaus extends Fuller's two-way relationship outward from legislative rules to the more complex inner workings of the administrative state. The requirement of public justification requires administrative decision-makers to offer reasons for their decisions. Importantly, the direction of those reasons is not only upward-and-backward to whoever previously delegated the decision-making authority. Rather, the reasons are directed at the legal subject to show that the decision-maker took the subject's interests seriously in reaching the decision. ${ }^{189}$ The rule of law, understood as public justification, thus carries with it an obligation on all public officials to make decisions in a form that respects the subject's rational capacity to engage with the law.

This understanding of the legal subject as a responsible agent is a natural fit within theories of deliberative democracy. ${ }^{190}$ At base, deliberative-democratic theory, of which

\footnotetext{
${ }^{185}$ Fuller, supra note 1 at 209, 219-220. See supra note 2 on the complexity of this issue.

${ }^{186} \mathrm{Ibid}$. at 207-8.

187 Ibid. at 208; Nigel E Simmonds, Law as a Moral Idea (Oxford: Oxford University Press, 2007 ) at 152.

188 Rundle, supra note 181 at 10.

189 Dyzenhaus “Accountability”, supra note 158 at 14.

190 Dyzenhaus "Legitimacy", supra note 82 at 163 and Hoi Kong, "Election Law and Deliberative Democracy: Against Deflation" (2015) 9 JPPL 35 at Part I. The analysis that follows closely tracks that of Kong, who has previously identified connections between Fuller and deliberative-democratic theory.
} 
democratic experimentalism is one variant, understands individuals as capable of giving and receiving reasons. In the words of leading deliberative-democratic theorists: "To deliberate with another is to understand the other as a self-authoring source of reasons and claims."191 Respecting individuals as responsible agents requires a system of governance that protects this autonomy, that is, a system in which public institutions and decisions are justified by reasons that individuals cannot reasonably reject. ${ }^{192}$

We can identify further commonalities between the public-justification conception and deliberative-democratic theory. ${ }^{193}$ Deliberative democrats suggest principles that can guide or constrain the kinds of reasons that are permissible, all of which dovetail with the publicjustification conception of the rule of law. They argue that justification requires reasons that are general ${ }^{194}$ - that is, they apply to all who are similarly affected by the decision-and reciprocal195 — that is, not based on self-interest and are accessible and comprehensible to those to whom they are directed. The scope and application of these principles are to be determined contextually, that is through actual deliberation amongst those affected by the decision. ${ }^{196}$ Furthermore, these principles have important implications for institutional design. ${ }^{197}$ For example, we would expect better quality deliberation when participants are exposed to a wide

\footnotetext{
${ }^{191}$ John Parkinson \& Jane Mansbridge, Deliberative Systems: Deliberative Democracy at the Large Scale (Cambridge: Cambridge University Press, 2012) at 11 [Parkinson \& Mansbridge].

192 Ibid. at 25; Amy Gutmann \& Dennis Thompson, Why Deliberative Democracy? (Princeton: Princeton University Press, 2004) at 3 [Gutmann \& Thompson]; Rainer Forst, The Right to Justification: Elements of a Constructivist Theory of Justice, translated by Jeffrey Flynn (New York: Columbia University Press, 2011) at 6 [Forst] (setting out criteria of generality and reciprocity). Contemporary deliberative democratic theory owes its start to Habermas, who argued that procedures of ideal deliberation give rise to the collective judgment of the people: Jürgen Habermas, Between Facts and Norms, translated by William Rehg (Cambridge: MIT Press, 1996)

[Habermas].

193 I follow Kong in highlighting these connections: supra note 190.

${ }^{194}$ Forst, supra note 192 at 6; Gutmann \& Thompson, supra note 192 at 147-8 (reasons must be moral and not prudential).

${ }^{195}$ Forst, supra note 192 at 6; Gutmann \& Thompson, supra note 192 at 147 (reasons cannot be based on selfinterest) and at 144-6 (reasons must be accessible to be mutual).

${ }^{196}$ Ibid. at 100.

197 Joshua Cohen, "Deliberation and Democratic Legitimacy" James Bonham, William Rehg eds, Deliberative Democracy: Essays on Reason and Politics (Cambridge, Mass: MIT Press, 1997) 67 at 79.
} 
range of views and when decision-makers are representative of those who will be affected by the decisions. ${ }^{198}$ Democratic experimentalists offer a specific example of the "penalty default rule" to encourage better quality deliberation by evening out pre-existing power dynamics.

Legal decisions are both the product of democratic deliberation and a site of deliberation. ${ }^{199}$ Law is the legitimate form of political action, ${ }^{200}$ but the process of converting public deliberations into law creates a "surplus value" through its compliance with the rule of law. ${ }^{201}$ This is because the form of law enables further participation by its subjects through practices of obedience and contestation. In other words, the rule of law enables further public deliberation about our most basic democratic and legal commitments and how best to achieve them. ${ }^{202}$ In this way, law is always provisional. It is part of the ongoing rule-of-law project to ensure that public decisions best reflect our core constitutional values.

As should be clear, this conception of the rule of law is democratic in a fundamentally different way than the formal conception. The formal conception gains its democratic status through the protection of the legislative monopoly over lawmaking. It tries to ensure that significant policy decisions are taken by the legislature, the public institution with the greatest claim to democratic legitimacy. And, as we saw in the first half of the thesis, it fails. Significant policy decisions are made every day by administrative decision-makers, collaborative

\footnotetext{
${ }_{198}$ Gutmann \& Thompson, supra note 192 at 146; Henry S Richardson, Democratic Autonomy: Public Reasoning About the Ends of Policy (Oxford: Oxford University Press, 2002) at 227-9 [Richardson].

${ }^{199}$ Kong, supra note 190 at 41 (noting that this is an extension of deliberative democratic theory which construes law solely as a product of deliberation); Dyzenhaus, "Legitimacy of Legality", supra note 82 at 177.

${ }^{200}$ Recall Chapter 2 and the discussion of the "compulsion of legality" at note 71 and accompanying text; Habermas, supra note 192 at 297-8 (on the legitimating conditions for law).

${ }^{201}$ David Dyzenhaus, "Preventive Justice and the Rule-of-Law Project" Andrew Ashworth, Lucia Zedner, Patrick Tomlin eds, Prevention and the Limits of the Criminal Law (Oxford: Oxford University Press, 2013 ) at 96.

${ }^{202}$ Democratic experimentalists pick up on this theme. Simon writes that the formal nature of law is desirable because it "increases the range of perspectives that can be brought to bear on the norm's revision.": William H Simon, "Toyota Jurisprudence: Legal Theory and Rolling Rule Regimes" Grainne De Burca, Joanne Scott eds, Law and New Governance in the US and the EU (Portland, OR: Hart Publishing, 2006) 37 at 48.
} 
governance bodies, and transnational organizations claiming to act in the public interest. The rule-of-law project builds democracy in from the beginning. Public justification requires a "culture of justification," 203 in which legal subjects deliberate on the content of laws and have the institutional channels to contest public decisions that do not reflect the content of these deliberations. The legislature, as a participant in the rule-of-law project, remains a source of democratic legitimacy. Even under an ideal form of democratic experimentalist design, a statutory mandate with framework goals is still necessary. But the requirement of public justification does not stop here because it imposes further obligations on all public decisions, even those taken in the depths of complex regulatory schemes. ${ }^{204}$

Moreover, it is worth noting that understanding the rule of law as an ongoing project of public justification also eschews any hardline distinction between public and private. ${ }^{205}$ The exercise of public power-public in the Deweyan sense of addressing a problem with collective consequences $^{206}$ - must comply with the requirement of public justification in order to have legal authority. Thus, it is of no significance that, in the case of the FRPA, public policy is in substance developed by forest companies, so long as the plans comply with the requirement of public justification (which, to re-emphasize, they currently do not). Similarly, the Forest Stewardship Council, the non-state transnational certification body introduced in the previous chapter, might be understood to govern through law when it complies with the rule of law requirement of public justification. Indeed, one explanation for the Forest Stewardship

\footnotetext{
203 Dyzenhaus "Legitimacy", supra note 82 at 162.

${ }^{204}$ Richardson, supra note 198 at 250 ("To prevent bureaucratic domination...we must conceive of agency deliberation as an integral part of our distributed democratic reasoning about what we ought to do. Conceiving it as such, we ought to arrange it so that it can fulfill this role.")

205 TRS Allan, Constitutional Justice: A Liberal Theory of the Rule of Law (Oxford: Claredon Press, 2001) at 11 ("It was a distinctive feature of Fuller's theory of law that he refused to limit its scope to the strictly governmental sphere, emphasizing the similarity of the most important questions about legitimate governance that arise whenever an institution seeks to regulate the affairs of its members.”)

${ }^{206}$ John Dewey, The Public and Its Problems (Chicago: The Swallow Press Incorporated, 1954) at 47 [Dewey].
} 
Council's perceived legitimacy, in the absence of any direct state involvement, could be the extent to which it complies with the public-justification conception of the rule of law. ${ }^{207}$

Deliberative-democratic theory allows us to appreciate that the public-justification conception is a superior conception of the rule of law, rather than a second-best (if necessary) alternative to the formal conception. As I have argued, what is fundamental to both theories is recognizing the rational and self-determining capacity of individuals. This encourages us to think about our public institutions as intelligent and purposive attempts to organize human affairs. ${ }^{208}$ Institutions are not static entities, nor are they purely instrumental means for implementing pre-determined ends. ${ }^{209}$ Rather, our constitutional commitments are realized through our institutions and their practices. ${ }^{210}$ Complexity in human action is presumed and therefore made internal to this conception of the rule of law. We therefore need not cling to the fiction that legal decisions proceed in a linear fashion in which the legislature sets out definitive objectives then mechanically implemented by administrative decision-makers. ${ }^{211}$ Public justification contains understandings of legal authority and legal constraint that do not falter in complex regulatory contexts.

\footnotetext{
${ }^{207}$ Jocelyn Stacey, "The Public Law of Private Governance: Assessing the Forest Stewardship Council” (Paper delivered at the Australia \& New Zealand Law \& Society Association Conference, 4 December 2014), [unpublished].

${ }^{208}$ Lon L Fuller, "Means and Ends" Kenneth I Winston ed, The Principles of Social Order: Selected Essays of Lon L Fuller Rev ed (Oxford \& Portland: Hart Publishing, 2001) 61 ["Means and Ends"] and Dewey, supra note 206 at 32. See also Richardson, supra note 198 at 250 (summarizing his position that institutional design follows from commitment to collective reasoning under conditions of uncertainty).

209 "Means and Ends", supra note 208 at 69-72. Dyzenhaus takes the common law as an exemplar of this kind of reasoning: Dyzenhaus "Legitimacy", supra note 82 at 177.

${ }^{210}$ Rundle, supra note 181 at 42 succinctly summarizes Fuller's contribution on this point: "Fuller's writings on specific forms or processes of ordering help us to see just how fundamental his interest in the connections between form and agency actually is, at the level of theoretical insight into the nature of law as a distinctive enterprise, as much as to the everyday experience of how legal processes are constituted and enlivened by the ways in which agents participate within them."

${ }^{211}$ Richardson, supra note 198 at 189 . Fuller clearly rejects this separation between means and ends: "Means and Ends", supra note 208. Reciprocal means-ends reasoning through public deliberation is central to democratic experimentalism as well, which they attribute to the philosophical pragmatism of Peirce and Dewey: Dorf \& Sabel, supra note 144 at 284.
} 


\section{Conclusion}

In this chapter, I have developed a public-justification conception of the rule of law. I traced this conception to an alternative interpretation of Dicey's constitutionalism, in which he argues that emergency powers can be subject to a robust conception of the rule of law. We saw that Dyzenhaus' elaboration of Dicey's theory provides a complete response to Schmitt's challenge. Public decisions have legal authority when they comply with the requirement of public justification. There is no exception. Creative institutional design, such as specialized appeals tribunals, can ensure public justification even under conditions of the emergency. Moreover, we saw that this conception of the rule of law already exists, albeit imperfectly, in Canadian administrative law.

I extended the public-justification conception of the rule of law in the environmental context by looking to the potential of hybrid institutions, such as the Forest Practices Board, for maintaining public justification across a diverse range of administrative decisions. I argued that, by incorporating the institutional design ideas of democratic experimentalism, even novel forms of environmental governance can comply with the requirement of public justification. The result, as we have just seen, is an understanding of the rule of law as a project, in which all institutions of government are responsible for publicly justifying their decisions on the basis of core constitutional principles.

The rule-of-law project has significant implications for environmental law in Canada. It requires: first, that all public environmental decisions are reasoned; second, that the reasons are directed to those affected by the decision; and third, that the reasons reflect core constitutional principles. These three requirements are a significant departure from the formal conception of 
the rule of law. As saw in previous chapters, the formal conception does not require that environmental decision-makers offer explicit reasons for their decisions because, under this conception, a decision has legal authority so long as it is authorized by a validly enacted statute.

The requirement of public justification has further significant implications for institutional design. The breadth and complexity of environmental decisions means that courts cannot, on their own, ensure that decisions are publicly justified. Creative institutional design is required to maintain public justification. Democratic experimentalism provides an institutional framework that enables this commitment to public justification in the environmental context. What creative institutional design will look like in any given context will vary, but what animates this creativity is a commitment to respecting and enabling the active participation of individuals in environmental governance under the rule of law. 


\section{Publicly Justifying Canadian Pipeline
Development}

\section{Introduction}

The focus of this chapter is on the reasons offered as public justification. The perspective of this chapter is that of the ideal reviewing body, equipped to assess whether an environmental decision reflects core constitutional principles. As I introduced in Chapter 5, the Supreme Court of Canada has recognized two core constitutional principles that emerge from the common law: reasonableness and procedural fairness. Both principles are highly sensitive to context. There is no uniform set of fair administrative procedures, nor is there a bright-line test for reasonableness. This chapter elaborates the principles of fairness and reasonableness for the environmental context by drawing on existing environmental principles.

The case study for this chapter is a set of highly controversial Canadian pipeline proposals. As we will see, these pipelines are controversial precisely because of their connection to possible environmental emergencies. Public concerns focus on the possibility of catastrophic oil spills in highly populated areas or sensitive ecosystems, and the contribution to global climate change by entrenching the country's commitment to Alberta oil sands exploitation. At present, four major controversial pipelines are at various stages of approval across Canada. The primary institutional actor in each decision is the National Energy Board (NEB or Board), the federal regulator that makes a determination of whether a pipeline is in the public interest. As we will see, the NEB has been caught up in a wave of Parliamentary reforms that have been unabashed in their intent to undermine environmental protection in Canada. I argue that these reforms can be understood, not only as an attempt to undermine environmental protection, but 
also an attempt to exempt pipeline approvals from the rule-of-law project. We will see that, so far, the NEB and Federal Court of Appeal have been complicit in this creation of legal grey holes. The central argument of this chapter is that, to have legal authority, these pipeline approvals must be publicly justified on the basis of fairness and reasonableness, elaborated as they need to be for the environmental context. Existing environmental principles, such as sustainable development and precaution inform this rule-of-law requirement and provide a concrete basis on which the NEB and courts can resist the creation of legal grey holes.

As we saw in Chapter 5, the public-justification conception of the rule of law is aspirational in that it requires an ongoing commitment from both public officials and the public. In this chapter we will see that it is also capable of offering specific guidance to those public institutions tasked with making complex and controversial environmental decisions. Thus, a second objective of this chapter is to offer defensible interpretations of the principles of sustainable development and precaution that respond to common critiques of these environmental principles and show how they are an integral part of the rule-of-law project in environmental law. The persistence of the formal conception of the rule of law in the environmental context, as we saw in Chapter 3, has stunted the development of these principles in Canadian environmental law. This chapter provides a rule-of-law framework in which these principles play a meaningful role in shaping environmental decisions.

The chapter contains three parts. In the first Part, I introduce the four pipeline disputes, the NEB's role in the approval process and highlight three areas of public controversy. While these controversies go to the independence, fairness and reasonableness of the NEB's approval process, I argue that existing common law principles are insufficient. On their own, they fail to 
respond to the particular issues raised in the environmental context. The second Part turns to the well-known environmental principles of sustainable development and precaution. These principles are controversial, ambiguous, and have failed to meaningfully impact the development of Canadian environmental law. I argue that they can be understood as an attempt to maintain the distinctive relationship between legal subject and state that the publicjustification conception of the rule of law makes possible. Interpreting these principles consistently with deliberative-democratic theory preserves the individual's status as a responsible agent capable of reasoning with the law. We will see that, properly understood, these environmental principles inform the common law requirements of reasonableness and fairness. In the final Part of the chapter, I return to the NEB case study in detail. Relying on this understanding of reasonableness and fairness, I argue that the NEB has failed to publicly justify its decisions in several significant respects.

\section{Part I. The Pipelines, the NEB and their Problems}

With the dramatic increase in Alberta oil sands development, Canada's NEB has gone from a relatively uninteresting technical regulatory body to a regular front-page feature of national newspapers. Unprecedentedly, its Chairperson embarked on a cross-country public relations tour, explaining the board's mandate to the Canadian public, quelling public concerns, and attempting to redeem the Board's reputation. ${ }^{1}$ This current state of affairs is the result of the NEB's mandate to oversee a suite of major pipeline proposals that transverse the country.

\footnotetext{
${ }^{1}$ National Energy Board, Press Release "NEB Chair's Cross-Country Engagement begins Monday in Atlantic Canada” (23 Jan 2015), online: NEB <https://www.neb-one.gc.ca/bts/nws/nr/2015/nro4-eng.html>; "Pipeline regulator losing trust" Editorial, Winnipeg Free Press (14 May 2015), online: Winnipeg Free Press <http://www.winnipegfreepress.com/opinion/editorials/Pipeline-regulator-losing-trust-303822661.html>.
} 
These four major proposed pipelines (depicted in Figure 1) are now household names. ${ }^{2}$ All would carry bitumen from the Alberta oil sands and are part of an informal, but transparent, national energy policy to dramatically increase oil sands production. ${ }^{3}$ Developing the oil sands has proven controversial in large part because of its significant environmental impacts. Extracting bitumen from oil sands is an energy- and water-intensive process that produces up to 4.5 times the amount of greenhouse gas emissions as conventional crude. ${ }^{4}$ It results in the toxic contamination of potable water, stored in tailings ponds or injected underground to be permanently removed from the water cycle. ${ }^{5}$ Downstream communities are perceived as hot spots for rare forms of cancer. ${ }^{6}$

\footnotetext{
${ }^{2}$ TransCanada's Keystone XL project has generated the most international heat, but this has largely been in the United States with respect to the Presidential Permit required for the construction of the American portion of the pipeline. The Canadian approval of Keystone XL, granted by the NEB in 2010, passed without notice: In the Matter of TransCanada Keystone Pipeline GP Ltd (March 2010), OH-1-2009, online: NEB <https://www.nebone.gc.ca/index-eng.html>.

${ }^{3}$ Combined the four pipelines have the capacity to transport 3 million barrels of oil per day. The Premiers of the Canadian provinces released a "Canadian Energy Strategy" that commits to expanding pipeline development and oil sands production, however, it contains no details on how this will be achieved: The Council of the Federation, Canadian Energy Strategy (The Council of the Federation, 2015), online: CBC <http://s3.documentcloud.org/documents/2 167896/canadian-energy-strategy.pdf>.

4. Pembina Institute, "Oilsands 101: Climate Impacts" online: Pembina <http://www.pembina.org/oilsands/os 101/climate>.

${ }_{5}^{5}$ Pembina Institute, “Oilsands 101: Tailings” online: Pembina <http://www.pembina.org/oilsands/os 101/tailings>; Pembina Institute, “Oilsands 101: Water Impacts” online: Pembina <http://www.pembina.org/oil-sands/os 101/water>.

${ }_{6}^{6}$ There are conflicting expert reports on this. The Alberta provincial government released a report indicating only marginally increased cancer rates: Alberta Health Services, "Cancer Incidence in Fort Chipewyan Follow-Up Report” (24 March 2014), online: Alberta Health Services <http://www.albertahealthservices.ca/poph/hi-pophsurv-cancer-overview-fort-chip-2014-03-24.pdf $>$. The community commissioned a report by the University of Manitoba which associates cancer with the consumption of traditional wild foods affected by oil sands contamination: Environmental and Human Health Implications of Athabasca Oil Sands (7 July 2014), online: One River News <http://onerivernews.ca/health-study-press-release-2014/>.
} 


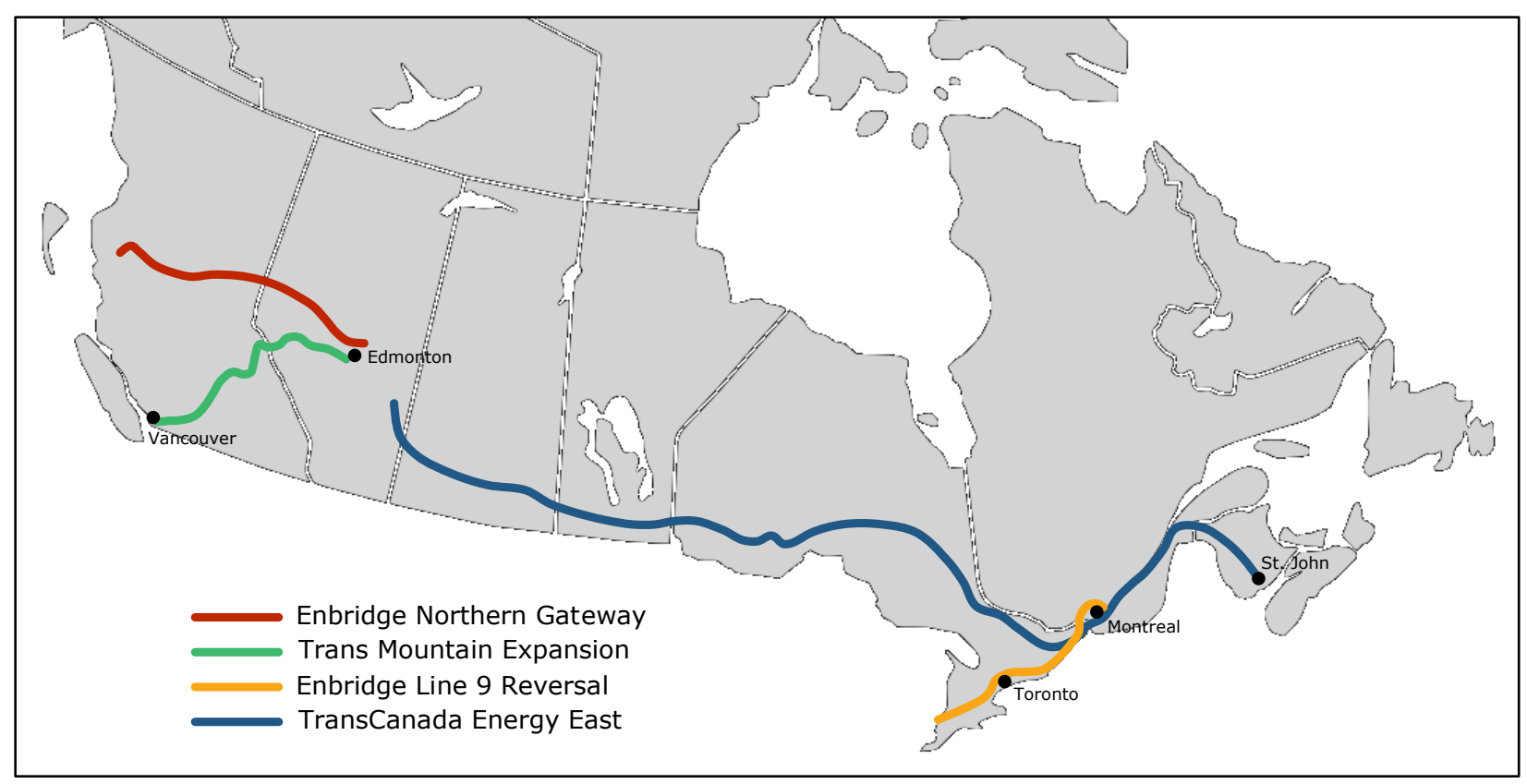

Figure 1. Major Canadian Pipeline Proposals $2015^{7}$

Each pipeline on its own is a significant undertaking. Three pipeline proposals include the construction of port facilities to transport the bitumen by tankers to international markets. ${ }^{8}$ The Energy East pipeline is the longest proposed pipeline in the history of the Board, ${ }^{9}$ running from Alberta to New Brunswick. Line 9 runs through Toronto and Montreal, the Trans Mountain Expansion through Greater Vancouver, some of the most heavily populated land in Canada. In addition, the Northern Gateway pipeline would traverse unceded Aboriginal territory, ${ }^{10}$ the ecologically-sensitive Great Bear Rainforest ${ }^{11}$ and would have tankers shipping heavy crude through notoriously tricky navigable waters currently subject to a tanker

${ }^{7}$ Credit for this figure goes to Matthew Mitchell.

${ }^{8}$ Northern Gateway, Trans Mountain and Energy East.

${ }^{9}$ National Energy Board, 2014 Annual Report to Parliament (Calgary: Government of Canada, 2015), online: NEB <http://www.neb-one.gc.ca/bts/pblctn/nnlrprt/2014/nnlrprt2014-eng.pdf > at 2 .

10 The Yinka Dene Alliance, a coalition of six First Nations, issued a powerful statement that the Northern Gateway Pipeline would violate their indigenous laws: Yinka Dene Alliance, Save the Fraser Declaration (2013), online: Save the Fraser <http://savethefraser.ca/>. The Northern Gateway Pipeline approval is currently the subject of numerous applications for judicial review: Forest Ethics Advocacy Association v Canada (Attorney General), 2014 FCA 182. The hearing has been scheduled for fall 2015.

11 The same region subject to the Great Bear Rainforest Agreement that was the subject of Chapter 4. 
moratorium. ${ }^{12}$ At present, it is unclear whether spill clean up measures for conventional crude will be as effective for bitumen. ${ }^{13}$

These pipeline proposals engage a common set of institutional practices at the NEB. The NEB regulates interprovincial and international pipelines and power-lines. For the purpose of this chapter, its primary function is to advise the Governor in Council (Cabinet) on whether interprovincial pipeline proposals are "in the public convenience and necessity." ${ }^{14}$ It has a public interest mandate, which it describes as "promoting safety and security, environmental protection, and efficient energy infrastructure and markets in the Canadian public interest within the mandate set by Parliament." 15

The NEB's pipeline assessment process is governed by a combination of the National Energy Board Act (NEBA) and the Canadian Environmental Assessment Act, $2012(C E A A) .{ }^{16}$ The process for each pipeline proposal, in broad strokes, follows the same steps. ${ }^{17}$ The pipeline proponent submits an application for the required certificate to construct a pipeline. The Board reviews this application, determines the scope of assessment by releasing a list of issues that it will consider, and it opens an application period for members of the public who are interested in

\footnotetext{
${ }_{12}$ Roland Priddle, Federal Public Review of the Moratorium on BC Offshore Oil and Gas Activities: Public Review Panel Government of Canada, 2003), online: NEB <https://docs.neb-one.gc.ca/>.

${ }_{13}$ This became evident after the massive Enbridge spill into the Kalamazoo River. See, e.g., United States Environmental Protection Agency, "Oil Cleanup Continues on Kalamazoo River (June 2013), online: EPA $<$ http://www.epa.gov/enbridgespill/pdfs/enbridge-fs-20130624.pdf> (describing the need to dredge river sediment to remove submerged oil).

${ }_{14}$ National Energy Board Act, RSC 1985, c N-7 at ss 2, 52 [NEBA].

${ }^{15}$ In the Matter of Enbridge Pipelines Inc (March 2014), OH-002-2013, online: NEB <https://docs.neb-one.gc.ca/> at 5 [Line 9 Decision].

${ }^{16}$ Canadian Environmental Assessment Act, 2012, SC 2012, c 19, s 52 [CEAA].

${ }^{17}$ There are two differences worth noting: First, the Line 9 approval was not subject to the $C E A A$, although the NEB conducted an assessment that included environment, socio-economic and land matters as well as accidents and emergency response. The NEB was the final decision-maker for the Line 9 approval, it did not require Cabinet approval. The Northern Gateway Pipeline recommendation by the NEB happened in conjunction with a Joint Review Panel (JRP), convened under the CEAA. The terms of this JRP can be found here: $<$ http://gatewaypanel.review-examen.gc.ca/clf-nsi/hm-eng.html>. Two members of the JRP were sitting NEB members, the third was appointed by the federal Minister of Environment.
} 
participating in the NEB's hearing. Once the NEB has determined the proponent's application package is complete, it issues a hearing order that details the process it will follow for assessing the project application. We will see in a moment that numerous public concerns emerge from the details of this assessment process. After this process is complete the Board issues a recommendation report to Cabinet with conditions that should follow in the event Cabinet decides to approve the project.

This decision-making process is mired in public controversy and legal disputes that raise questions about the fairness, reasonableness and independence of the NEB's decision. I reserve detailed analysis of these issues for Part III. In order to give some context for the elaboration of environmental principles that follows in Part II, however, I first identify the issues that call into question the NEB's compliance with the requirement of public justification and the limitations in existing common law doctrine for responding to these concerns.

\section{A. Fairness}

The perceived fairness of the NEB's process has been jeopardized by recent amendments to the NEBA that require the NEB to prioritize efficiency and timeliness of its decision-making over fairness in carrying out its assessment. The Act also delineates two categories of persons eligible for public participation. As a result of these changes, the NEB is now assessing major pipelines without an oral hearing or oral cross-examination of the proponent's written evidence and is administering a two-step application process for determining whether interested parties have standing to participate in NEB hearings. 
The lack of oral hearing is a stark departure from the NEB's past practice for pipeline proposals, and from previous environmental assessments under the $C E A A$ for major project approvals. ${ }^{18}$ It raises questions about the ability of the NEB to fulfill its mandate of providing an expert report and recommendation to Cabinet since public intervention is the primary mechanism for probing the proponent's information about the benefits and risks of the project. An oral hearing, however, is not generally a requirement of procedural fairness. ${ }^{19}$ The requirements of procedural fairness have been developed with respect to the individual directly subject to state action - in this case, the pipeline proponent. In the present case the deficiency in procedural fairness is less about the project proponent and intervenors and more about the public at large that is subject to the NEB's process and ultimately Cabinet's decision. ${ }^{20}$ Controversial, complex and significant project approvals raise the question of whether the public has any right to procedural fairness. If so, in some instances, a public hearing may be the only process that can fulfill this requirement.

The NEBA requires that the NEB grant standing to those "directly affected" by the pipeline decision. ${ }^{21}$ It also delegates the NEB discretion over whether it considers comments

\footnotetext{
${ }_{18}$ See Meinhard Doelle, "CEAA 2012: The End of Federal EA As We Know It?" (2013) 24 JELP 1 for an overview of the recent, controversial changes to federal environmental assessment.

${ }^{19}$ Khan $v$ University of Ottawa (1997), 34 OR (3d) 535, [1997] OJ No 2650 (recognizing an exception to this rule where credibility is the decisive issue because a face-to-face exchange is what allows the decision-maker to determine whether the applicant is credible. In Black $v$ Advisory Council for the Order of Canada, 2013 FCA 267, 64 Admin L R (5th) 76, the Federal Court of Appeal dismissed a demand for an oral hearing. It held that the content of procedural fairness was on the low end of the spectrum because, in part, the administrative body did not have a judicial or adversarial process and only had an advisory function to the Governor in Council. In a rare case reviewing the NEB's procedure, the FCA held that the NEB was required to hold a hearing on the conditions imposed on an approved project. But the Court clearly stated that the NEB was "master of its own procedure" in deciding how to hold this hearing.

${ }^{20}$ Robert Leckey, Contextual Subjects: Family, State, and Relational Theory (Toronto: University of Toronto Press, 2008) at 224-238 [Leckey] (pointing out that much existing scholarship that comments favourably on the common law evolution of fairness ignores the greater public interest. He argues that in some cases, such as regulated industries, this will require more distance between the company and decision-maker).

${ }^{21}$ NEBA, supra note 14 at s.55.2.
} 
from those with information or expertise relevant to the decision. ${ }^{22}$ The NEB has held that "directly affected" excludes those with a "mere" public interest. ${ }^{23}$ It has also excluded interested parties on the basis that it - the NEB - is the expert and not the person claiming to have relevant expertise or information. It is clear that the "directly affected" language of the statute is a poor fit with the nature of environmental issues, which are complex, interconnected and potentially wide in geographic and temporal scope. At common law, however, the requirement that procedural fairness extend to those directly affected by the decision has favoured concrete and significant interests - typically property interests - a position affirmed by the NEB and upheld by the Federal Court of Appeal on review. ${ }^{24}$ The courts have not recognized a common law right to public participation in Canadian administrative law. ${ }^{25}$

The NEB's hearing process restricts public participation and is only public in the thin sense that the thousands of written documents involved in each hearing are available online. There are thus questions about whether the NEB's public interest mandate can be fulfilled by a process which eliminates oral cross-examination and only guarantees participatory rights to those with affected private property interests. Indeed, in instances of major regulatory

\footnotetext{
${ }^{22}$ Ibid.

${ }^{23}$ Procedural Update No. 2 - Ruling on Participation and Updated Timetable of Events (22 May 2013), OH-002-2013 [Line 9], online: NEB: <https://docs.neb-one.gc.ca/> at 7 [Line 9 Participation]. In the Trans Mountain hearing, the NEB allowed Trans Mountain the opportunity to comment on who should be granted standing. This seemed to have the effect of a motion on the proper interpretation of s.55.2, as the applicants for standing were then given the opportunity to respond. The NEB held that, since Trans Mountain did not object to any specific applicants, applicants had to show "reasonable probability that they have a specific and detailed interest that was sufficiently affected": Ruling on Participation (2 April 2014), OH-O01-2014 [Trans Mountain], NEB: <https://docs.nebone.gc.ca/> at 5 (pinpoint to header page numbers) [TMX Participation].

${ }^{24} \mathrm{Ibid}$. at 4 . Sometimes a private property interest is not even sufficient: Line 9 Participation, supra note 23 at 7 , upheld in Forest Ethics Advocacy Association and Sinclair v National Energy Board, 2014 FCA 245 [Sinclair]. See also: Paul Craig, Public Law and Democracy in the United Kingdom and the United States of America (Oxford: Claredon Press, 1990) at 27 (noting the "common-law preoccupation with traditional rights").

${ }^{25}$ Andrew Edgar, "Procedural Fairness for Decisions Affecting the Public Generally: A Radical Step towards Public Consultation?" (2014) 33 Univ Tas L Rev 56 (arguing in the Australian context that this is a natural extension from existing procedural fairness common law doctrine). Cf Administrative Procedures Act, Pub L No 79404, 60 Stat 237 (1946) (codified as 5 USC s 553) (US) (statutory requirement for notice-and-comment prior to rulemaking).
} 
decisions with significant long-term effects on Canadian energy policy, climate policy and longterm impacts on the communities and ecosystems through which the pipelines travel, we would expect that exclusion of the public must be explicitly justified.

\section{B. Reasonableness}

The second set of issues arising from the NEB pipeline processes pertains to the scope and adequacy of the NEB's assessment of the pipeline proposal. In particular, there is significant public outcry over the Board's refusal to consider the environmental effects of upstream production and downstream use of bitumen. In particular, climate activists criticize the Board for refusing to assess climate impacts that inevitably result from facilitating oil sands production. Numerous potential intervenors have been denied standing on the ground that they seek to address these 'irrelevant' issues, that is, the proposed pipelines' connection with upstream and downstream uses. They have argued unsuccessfully before the NEB and the Federal Court of Appeal that the Board's narrow interpretation of its mandate and restriction on participation is both unreasonable and a violation of their Charter protection of freedom of expression, ${ }^{26}$ and right to not be deprived of life, liberty or security of the person except in accordance with the principles of fundamental justice. ${ }^{27}$

The NEB maintains that, despite its broad discretion to determine the scope of its assessment (i.e. the specific issues that affect its determination), the $N E B A$ and $C E A A$ do not

\footnotetext{
${ }^{26}$ National Energy Board, Ms Lynne M Quarmby and others - notices of motion dated 6 and 15 May 2014 (2 October 2014), Order OH-O01-2014 Ruling No 34 [Trans Mountain], NEB: <https://docs.neb-one.gc.ca/>, leave to appeal sought Quarmby v. Attorney General of Canada, [2015] SCCA No 113 (QL) File No 36353. [TMX Section 2 Motion]. The NEB's first opportunity to hear the Charter claim was in the Trans Mountain process. However, applicants for judicial review had previously unsuccessfully argued that the NEB process violated their s.2(b) right: Sinclair, supra note 24.

${ }_{27}$ National Energy Board, Mr LD Danny Harvey - notice of motion dated 12 August 2014 (19 August 2014) OH-0012014 Ruling No 29 [Trans Mountain], online: NEB <https://docs.neb-one.gc.ca/> [TMX Section 7 Ruling]
} 
confer the authority to consider upstream or downstream effects. ${ }^{28}$ As many intervenors and observers argue, the Board's reasoning is a remarkable display of actively "unimagining" the pipelines' possible effects. ${ }^{29}$ The need for these pipelines to ensure continued oil sands development and well-functioning energy markets are crucial components of the NEB's recommendations in favour of the pipelines. ${ }^{30}$ Yet, the interconnected and wide-ranging environmental effects of major pipeline projects suggest that it will be reasonable for the NEB to draw some clear line with respect to the scope of its assessment. And, indeed, the Federal Court of Appeal has upheld the NEB's interpretation of its mandate as falling within a range of reasonable outcomes. ${ }^{31}$ At the same time, however, this determination demands a justification for considering the economic benefits that flow from upstream production and downstream use of oil sands, while excluding the potential environmental costs. Simply pointing to the openended legislation provides no such explanation.

Participants have also argued that the NEB's consideration of a possible catastrophic oil spill is also inadequate. They argue that, with respect to the Northern Gateway Pipeline, the assessment considered only the likelihood of a spill and not the potentially severe consequences should one, however unlikely, occur. ${ }^{32}$ In the Line 9 and Trans Mountain Expansion hearings,

${ }^{28}$ Compare NEBA, supra note 14 s 52(1)(a), CEAA, supra note 16 s 19 (the definition of environmental effects includes: (a) land, water and air, including all layers of the atmosphere) with National Energy Board, Motions requesting the Board include in the List of Issues the environmental and socio-economic effects associated with upstream activities and downstream use (23 July 2014), OH-001-2014 Ruling No 25 [Trans Mountain], online: NEB $<$ https://docs.neb-one.gc.ca/> [TMX List of Issues].

${ }^{29}$ Dayna Nadine Scott, "Situating Sarnia: "Unimagined Communities" in the New National Energy Debate" (2013) 25 JELP 81 [Scott].

${ }^{30}$ Considerations: Report of the Joint Review Panel for the Enbridge Northern Gateway Pipeline Volume 2 (2012), available online: Gateway Panel <http://gatewaypanel.review-examen.gc.ca/> at 335 [JRP Volume 2].

${ }_{31}$ Sinclair, supra note 24 at para 69 ("Nothing in the Act expressly requires the Board to consider larger, general issues such as climate change"). This argument will be tested again in the Federal Court of Appeal in the Northern Gateway review. The Northern Gateway approval was subject to the CEAA, supra note 16 such that the issues on review differ slightly from those in Sinclair.

${ }^{32}$ Memorandum of Fact and Law of the applicant Federation of British Columbia Naturalists carrying on business as BC Nature (22 May 2015) [copy on file with author] [BC Nature]. 
intervenors have criticized the Board for not requiring the proponents to develop and disclose site-specific emergency response plans. ${ }^{33}$ When pre-existing emergency plans were available, the NEB allowed the proponent to heavily redact their contents. ${ }^{34}$ This means that, at the time of approval, the proponents' emergency response strategies have not been scrutinized by the $\mathrm{NEB}$, the intervenors, or the public.

The adequacy of the NEB's assessment fits uncomfortably with much judicial elaboration of the requirement of reasonableness. ${ }^{35}$ The NEB's assessment in each case is extensively reasoned. The very product of the assessment process is a detailed document, on the order of hundreds of pages. In carrying out this task the NEB is operating squarely within its field of expertise. At the same time, however, the failure to demand further information on the consequences of an environmental disaster and on how a project proponent would respond in such a case undermines the purpose of the exercise. The current pipeline proposal hearings raise the concern that the $\mathrm{NEB}$ is not satisfactorily carrying out its role as an expert advisory body with respect to this central issue.

\section{Independence}

The fairness and reasonableness of the NEB's decisions are coloured by mounting evidence that the NEB is effectively captured by industry, that is, it caters to the energy

\footnotetext{
${ }^{33}$ Line 9 Decision, supra note 15 at 58.

${ }^{34}$ National Energy Board, Province of British Columbia (Province) notice of motion dated 5 December 2014 (15 January 2015), OH-O01-2014 Ruling No 50 [Trans Mountain], online: NEB <https://docs.neb-one.gc.ca/> at $4[T M X$ Redaction Ruling].

${ }_{35}^{5}$ See, e.g., Alberta (Information and Privacy Commissioner) v Alberta Teachers' Association, 2011 SCC 61, [2011] 3 SCR 654 and Newfoundland and Labrador Nurses' Union v Newfoundland and Labrador, 2011 SCC 62, [2011] 3 SCR 708 at paras 12-14 (finding that it is appropriate for the Court to infer reasons that could have been offered).
} 
industry and does not fulfill its broader public interest mandate. ${ }^{36}$ While there have been no systematic studies assessing possible regulatory capture, critics point to the fact that the Board is comprised largely of energy experts. It has no experts in environmental assessment, spill risk assessment, or public health. ${ }^{37} \mathrm{~A}$ repeated concern among many intervenors in the NEB hearings is that the Board is far too willing to rely on untested information provided by the project proponent, and is too quick to dismiss intervenor requests for more information. ${ }^{38}$ Absent some obvious statement or conduct by a Board member, however, it is difficult to imagine how a claim of more insidious institutional bias might be successful on judicial review. Courts have been reluctant to inquire into the operational realities of administrative decisionmakers, preferring instead to examine the applicable statutory framework. ${ }^{39}$

Further concerns have arisen from potential interference by the executive. The NEBA grants extraordinary powers to both the Chairperson and Minister to intervene in a hearing, for example to remove a Board member who is holding up the assessment. ${ }^{40}$ Indeed, the legislation allows the Minister to direct the Chairperson to declare a pipeline to be in the public interest without having even completed an assessment. ${ }^{41}$ Such a threat might seen remote but for the inflammatory remarks by the Minister of Natural Resources. On the opening day of the

36 "National Energy Board's impartiality over pipeline decisions questioned" (5 November 2014), online: CBC $<$ http://www.cbc.ca/m/touch/canada/newbrunswick/story/1.2824507>; Marc Eliesen, "View: Energy executive blasts Kind Morgan review as "fraudulent," quits" (3 November 2014), online: The Tyee <http://thetyee.ca/Blogs/TheHook/2014/11/03/VIEW-energy-exec-blasts-Kinder-Morgan-quits/> [Elisen].

${ }^{37} \mathrm{Ibid}$. One current member is a toxicology expert, but he is not a member on any of the pipeline panels.

${ }^{38} \mathrm{BC}$ Nature, supra note 32; Eliesen, supra note 36 (stating that of 2000 questions posed by intervenors, the NEB dismissed $95 \%$ of them and did not require the company to respond. I was not able to fact-check this claim). See also supra note 23 where I noted the NEB's unusual request that the company comment on who should be able to participate.

${ }^{39}$ Bell Canada v Canadian Telephone Employees Association, 2003 SCC 36, [2003] 1 SCR 884. Discussed in Laverne Jacobs, "Tribunal Independence and Impartiality: Rethinking the Theory after Bell and Ocean Port Hotel -- A Call for Empirical Analysis" Laverne Jacobs, Anne L Mactavish eds, Dialogue Between Courts and Tribunals - Essays in Administrative Law and Justice (2001-2007) (Montreal: Les Editions Themis, 2008) 43.

${ }^{40} \mathrm{NEBA}$, supra note 14 ss 6, 52(8). Note that it further deems all evidence heard prior to change to be heard after the change.

${ }^{41}$ This is the combined effect of s6 and s52(8). 
Northern Gateway Pipeline public hearings, the Minister declared his support for the pipeline and denounced pipeline opponents as foreign-funded, environmental ideologues. ${ }^{42}$ These comments "constructed a frame in which the submissions of affected communities... were discredited in advance." ${ }_{43}$ Moreover, the NEB actually acted upon the sentiment of these comments, if not on the comments themselves. Subsequent freedom of information requests revealed that the NEB (although not sitting panel members) coordinated efforts between the RCMP and CSIS (Canadian Security Intelligence Service) to spy on peaceful activities of environmental and aboriginal groups and further shared the information with industry. ${ }^{44}$

Together, the allegations of industry capture and executive interference suggest that the NEB is not able to effectively carry out its role of providing recommendations on the public interest. Taken as a whole, it is reasonable to conclude that the hearings are a something of a sham, an empty exercise in which the recommendation is weighted in favour of approval and, moreover, precedes a decision that the executive is determined to take in any event. If this is the case, then the NEB offers only a façade of legality. Its practices are not publicly justified and, moreover, its failure undermines the ability of Cabinet to discharge its rule-of-law obligation to publicly justify its final decision should it approve a pipeline.

The current institutional practices at the NEB are all consistent with the subtext of recent changes to the NEB's governing legislation, which were transparent in their attempt to

\footnotetext{
42 "An open letter from Natural Resources Minister Joe Oliver” (9 January 2012), online: Globe and Mail <http://www.theglobeandmail.com/news/politics/an-open-letter-from-natural-resources-minister-joeoliver/article4085663/>.

${ }^{43}$ Scott, supra note 29 at 106 (speaking specifically about aboriginal communities affected by Line 9, but it applies more broadly).

${ }^{44}$ Shawn McCarthy, "CSIS, RCMP monitored activist groups before Northern Gateway hearings" (21 November 2013), online: The Globe and Mail <http://www.theglobeandmail.com/report-on-business/industrynews/energy-and-resources/csis-rcmp-monitored-activists-for-risk-before-enbridge-hearings/article 15555935/>.
} 
stack the deck in favour of pipeline approvals. But what is key to the argument that follows in this chapter is that Parliament did not do this explicitly. Rather, these legislative changes maintained a process with many of the trappings of the rule of law. Federal authority to approve an interprovincial pipeline is preconditioned by an expert advisory body conducting a public process, with a statutory mandate to consider the environmental and socio-economic effects of a project. These elements open up the possibility of maintaining the rule-of-law project, understood as the requirement of public justification. As we saw in Chapter 5, understanding the rule of law as the requirement of public justification requires all institutions of government to resist the creation of legal grey holes. That is, unless statutory language definitively exempts the NEB from rule-of-law requirements, it must do its best to publicly justify its decisions within its institutional constraints. And where it acquiesces to the creation of a legal grey hole, the institution tasked with review is entitled to intervene.

This next Part turns to the content of public justification. As we have just seen, it is not clear that the existing common law requirements of reasonableness and fairness attend to the realities of environmental problems. The evolution of procedural fairness at common law still reflects a focus on individual interests, typically infringements of private property rights or individual liberty. The long history of judicial abstinence from legislative issues, as we saw in Chapter 3, lingers in the form of reluctance on the part of judges to directly engage with the real world operations of regulators on what are seen as policy issues. While reasonableness is a malleable concept, the uncertainty surrounding environmental effects means that virtually any decision can be reasonable in the abstract. At present, it is unclear whether a reviewing court would require the NEB to further consider specific issues within its sphere of expertise in light of an already extensively reasoned recommendation. Common law principles, however, are not 
fixed. They are sensitive to context. We will now see that, in the environmental context, two candidate environmental principles allow us to elaborate these common law requirements.

\section{Part II. In Defence of Environmental Principles}

I now introduce and defend two environmental principles: sustainable development and precaution. We will see that the requirements of these principles are ambiguous. Their seemingly common sense aims - such as developing within ecological limits - quickly dissolve whenever applied to specific contexts. Critics allege "these principles tend to be malleable and vacuous, providing political and legal decision-makers with more room, not less, to craft results that they prefer...." ${ }^{45}$ I argue that this critique is misguided because it fails to appreciate these principles as part of the rule-of-law project of public justification. Environmental principles can be understood as an attempt to safeguard the distinctive relationship between legal subject and state that the rule-of-law project makes possible, while also taking into account the challenging conditions of the environmental emergency.

Recall from Chapter 5 that public justification constitutes a distinctive legal relationship between lawmaker and legal subject. Rule-of-law requirements presuppose the subject's status as a responsible agent, someone who is capable of understanding and obeying or contesting the law. Lawmakers demonstrate that they respect this status through the requirement of public justification, that is, by justifying their decisions on terms that legal subjects cannot reasonably reject. One of the sources of these "terms" is the common law constitution and, in particular, principles of fairness and reasonableness. We saw that the Supreme Court of Canada's decision in Baker reflected this public-justification conception of the rule of law. The Supreme Court

\footnotetext{
${ }_{45}$ Bruce Pardy, "Environmental Assessment and Three Ways Not to Do Environmental Law" (2010) 21 JELP 139 at 148 .
} 
held that Mavis Baker was entitled to an open process, in which she had the possibility of influencing the outcome, and reasons that demonstrated she was not treated arbitrarily by the State. In other words, she was recognized as a responsible agent, capable of understanding and obeying or contesting the law. ${ }^{46}$

We also saw in Chapter 5 that there is significant overlap between the requirement of public justification and theories of deliberative democracy. Both understand lawmaking as an essential site of public deliberation where law is both the product of public deliberation and the basis for further deliberation. I argued that reason-giving and appropriate review mechanisms are vital components of public justification. Both are necessary for legal subjects to "reason with" the law, to participate in ongoing deliberations about whether each case really reflects the core constitutional values of the community.

From the discussion in Chapter 5, we can distill three commonalities between the public-justification conception and theories of deliberative democracy. ${ }^{47}$ First, they share an understanding of the individual as a responsible agent capable of engaging in the ongoing project of collective governance. Second, they share central guiding principles, such as generality, and argue that these principles should lead to specific institutional designs. And, third, they share a pragmatic orientation that requires an ongoing commitment to reflection, deliberation, and revision in order to better approximate the ideals of a deliberative democratic system governed by law.

\footnotetext{
${ }^{46}$ Leckey, supra note 20 at 215-6 (arguing that the Supreme Court had in mind a thicker account of Mavis Baker, still, as a contextually embedded legal subject).

${ }_{47}$ See also Hoi Kong, "Election Law and Deliberative Democracy: Against Deflation" (2015) 9 JPPL 35 at $40-41$.
} 
I now argue that we can understand sustainable development and the precautionary principle as attempts to maintain this relationship between legal subject and state in light of profound environmental challenges. These are complex principles and the shared features of deliberative democracy and public justification cannot provide definitive definitions. ${ }^{48}$ What they can provide, however, are the contours of these environmental principles and allow us to eliminate some of their persistent and confounding interpretations. We will then see how these environmental principles interact with common law requirements of fairness and reasonableness.

\title{
A. Sustainable Development
}

\author{
"Sustainable development is development that meets the needs of the present without \\ compromising the ability of future generations to meet their own needs." ${ }^{\prime 9}$
}

Sustainable development is a concept that aims to integrate ecological limits, development and equity within all public decision-making. ${ }^{50}$ The Brundtland Commission

\footnotetext{
${ }^{48}$ See Alice Woolley, "Legitimating Public Policy" (2008) 58 UTLJ 153 at 176-7 (defending deliberative democracy as an orienting theory capable of offering some guidance on public process, despite its vagueness and contested elements)

${ }^{49}$ World Commission on Environment and Development, Our Common Future (Oxford: Oxford University Press, 1987) at 43 [WCED].

${ }^{50}$ Note the debate about whether SD is a principle, interstitial norm, its own body of international law. Whether it is its own stand-alone legal principle is highly contested. Many have argued that it is far more complex than this: ${ }^{\square}$ perhaps its own body of law (Marie-Claire Cordonier Segger \& Ashfaq Khalfan, Sustainable Development Lare: Principles, Practices, \& Prospects (Oxford: Oxford University Press, 2004) [Sustainable Development Law]), an 'interstitial' legal norm that modifies other primary norms (Vaughn Lowe, "Sustainable Development and Unsustainable Arguments" A Boyle, D Freestone eds, International Law and Sustainable Development: Past Achievements and Future Challenges (Oxford: Oxford University Press, 1999) 19 at 31), or a discourse (John S Dryzek, The Politics of the Earth: Environmental Discourses 3d ed, (Oxford: Oxford University Press, 2013) at 147 [Dryzek]). Its close relationship to principles such as polluter pays, and the precautionary principle suggests that it may be more of an umbrella concept (Daniel Barstow Magraw \& Lisa D Hawke, "Sustainable Development" Daniel Bodansky, Jutta Brunnee, Ellen Hey eds, The Oxford Handbook of International Environmental Law (Oxford: Oxford University Press, 2008) 613 and Christina Voigt, Sustainable Development as a Principle of International Law (Leiden: Martinus Nijhoff Publishers, 2009) [Voigt] at 37). My primary concern here is how sustainable development might interact with existing common law norms in the domestic context. I recognize that this is a
} 
(quoted above) popularized the concept. It was the first major international effort to understand the interrelationship between poverty, development and environmental degradation, and the first to recognize the need for intergenerational equity. ${ }^{51}$ Central to sustainable development are the ideas of needs - the essential needs of the poor - and limits the physical limits of the Earth to provide for these needs over the long-term. ${ }^{52}$ The concept recognizes the injustice of historical patterns of development on developing countries and on future generations that will be immensely constrained by current wasteful production and consumption practices.

Sustainable development is arguably the most influential concept in environmental law worldwide. ${ }^{53}$ Virtually every country and every sector of social life has embraced it. ${ }^{54}$ Sustainable development is incorporated into countless international agreements ${ }^{55}$ and domestic legislation around the world. ${ }^{56}$ It is central to the idea of corporate social

narrow focus though it may have much broader implications for the development of the concept of sustainable development.

${ }^{51}$ WCED, supra note 49 at 43.

${ }^{52}$ Ibid.

${ }^{53}$ William M Lafferty, "The Politics of Sustainable Development: Global Norms for National Implementation" (1996) 5 Environmental Politics 185 at 185 [Lafferty]; Stepan Wood, Georgia Tanner, \& Benjamin J Richardson, "What Ever Happened to Canadian Environmental Law?" (2011) 37 Ecology L Q 981 at 992 [Wood et al].

${ }^{54}$ Klaus Bosselmann, The Principle of Sustainability: Transforming Law and Governance (Aldershot, Hampshire: Ashgate, 2008) at 1 [Bosselmann], Voigt, supra note 50 at 3-4. Recall Chapter 4 and the Forest Stewardship Council as an example of transnational sustainability governance.

${ }_{55}$ United Nations Conference on Environment and Development, Rio Declaration on Environment and Development, UN Doc A/CONF.151/26 (vol I); 31 ILM 874 (1992), online: UN

<http://www.un.org/documents/ga/conf151/aconf15126-1annex 1.htm> Principles 1 and 4 [Rio].

${ }_{56}^{5}$ See, e.g., Resource Management Act 1991 (New Zealand) [RMA]; Sustainable Planning Act 2009 (Queensland, Aus); Sustainability Victoria Act 2005 (Victoria, Aus). In Canada: Federal Sustainable Development Act, SC 2008, c33 [FSDA]; Sustainable Development Act, The, CCSM c S270 (Manitoba); Sustainable Development Act, CQLR c D-8.1.1 (Quebec); Environmental Goals and Sustainable Prosperity Act, SNS 2007, c 7 (Nova Scotia). We will see that numerous statutes also include specific provisions on sustainable development. 
responsibility, ${ }^{57}$ and, as is often overlooked, is meant to operate at the individual level to change unsustainable patterns of consumption. ${ }^{58}$

The concept's potentially all-encompassing nature is both a strength and weakness. It is framed in terms that are difficult to reject. It is hard to imagine a country or corporation touting a commitment to unsustainable development. ${ }^{59}$ But at the same time, the fact that it is meant to cover everything means it risks saying nothing. ${ }^{60}$ Sustainable development has been described as "almost infinitely variable"61 and as an "essentially contested concept."62 Academic literature roughly categorizes sustainable development into "weak" and "strong" definitions. Weak sustainable development, as we will see, promises to integrate economic, social and environmental considerations, but without more endorses the status quo. Strong sustainable development has more radical potential for law and governance, ${ }^{63}$ but also fails to offer sufficient guidance to decision-makers.

Canada's Federal Sustainable Development Act ${ }^{6 t}$ is illustrative of weak sustainable development. It describes sustainable development as "based on an ecologically efficient use of natural, social and economic resources." ${ }^{55}$ It fails to acknowledge any possible conflict between economy, environment and social considerations. It currently authorizes a Plan for Responsible Resource Development that — far from critically evaluating the sustainability of current

\footnotetext{
${ }_{57}$ Wood et al, supra note 53 at 993-4.

${ }^{58}$ Susan Tirone, Karen Gallant, \& Katie Sykes, "Environmental Goals and Sustainable Prosperity Act And the People of the Province: EGSPA’s Social Deficit” (2012) 35 Dal L J 71.

${ }^{59}$ Lafferty, supra note 53185.

${ }^{60}$ Voigt, supra note 50 at 18.

${ }^{61}$ Sean Coyle \& Karen Morrow, The Philosophical Foundations of Environmental Law: Property, Rights and Nature (Oxford: Hart Publishing, 2004) at 203.

${ }^{62}$ Lafferty, supra note 53 at 186.

${ }^{63}$ Andrea Ross, "Modern Interpretations of Sustainable Development” (2009) 36 J L \& Soc'y 32 [Ross].

${ }^{64}$ FSDA, supra note 56.

${ }^{65}$ Ibid s 5.
} 
natural resource development in the country — whole-heartedly endorses the status quo. ${ }^{66}$ While the Plan commits to better monitoring and enforcement, it fails to address the forwardlooking aspect of sustainable development, which requires an assessment of whether the regulations and policies are themselves sustainable in the first place. ${ }^{67}$ It demonstrates what one commentator calls a "brownish" definition of sustainable development because it simply accentuates the environmental aspects of development decisions that the government is determined to take in any event. ${ }^{68}$

A common critique of weak definitions of sustainable development is that they are "illsuited to taking clear stances where there are tradeoffs between environmental, social and economic considerations, and to setting a few (instead of dozens of) strategic priorities for action." ${ }^{9}$ Critics argue that the idea that sustainable development requires decision-makers to integrate the three "pillars" of economy, equity and environment consistently plays out in favour of economy. ${ }^{70}$

The response comes from defenders of strong sustainable development, who prioritize the environment pillar of sustainable development. They ground their argument in the simple reality that the Earth has finite ecological thresholds; neither its natural resources nor is its

66 “Responsible Resource Development”, online: Government of Canada <http://actionplan.gc.ca/en/content/r2ddr2>.

${ }^{67}$ C Scott Findlay, et al., "Sustainability Lost: Comments on "Planning for a Sustainable Future: A Federal Sustainable Development Strategy for Canada" (2010) 22 JELP 77; David Boyd, "Sustainability Law: (R)Evolutionary Directions for the Future of Environmental Law" (2004) 14 Journal of Environmental Law and Practice 357 at 364-5 (emphasizing the forward-looking aspect of sustainable development).

68 Jorge E Viñuales, "The Rise and Fall of Sustainable Development" (2013) 22 RECIEL 3 at 6, 7 [Viñuales].

${ }^{69} \mathrm{Ibid}$. at 7; Bruce Pardy, "In Search of the Holy Grail of Environmental Law: A Rule to Solve the Problem" (2005) 1 McGill Int'l J Sust Dev L \& Pol'y 29 at 33 (sustainable development does not give us a clear roadmap for how to get to sustainability).

70 Viñuales, supra note 68 at 6; Ross, supra note 63 at 35; Wood et al, supra note 53 at 993. 
ability to assimilate the byproducts of development are unlimited. ${ }^{71}$ Defenders of the strong definition argue that integrated decision-making alone is not enough because it does not appreciate this ecological bottomline nor the ethical obligation owed to future generations to not push the Earth's ecological capacities to the limit. On this view, sustainable development is not ad hoc balancing between economic, social and environmental objectives. Instead, ecological sustainability provides the "normative core" of sustainable development such that economic prosperity and social justice can only take place above this ecological bottomline. ${ }^{72}$

The difficulty with this latter approach to sustainable development is that there is no set of uncontroversial ecological limits that can guide decision-making. There may be broad scientific consensus around some ecological thresholds — limiting global climate change to 2 degrees Celsius to prevent catastrophic effects, or the amount of remaining oil reserves, for example - but others will be unknown or fiercely contested. As we have seen throughout this thesis, there is no objective means for predicting these environmental limits. Added complexity arises when we attempt to determine how specific environmental decisions contribute to or undermine sustainability, which is also often far from clear. ${ }^{73}$

The result is that a strong definition seems to either require a prohibition on development in the face of ecological uncertainty (contrary to a plain reading of sustainable development); $7^{74}$ or, it dissolves into a potentially unconstrained balancing exercise. For example, the New Zealand Resource Management Act sets out a strong definition of sustainable

\footnotetext{
${ }^{71}$ Bosselmann, supra note 54 at 53; Ross, supra note 63 at 37-8; Voigt, supra note 50 at 38-46.

72 Bosselman, supra note 54 at 53.

${ }^{73}$ Hydroelectric or nuclear energy development are good examples here because they are often promoted as remedies to climate change.

${ }^{74} \mathrm{Eg}$. Bow Valley Naturalists Society v Canada (Minister of Canadian Heritage), [2001] 2 FC 461.
} 
management, to be applied to all administrative decision-making. ${ }^{75}$ However, interpretation of the definition has retreated from attempts to enforce an "environmental bottom-line" constraint on administrative decision-making toward an "overall judgment approach." 76 The latter raises the same concerns as weak definitions of sustainable development: there are seemingly no constraints on the ad hoc balancing that tends to favour continued development.

Despite these critiques of both the weak and strong definitions, we can see that sustainable development attempts to respond to features identified by the environmental emergency. It appropriately calls our attention to the fact that ecological systems have their own determinative, if unpredictable, processes that are not infinitely malleable. Its focus on integrated decision-making responds to the fact that we cannot reliably distinguish between benign regulatory decisions and those with the possibility of catastrophe. In addition, integration of economic, social and environmental considerations recognizes the limits of any one expert discourse in understanding regulatory problems and proposing solutions. Sustainable development also highlights the fact that those affected by regulatory decisions are not necessarily those in the here and now. Sustainable development emphasizes equity, regardless of geographic or temporal proximity to the particular regulatory decision or project. The challenge, then, is to show that these core elements of sustainable development can meaningfully guide decision-making without attracting the problems of the strong or weak definitions.

${ }^{75}$ RMA, supra note 56.

76 These cases are discussed in Bosselmann, supra note 54 at 64-66. See also: William Lahey \& Meinhard Doelle, "Negotiating the Interface of Environmental and Economic Governance: Nova Scotia's Environmental Goals and Sustainable Prosperity Act" (2012) 35 Dal L J 1 (on how the strong goals of Nova Scotia Act are implemented through further planning requirements making it difficult to assess whether the goals of actual sustainability are being met). 
A deliberative-democratic interpretation of sustainable development offers a way through the impasse of these competing conceptions of sustainable development. As we have just seen, both weak and strong versions of sustainable development focus on the three pillars of economy, environment and equity in decision-making. Weak sustainable development tends to sweep conflict under the rug in favour of economic interests. Strong sustainable development recognizes conflict, but in the absence of objective guidance, defaults to inevitable trade-offs between economic interests and environmental protection. In short, both versions focus entirely on the proper balance and distribution of environmental and economic benefits and harms.

Deliberative-democratic principles, in contrast, encourage us to understand sustainable development as a concept that recognizes individuals as responsible agents. They are not just passive recipients of environmental goods and harms, but active participants who are entitled to justification. ${ }^{77}$ Interpreting sustainable development in line with the deliberative-democratic ideals above, we must be prepared to reject certain reasons as impermissible because they are not, for example, reciprocal or general. Reciprocal reasons are those that are public-regarding (that is, they are not solely self-interested) and accessible to others. ${ }^{78}$ General reasons are those that address all who are similarly affected by a decision. ${ }^{79} \mathrm{~A}$ decision that excludes the consideration of future generations or far-away individuals who will nonetheless be impacted is not justified from this perspective.

\footnotetext{
77 Rainer Forst, The Right to Justification: Elements of a Constructivist Theory of Justice, translated by Jeffrey Flynn (New York: Columbia University Press, 2011) at 200 [Forst].

${ }^{78}$ Ibid. at 6; Amy Gutmann \& Dennis Thompson, Why Deliberative Democracy? (Princeton: Princeton University Press, 2004) at 4 [Gutmann \& Thompson].

${ }^{79}$ Forst, supra note 77 at 6.
} 
The very purpose of sustainable development is to acknowledge the decisional stakes for those who are not typically represented in the decision-making process. Thus, deliberativedemocratic principles require that decision-makers treat future generations and disadvantaged groups as "moral constituents," 80 even if they are not directly accountable to them in a democratic process. Indeed, deliberative democrats argue that deliberation promotes mutual respect and a greater sense of responsibility for collective decisions and their consequences. ${ }^{81} \mathrm{~A}$ deliberative-democratic interpretation is thus consistent with the promises of environmental stewardship and intergenerational equity that sustainable development has, thus far, struggled to instill in the institutions tasked with its implementation.

From this perspective, sustainable development further requires institutional conditions that promote deliberation. Those institutions with a sustainable development mandate must be justified on the basis that they promote deliberation. Collaborative forums designed to bring together a broad range of issues and interests might be justified on the basis that they further public deliberation in a way traditional hierarchical and siloed government bureaucracies cannot. ${ }^{82}$ Decision-makers with a mandate to promote "intergenerational solidarity" 83 might also be justified on the basis that they ensure the interests of future generations are addressed in the decision-making process. What is key in all cases is that both decisions and institutions operating under the banner of sustainable development are justified through public deliberation.

\footnotetext{
${ }^{80}$ Gutmann \& Thomspon, supra note 78 at 37-8; Forst, supra note 77 at 265.

81 Ibid. at 179.

${ }^{82}$ This point is made clearly in one of the last reports of Canada's National Round Table on The Environment and Economy, before it was defunded by the federal government in 2013. NRTEE was a direct response to WCED, supra note 49. It was an independent public policy advisory group that provided advice to the federal government on sustainable development policy: National Round Table on the Environment \& Public Policy Forum, Progress Through Process (Ottawa: Government of Canada, 2012).

${ }^{83}$ Imperial Oil v Quebec, 2003 SCC 58, [2003] 2 SCR 624 at para 19.
} 
Requiring actual deliberation over sustainable development decisions, avoids the dichotomy between naïve optimism and immediate trading-off posed by the strong and weak versions above. Because deliberation seeks a "rationally motivated consensus," ${ }^{44}$ participants engage in a wide-ranging and genuine search for alternative "win-win” scenarios. But it does not collapse into weak sustainable development if these do not exist. Instead it narrows in on issues that are genuine points of conflict and permits trade-offs only as a last resort. ${ }^{85}$

This emphasis on actual deliberation poses two potential problems however. First, actual deliberation is unlikely to generate consensus. Where deliberation leads to decisions that are substantively unjust - that is, they rest on reasons that are not reciprocal or general - the rule-of-law project requires appropriate institutional channels for contestation. ${ }^{86}$ Contestation enables other public institutions (conventionally the courts on judicial review) to require these decisions to be justified. Even still, publicly justified decisions typically have dissenters. As we have seen, deliberative democrats adopt a pragmatic stance that emphasizes the provisionality of deliberations. So long as future opportunities exist to revisit decisions and to seek reforms, a lack of consensus does not undermine the overall commitment to deliberative democracy.

We should expect, however, that the requirement of provisionality itself is subject to justification: i.e., some decisions will be more provisional than others. ${ }^{87}$ The context of

\footnotetext{
${ }^{84}$ Joshua Cohen, "Deliberation and Democratic Legitimacy" James Bonham, William Rehg eds, Deliberative Democracy: Essays on Reason and Politics (Cambridge, Mass: MIT Press, 1997) 67 at 75.

${ }^{85}$ Gutmann \& Thomspon, supra note 78 at 18; Henry S Richardson, Democratic Autonomy: Public Reasoning About the Ends of Policy (Oxford: Oxford University Press, 2002) at Chapter 15 [Richardson] (on how majority rule is a temporary closure device). For an example how sustainability assessment can help implement these kinds of practices see: Robert B Gibson, "Beyond the Pillars: Sustainability Assessment as a Framework for Effective Integration of Social, Economic and Ecological Considerations in Significant Decision-Making" (2006) 8 J of Envtl Assessment Pol'cy \& Mgmt 259.

86 See also Forst, supra note 77 at 182.

${ }^{87}$ Deliberative democrats argue that even long-settled norms cannot be fully insulated: Gutmann \& Thompson, supra note 78 at 54. But as Gutmann \& Thompson write: "We do not have to reargue the question of slavery every
} 
sustainable development suggests that provisionality should play a much more prominent role in an ongoing process of decision-making. Defenders of sustainable development emphasize its potential for instilling collaborative, dynamic and even experimental institutional design. ${ }^{88}$ Its core element of integration and its explicitly multi-jurisdictional scope suggests the need for multiple avenues for contesting development decisions at multiple scales. ${ }^{89}$ Moreover, within the decision-making institution itself we would expect mechanisms to promote ongoing deliberation over constantly changing information about the extent of environmental problems. ${ }^{90}$ As we saw in Chapter 5, democratic experimentalism is one attempt to institutionalize the deliberative-democratic principle of provisionality through a "rolling rule".

A second possible challenge comes from the complex nature of the problems to be deliberated. Cass Sunstein, a deliberative democrat, argues that regulatory issues are best addressed exclusively by experts through determinative methods of cost-benefit analysis. ${ }^{91}$ Unlike at the constitutional level where disagreement occurs over beliefs, he argues, regulating poses the problem of risk. Experts not laypersons, according to Sunstein, are in the best position to determine the best course of action in the face of these risks. He argues that the complexity of risk assessment exacerbates cognitive biases that lead laypersons to irrational

generation. But the justification for regarding such results as settled is that they have met the deliberative challenge in the past, and there is no reason to believe that they could not do so today." (Ibid. at 12-3) Sustainable development is at the far opposite end of the spectrum given the complexity and breadth of issues that it attempts to address and the accompanying debates about what it really means.

${ }_{88}$ Sustainable Development Law, supra note 50 at 231-4; Dryzek, supra note 50 at 161.

${ }^{89}$ In Canada, beyond the domestic court system, we have the Commissioner of the Environment and Sustainable Development: Online: Office of the Auditor General of Canada <http://www.oagbvg.gc.ca/internet/English/cesd_fs_e_921.html>. At the regional level, complaints can be brought before the Commission for Environmental Cooperation under Articles 14 and 15 of the North American Agreement on Environmental Cooperation, online: CEC <http://www.cec.org/ > . At the international level is the International Court of Justice. The leading decision on sustainable development is Case Concerning the Gabcikovo-Nagymaros Dam (Hungary v Slovakia), [1997] ICJ Rep 7.

${ }_{90}$ One example might be a petition mechanism that allows an individual to trigger an internal review of a decision at any future date provided that they compile and submit certain minimal preliminary evidence.

${ }^{91}$ Compare Cass R Sunstein, Designing Democracy: What Constitutions Do (Oxford: Oxford University Press, 2001) and Cass R Sunstein, Risk and Reason: Safety, Law, and the Environment (Cambridge: Cambridge University Press, 2002) [Risk and Reason]. 
decisions. ${ }^{92}$ Instead Sunstein argues for non-deliberative decision-making techniques, namely cost-benefit analysis. ${ }^{93}$ As we will now see, the precautionary principle responds to Sunstein's critique of a deliberative interpretation of sustainable development.

\section{B. The Precautionary Principle}

"where there are threats of serious or irreversible damage, lack of full scientific certainty shall not be used as a reason for postponing cost-effective measures to prevent environmental degradation. ${ }^{{ }^{*}}$

The precautionary principle is perhaps the most familiar and the most contested principle of environmental law. ${ }^{95}$ The principle originated in German environmental policy, but rose to prominence with its above articulation in the Rio Declaration on Environment and Development in 1992,96 and was rapidly taken up by domestic and international environmental laws in the decades that followed. Much like sustainable development, it is hard to disagree with the principle's sentiment, which is often described as "better safe than sorry." Precaution simply represents the idea that, when we are faced with potentially serious but uncertain threats, it is better to take early action to avoid such a worst-case scenario. What the principle requires of administrative decision-makers, as we will now see, is rather less clear.

The precautionary principle is well represented in Canadian environmental law. It can be found in the preambles of many federal environmental statutes and some provincial statutes,

\footnotetext{
${ }^{92}$ Sunstein is deeply pessimistic about non-expert perception of risk: Ibid. at 33-49, at 76 he writes: "Ordinary people do not show a richer rationality."

93 Ibid. at 106-7.

${ }_{94}$ Rio, supra note 55 Principle 15.

${ }_{95}$ Daniel Bodansky, "Deconstructing the Precautionary Principle" David D Caron, Harry N Scheiber eds, Bringing New Law to Ocean Waters (Leiden: Martinus Nijhoff Publishers, 2004) 381 at 381 (described as one the 10 commandments of international environmental law).

${ }_{96}$ Jacqueline Peel, The Precautionary Principle in Practice (Annandale NSW: The Federation Press, 2005) at 16 [Peel].
} 
and is a substantive provision in several federal statutes. ${ }^{97}$ These legislative statements are consistent with the Supreme Court's recognition that the precautionary principle is an emerging norm of customary international law ${ }^{98}$ and a federal guidance framework that identifies precaution a "legitimate and distinctive decision-making approach within risk management."99 Despite this clear evidence that precaution operates as a guiding principle in Canadian environmental law, there is a widespread sense amongst legal academics that it has yet to realize its potential. ${ }^{100}$

The principle's disappointing track record is partially due to confusion over its ambiguous administrative requirements. I will address this confusion in a moment. But I first contend that the principle is best understood as a deliberative-democratic response to the problem posed by Sunstein. Sunstein's argument, in short, is that experts are in the best position to make determinations about environmental risk through rational and comprehensive methodologies such as risk assessment and cost-benefit analysis. In contrast to these risk methodologies, Sunstein argues that the precautionary principle isolates particularly visible risks in the decision-making process for special treatment. ${ }^{101}$ To take one example, the LacMégantic disaster in Quebec might lead laypersons to "over-estimate" the risks of oil transport by rail. ${ }^{102}$ According to Sunstein, the precautionary principle encourages this kind of cognitive

\footnotetext{
${ }^{97}$ For example: CEAA, supra note 16 s 4; Species at Risk Act, SC 2002, c 29 ss 38, 41; Canadian Environmental Protection Act, 1999, SC 1999, c 33 ss 2, 6(1.1), 76.1; Pest Control Products Act, SC 2002, c 28 s 20 [PCPA]; Oceans Act, SC 1996, c 31 s 30.

${ }_{98} 114957$ Canada Ltée (Spraytech, Société d'arrosage) v. Hudson (Town), 2001 SCC 40, [2001] 2 SCR 241 at paras 302; Castonguay Blasting Ltd. v. Ontario (Environment), 2013 SCC 52, [2013] 3 SCR 323 at para 20.

${ }^{99}$ Privy Council Office of Canada, A Framework for the Application of Precaution in Science-Based Decision Making About Risk (Ottawa: Government of Canada, 2003) at 4.1 [Framework for Precaution].

${ }^{100}$ E.g. Chris Tollefson \& Jamie Thornback, "Litigating the Precautionary Principle in Domestic Courts" (2008) 19 Journal of Environmental Law and Practice 33 at 57 [Tollefson \& Thornback].

${ }^{101}$ Cass R Sunstein, Laws of Fear (Cambridge: Cambridge University Press, 2005) at [Laws of Fear].

102 On July 6, 2013, the breaks on a parked train failed, causing the train to speed downhill and derail in the centre of Lac-Mégantic, Quebec. The train, carrying over 6 million litres of bitumen, exploded killing 47 people and destroying much of the town. "Lac-Mégantic runaway train and derailment investigation summary" (2014), online:
} 
bias and provides a justification for decision-makers to act on misplaced public fears. In contrast, Sunstein argues that proper risk assessment corrects these biases by attending to risks on all sides of the equation. ${ }^{103}$ Once we acknowledge the full complement of risks, he argues the principle becomes incoherent and paralyzing because, taken literally, it "forbids all courses of action, including regulation.” 104

From a deliberative-democratic perspective, however, the objective of the precautionary principle is not to dictate any particular outcome. Rather it is to simply highlight the inherent limits in any expert analysis of future harm. ${ }^{105}$ Risk assessment may be able to adequately address gaps within existing scientific knowledge; ${ }^{106}$ but as we saw in Chapter 2, ecosystems are complex and adaptive systems characterized by unforeseeability and indeterminacy. This kind of complexity means that there are questions that no scientific methodology can feasibly answer. There are also questions we do not yet know to ask. Put differently, the precautionary principle identifies and corrects a different cognitive bias than the one Sunstein points out. Precaution ensures that "no evidence of harm" is not treated as equivalent to "no harm." The precautionary principle is not, as Sunstein argues, an (arbitrary) alternative to risk assessment. The principle addresses a fundamentally different question: what does a decision-maker do with a necessarily incomplete risk assessment in hand? ${ }^{107}$

Transportation Safety Board of Canada <http://www.tsb.gc.ca/eng/rapportsreports/rail/2013/r13d0054/r13do054-r-es.asp>.

${ }^{103}$ Lawes of Fear, supra note 101 at 58-9.

${ }^{104} \mathrm{Ibid}$. at 26.

${ }^{105}$ Peel, supra note 96 at Chapter 3.

${ }^{106}$ For example, a scientific gap arises when do not know whether a particular pollutant will interact with another to harm the environment. This is a gap "within" science because it is a question we know to ask and we may be able to approximate an answer through known scientific methodologies.

${ }^{107}$ Jaye Ellis, "Overexploitation of a Valuable Resource? New Literature on the Precautionary Principle" (2006) 17 European J of Int'l L 445 at 453 [Ellis]; Richardson, supra note 85 at $234 \mathrm{ff}$. 
Fundamentally the precautionary principle is an attempt to understand how public decisions can be justified in the absence of a solid factual foundation. ${ }^{108}$ This means that the "principle regulates the reasons for a decision and the process by which a decision is made....This is because regulating outcomes (beyond requiring decision makers to pursue broad statutory goals) is logically impossible in cases of scientific uncertainty." ${ }^{109}$ In practice this translates to a central preoccupation with the relationship between expert and non-expert views of scientific uncertainty. No precautionary principle proponent is anti-science; all seek sound environmental regulation that is based on the best understanding of the problem. Defenders of the principle, instead, are concerned with scientific hubris and the "actionorientation" of expert methodologies. ${ }^{110}$

A deliberative-democratic interpretation of the precautionary principle promises to open up these expert discourses to public scrutiny and input. Theories of deliberative democracy understand that expert decision-making is essential in any complex society. ${ }^{111}$ But in a deliberative system, expert decisions must reflect deliberative principles: i.e., they must be justified on the basis of reasons that those subject to the decision cannot reasonably reject.

\footnotetext{
${ }^{108}$ Elizabeth Fisher, "Review: Laws of Fear: Beyond the Precautionary Principle" (2006) Modern L Rev 288 at 289. ${ }^{109}$ Elizabeth Fisher \& Ronnie Harding, "The Precautionary Principle and Administrative Constitutionalism: The Development of Frameworks for Applying the Precautionary Principle" Elizabeth Fisher, Judith Jones, René von Schomberg eds, Implementing the Precautionary Principle: Perspectives and Prospects Edward Elgar Pub, 2006$) 113$ at 115 [Fisher \& Harding].

${ }^{110}$ Kerry H Whiteside, Precautionary Politics: Principle and Practice in Confronting Environmental Risk (Cambridge, Mass: MIT Press, 2006) at 126-8 [Whiteside]; Frank Fischer, "Environmental Regulation and Risk-Benefit Analysis: From Technical to Deliberative Policy Making" R Paehlke, D Torgerson eds, Managing Leviathan: Environmental Politics and the Administrative State 2d ed (Peterborough, Ont: Broadview Press, 2005) 59 at 67-8. See also Brian Wynne, "May the Sheep Safely Graze? A Reflexive View of the Expert-Lay Knowledge Divide" Scott Lash, Bronislaw Szerszynski, Brian Wynne eds, Risk, Environment and Modernity: Towards a New Ecology (London: SAGE Publications, 1998) 44 at 78 (on how the expert/layperson binary needs to be problematized) [Wynne]. ${ }^{111}$ John Parkinson \& Jane Mansbridge, Deliberative Systems: Deliberative Democracy at the Large Scale (Cambridge: Cambridge University Press, 2012) at 14-6 [Parkinson \& Mansbridge]; Gutmann \& Thompson, supra note 78 at 5; Richardson, supra note 85 at 222 (specifically on administrative agency expertise). In a more general sense a role for expertise in a deliberative democratic system has been articulated by Habermas as a two-track system, where conditions of ideal deliberation were only required for those core structures of a constitutional democracy: Jürgen Habermas, Between Facts and Norms (Cambridge: MIT Press, 1996) at 300.
} 
Deliberative democrats argue that the best way to ensure justified decisions is through representative and inclusive deliberative forums. These expose areas of uncertainty and encourage a broad search for agreeable alternatives rather than a narrow determination of "acceptable risk." 112 Kerry Whiteside argues that

"linking precaution to deliberative democracy is intended to imply that the processes that trigger and implement precautionary measures should include regularized forms of nonexpert citizen participation and collective judgment. The objective is to make citizen deliberation a formal part of the process, just as regulatory bodies systematically include scientific and economic advisers." 113

A deliberative interpretation of the precautionary principle cannot dictate specific public participation procedures in the abstract nor offer any universal reasons for preferring expert to non-expert views. But what it does offer is a renewed attention to the need for decision-makers to offer reasons for their decisions. This obligation to give reasons extends to the ultimate decision in which decision-makers must highlight points of uncertainty and how these were addressed. And it extends to procedural decisions that restrict the deliberative capacity of the decision-making forum. ${ }^{114}$ Through this obligation to justify decisions on terms which

112 Whiteside, supra note 110 at 57; Sheila Jasanoff, "A Living Legacy: The Precautionary Ideal in American Law" J A Tickner eds, Precaution: Environmental Science and Preventive Public Policy (Washington DC: Island Press, 2003) 227 at 237. See Dayna Scott for a nice analysis of precautionary decision-making in West Nile case and how it led to a broad search for alternatives: Dayna Nadine Scott, "When Precaution Points Two Ways: Confronting "West Nile Fever" (2005) 20 Can JL \& Soc 27. The emphasis on public participation is consistent throughout the precautionary principle literature: see also Peel, supra note 96; Fisher \& Harding, supra note 109; Genevieve Cartier, "Le principe de précaution et la déférence judiciare en droit administratif" (2002) 43 Les Cahiers de droit 79; Jamie Benidickson et al, Practicing Precaution and Adaptive Management: Legal, Institutional and Procedural Dimensions of Scientific Uncertainty Final Report (Ottawa: Institute of the Environment, University of Ottawa, 2005) [unpublished] at F 17 [Benidickson et al] .

${ }_{113}$ Whiteside, supra note 110 at 119 . Contrast this with a much narrower interpretation, that precaution should lead to greater margins of safety within expert analysis and that has nothing to do with public participation:

Daniel A Farber, "Probabilities Behaving Badly: Complexity Theory and Environmental Uncertainty" (2003) 37 UC Davis L Rev 145 at 168.

${ }^{114}$ Benidickson et al, supra note 112 at F21. 
individuals can both understand and reasonably accept, precaution in principle operates to rebuild trust between expert decision-makers and those who must live with the consequences of these expert decisions. ${ }^{115}$

We are now in a position to dispel two common misconceptions about the precautionary principle that persist in Canadian environmental law. The first misconception is that the precautionary principle compels the decision-maker to take a specific course of action; the second equates the precautionary principle with a reversed burden of proof.

The first misconception can be addressed and dismissed quickly. The Federal Court and Federal Court of Appeal repeatedly assert that the precautionary principle would have a "paralyzing effect" on development. ${ }^{116}$ As we have seen, this claim is not supported by the language in the Rio Declaration, any specific statutory expressions of the principle in Canadian environmental law, and least of all, by a deliberative interpretation of the principle. As a result, the Federal Courts have failed to seriously engage with the merits of the principle and its potential for informing administrative law requirements of reasonableness and fairness.

\footnotetext{
115 Trust is crucial to accounts of deliberative-democratic administrative decision-making: Fischer, supra note 110 at 71-2 (conflicting scientific expertise leads citizens to conduct their own socio-cultural analyses); Mansbridge \& Parkinson, supra note 111 . See Scott, supra note 112 for a rare positive example of trust in public decision-makers. ${ }_{116}$ Canadian Parks and Wilderness Society v. Canada (Minister of Canadian Heritage), 2003 FCA 197, [2003] FCJ 703 at para 24; Pembina Institute for Appropriate Development v Canada (Attorney General), 2008 FC 302, [2008] FCJ No 324 at para 32; Greenpeace Canada v Canada (Attorney General), 2014 FC 463, [2014] FCJ No 515 at para 83 [Greenpeace] (repeating the quote, although we will see in Part III that the Court in this case actually does properly apply the precautionary principle even if reluctant to name it as such). The idea that a "strong version" of precaution would compel the state to take action to eliminate risk persists in the precautionary principle literature more broadly. Goddard helpfully distinguishes between the precautionary principle and the principle of abstention, an impossible principle promoted by some environmental advocates that requires abstaining from all activities that could cause harm: Olivier Godard, "The Precautionary Principle and Catastrophism on Tenterhooks: Lessons From a Constitutional Reform in France" Elizabeth Fisher, Judith Jones, René von Schomberg eds, Implementing the Precautionary Principle: Perspectives and Prospects (Cheltenham, UK: Edward Elgar Pub, 2006) 63 at 65-6. The principle of abstention is vociferously promoted by many environmental non-governmental organizations in international environmental campaigns, which has given this 'strong' articulation of the principle some visibility: e.g. The Earth Charter, Principle 6, online: Earth <http://www.earthcharterinaction.org/content/pages/Read-the-Charter.html>.
} 
Accepting that the principle does not operate as a prohibition on development, environmental law scholars have sought an alternative interpretation in order to give the precautionary principle "some specific work to do." 117 Most Canadian legal academics have settled on the idea that the principle requires a reversal of the burden of proof. ${ }^{118}$ In their view, the principle requires that the proponents of potentially harmful activities demonstrate an absence of harm. This is supported by the substantive provisions of some environmental statutes that combine a statement of the precautionary principle with a requirement to reverse the burden of proof. ${ }^{119}$ However, this narrow interpretation of the principle seems to confuse the precautionary principle with a specific precautionary measure. ${ }^{120}$ It also reduces a principle that, at its best requires a deliberative process in which decision-makers exercise "complex judgment," 121 to a linear series of binary determinations (is there uncertainty about a threat [yes/no], can the proponent of risk rebut this assumption [yes/no], and so on). ${ }^{122}$

117 Tollefson \& Thornback, supra note 100 at 34.

118 This seems to be the default position on the precautionary principle in Canada: Ibid.; Benidickson et al, supra note 112; Nathalie Chalifour, "A (Pre) Cautionary Tale About the Kearl Oil Sands Decision: The Significance of Pembina Institute for Appropriate Development, et al. v. Canada (Attorney-General) for the Future of Environmental Assessment" (2009) 5 McGill Int'l J Sust Dev L \& Pol'y 251; David L VanderZwaag, "The Precautionary Principle in Environmental Law and Policy: Elusive Rhetoric and First Embraces" (1998) 8 JELP 355. As the precautionary principle lends itself to a variety of interpretations across a variety of regulatory contexts, there is support for the burden of proof interpretation in the international scholarship. Fisher documents some of this support in Elizabeth Fisher, Risk Regulation and Administrative Constitutionalism (Oxford and Portland OR: Hart Publishing, 2007) at Chapters 4 and 6 [Fisher].

${ }^{119}$ E.g. PCPA, supra note 97 s 7(6); Framework for Precaution, supra note 99 at 8 ("Overall, the responsibility for providing the sound scientific basis should rest with the party who is taking an action associated with a risk of serious harm....") But at the international scale the association between burden of proof and the principle is not as well founded: Ellis, supra note 107 at 459.

120 Unlike the criminal context, there is no universal burden of proof in administrative law. Statutory schemes impose a variety of different 'burdens' and 'standards' in the course of complex regulatory proceedings. This point is made by several academic defenders of precaution: Peel, supra note 96 at 155; Judith Jones \& Simon Bronitt, "The Burden and Standard of Proof in Environmental Regulation: the Precautionary Principle in an Australian Administrative Context" Elizabeth Fisher, Judith Jones eds, Implementing the Precautionary Principle: Perspectives and Prospects (Cheltenhem, UK: Edward Elgar Pub, 2006) 137; Fisher, supra note 118 at 44. Even in a quasi-judicial hearing, such as a pipeline approval hearing, the regulator in principle is not adjudicating between adversarial parties but is rather reaching a determination about the public interest after considering multi-faceted factors. 121 Whiteside, supra note 110 at 57.

122 This conflation between principle and measure has resulted in some bizarre jurisprudence in Australia where courts rely on scientific evidence to prove scientific uncertainty. If this threshold is not met, then the courts will 
A deliberative interpretation of the precautionary principle would lead to a variety of institutional arrangements, many of which would have no relationship to a juridical burden-ofproof approach. At a very basic level, the precautionary principle requires transparency about potential risks to allow the public to scrutinize and contest risk assumptions made by administrative decision-makers. ${ }^{123}$ Formalized mechanisms of public participation, required by the principle, could include public notice-and-comment periods, ${ }^{124}$ active intervenor status in assessment processes or negotiated regulation-making, ${ }^{125}$ or in especially high stakes instances, perhaps even a citizens' assembly working in concert with an expert body. ${ }^{126}$ Precaution might even require wholly separate institutions, such as public watchdogs or auditors, which work alongside expert regulators and subject their decisions to expert peer review. ${ }^{127}$ It is difficult to see how any of these innovations could be generated from a narrow requirement on decisionmakers to reverse the burden of proof.

fall back on an inchoate notion of "caution" as opposed to the more rigorous requirement of precaution that would result in a reversed burden of proof: Telstra Corp Ltd v Hornsby Shire Council, [2006] NSWLEC 285 [Telstra]; Douglas E Fisher, Australian Environmental Law: Norms, Principles and Rules 3d ed, (Pyrmont, N.S.W: Thomson Reuters, 2014) at 7.60. For an interesting analysis of how Telstra is an attempt to reconcile two visions of administrative constitutionalism, see: Fisher, supra note 118 at 154-160. In Canada, the dominant judicial approach seems to be that the precautionary principle is one factor to be considered e.g.: Sierra Club Canada v Ontario (Ministry of Natural Resources), 2011 ONSC 4655, [2011] OJ No 4373; Lake Waseosa Ratepayers' Association v Pieper, 2008 CLB 1707, [2008] OJ No 728; Western Canada Wilderness Committee v British Columbia (Ministry of Forests, South Island Forest District), 2003 BCCA 403, [2003] BCJ No 1581. It is therefore understandable that Tollefson, \& Thornback, supra note 100 view the Telstra approach as an improvement.

${ }^{123}$ Whiteside, supra note 110 at 135-6. The PCPA, supra note 97 allows individuals to trigger a review of regulations and products in light of new information. The Court has interpreted this provision fairly generously: Weir v Canada (Minister of Health), 2011 FC 1322.

${ }^{124}$ David Dyzenhaus, "Law as Justification: Etienne Mureinik's Conception of Legal Culture" (1998) 14 S Afr J on Hum Rts 11 at 35.

125 Richardson, supra note 85 at $220-222$.

${ }^{126}$ Cartier, supra note 112 at 99-100 (observing that citizen assemblies are the norm in Europe).

127 Well-orchestrated and timely campaigns by trusted institutions might be able to pre-empt or mitigate polarization on controversial topics. See: Whiteside, supra note 110 at 133 on parliamentary commissions or permanent advisory bodies fulfilling this role. 
The deliberative interpretation of precaution is not without its own challenges. Taken seriously, a deliberative interpretation undermines defenders' attempts to limit the principle's application to issues that may have serious or irreversible impacts. ${ }^{128}$ If the precautionary principle is best understood as an extension of deliberative democratic theory, there is no reason to limit the principle's impact to special cases. Recall the goal of deliberative democracy is a system of governance in which free and equal citizens actively participate in decisionmaking processes. Furthermore, the concept of the environmental emergency emphasizes our inability to reliably determine in advance which issues contain the possibility of environmental catastrophe. Indeed, the principle might be most beneficial in situations that do not, at first glance, seem to meet its threshold requirement. ${ }^{129}$

The answer again lies in rejecting the tendency to view the precautionary principle in black-and-white, all-or-nothing terms. The theory of the administrative state that underpins the precautionary principle-that is an administrative state governed by a democratic conception of the rule of law-is always at work. Public decision-makers must always strive to fulfill this aspiration. But when decision-makers are faced with novel issues, novel risks, or the foreseeable chance of a catastrophe, the precautionary principle operates to strengthen these public-justification requirements. ${ }^{130}$ Precaution, in other words, demands more intensive

\footnotetext{
128 This seems to be the one of the few points of consensus amongst all defenders of precaution: it only applies to specific environmental decisions. Tollefson \& Thornback, supra note 100 at 55 (defending Telstra against Peel's critiques); Peel, supra note at 96 at 221 (critiquing the using of the threshold test, but retaining it in her own defence of the principle); Whiteside, supra note 110 at 123; Laws of Fear, supra note 101 at 114 (defending an "AntiCatastrophe Principle”).

129 See, e.g., Brian Wynne, "Uncertainty and Environmental Learning" (1992) 2 Global Environmental Change 111 at 118; Daniel Bodansky, "Scientific Uncertainty and the Precautionary Principle" (1991) 33 Environment: Science and Policy for Sustainable Development 4 at 43.

130 Jean-Pierre Dupuy, “Complexity and Uncertainty A Prudential Approach to Nanotechnology” in Health and Consumer Protection Directorate General of the European Commission, Nanotechnologies: A Preliminary Risk Analysis on the Basis of a Workshop Organized in Brussels on 1-2 March 2004 (European Commission, 2004$) 71$ at 82 (arguing that precaution reveals we are stuck in a regulatory paradox in which we are under a constant obligation to attempt to anticipate the consequences of our actions, even though it is impossible to do so).
} 
procedures that enable thorough deliberation. It demands more comprehensive reasons detailing sources of uncertainty and how the decision-maker accounted for these. And it demands closer scrutiny of these justifications to ensure that potentially catastrophic decisions have been made in accordance with democratic principles and the rule of law.

\section{Fairness and Reasonableness in Environmental Law}

I have argued that the environmental principles of sustainable development and precaution should be interpreted in line with the ideals of deliberative democracy. This interpretation allows us to narrow in on some more specific requirements of these expansive principles. In particular, we have seen that deliberative-democratic theory requires that institutions tasked with sustainable development objectives must be publicly justified, that is, they must operate in a way that promotes deliberation either locally (within the institution), systemically (in other democratic institutions), or both. The deliberative interpretation of sustainable development further requires decision-makers to attend to the interests of future generations or disadvantaged groups who will be affected regardless of their geographic location. Both sustainable development and precaution require formalized mechanisms for public participation to counter expert discourses. Precaution emphasizes the importance of this requirement where there is uncertainty about the threat of a catastrophe. Taken together, these requirements safeguard the autonomy of individuals - their capacity as rational and selfdetermining agents - even in complex decision-making contexts such as environmental decision-making. 
The effect of these environmental principles therefore is to inform common law requirements of reasonableness and fairness. ${ }^{131}$ Sustainable development and precaution are not empty platitudes (“proceed with caution”), restatements of the status quo, or additional factors for a decision-maker to take into account. Rather they inform the rule-of-law project in environmental law, a project in which legal subjects are active participants in the construction and maintenance of their system of governance. Public decisions, therefore, must be publicly justified on the basis that they uphold this status.

I have not offered a definitive account of either sustainable development or precaution. Both principles are invoked across a diverse and wide range of regulatory contexts. Specific statutory requirements, the nature of the particular regulatory problem, and actual deliberations amongst participants will all shape the specific requirements of these principles in any given instance. As we will see in a moment, the principles are part of the NEB's regulatory framework and therefore impose particular deliberative and justificatory requirements on the NEB.

The foregoing interpretation of sustainable development and precaution raises a prior question, however, about whether the existing institutional arrangements for assessing major pipelines could be publicly justified. It is not clear that they could be. As we will see in the next part, there are severe limitations within the existing NEB process that undermine any claim

\footnotetext{
${ }^{131}$ For an argument that the precautionary principle is an independent element of reasonableness, even in the absence of a statutory statement of the principle, see Cartier, supra note 112. Understanding environmental principles in this way helps respond to Thomas Poole's critique of Dyzenhaus' articulation of common law constitutionalism. Poole argues that common law principles are too "soft-edged" or malleable to provide any sort of blueprint for decision-makers: Thomas Poole, "Constitutional Exceptionalism and the Common Law" (2009) 7 Int'l J Const L 247 at 263-8. As we saw in the previous chapter, Dyzenhaus does not claim to offer a blueprint. Rather, he offers core principles that are necessarily informed by their context. The normative context includes principles of sustainable development and precaution that provide a measure of sharpness to these allegedly amorphous principles.
} 
that it complies with the rule-of-law requirement of public justification. At the very least, it is easy to imagine institutional reforms that would better fulfill the deliberative ideals of sustainable development and precaution. The dramatic expansion of Alberta oil sands development facilitated by transcontinental pipelines ought to have been addressed directly, rather than disjointedly and belatedly during individual pipeline proposal hearings. ${ }^{132}$ We could imagine a comprehensive process in which the full socio-ecological effects of oil sands development are assessed directly through known methods of sustainability assessment. ${ }^{133}$ Instead of beginning with an assumption about the economic benefits of oil sands development such an assessment might ask the prior questions of: "How have we reached the conclusion that the tar [oil] sands create wealth? What kind of wealth? Wealth for whom?"134 A citizens' assembly might then deliberate on the results of the assessment attending to both known and speculative sources of uncertainty. After hearing expert testimony, they might propose a range of conditions under which development would be acceptable and offer recommendations to Cabinet or the NEB that would then be responsible for giving effect to those conditions when specific projects are proposed.

This of course would require the legislature to take the lead in upholding the rule-oflaw project. In certain political climates this might appear to be an exercise of wishful thinking. But these reforms draw from prior experience. Sustainability assessment and broad public participation were central to the environmental assessment of the proposed Mackenzie Valley

\footnotetext{
${ }^{132}$ I am far from the first to suggest this obvious failing in the oil sands regulatory process. See, e.g., Woolley, supra note 48 at 181-2.

133 Gibson, supra note 85.

${ }^{134}$ Heather McLeod-Kilmurray \& G Smith, "Unsustainable Development in Canada: Environmental Assessment, Cost-Benefit Analysis, and Environmental Justice in the Tar Sands" (2010) 21 JELP 65 at 67.
} 
Pipeline. ${ }^{135}$ British Columbia relied on a citizens' assembly for electoral reform; ${ }^{136}$ a similar model was proposed for Australian climate change reform. ${ }^{137}$ Ontario's impressive reform efforts to protect its sources of drinking water are founded on local land use planning that combines public deliberation and scientific expertise. ${ }^{138}$ All of these examples come much closer to fulfilling rule-of-law aspirations than the existing regulatory scheme. The fact that they have been implemented in the past suggests that they can be implemented again and hopefully better as we learn from prior experience.

Though the existing regulatory process for approving pipelines falls far short of this ideal, understanding the rule of law as a requirement of public justification means that institutions must continue to strive to uphold the rule-of-law project within their own institutional constraints. We will now see that public justification demands much more from the NEB.

\section{Part III. Publicly Justifying the Pipelines}

To summarize the above two parts, the NEB is governed by the $C E A A$, the $N E B A$ and core common law principles of fairness and reasonableness. The $C E A A$ explicitly directs the

\footnotetext{
135 Joint Review Panel for the Mackenzie Gas Project (2005), online CEAA <http://www.ceaa.gc.ca/default.asp?lang=En\&xml=99CDFBEE-2F6F-49BF-99C9-38AB1FF8C281>.

Discussion about the desirability of this pipeline has been ongoing for a significant period of time: Thomas $\mathrm{R}$ Berger, Northern Frontier, Northern Homeland: The Report of the Mackenzie Valley Pipeline Inquiry, Vol 1 (Ottawa: Supply and Services Canada, 1977).

${ }_{136}$ Mark E Warren \& Hilary Pearse, Designing Deliberative Democracy: The British Columbia Citizens' Assembly (Cambridge: Cambridge University Press, 2008).

137 "PM dumps citizens' assembly on climate change" (7 October 2010) The Australian, online: The Australian <http://www.theaustralian.com.au/national-affairs/climate/pm-dumps-citizens-assembly-on-climatechange/story-e6frg6xf-1225935582575>.

${ }^{138}$ See Ontario Source Protection Overview, online: Ontario Government <https://www.ontario.ca/environmentand-energy/source-protection>. Patricia Hania, "Climate Change and the Protection of Drinking Water in Ontario: An Opportunity to Adopt Adaptive Management?” (2011) 22 JELP 167.
} 
NEB to "promote sustainable development in order to achieve or maintain a healthy environment and a healthy economy" 139 and dictates that it "must exercise [its] powers in a manner that protects the environment... and appl[y] the precautionary principle." ${ }^{440}$ The NEB is also subject to the Federal Sustainable Development Act and, by virtue of its combined mandate to consider economic, social and environmental impacts of proposed pipelines, reflects sustainable development's central element of integrated decision-making. ${ }^{141}$ The statutory provisions on sustainable development and precaution do not impose specific requirements on the NEB. This means that the deliberative-democratic interpretation of these principles should prevail. In the absence of unambiguous statutory language to the contrary, these principles operate to inform common law requirements of fairness and reasonableness that govern the NEB's assessment process. In short, for the NEB to act with legal authority it must publicly justify its decisions on the basis of reasonableness and fairness, understood in light of sustainable development and precaution.

At this juncture it is important to recall the central argument of Chapter 5 that it may not be the court that is in the best position to make some or all of these determinations. Some other form of public institution may be necessary, though for ease of reference I will refer to

\footnotetext{
${ }^{139}$ CEAA, supra note $16 \mathrm{~s} 4(1)(\mathrm{h})$. At s 2, the Act further adopts the language from WCED, supra note 49, not the weaker version from the $F S D A$, supra note 56 .

${ }_{140}$ Ibid. s4(2).

${ }^{141}$ Sustainable development and precaution only feature in the Northern Gateway Pipeline JRP; they are absent in all other NEB decisions. In the JRP Report, the panel notes that sustainable development informed its approach to the design of public hearings: Considerations, supra note 30 at 4. The Report also states that the JRP took a precautionary approach: Ibid. at 5. However, as becomes clear in later in the Report, the JRP uses the phrase "precautionary approach" rather indiscriminately. It is most frequently used to describe how Enbridge has proposed to construct and operate the pipeline and terminal, rather than the regulatory process for evaluating Enbridge's claims. See, especially, ibid. at 147 and 168 (referring to Enbridge's precautionary approach to reduce the likelihood of a marine spill to as low as reasonably practicable).
} 
this reviewing body as a court, since judicial review is at present the only review mechanism available. ${ }^{142}$

I take up each of the issues identified in Part I that go to the fairness, reasonableness and independence of the NEB's assessment and recommendation. This division between fairness, reasonableness and independence, however, is somewhat artificial. The fairness of the process is only meaningful if it includes the possibility of influencing the substantive outcome. Moreover, procedural choices require justification by the decision-maker. And, particularly in complex regulatory cases, what counts as a reasonable decision will depend in large measure on the processes relied on to arrive at that determination. ${ }^{143}$ This part ends with a consideration of the NEB's independence as this provides a convenient lens through which to address two broader issues: the intensity of scrutiny by the court, and what happens when statutory language clearly purports to exempt the decision-maker from the rule-of-law project.

\section{A. Fairness}

In the first part of this chapter, I identified two specific issues with respect to the NEB's process for assessing the public proposals: its denial of an oral hearing and oral crossexamination of the proponent's application, and its restrictive interpretation of the standing requirement for members of the public to participate in the assessment. I now argue that the

${ }^{142}$ NEBA, supra note $14 \mathrm{~s} \mathrm{22(4).} \mathrm{There} \mathrm{is} \mathrm{no} \mathrm{statutory} \mathrm{appeal} \mathrm{mechanism} \mathrm{for} \mathrm{approval} \mathrm{recommendations} \mathrm{of} \mathrm{the}$ NEB. The only review is judicial review to the Federal Court of Appeal. Though it is not clear at present that there would be any difference in judicial scrutiny that would result from a statutory appeal vs judicial review: McLean v British Columbia (Securities Commission), 2013 SCC 67, [2013] 3 SCR 895.

${ }^{143}$ Richardson, supra note 85 at 228 (The very fact that we need experts to help make decisions means that trust cannot be fully based on their reliability. We therefore must trust the way they make decisions.); Wynne, supra note 110 at 57 (arguing that risk perception is primarily relational; that is based on the perceived trustworthiness of the expert institutions tasked with controlling the risk); Lisa Heinzerling, "Pragmatists and Environmentalists" (2000) 113 Harv L Rev 1421 at 1444 (emphasizing the significance of the context of environmental decisionmaking, and particular, whether decisions are made under conditions of trust). 
NEB has failed to justify these decisions by offering reasons that adequately reflect the common law principles of fairness and reasonableness.

\section{i. Written Hearing}

The first issue is whether the NEB has adequately justified its decision to hold a predominantly written hearing. Recall from Part I that the "hearing" for the pipeline approval proceeds on the basis of the proponent's detailed written application for approval. The NEB's assessment of that application takes place through an exchange of written correspondence between the Board members, intervenors and the proponent. This written correspondence contains requests to the proponent to submit more information, conflicting evidence by intervenors, or information about how interested parties will be affected by a pipeline approval. Intervenors unsuccessfully challenged the Trans Mountain Hearing Order, which denied them any opportunity to orally cross-examine the proponent on the project proposal. ${ }^{144}$ The Hearing Order also restricted oral argument to a few days of closing argument after the NEB had issued its draft conditions that would apply in the event of an approval. Intervenors argued the process denied any meaningful opportunity to debate whether the pipeline should be approved in the first place. The NEB held that the process satisfied the requirements of procedural fairness. It reasoned that it does not conduct "a criminal or civil trial" but rather "a process for gathering and testing evidence for the Board's preparation, as an expert tribunal, of its recommendation" of whether the proposal is in the public interest. ${ }^{145}$

\footnotetext{
${ }_{144}$ Notices of motion from Ms Robyn Allan and Ms Elizabeth May to include cross-examination of witnesses (7 May 2014),OH-O01-2014 Ruling No 14 [Trans Mountain], online: NEB <https://docs.neb-one.gc.ca/> [TMX CrossExam Ruling].

145 Ibid. at 4.
} 
As noted, the requirement of procedural fairness owed by the Board is not informed by the criminal or civil trial context. Instead it is informed by a deliberative interpretation of the principles of sustainable development and precaution. The Board must therefore justify its decision to withhold cross-examination on the basis that it adequately supports the deliberative capacity of the NEB and the public writ large. This flows from a purposive understanding of the Board's role, which it correctly identified in its reasons, quoted above. Its dual role is to form an expert opinion on whether pipeline development is in the public interest and to support a democratically accountable decision-maker, Cabinet, in making an informed decision.

The decision to deny oral cross-examination seems to impair the NEB's ability to carry out this dual role, giving rise to questions about whether this decision could be justified. The lack of oral cross-examination risks undermining the deliberative capacity of the NEB in reaching its expert recommendation. ${ }^{146}$ Intervenor scrutiny is the primary mechanism on which the NEB relies for testing the proponent's information. Board members, of course, exercise their own expertise. But participant input vastly expands the range of views put to the Board. Intervenor participation provides a significant counterweight to the fact that all the information for the project proposal is in the proponent's hands. The Board reasoned that two rounds of written information requests to the proponent is an adequate replacement to oral cross-examination. However this claim is plainly unsupported. It does not answer to prior experience with written requests for additional information in which proponents have repeatedly failed to answer the requests. ${ }^{147}$

\footnotetext{
${ }^{146}$ In this sense, the expert role of the NEB is distinct from the expert evidence that is adduced by the proponent or intervenors. The NEB possesses "evaluative expertise": Richardson, supra note 85 at 225. Jasanoff focuses on this kind of expertise - what she calls "regulatory science" - in Sheila Jasanoff, The Fifth Branch: Science Advisors as Policymakers (Cambridge, Mass: Harvard University Press, 1990) at 230.

${ }_{147}$ Supra, note 38.
} 
The decision to hold a written hearing also risks impairing the NEB's additional deliberative functions. The direction of the NEB's recommendation is immediately to the Cabinet, the ultimate decision-maker under the NEBA. But, as we saw in the previous chapter, the direction of the reasons is also to those who are affected by the decision. The specific structure of the NEB's governing legislation is to promote democratic accountability; that is, to enable the public to hold elected officials to account for major development decisions. Put differently, the NEB's mandate is necessarily a deliberative one in the sense that its recommendations enable further deliberation by both the Cabinet and public about the desirability of pipeline development.

From this perspective a written hearing is highly problematic. Important exchanges between Board members, intervenors and the project proponent are filtered through technical documents and take place largely out of public view. Where an oral hearing crystallizes key issues for participants, the Board and the public, a written hearing is conducted through thousands of online documents. Any defensible justification for the elimination of oral crossexamination must therefore account for its negative impact on public deliberation. ${ }^{148}$

The NEB supports this decision by pointing to its legislative mandate which prioritizes timeliness over fairness. ${ }^{149}$ The statutory constraints are real, but they do not clearly and unambiguously exclude common law requirements of procedural fairness. While the NEBA

\footnotetext{
${ }^{148}$ In the instance of Line 9, it is the only public process because this project did not require Cabinet approval. The federal Cabinet does not undertake a separate public consultation process after receiving the NEB's recommendation. CEAA, supra note 16 s 31(1) and NEBA, supra note 14 s 54(2) require Cabinet to issue reasons for its decision. But these reasons are typically cursory and rely exclusively on the findings in the recommendation report.

${ }_{149}$ TMX Cross-Exam Ruling, supra note 144 at 4.
} 
does impose a 15-month deadline on the NEB, it also allows the NEB to request extensions. ${ }^{150}$ A major pipeline proposal with over 400 intervenors and 1,000 applications to participate is precisely the kind of case in which a Board ought to request such an extension. Of course, it may be denied an extension by an executive set on pipeline approvals. But that is beside the point. An NEB committed to public justification will have fulfilled its rule-of-law obligations by making it clear that the executive is choosing to act without the full benefit of the NEB's expertise and public process.

Nor do prudential considerations that typically factor into procedural decisions arise in this case. This is not a situation in which the administrative decision-maker will be faced with the prospect of conducting hundreds or thousands of individual oral hearings that would cripple the administrative process. ${ }^{151}$ These are significant one-time approvals with effects that will extend to the public at large and well into the future. While the NEB has a broad mandate and a demanding regulatory workload, reaching a determination on whether a handful of major development projects are in the public interest is a central aspect of its mandate. As the NEB observes, it is an expert on its own process; it can surely canvass creative alternatives for conducting an oral hearing within the legislated time limits. ${ }^{152}$ At the very least, it ought to ask which participants would actually want to actively intervene in an oral hearing, which is likely only a subset of those who applied to participate. One could imagine further grouping

\footnotetext{
150 NEBA, supra note 14 s52(7). The Minister can grant up to 3 months; Cabinet can grant an extension of any duration.

${ }^{151}$ This is typically an argument against requiring oral hearings. See: Grant Huscroft, "From Natural Justice to Fairness: Thresholds, Content, and the Role of Judicial Review" In Colleen Flood, Lorne Sossin eds, Administrative Law in Context 2d ed (Toronto: Emond Montgomery Publications Ltd, 2012) 147 at 173.

${ }_{152}$ Past practice for the environmental assessment of major project proposals has been to hold public hearings in the municipalities affected by the proposal. This was the format followed by the Northern Gateway Pipeline JRP.
} 
intervenors by issue, and identifying particular contentious issues to prioritize for an oral hearing. ${ }^{153}$

The question of whether there is a defensible justification for the current NEB process remains open. Perhaps there is. But such a justification must be consistent with a requirement of fairness that enables deliberation by both the $\mathrm{NEB}$, in forming its recommendation, and the public, in holding the ultimate decision-maker to account.

\section{ii. Restricted Public Participation}

A deliberative interpretation of sustainable development and precaution also has important implications for public participation. The pipelines, if approved, will have long-term consequences. They create a literal path dependence, which we are now seeing in the current hearings where existing pipelines are used as justifications for further development. ${ }^{154}$ They also entrench Canada's commitment to developing the controversial Alberta oil sands. Fairness, in this context, requires that the NEB specifically justify shutting members of the public out of its process.

The NEBA does constrain this common law requirement. It states that

"the Board shall consider the representations of any person who, in the Board's opinion, is directly affected by the granting or refusing of the application, and it may consider

\footnotetext{
153 The NEB already operates with process advisors that facilitate participation in the hearings. These coordinators could be utilized to restructure the hearing. See, e.g., "Energy East Process", online: NEB <https://www.neb-one.gc.ca/pplctnflng/mjrpp/nrgyst/index-eng.html>.

${ }^{154}$ See, e.g., Line 9 Decision, supra note 15 at 67; Line 9 Participation, supra note 23 at 10 (on how the fact of existing pipelines should reduce administrative requirements).
} 
the representations of any person who, in its opinion, has relevant information or expertise.” 155

The NEB has interpreted this provision to restrict public participation. It has held that the "directly affected" language of the statute evinces a legislative intention to exclude participants who have a "general public interest." 156 It has also rejected the "public interest standing" test that is used for constitutional law. ${ }^{157}$ It stated that "to be directly, affected, the Board considers whether a person has shown a specific and detailed interest, as well as a sufficient direct project impact on the interest." ${ }^{158}$ On the application of the "relevant expertise or information" standard, the $\mathrm{NEB}$ at times seems to take a generous approach, by allowing parties the opportunity to provide a letter of comment. But the Board repeatedly asserts that it - the Board - is the expert and possesses the relevant expertise for assessing the concerns raised by would-be participants. In other words, it relies on its own claim to technical expertise as a reason to deny standing. ${ }^{159}$

The Board has also held that neither s.2(b) or s.7 of the Charter guarantees a public right to participation in the hearing process. The Board reasoned that its procedural decision "revolves around a right to participate in the Board's process, not the exercise of a fundamental freedom [of speech]." 160 Jilted participants can -and do-express themselves in other public forums. The Board further reasoned that "[q] uasi-judicial tribunals like the Board invariably establish expression-limiting rules of procedure, relevance, and decorum." ${ }^{161}$ The Board has denied the s.7 claim on the basis that a deprivation of life, liberty or security of the person has

\footnotetext{
155 NEBA, supra note 14 s 55.2.

156 See Line 9 Participation, supra note 23 at 7.

${ }^{157} \mathrm{Ibid}$. at 10-11 (rejecting intervenor status for certain public interest groups).

158 TMX Participation, supra note 23 at 5.

${ }^{159}$ Line 9 Participation, supra note 23 at 11-12.

${ }_{160}$ TMX Section 2 Ruling, supra note 26 at 8.

${ }^{161} \mathrm{Ibid}$. at 10.
} 
not been “'proven to result' from the Board's List of Issues decision or from its Ruling on Participation." 162 The Federal Court has deferred to the Board on these matters, stating that "Board hearings are not an open-line radio show where anyone can dial in and participate."163

From the perspective of public justification, however, none of these reasons can stand. While the "directly affected" language may preclude a general right to public participation, it is not clear why a person must be affected differently or more severely than the "mere" general public to count as directly affected. ${ }^{164}$ At the very least, the NEB would have to justify its decision to import additional requirements into the statute. It is not clear this decision could be justified in light of the relevant environmental principles. In addition, a proper interpretation of sustainable development imposes positive obligations on the NEB to ensure that particular interests - those of future generations and disadvantaged groups - are represented in their process. While the NEB does undertake special efforts to include Aboriginal groups, ${ }^{165}$ it does not make a point of ensuring that its hearings are otherwise representative.

Importantly, the NEBA does not unambiguously eliminate public participation because it gives the NEB discretion to hear from those with "relevant expertise or information." This language could easily be interpreted by the NEB as statutory authority for implementing an

162 TMX Section 7 Ruling, supra note 27 at 2.

163 Sinclair, supra note 24 at para 76.

${ }^{164}$ For a somewhat more promising line of authority, see the Alberta Court of Appeal's recent decisions: Kelly $v$ Alberta (Energy Resources Conservation Board), 2009 ABCA 349; Kelly v Alberta (Energy Resources Conservation Board), 2011 ABCA 325; Kelly v Alberta (Energy Resources Conservation Board), 2012 ABCA 19.

165 The Crown also owes a constitutional duty to consult with aboriginal peoples that is independent of the NEB's statutory authority: Rio Tinto Alcan Inc v Carrier Sekani Tribal Council, 2010 SCC 43, [2010] 2 SCR 650. The adequacy its consultation in the Northern Gateway Pipeline process is currently before the Federal Court of Appeal. A significant development is the claim by numerous aboriginal groups to indigenous legal authority: Gordon Christie, "Indigenous Authority, Canadian Law, and Pipeline Proposals" (2013) 25 JELP 189. 
open notice-and-comment period. ${ }^{166}$ And this interpretation would be justified on the basis that both sustainable development and precaution emphasize the need for inclusive and formalized public processes in environmental decision-making. ${ }^{167}$ While the Board may not be "an openline radio show," it is the only public process that precedes a major regulatory decision.

The Board's repeated assertion that it is the expert is not an adequate justification for excluding an applicant to participate. As we have seen, both sustainable development and precaution destabilize any claims to authoritative scientific or economic expertise. It follows that the NEB's decision to exclude certain applicants on the grounds they do not possess relevant expertise or information cannot be justified by virtue of the NEB's monopoly on expertise. It is still possible that the NEB could justify its exclusion of certain applicants in a way that is consistent with the common law requirement of fairness. But even prudential reasons are unpersuasive. At present, it seems that denying interested participants status in the hearings is proving more onerous than allowing a general notice-and-comment period. It requires the $\mathrm{NEB}$ to conduct a two-stage process for participation, rather than a one-stage process that considers the applicants' comments on their merits. ${ }^{168}$

Notice that the requirement on the NEB to publicly justify its decisions on the basis of common law requirements means that the alleged Charter violations do not arise. On this understanding of the rule of law there is a fundamental connection between constitutional and

\footnotetext{
166 Admittedly, this is a bit of a stretch given that the CEAA seems to carve out the NEB process as an exception: CEAA, supra note $16 \mathrm{~s} \mathrm{19(1)} \mathrm{("The} \mathrm{environmental} \mathrm{assessment} \mathrm{of} \mathrm{a} \mathrm{designated} \mathrm{project} \mathrm{must} \mathrm{take} \mathrm{into} \mathrm{account} \mathrm{the}$ following factors:....(c) comments from the public — or, with respect to a designated project [governed by s54 of the NEBA], any interested party...”).

${ }^{167}$ On the role of notice-and-comment periods in promoting agency deliberation in the United States see: Mark Seidenfeld, "The Role of Politics in a Deliberative Model of the Administrative State" (2013) 81 George Washington Law Review 1397. For an argument that notice-and-comment is insufficient to ensure democratic autonomy see: Richardson, supra note 85 at 220-1.

168 The NEB (as it is quick to note) already grants the vast majority of applications to participate and most participants only submit a letter of comment.
} 
administrative law. "The Charter is not an intrusion into the Canadian legal order. Rather, it is a much more explicit and novel statement of fundamental values, so it represents continuity rather than radical change." 169 Administrative decisions that comply with the requirement of public justification are those that also reflect basic constitutional rights in a liberal democracy. ${ }^{170}$

\section{B. Reasonableness}

Part I introduced two issues that implicate the reasonableness of the NEB's recommendations on pipeline approvals: the Board's refusal to consider upstream and downstream environmental effects (i.e. the scope of its assessment), and the adequacy of its assessment of a possible disaster. The principles of precaution and sustainable development allow us to take a purposive approach to evaluating the reasons offered by the NEB and identify the interests it must take into account when exercising its functions. The following examples show that the first task of the Court is to demand reasons that demonstrate the Board itself undertook this duty of justification seriously. In the absence of such, there is no basis on which a Court can defer.

\section{i. Scope of Assessment}

The NEB's justification for refusing to consider the environmental impacts of upstream production and downstream use that results from the construction of a new pipeline is that it does not have a statutory mandate to do so. The Board held that it is

\footnotetext{
169 David Dyzenhaus, "Constituting the Rule of Law: Fundamental Values in Administrative Law" (2002) 27 Queen's LJ 445 at 491.

170 See also: TRS Allan, Constitutional Justice: A Liberal Theory of the Rule of Law (Oxford: Claredon Press, 2001$).$
} 
"not persuaded that the effects from [oil sands] production are directly linked or necessarily incidental [to the Project]... the Project does not include upstream production and is not dependent on any particular upstream development... It is not the Board's recommendation that could directly or necessarily cause growth in oil sands development with its accompanying effects." 171

The Board has excluded consideration of downstream use because "[o] $]$ il, whether from Canada or from elsewhere in the world, will go to where the demand is, whether or not the Project proceeds." 172 At the same time, however, the entire purpose of constructing these pipelines is to facilitate oil sands development and subsequent consumption. ${ }^{173}$

Public justification requires that the Board offer a public-regarding reason for considering the economic benefits of oil sand development while excluding consideration of its environmental impacts. It is difficult to imagine that a permissible justification could be offered. Importantly, the "public" that the NEB must consider is broad, since reasonableness in this context is conditioned by the principle of sustainable development. The reasons that the NEB offers must therefore address the impacts on future generations and the entire globe because the proposed pipeline further entrenches Canada's commitment to oil sands development.

Reasonableness, in other words, is highly sensitive to context. In this context, the project, the nature of the environmental problem at issue, and the regulatory process itself all

${ }^{171}$ TMX List of Issues, supra note 28 at 3.

172 Ibid. at 4.

${ }^{173}$ Supra, note 30. NEBA, supra note 14 s 52(2) specifically lists the following factors: (a) the availability of oil, gas or any other commodity to the pipeline; (b) the existence of markets, actual or potential; (c) the economic feasibility of the pipeline; (d) the financial structure of the proponent; along with a catch-all factor "(e) any public interest that in the Board's opinion may be affected by the issuance of the certificate or the dismissal of the application." CEAA, supra note $16 \mathrm{~s} \mathrm{19(1)}$ also requires the determination of whether the project is likely to result in significant adverse environmental effects, taking into account the cumulative effects of the project. 
point in favour of a broad environmental assessment. A pipeline, by its very nature, is connected to other developments. It would make little sense to assess a pipeline as a disconnected entity. Some line-drawing by the Board will be necessary to limit the scope of its assessment. But what is not justified is the decision to draw the line differently for considering the benefits of pipeline development than for the environmental effects. In addition, failing to consider the cumulative effects of the project and the oil sands on global climate change ignores the interconnected nature of the environmental problem. Climate change is a classic collective action problem that results from countless individual activities that on their own have a relatively small impact. Finally, the NEB's process is detailed. It is the combination of two complex regulatory processes-under the $N E B A$ and $C E A A$ - that integrate economic, environmental and social considerations. To borrow words from the Supreme Court of Canada, reviewing a decision of the NEB on a related issue, it would be "surprising that such an elaborate review process would be created for such a limited inquiry." 174

The Board further justified its decision to limit the scope of its assessment by observing that greenhouse gas emissions from oil sands production and consumption are subject to separate regulatory processes. ${ }^{175}$ However, this is true of all environmental effects of all approved developments. The Board's justification must reflect the distinctive role of the assessment process. It is the only occasion on which a determination will be made about whether the project will proceed. The Board's assessment role is to report to Cabinet and to the

\footnotetext{
${ }^{174}$ Quebec (Attorney General) v Canada (National Energy Board), [1994] 1 SCR 159 at 191 [Quebec]. Note that the greenhouse gas emissions that the NEB considers in the pipeline assessments are those that result from valve leakage along the pipeline. This contribution to climate change is miniscule when compared to the production and consumption emissions from what is in the pipe.

${ }_{175}$ TMX List of Issues, supra note 28 at 3. But see: Quebec, supra note 174 at 194 ("the Board is the forum in which the environmental impact attributable solely to the export, that is, to the impact of the increase in power output needed to service the export contracts, will be considered. A focused assessment of these effects may be lost if subsumed in a comprehensive evaluation by the province of the environmental effects of the projects in their totality.”); Greenpeace, supra note 116 at para 335.
} 
public on whether, taking into account the social, economic and environmental complexities of the project, an approval is in the public interest.

\section{ii. Disaster Planning}

We saw in Part I that the NEB failed to consider the consequences of a major marine oil spill, assessing instead only the likelihood of such an event. We also saw that the Board has not required project proponents to produce and fully disclose site-specific emergency response plans for assessment, leaving this instead until after the project has been approved. The NEB's process is the only occasion on which it can address the question of whether, given the chance of a disaster and the proposed response, this project is in the public interest. The adequacy of this assessment directly engages the precautionary principle.

The precautionary principle precludes the NEB from shirking from a thorough consideration of a possible catastrophe. Gaps in the analysis - such as a failure to consider the consequences of an unlikely spill—cannot, on this view, be justified. In addition, site-specific emergency plans are not derivative matters to be worked out at a later date between Board members and the proponent. ${ }^{176}$ They are crucial factors in assessing both the likelihood and consequences of an emergency. The precautionary principle also instructs that it is not permissible for the Board to appeal solely to its own expertise in omitting these considerations. To the contrary, precaution strengthens the deliberative demands placed on the Board. Precaution requires that spill risk assessment and emergency plans are transparent and subject

\footnotetext{
${ }^{176}$ A recent audit of the NEB revealed that the Board has a horrendous track record on overseeing emergency planning by pipeline companies: Commissioner of the Environment and Sustainable Development, 2011 December Report of the Commissioner of the Environment and Sustainable Development (Ottawa: Government of Canada, 2011), online: Office of the Auditor General of Canada < http://www.oag-

bvg.gc.ca/internet/English/parl_cesd_201112_01_e_36029.html\#hd4b> at 1.46ff.
} 
to public and intervenor scrutiny. ${ }^{177}$ The Board must offer reasons for preferring one set of assumptions over another, ${ }^{178}$ and how all identified sources of uncertainty factored into its conclusion. All of these reasons, moreover, must be articulated in a way that is comprehensible to the public.

Precaution also requires appropriate review mechanisms to ensure the decision-maker has adequately scrutinized scientific analyses and accounted for uncertainty. The Federal Court recently elaborated the requirement of reasonableness in the environmental assessment context. It held that the "element of "justification, transparency and intelligibility within the decisionmaking process'....takes on a heightened importance." ${ }^{179}$ This conclusion follows from the purpose of environmental assessment - that is, to provide an evidentiary base on which the public, and the Cabinet which acts in its name, can rely. It also follows from a deliberative interpretation of the precautionary principle, which is squarely applicable when project proposals raise issues that "engage the realm of highly improbable, but possibility [sic] catastrophic, events." 180 According to the Court, such issues should not be discounted by the expert body, but should be put before political decision-makers — i.e. Cabinet — because they require a determination of "society's chosen level of protection against risk." 181 These issues are

\footnotetext{
${ }^{177}$ If Board members do not have the expertise to adequately assess the proponent's information or weigh the conflicting evidence of the proponent and intervenors, then it needs to appoint an independent expert to help it do so. CEAA, supra note $16 \mathrm{~s} 45$ allows for a review panel to appoint an expert. NEBA, supra note $14 \mathrm{~s} 10$ gives the Governor in Council the authority to appoint an expert, so presumably the NEB could make a request to the GIC to do so.

178 JRP Volume 2, supra note 30 at 130 (noting the conflicting conclusions that can be draw from the studies but continuing it "focused on the effects that were more readily measurable..."); BC Nature, supra note 32.

${ }_{179}$ Greenpeace, supra note 116 para 272 (quoting from Dunsmuir v New Brunswick (Board of Management), 2008 SCC 9, [2008]1 SCR 190 2008).

${ }^{180}$ Greenpeace, supra note 116 at para 331.

${ }^{181} \mathrm{Ibid}$. (this language is from the Framework on Precaution, supra note 99).
} 
presently before the Federal Court of Appeal, as the Northern Gateway Pipeline is the subject of numerous applications for judicial review. ${ }^{182}$

\section{Independence}

We have seen that there are a number of flaws in the NEB's decisions require a reviewing body to intervene to demand adequate justification by the Board. However, review operates as a last resort in cases of clear intransigence on the part of the Board to participate in the rule-of-law project. The willingness of the NEB to commit to the rule-of-law project is itself a product of the people that make up the Board and the informal institutional norms and pressures that influence them. It is predictable that a Board captured by industry, or unduly influenced by a pro-pipeline executive, will fail to maintain the rule-of-law project. We are thus faced with the question of what public justification requires of regulatory independence and how this issue might come before a court.

\section{i. Regulatory Capture}

As we have just seen, a deliberative interpretation of environmental principles requires close scrutiny from the court to ensure that decisions are the result of an appropriately deliberative process and that the decision is based on permissible reasons (i.e. reasons that, in fact, justify the decision). This level of scrutiny is especially necessary where there are clear signals that the decision-maker's deliberative capacity is impaired. A number of factors suggest that this is the case with the NEB. For example, no current Board members have expertise in environmental assessment or spill risk assessment, the Board has shared "intelligence" on the

\footnotetext{
182 Supra note 10.
} 
peaceful activities of pipeline opponents with industry, and has consistently failed to publicly justify many of its decisions, as indicated above.

The requirement of public justification requires deference to expert decision-makers, but only when deference is earned. A court committed to the rule-of-law project of public justification cannot turn a blind eye to allegations of regulatory capture and limit its inquiry to the language of the statute. The actual operations of the regulator - the representativeness of the board members, whether the process included submissions by a broad range of interests and whether the Board was responsive to those interests - are all relevant when the court assesses the adequacy of the justification offered by the Board in its reasons. ${ }^{183}$ Where capture is a plausible factor, public justification requires that the court subject the decision to more intense scrutiny. The Court should be less willing to fill in the blanks of the Board's reasoning and more willing to remit the decision for reconsideration.

This is not to pretend that judicial intervention is the remedy to regulatory capture. Capture is a pernicious problem that is often only detected in the most extreme cases. Preventing regulatory capture requires a cooperative effort amongst all institutions of government where public officials approach their roles purposively. ${ }^{184}$ Just as decades of conflict in the forestry sector resulted in the creation of a hybrid administrative body, British Columbia's forestry "watchdog," we could imagine similar institutional innovation playing a

\footnotetext{
${ }^{183}$ Leckey, supra note 20 at 237-9 (arguing that a contextual approach to judicial review can accommodate the vastly different kinds of relationships that administrative decision-makers have with individuals and the public, including requiring distance between decision-makers and the repeat players of a regulated industry). ${ }_{184}$ Arguably one of the most important factors here is the appointment of competent and open-minded Board members in the first place. I can't address this issue adequately here but see: Lorne Sossin, "The Uneasy Relationship between Independence and Appointments in Canadian Administrative Law" In Grant Huscroft, Michael Taggart eds, Inside and Outside Canadian Administrative Law: Essays in Honour of David Mullan (Toronto: University of Toronto Press, 2006) 50; Woolley, supra note 48 at 182 (how this requirement follows from a deliberative democratic understanding of public administration).
} 
similar role in preventing capture in the pipeline sector. ${ }^{185}$ Judicial review cannot prevent capture, but it can serve as a spotlight on the most egregious cases. As we have seen, construing the requirements of reasonableness and fairness in light of environmental principles should make capture easier to detect. Anchoring these principles in the rule-of-requirement of public justification offers a basis for judicial intervention when problems of regulatory capture emerge.

The NEB is aware of the widespread perception that it is beholden to the energy industry. Recent efforts, such as the Chairperson's cross-country tour, seek to restore public confidence in the Board's ability to fulfill its public interest mandate. ${ }^{186}$ But these efforts are palliatives. The Board has failed to recognize that its legitimacy does not come solely from appealing to the language of its governing statute or its professional expertise. Rather, its legitimacy - both legal and democratic legitimacy - comes from institutional practices that are demonstrably justified to those who are affected by its decisions.

\section{ii. Independence from Government}

In a sense, it is somewhat surprising that the specific requirements of public justification seem to elude the NEB. The NEB, after all, is not the ultimate decision-maker; Cabinet makes

\footnotetext{
${ }_{185}$ Chapter 5 supra on FPB. The Alberta Environmental, Monitoring, Evaluation and Reporting Agency, an independent scientific body that provides "open and transparent access to scientific data and information on the condition of Alberta's environment," established under the Protecting Alberta's Environment Act, SA 2013, c P-26.8, is another interesting development in this respect. Although this body would not directly respond to the issues with the NEB discussed here. See AEMERA online: <http://aemera.org//>. See Shaun Fluker, "Protecting Alberta's Environment Act: A Keystone Kops Response to Environmental Monitoring and Reporting in Alberta” (2 January, 2014) ABLawg online: <ablawg.ca> for some problems with the new regulatory body. However, this is not a complete answer, since it depends upon the specialized review body also retaining its independence from special interests (including now the primary decision-maker).

${ }_{186}$ Supra note 1. Somewhat better is its new online interactive pipeline map which improves public accessibility to oil spill and response data, but this ignores the prospective role of the NEB in helping approve these pipelines in the first place.
} 
the final decision. This raises the question of whether the NEB's process is a sham, windowdressing for a decision that is fixed in advance. This possibility is heightened by the fact that the responsible Minister expressed inflammatory and threatening views about those concerned with the Northern Gateway Pipeline. These comments cannot be undone and risk undermining the NEB's process. At least, however, these comments were public and contemporaneous with the NEB's process. We could imagine that, were the NEB committed to the rule-of-law project, such comments would have a galvanizing effect. The Board would be even more determined to foster an inclusive and deliberative process that demonstrated its independence from the executive. Such a process would not be sham even if the proposal were approved. This is because a publicly justified NEB recommendation would provide the public the information it needs to hold the ultimate decision-maker democratically accountable.

More problematic is the fact that the NEBA specifically and unambiguously allows the Chairperson and Minister to interfere with the NEB hearing process. This statutory language is directly at odds with the NEB's role to offer an informed recommendation on whether pipeline approval is in the public interest. The integrity of the process of public justification requires that the Chairperson and the Minister not exercise this statutory power. To do so would mean there is no genuine process in place, that the approval process is a sham.

But what if the Minister were to intervene and direct the Chairperson to issue a recommendation that a pipeline is in the public interest? ${ }^{187}$ In such a case the action would have clear statutory authority and yet would not comply with the requirements of the publicjustification conception of the rule of law. The Court would have to declare that, while the

\footnotetext{
187 Supra note 41.
} 
decision may comply with the statute, it has questionable legal authority. This is fundamental to the rule-of-law theory introduced in Chapter 5. Compliance with the rule of law is constitutive of legal authority. When the government exempts itself from the rule-of-law project, it loses its claim to the special kind of authority that comes from governing through law. While the court enforces the clear language of the statute, in such a worst-case scenario, it does so because the statute is valid, not because it has legal authority. ${ }^{188}$ Put differently, the fact that the court cannot invalidate the provision of the statute does not mean it is bound to endorse its authority as law. ${ }^{189}$ A court in such a situation can uphold the statute while also declaring that it undermines the fundamental commitment to the rule of law.

According to Dyzenhaus, the dynamic at play in common law judicial review is akin to the dynamic created by s 33 of the Charter:

"The [s33] override does not render any of the overridable values unconstitutional. It merely gives to the legislature a limited opportunity to operate unconstitutionally, but on condition that it owns up to that fact. The override is meant to, and does, both incite and renew democratic debate about the government's decisions to govern outside the constitutional order." 190

One could imagine the renewed democratic debate that might follow a judicial declaration that the federal government has decided to operate outside the rule of law by conducting a sham hearing for approving the construction of a controversial, interprovincial pipeline. ${ }^{191}$ This extreme scenario again brings to the surface the fundamental connection

\footnotetext{
${ }_{188}$ David Dyzenhaus, The Constitution of Law: Legality in a Time of Emergency (Cambridge: Cambridge University Press, 2006) at 206.

189 Ibid.

190 Ibid. at 211 (also observing that the UK Human Rights Act creates a similar dynamic).

191 Indeed many observers of the process have reached this conclusion on their own, even without actual Ministerial interference.
} 
between administrative and constitutional law. The court's role, in both cases, is to uphold core constitutional principles and alert the public when the executive has elected to exempt itself from the rule-of-law project.

\section{Conclusion}

This chapter has argued that public justification imposes specific requirements on environmental decision-makers. In the environmental context existing common law principles are inadequate to preserve the distinctive relationship between legal subject and state that the public-justification conception of the rule of law makes possible. Well-known environmental principles such as sustainable development and precaution have the potential to preserve this relationship when interpreted in light of deliberative democratic ideals.

In making this argument I have engaged in the exercise of what Elizabeth Fisher calls "administrative constitutionalism." That is, I have set out a normative argument about "the different roles that law can, and should, play in constituting and limiting public administration." ${ }^{192}$ Fisher identifies two potential and opposing paradigms of administrative constitutionalism. Under the rational-instrumental paradigm, public administration is construed as instrumental to the legislature and thus must operate through rational methodologies to pursue legislative goals. ${ }^{193}$ In contrast, the deliberative-constitutive paradigm "grant $[\mathrm{s}]$ to public administration substantial and ongoing problem-solving discretion in

192 Elizabeth Fisher, "Food Safety Crises as Crises in Administrative Constitutionalism" (2010) 20 Health Matrix 55 at 56; Fisher, supra note 118 at 24.

${ }^{193} \mathrm{Ibid}$. at 28. Something resembling a rational-instrumental understanding of public administration would follow from the formal conception of the rule of law. We saw this in Chapter 3 Part III with the possible solutions offered by the environmental reform position. 
relation to particular issues." ${ }^{194}$ The deliberative-constitutive paradigm understands regulatory issues as dynamic and thus requires administration to be engaged and responsive. ${ }^{195}$ While Fisher's paradigms emerge from a thick, socio-legal analysis of public administration, I have demonstrated that a deliberative-constitutive conception of administrative decision-making follows from a public-justification conception of the rule of law. Through this line of argument, I have demonstrated that administrative decisions can have both democratic and legal authority even in instances of deep complexity. Furthermore, I have connected a deliberative-constitutive understanding of administrative decision-making to an existing common law methodology for judicial review. And I have shown that, when properly understood, core common law principles impose specific requirements on administrative decision-makers who are otherwise relatively unconstrained by statutory language or predetermined expert methodologies.

Some may question whether I have delivered on the promise at the outset of this chapter to show how the rule of law offers concrete guidance in the specific context of the NEB's pipeline assessments. I have not definitively said "yes" or "no" to many of the issues raised by the NEB's assessments. Indeed, I have offered a theory of environmental law that does not definitively reject a series of major pipeline proposals that are nothing but bad news for the environment. What I have offered instead is something more powerful; that is, a set of questions that the NEB must answer to in order to comply with the rule of law. These questions do not arise from contested claims about ecological thresholds or from the din of climate activists or environmental politics more generally. Rather, they arise from a much deeper commitment to democratic governance under the rule of law. In addition to these deep commitments, Canadian environmental law contains further specific commitments to principles

\footnotetext{
${ }^{194}$ Ibid. at 30.

195 Ibid. at 30-1.
} 
of precaution and sustainable development. However under-developed the principles may be, or how cynical or hypocritical public officials are when they appeal to these principles, they remain existing commitments from which we can derive concrete and rigorous legal requirements for environmental regulators. In this chapter I have shown that the public-justification conception of the rule of law provides a theoretical framework in which these principles play a meaningful interpretive role. They are an integral part of the rule-of-law project in environmental law, which is the project of respecting and enabling individuals as responsible agents, capable of reasoning with the law and participating in environmental governance. 


\section{Conclusion}

The thesis began by noting the absence of a theory of environmental law that contained a sophisticated account of the rule of law capable of taking seriously the profound complexity of environmental issues. That gap provided the basis for the account of environmental law that followed in the five substantive chapters of the thesis. I argued that the best way to conceive of environmental issues is as an ongoing emergency. Like emergencies, environmental issues contain the unforeseeable possibility of a catastrophe. Our inability to know in advance which issues or policy choices raise the possibility of a catastrophe combined with our inability to know in advance how to respond to such an unforeseen event justifies viewing environmental issues from this perspective. We saw that approaching environmental law from the emergency perspective means it is susceptible to Schmitt's challenge: i.e., the challenge to show how environmental issues can be governed by law. Schmitt's challenge and possible responses to it in the national security context provided the framework for the argument. I argued that the environmental emergency provided a novel critique of existing environmental law literature. It also provided the basis for articulating a democratic conception of the rule of law that can operate under conditions of deep complexity.

The theory of the rule of law developed in the thesis begins with the assumption that all institutions of government cooperate in a rule-of-law project of public justification. All public officials must publicly justify their exercises of authority on the basis of core constitutional principles in order to possess legal authority. Individuals can contest decisions on the ground that they are not so justified and other institutions of government are entitled to intervene on this basis. I argued that the complexity of environmental issues demands significant 
institutional creativity to enable public justification. Public justification will often only be possible when decisions are the product of robust public deliberation on concrete evidence and prior experience. Moreover, review of these decisions cannot be the sole responsibility of the courts. The complexity of environmental decisions requires a variety of review mechanisms such as environmental tribunals and novel hybrid institutions to ensure that the full range of environmental decisions reflects core constitutional principles. In short, maintaining the ruleof-law project in the environmental context requires an ongoing commitment to public justification, and this entails a further commitment to institutional experimentation to ensure that especially challenging regulatory decisions are justified.

This public-justification conception of the rule of law is a stark departure from existing rule-of-law requirements in Canadian environmental law. In Chapter 3, we saw that the formal conception of the rule of law persists across a wide range of environmental decisions subject to judicial review. Judges who adhere to the formal conception try to "accommodate" discretionary environmental decisions within legal order by subjecting these decisions to minimal rule-of-law constraints. This occurs through the creation of legal black holes and grey holes that arise where formalist judges enforce the boundaries imposed by the statute, but do not supervise the exercise of administrative discretion. While this problem of discretion has been correctly diagnosed by reform-oriented academics, I argued that their adherence to the "environmental reform position" also assumed a formal conception of the rule of law. Environmental reformers do not face up to the environmental emergency, and their solutions of environmental rules and independent decision-makers cannot, on their own, deliver the legal constraints they seek. 
In Chapter 4, we saw that the growing attention to novel forms of environmental governance has also, by and large, equated the rule of law with the formal conception of the rule of law. Because governance scholars appreciate the complexity of environmental issues they are forced-like proponents of extra-legal emergency measures-to dismiss the rule of law as irrelevant. They turn instead to criteria of effectiveness, transparency, participation and accountability to assess governance approaches. Law, on this view, is purely instrumental and can be dispensed with whenever it does not serve these alternative criteria. I argued that, while scholars of environmental governance rightly reject the formal conception of the rule of law, they fail to adequately address its underlying concerns. They do not, in other words, attend to why the rule of law is something worth having in the first place. Both proponents of environmental governance and environmental reformers were seen to fail Schmitt's challenge.

The answer to Schmitt's challenge came in Chapters 5 and 6, where I developed the public-justification conception of the rule of law and argued that it can govern complex environmental decisions. This public-justification conception emerges from the commonalities between existing theories of common law constitutionalism and deliberative democracy, both of which respect the individual as a rational and self-determining agent who is capable of reasoning with the law. Public justification means that those subject to the law are treated as active participants in their systems of governance.

I argued that this conception of the rule of law is superior to the formal conception for two main reasons. The first is that it accepts the necessity of administrative discretion for responding to complex and contentious environmental issues but, unlike the formal conception, subjects the exercise of this discretion to legal constraints. Administrative discretion must be 
exercised consistently with core common law principles of fairness and reasonableness. Unlike the static institutional roles presumed by the formal conception, the public-justification conception further requires creative institutional design to ensure that decisions reflect these core constitutional principles even in complex settings. The second reason is that the publicjustification conception responds to the democratic deficit otherwise left by the formal conception. We saw that public justification builds democracy in from the beginning. It requires a "culture of justification," ${ }^{1}$ where individuals publicly deliberate over how to govern themselves. Individuals can then contest decisions on the basis that they do not reflect the contents of these deliberations thereby furthering public deliberation on what the law is and ought to be.

The public-justification conception is aspirational; it requires an ongoing commitment and can never be perfectly achieved. But by identifying particular instances of justification we can better understand how we can continue to strive toward this aspiration. In Chapter 5 , I offered the British Columbia Forest Practices Board as an example of the kind of creative institutional design that is capable of approximating the rule-of-law requirement of public justification, albeit in an unconventional way. As a specialist hybrid institution with a variety of administrative powers, we saw that the Forest Practices Board was able to thoroughly address the provincial government's controversial response to the mountain pine beetle epidemic. We saw that, even after the province changed its command-and-control legislation to a flawed form of environmental governance, the Board has continued to supervise its implementation and propose extensive reforms that would better align the new forestry regime with the requirement of public justification.

${ }^{1}$ David Dyzenhaus, "The Legitimacy of Legality" (1996) 46 UTLJ 129 at 162. 
Chapter 6 argued that the requirement of public justification provides a natural theoretical basis for developing existing environmental principles such as sustainable development and precaution. I defended these environmental principles on the basis that they operate to protect the distinctive relationship between legal subject and state that the publicjustification makes possible. A deliberative-democratic interpretation of sustainable development and precaution operates to broaden the range of interests that must be considered in any environmental decision, intensify the scrutiny of novel issues or decisions that raise the possibility of a disaster, and formalize mechanisms of public participation. Construed in this way, sustainable development and precaution modify the requirements of core common principles of fairness and reasonableness for the environmental context. I offered the example of Canada's National Energy Board and its process for determining whether major pipelines are in the public interest. And I argued that it has failed to publicly justify many of its current practices meaning that, at present, the approvals of these major pipelines lack legal authority.

The rule-of-law theory developed in Chapters 5 and 6 may give rise to three lingering and cumulative concerns. Skeptics may worry that I have not sufficiently attended to the need for environmental protection, I have assumed too much of public officials and the public, and I have diluted the requirements of the rule of law and deprived it of its critical force. I first set out what I suspect are the primary drivers behind these concerns. I respond to these concerns collectively by drawing out the main themes of the thesis.

\section{Residual Worries}


A first concern may arise from the fact that the rule-of-law theory focuses on the procedures for making environmental decisions rather than the substance or outcome of any given environmental decision. It does not prioritize environmental values and makes no guarantee of environmental protection. For these reasons, skeptics may argue that, by failing to fix some ecological objective in advance, ${ }^{2}$ I leave the development of environmental laws vulnerable to the influence of powerful actors (such as industry) or the vagaries of public opinion. ${ }^{3}$

From here, it is only a small step to the second concern: that it is naïve, or worse irresponsible, to set out an aspirational conception of the rule of law if we indeed face the possibility of environmental catastrophe, as I argue. An aspirational conception of the rule of law, it might be argued, creates a moral hazard that implicitly condones failures to meet its high standards. On this point, skeptics might argue that my theory assumes too many ideal conditions for administrative decision-making or that an ongoing requirement of public justification is simply too much to expect of our flawed institutions of governance and an apathetic or disaffected public. ${ }^{4}$ We must, therefore, consider the consequences of falling well short of these rule-of-law and democratic aspirations.

\footnotetext{
${ }^{2}$ For example, my critique of the "ecological sustainable development" proponents in Chapter 6, supra.

${ }^{3}$ Cristie Ford, "New Governance in the Teeth of Human Frailty: Lessons from Financial Regulation" (2010) Wis L Rev 441(noting how powerful players can exploit conditions of uncertainty) [Ford]; Annecoos Wiersema, "A Train without Tracks: Rethinking the Place of Law and Goals in Environmental and Natural Resources Law" (2008) 38 Envtl L 1239 (how commitment to specific environmental goals wanes over time allowing for economic interests to creep back into the picture); Bruce Pardy, "Environmental Assessment and Three Ways Not to Do Environmental Law" (2010) 21 Journal of Environmental Law and Practice 139 at 140 (how procedures without substance are an "empty pretence"); Martin Olszynski, "Environmental Monitoring and Ecosystem Management in the Oil Sands: Spaceship Earth or Escort Tugboat?" (2014) 10 McGill Int'l J Sust Dev L \& Pol'y 1 (on how loose adaptive management practices are a "smokescreen for unbounded agency discretion" internal footnote omitted).

4 These are frequent critiques launched at democratic experimentalism: William E Scheuerman, "Democractic Experimentalism or Capitalist Synchronization-Critical Reflections on Directly-Deliberative Polyarchy" (2004) 17 Can JL \& Jurisprudence 101 at 120-1 (paradox of seeming to require greater equality before a democratic experimentalist approach could work, whether so much deliberation is feasible in a fast-paced world); Jody
} 
Finally, critics might wonder whether I have diluted the requirements of the rule of law. They might point out that environmental appeals tribunals, ombudsmen, auditors general and creative institutional design generally, for all their merits, are not courts. ${ }^{5}$ They are not independent and their members do not necessarily approach their role, as Dicey said, "in the general spirit of the common law." ${ }^{6}$ Skeptics may therefore argue that, far from upholding the rule of law, my theory only adds more layers onto the façade of legality.

\section{The Rule of (Environmental) Law}

In the introduction of the thesis I noted that this thesis was not a project of law reform. It is important to return to this point in order to re-emphasize that nothing about this theory goes against the enactment of ambitious and strict environmental legislation. The concept of the environmental emergency is not a license for unconstrained administrative discretion. It is rather a recognition that, no matter how hard we might try to put in place clear and strict environmental rules, they can never capture the full range of environmental circumstances which we will later face. Nor can they anticipate how to best to proceed when the possibility of an environmental disaster arises.

In light of this complexity, we may decide in any given case to proceed by way novel environmental governance or by way of "prophylactic rules."7 As we saw in Chapter 4, there is a growing body of empirical literature exploring the relative merits of each of these approaches

Freeman \& Daniel A Farber, "Modular Environmental Regulation" (2005) Duke L J 795 at 834 (democratic experimentalism rests on an idealized participatory democracy and assumes "effortless jet-propulsion").

${ }^{5}$ Ron Ellis, Unjust by Design: Canada's Administrative Justice System (Vancouver: UBC Press, 2013).

${ }^{6}$ AV Dicey, An Introduction to the Study of the Law of the Constitution 10th ed, (Toronto: MacMillan Company of Canada Ltd, 1959) at 413.

${ }^{7}$ Ford, supra note 3 at 475. 
for environmental protection. In contrast to this existing literature, the aim of the thesis has been to demonstrate that a democratic conception of the rule of law can operate under the conditions of the environmental emergency. Moreover, I have sought to show that approaching environmental law from a rule-of-law perspective is a worthwhile endeavor. The relevant comparison for the purposes of this thesis is not, therefore, between rules and discretion or law and governance. Rather, it is between the formal conception of the rule of law and its potential alternatives. I have argued that a public-justification conception of the rule of law provides the legal constraints under the conditions of the environmental emergency that the formal conception cannot.

I have defended the public-justification conception largely on republican and liberal grounds, that it protects individuals from arbitrary public decisions. By requiring public officials to offer defensible reasons and by providing institutional channels for contestation, public-justification recognizes the autonomy of individuals and their capacity to actively participate in their institutions of governance. I do not base my argument on any guarantee that the public-justification conception will lead to better environmental protection or help us avoid environmental catastrophe, as I do not have the empirical evidence to support this claim (and if I am right about complexity, it is unlikely to be available). However, existing deliberative-democratic literature suggests that there is reason to think this conception will put us on a trajectory for better environmental decision-making. ${ }^{8}$ As we saw, public justification requires institutional decision-making conditions that broaden the range of views considered, it

\footnotetext{
${ }^{8}$ Kerry H Whiteside, Precautionary Politics: Principle and Practice in Confronting Environmental Risk (Cambridge, Mass: MIT Press, 2006) at 126-132 (defending a deliberative interpretation of the precautionary principle on epistemic grounds); Jenny Steele, "Participation and Deliberation in Environmental Law: Exploring a Problemsolving Approach" (2001) 21 Oxford Journal of Legal Studies 415 (on the compatibility of legitimacy and epistemic rationales for increased public participation in environmental law). But see: Henry S Richardson, Democratic Autonomy: Public Reasoning About the Ends of Policy (Oxford: Oxford University Press, 2002) at 77-8 (on why it would be too quick to base the defence of deliberative democracy solely on epistemic grounds) [Richardson].
} 
requires decision-makers to offer responsive reasons, and it requires processes for contestation that force us to reconsider and revise our public decisions. We also saw that this is a significant departure from existing institutional arrangements that tend to privilege industry involvement in administrative decision-making, and limit the opportunities for review. It is also a significant departure from the formal conception, which rests on unrealistic assumptions about the ability of the legislature and courts to constrain administrative powers, and makes no room for the development of environmental principles.

\section{The Science/Democracy Interface}

At the same time, however, the public-justification conception does not rest on romantic notions of enlightened local knowledge, dispassionate deliberation, or consensus-based decisions. It accepts the need for professional administrative expertise, for example, the National Energy Board. It recognizes the vital role of scientific expertise in sound environmental decision-making. Importantly, however, public-justification construes these forms of expertise as public goods, tools that can help us better govern ourselves. ${ }^{9}$ It therefore does not discount the contributions that non-experts can make to deliberations over complex regulatory issues.

As we saw in Chapter 5, public-justification allows us to appreciate public institutions as purposive endeavours that respect the reasoning capacity of individuals and enable their active participation in collective governance. Rational and self-determining individuals do not exist in the abstract; our capacity to participate in collective governance is realized through our public

\footnotetext{
${ }_{9}^{9}$ Ibid. at 22516 (on administrative "evaluative" expertise); Michael C Dorf \& Charles F Sabel, "A Constitution of Democratic Experimentalism" (1998) Columbia Law Review 267 at 415.
} 
institutions. ${ }^{10}$ Accepting that we need these institutions, the question is how to prevent them from making arbitrary decisions that depart from the public good or undermine fundamental constitutional commitments. I have argued that the requirement of public justification provides the answer.

The theory presented here therefore cannot be categorized as either a science-based or democracy-based approach to environmental law. ${ }^{11}$ One strength of the public-justification conception is its insistence that context always matters. In some instances, science will provide a clear basis for political action, such that a decision that ignores the relevant scientific expertise cannot be justified. In other instances, those subject to the decision will have serious doubts about expert assurances that threats are trivial, unlikely or can be adequately managed. In other instances still, conflicting scientific expertise can be dispelled through a careful examination of the source and methods of these conflicting accounts. ${ }^{12}$ It is ultimately unhelpful, as we saw with binary treatments of the precautionary principle, to talk about "the science" and "the public" in monolithic terms. In every instance, public justification requires that the public official offer accessible reasons that disclose the fairness and reasonableness of the decision. This is a necessarily context-sensitive requirement.

\section{Democratic Legality}

\footnotetext{
${ }^{10}$ Dewey, whose work heavily influences democratic experimentalism, is particularly strong on this point: John Dewey, The Public and Its Problems (Chicago: The Swallow Press Incorporated, 1954) at 148 ff. However, one need not accept all of Dewey's assumptions about democracy ( $c f$ Lon L Fuller, "Means and Ends" Kenneth I Winston eds, The Principles of Social Order: Selected Essays of Lon L Fuller Rev ed (Oxford \& Portland: Hart Publishing, 2001) 61 at 72) to appreciate the fact that multiple and complex public institutions are a fact of life in any modern society: Richardson, supra note 8 at 222.

${ }^{11}$ Elizabeth Fisher, Risk Regulation and Administrative Constitutionalism (Oxford and Portland OR: Hart Publishing, 2007) at 3, 11-13 (on how much environmental law and policy scholarship is stuck in this tired and unhelpful dichotomy).

${ }^{12}$ Sunstein calls this "affiliation bias," though curiously he does not give this much weight in his promotion of technocratic decision-making: Cass R Sunstein, Risk and Reason: Safety, Law, and the Environment (Cambridge: Cambridge University Press, 2002) at 36.
} 
Finally, I have articulated a theory in which all institutions of government are partners in a collective commitment to democratic legality. This means that even unconventional legal institutions-such as the Forest Practices Board-can be understood as participants in maintaining the rule of law. Some may fear that, by including such institutions in the rule-oflaw project, I undermine the role of the court as the guardian of the rule of law. Yet this view rests on the assumptions of the formal conception, which, as we saw in Chapter 3, does not serve us well in the environmental context. In contrast, the public-justification conception envisions the courts playing a catalytic role. From this perspective, the role of judicial review is to require the other institutions of government to articulate more clearly the norms governing their decisions. Conversely, when creative institutions participate in the rule-of-law project in this way, they enable courts to better perform their role in ensuring the protection of fundamental constitutional principles.

The fact is, public officials always have two options available to them. ${ }^{13}$ They can interpret the law in a formal manner, which can lead to a vicious cycle in which the rule of law is understood as increasingly hollow in difficult cases. Alternatively, they can approach their roles purposively with the understanding that they are part of the rule-of-law project of ongoing public justification. As we have seen, public justification requires certain pieces of "constitutional furniture" to be put in place. ${ }^{14}$ The more furniture that is in place-specialized appeals tribunals, hybrid institutions - the harder it becomes step away from the rule-of-law project without paying a steep political cost. ${ }^{15}$ Even if these institutions are put into place with the intention to create a façade, they can take on an institutional life of their own, one that is

\footnotetext{
${ }^{13}$ David Dyzenhaus, "Cycles of Legality in Emergency Times" (2007) 18 Public Law Review 165.

${ }_{14}$ David Dyzenhaus, The Constitution of Law: Legality in a Time of Emergency (Cambridge: Cambridge University Press, 2006) at 233.

${ }_{15} \mathrm{Ibid}$. As we saw in Chapter 5 the FPB remains despite a radical (and arguably ideological) shift in forestry regulation. The FPB has become a major critic of the new regulation.
} 
committed to the requirement of public justification. Of course, there is no guarantee that this will happen. No theory or institutional design can protect against this. Understanding the rule of law as a project means that it is never secure; it is always in the hands of its participants.

As such, the rule-of-law theory elaborated in the thesis is an aspirational account. Nevertheless, it is both critical and constructive. It allows us to pinpoint institutions that have fallen down in their commitment to public justification and provides a basis for legal recourse, such as judicial review. But it also allows us to highlight those that have done particularly well. The existence of these latter examples shows that the commitment to democratic legality is achievable, if not ever perfectible.

The constitution of the environmental emergency reveals that the emergency is, in fact, the norm in environmental law. I mean this in two distinct senses. First is the very real sense in which the possibility of a disaster is inherent in environmental issues, though it is not always possible to foresee. This requires public officials to take this possibility seriously. That they have done so is revealed through their commitment to public justification. The second sense is that the environmental emergency leads us to a constitution of democratic legality that is fit for all issues at all times. This democratic conception of the rule of law requires environmental law to be more deliberative, more reasoned and always mindful of our vulnerability to catastrophic environmental harm. 


\section{Bibliography}

Legislation

Bark Beetle Regulation, BC Reg 286/2001.

Canadian Environmental Assessment Act, 2012, SC 2012, c 19, s 52.

Canadian Environmental Protection Act, 1999, SC 1999, c 33.

Canada National Parks Act, SC 2000, c 32.

Criminal Code, RSC 1985, c C-46.

Emergencies Act, RSC 1985, c 22 (4th Supp).

Emergency Management Act, SC 2007, c 15.

Endangered Species Act, 2007, SO 2007, c 6.

Environmental Bill of Rights, 1993, SO 1993, c 28.

Environmental Goals and Sustainable Prosperity Act, SNS 2007, c 7.

Environmental Management Act, SBC 2003, c 53.

Environmental Protection Act, RSO 1990, c E 19.

Environmental Protection and Enhancement Act, RSA 2000, c E-12.

Federal Sustainable Development Act, SC 2008, c 33.

Fisheries Act, RSC 1985, c F-14 s 7.

Forest Act, RSBC 1996, c 157.

Forest and Range Practices Act, SBC 2002, c 69.

Forest Planning and Practices Regulation, BC Reg 14/2004.

Forest Practices Code of British Columbia Act, RSBC 1996, c 159.

Kyoto Protocol Implementation Act, SC 2007, c 30 [repealed].

National Energy Board Act, RSC 1985, c N-7.

National Parks General Regulations, SOR/78-213.

Oceans Act, SC 1996, c 31.

Pest Control Products Act, SC 2002, c 28.

Protecting Alberta's Environment Act, SA 2013, c P-26.8.

Species at Risk Act, SC 2002, c 29.

Statutory Instruments Act, RSC 1985, c S-22.

Sustainable Development Act, CQLR c D-8.1.1.

Sustainable Development Act, The, CCSM c S270.

War Measures Act, RSC 1970, c W-2.

Foreign Legislation

Administrative Procedures Act, Pub L No 79-404, 60 Stat 237 (1946) (codified as 5 USC 551 et seq) (US).

Authorization for the Use of Military Force, Pub L No 107-40, 115 Stat 224 (2001) (US).

Resource Management Act 1991 (NZ)

Special Immigration Appeals Commission Act 1997, 1997 c 68 (UK)

Sustainability Victoria Act 2005 (V)

Sustainable Planning Act 2009 (Q) 
International Agreements

United Nations Conference on Environment and Development, Rio Declaration on Environment and Development, UN Doc A/CONF.151/26 (vol I); 31 ILM 874 (1992).

Jurisprudence

114957 Canada Ltée (Spraytech, Société d'arrosage) v Hudson (Town), 2001 SCC 40, [2001] 2 SCR 241.

Alberta (Information and Privacy Commissioner) v Alberta Teachers' Association, 2011 SCC 61, [2011] 3 SCR 654.

Alberta Wilderness Association v Minister of Environment, 2009 FC 710, [2009] FCJ No 876, 2009. Arsenault v Canada (Attorney General), 2009 FCA 300, 181 ACWS (3d) 840.

Association des crevettiers acadiens du Golfe inc v Canada (Attorney General), 2011 FC 305.

Baker v Canada (Minister of Citizenship and Immigration), [1999] 2 SCR 817, 1 Imm LR (3d) 1.

Bell Canada v Canadian Telephone Employees Association, 2003 SCC 36, [2003] 1 SCR 884.

Black v Advisory Council for the Order of Canada, 2013 FCA 267, 64 Admin L R (5th) 76.

Bow Valley Naturalists Society v Canada (Minister of Canadian Heritage), [2001] 2 FC 461.

Canada (Minister of Citizenship E̊ Immigration) v Khosa, 2009 SCC 12, [2009] SCR 339.

Canadian Council for Refugees $v$ Canada, 2008 FCA 229.

Canadian Parks and Wilderness Society v Canada (Minister of Canadian Heritage), 2003 FCA 197, [2003] FCJ 703197.

Canadian Society of Immigration Consultants v Canada (Citizenship and Immigration), $2011 \mathrm{FC} 1435$. Carpenter Fishing Corp v Canada, [1998] 2 FC 548, 155 DLR (4th) 572.

Cassiar Watch v Canada (Minister of Fisheries and Oceans), 2010 FC 152, [2010] FCJ No 282.

Castle-Crown Wilderness Coalition v Alberta (Director of Regulatory Assurance Division, Alberta

Environment), 2005 ABCA 283, 371 AR 370.

Castonguay Blasting Ltd v Ontario (Environment), 2013 SCC 52, [2013] 3 SCR 323.

Catalyst Paper Corp v North Cowichan (District), 2012 SCC 2, [2012] 1 SCR 5.

CUPE v NB Liquor Corporation, [1979] 2 SCR 227, 97 DLR (3d) 417.

David Suzuki Foundation et al v Attorney General for British Columbia, 2004 BCSC 620.

David Suzuki Foundation v British Columbia (Ministry of Environment), 2013 BCSC 874, 240

ACWS (3d) 641.

Doré v Barreau du Québec, 2012 SCC 12, [2012] 1 SCR 395.

Dunsmuir v New Brunswick (Board of Management), 2008 SCC 9, [2008] 1 SCR 190.

Environmental Defence Canada v Canada (Minister of Fisheries and Oceans), 2009 FC 878, [2009]

FCJ No 1052.

Flamborough (Town) v Canada (National Energy Board), 5 ACWS (3d) 109, [1987] FCJ No 460.

Friends of the Earth $v$ Canada (Governor in Council), 2008 FC 1183, [2009] 3 FCR 201.

Forest Ethics Advocacy Association v Canada (Attorney General), 2014 FCA 182.

Forest Ethics Advocacy Association and Sinclair v National Energy Board, 2014 FCA 245.

Gagnon and Vallières v The Queen (1971), 14 CRNS 321.

Greater Vancouver (Regional District) v Darvonda Nurseries Ltd, 2008 BCSC 1251, [2008] BCJ No 1788.

Greenpeace Canada v Canada (Attorney General), 2014 FC 463, [2014] FCJ No 515. 
Halifax (Regional Municipality) v Nova Scotia (Human Rights Commission), 2012 SCC 10, [2012] 1 SCR 364.

Imperial Oilv Quebec, $2003 \mathrm{SCC} 58$, [2003] 2 SCR 624.

Katz Group Canada Inc v Ontario (Health and Long-term Care), 2013 SCC 64, [2013] 3 SCR 810.

Kelly v Alberta (Energy Resources Conservation Board), 2009 ABCA 349.

Kelly v Alberta (Energy Resources Conservation Board), 2011 ABCA 325.

Kelly v Alberta (Energy Resources Conservation Board), 2012 ABCA 19.

Khan v University of Ottawa (1997) 34 OR (3d) 535, [1997] OJ No 2650, 1997.

Klahoose First Nation v Sunshine Coast Forest District, 2008 BCSC 1642, [2009] 1 CNLR 110.

Kostuch v Alberta (Director, Air \& Water Approvals Divisions, Environmental Protection), 1996

CanLII 10565 (AB QB), 35 Admin LR (2d) 160.

Lake Waseosa Ratepayers' Association v Pieper, 2008 CLB 1707, [2008] OJ No 728.

Loyola High School v. Quebec (Attorney General), 2015 SCC 12.

MacMillan Bloedel Ltd v British Columbia (Minister of Forests), [1984] 3 WWR 270, BCJ No 1472 (CA).

Malcolm v Canada (Minister of Fisheries and Oceans), [2014] 2014 FCA 130, 76 Admin LR (5th) 179.

McLean v British Columbia (Securities Commission), 2013 SCC 67, [2013] 3 SCR 895.

Minister of Fisheries and Oceans v David Suzuki Foundation, 2012 FCA 40.

Montague v Ontario (Ministry of Environment), 12 CELR (3d) 271, [2005] OJ No 868.

National Corn Growers Assn v Canada (Import Tribunal), [1990] 2 SCR 1324

Newfoundland and Labrador Nurses' Union v Newfoundland and Labrador, 2011 SCC 62, [2011] 3 SCR 708.

Nicholson v Haldimand-Norfolk Regional Police Commissioners, [1979] 1 SCR 311, 88 DLR (3d) 671.

Nor-Man Regional Health Authority v Manitoba Association of Health Care Professionals, 2011 SCC 59, [2011] 3 SCR 616.

Northwood Inc v British Columbia (Forest Practices Board), 2001 BCCA 141, 2001 CarswellBC 389

Pacific Booker Minerals Inc v British Columbia (Minister of the Environment), 2013 BCSC 2258, 236 ACWS (3d) 641.

Pembina Institute for Appropriate Development v Canada (Attorney General), 2008 FC 302, [2008]

FCJ No 324.

Quarmby v Attorney General of Canada, [2015] SCCA No 113 (QL), File No 36353.

Quebec (Attorney General) v Canada (National Energy Board), [1994] 1 SCR 159.

$R v$ Consolidated Maybrun Mines Ltd, [1998] 1 SCR 706.

Red Mountain Residents and Property Owners Assn v British Columbia (Ministry of Forests, British

Columbia Forest Service, Arrow Forest District), 2001 BCSC 1142, 40 CELR (NS) 117.

Rio Tinto Alcan Inc v Carrier Sekani Tribal Council, 2010 SCC 43, [2010] 2 SCR 650.

Sandy Pond Alliance to Protect Canadian Waters Inc v Attorney General of Canada, 2013 FC 112. Sierra Club Canada v Ontario (Ministry of Natural Resources), 2011 ONSC 4655, [2011] OJ No 4373.

Suresh v Canada (Minister of Citizenship and Immigration), 2002 SCC 1, [2002] 1 SCR 3

Vancouver Island Peace Society v Canada, [1992] 3 FC 42, 53 FTR 300.

Ward v Canada (Attorney General), [2002] 1 SCR 569.

Western Canada Wilderness Committee v British Columbia (Ministry of Forests, South Island Forest

District), 2003 BCCA 403, [2003] BCJ No 1581. 
Western Canada Wilderness Committee v British Columbia (Forests, Lands and Natural Resource Operations), 2014 BCSC 808, 84 CELR (3d) 85.

Western Canada Wilderness Committee $v$ Canada (Minister of Fisheries and Oceans and Minister of the Environment), $2014 \mathrm{FC} 148$.

Wier v Canada (Minister of Health), 2011 FC 1322.

\section{Foreign \& International Jurisprudence}

Case Concerning the Gabcikovo-Nagymaros Dam (Hungary v Slovakia), [1997] ICJ Rep 7.

Hamdi v Rumsfeld, [2004] 124 S Ct 2633 (US).

Norton v Southern Utah Wilderness Alliance, 542 US 55 (2004) (US).

Secretary of State for the Home Department v MB [2007] QB 415 (UK).

Telstra Corp Ltd v Hornsby Shire Council, [2006] NSWLEC 285 (Aus).

\section{Tribunal Jurisprudence}

Babine Forest Products Ltd v Government of British Columbia, (2013) 2011-FOR-006(a) (Forest Appeals Commission).

In the Matter of Enbridge Pipelines Inc, OH-002-2013, (National Energy Board, 2014).

In the Matter of TransCanada Keystone Pipeline GP Ltd, OH-1-2009, (National Energy Board, 2012).

Motions requesting the Board include in the List of Issues the environmental and socio-economic effects associated with upstream activities and downstream use (23 July 2014), OH-OO1-2014 Ruling No 25 [Trans Mountain] (National Energy Board, 2014).

Mr LD Danny Harvey - notice of motion dated 12 August 2014, (19 August 2014) OH-001-2014 Ruling No 29 [Trans Mountain] (National Energy Board, 2014).

Ms Lynne M Quarmby and others - notices of motion dated 6 and 15 May 2014, (2 October 2014), Order OH-00 1-2014 Ruling No 34 [Trans Mountain], (National Energy Board, 2014).

Notices of motion from Ms Robyn Allan and Ms Elizabeth May to include cross-examination of witnesses (7 May 2014), OH-O01-2014 Ruling No 14 [Trans Mountain] (National Energy Board, 2014).

Procedural Update No. 2 - Ruling on Participation and Updated Timetable of Events (22 May 2013), OH-OO2-2013 [Line 9] (National Energy Board, 2013).

Ruling on Participation (2 April 2014), OH-O01-2014 [Trans Mountain], (National Energy Board, 2014).

Province of British Columbia (Province) notice of motion dated 5 December 2014 (15 January 2015), OH-OO 1-2014 Ruling No 50 [Trans Mountain] (National Energy Board, 2015).

\section{Government Documents}

British Columbia, Legislative Assembly, Official Reports of Debates (Hansard), $37^{\text {th }}$ Parl, $2^{\text {nd }}$ Sess, Vol 10 No 3 (6 Nov 2002). 
Berger, Thomas R. Northern Frontier, Northern Homeland: The Report of the Mackenzie Valley

Pipeline Inquiry, Vol. 1 (Ottawa: Supply and Services Canada, 1977).

Canada. "Backgrounder: Security of Canada Information Sharing Act", (January 2015), online:

Government of Canada <http://news.gc.ca/web/article-en.do?nid=926879>.

Commissioner of the Environment and Sustainable Development. 2011 December Report of the

Commissioner of the Environment and Sustainable Development (Ottawa: Government of Canada, $2011)$.

Connections: Report of the Joint Review Panel for the Enbridge Northern Gateway Project

Volume 1 (2013), online: Gateway Panel <http://gatewaypanel.review-examen.gc.ca/>.

Considerations: Report of the Joint Review Panel for the Enbridge Northern Gateway Pipeline

Volume 2 (2013), online: Gateway Panel <http://gatewaypanel.review-examen.gc.ca/>.

The Council of the Federation. Canadian Energy Strategy (The Council of the Federation, 2015).

A History of the Battle Against the Mountain Pine Beetle (Government of British Columbia,

2012).

Intergovernmental Panel on Climate Change, Climate Change 2014: Impacts, Adaption, and

Vulnerability Summary for Policy Makers (2014).

Forest and Range Evaluation Program Strategic Plan 2011-2013 (Victoria: Government of

British Columbia, 2011).

Forest Practices Board. Approval of Large Cutblocks to Control Mountain Pine Beetle in the

Robson Valley, FPB/IRC/69 (Victoria: Government of British Columbia, 2002).

- Balancing Community Needs and Pine Beetle Logging in the Robson Valley, FPB/IRC/78

(Victoria: Government of British Columbia, 2002).

_. Evaluating Mountain Pine Beetle Management in British Columbia, FPB/SR/20 (Victoria:

Government of British Columbia, 2004).

—. Nadina Beetle Treatments, FPB/IRC/99 (Victoria: Government of British Columbia,

2004).

- A Review of the Early Forest Stewardship Plans Under FRPA, FPB/SR/28 (Victoria:

Government of British Columbia, 2006).

—. The Effect of Mountain Pine Beetle Attack and Salvage Harvesting on Streamflows,

FPB/SIR/ 16 (Victoria: Government of British Columbia, 2007).

- Biodiversity Conservation During Salvage Logging in the Central Interior of BC, FPB/SR/35

(Victoria: Government of British Columbia, 2009).

Great Expectations - Forest Stewardship Plans in BC (Victoria: Government of British

Columbia, 2013).

- Monitoring Licensees' Compliance with Legislation, FPB/SIR/37 (Victoria: Government of British Columbia, 2013).

- Public Involvement in Forest Management Planning in BC, Board Bulletin Volume 15

(Victoria: Government of British Columbia, 2013).

- A Decade in Review: Observations on Regulation of Forest and Range Practices in British

Columbia, FPB/SR/46 (Victoria: Government of British Columbia, 2014).

Community Watersheds: From Objectives to Results on the Ground, FPB/SIR/40 (Victoria:

Government of British Columbia, 2014).

- Timber Harvesting in Beetle-Affected Areas, FPB/SR/44 (Victoria: Government of British

Columbia, 2014).

Fulton, Fred J. Royal Commission of Inquiry on Timber and Forestry 1909-1910 (Victoria:

Government of British Columbia, 1910).

Joint Land and Resource Forum. Terms of Reference (2008). 
Joint Review Panel for the Mackenzie Gas Project (2005), online CEAA $<$ http://www.ceaa.gc.ca/default.asp?lang=En\&xml=99CDFBEE-2F6F-49BF-99C9$38 \mathrm{AB} 1 \mathrm{FF} 8 \mathrm{C} 281>$.

"Lac-Mégantic runaway train and derailment investigation summary" (2014), online: Transportation Safety Board of Canada <http://www.tsb.gc.ca/eng/rapportsreports/rail/2013/r13do054/r13d0054-r-es.asp>

Nanwakos Council Coastal First Nations \& Lands Natural Resource Operations BC Ministry of Forests. Ecosystem Based Management on BC's Central and North Coast (Great Bear Rainforest) (Victoria: Government of British Columbia, 2012).

National Energy Board. 2014 Annual Report to Parliament (Calgary: Government of Canada, 2015).

National Round Table on the Environment and Economy \& Public Policy Forum. Progress Through Process (Ottawa: Government of Canada, 2012).

Pearse, Peter H. Timber Rights and Forest Policy in British Columbia (Victoria: Royal Commission on Forest Resources, 1976).

- Timber Rights and Forest Policy In British Columbia - Volume 2 (Victoria: Government of British Columbia, 1976).

Priddle, Roland. Federal Public Review of the Moratorium on BC Offshore Oil and Gas Activities: Public Review Panel (Government of Canada, 2003).

Privy Council Office of Canada. A Framework for the Application of Precaution in Science-Based Decision Making About Risk (Ottawa: Government of Canada, 2003).

Sloan, Gordon. The Forest Resources of British Columbia (Victoria: Government of British Columbia, 1945)

—. The Forest Resources of British Columbia (Victoria: Government of British Columbia, 1956).

Timber Tenures in British Columbia (Victoria: Government of British Columbia, 2012), online: Ministry of Forests <https://www.for.gov.bc.ca/ftp/hth/external/!publish/web/timbertenures/timber-tenures-2006.pdf>

United States Environmental Protection Agency. "Oil Cleanup Continues on Kalamazoo River", EPA (June 2013), online: <http://www.epa.gov/enbridgespill/pdfs/enbridge-fs20130624.pdf>.

Yinka Dene Alliance. Save the Fraser Declaration, (2013).

\section{Secondary Materials}

Ackerman, Bruce A. “The Emergency Constitution” (2004) 113 Yale LJ 1029.

Agamben, Giorgio. State of Exception, translated by Kevin Attell (Chicago and London: The University of Chicago Press, 2005).

Allan, TRS. Constitutional Justice: A Liberal Theory of the Rule of Law (Oxford: Claredon Press, 2001).

Arthurs, Harry W. "Rethinking Administrative Law: A Slightly Dicey Business" (1979) 17 OHLJ 1.

Auld, Graeme. Constructing Private Governance: The Rise and Evolution of Forest, Coffee, and Fisheries Certification (New Haven: Yale University Press, 2014).

Auld, Graeme \& Lars H Gulbrandsen. "Transparency in Nonstate Certification: Consequences for Accountability and Legitimacy" (2010) 10 Global Environmental Politics 97. 
Bankes, Nigel. "Shining a Light on the Management of Water Resources: The Role of an Environmental Appeal Board” (2006) 16 JELP 131.

Barstow Magraw, Daniel \& Lisa D Hawke. "Sustainable Development” Daniel Bodansky, Jutta

Brunnee \& Ellen Hey, eds, The Oxford Handbook of International Environmental Law (Oxford: Oxford University Press, 2008) 613.

Beck, Ulrich. Risk Society, translated by Mark Ritter (London: Sage Publications, 1992).

Bell, Stephen \& Andrew Hindmoor. "Governance Without Government? The Case of the Forest

Stewardship Council” (2012) 90 Public Administration 144.

Benidickson, Jamie. Environmental Law (Toronto: Irwin Law, 2009).

—. "The Great Lakes and the Mediterranean Sea: Ecosystem-Management and

Sustainability in the Context of Economic Integration” (2004) 14 JELP 107.

Benidickson, Jamie et al. Practicing Precaution and Adaptive Management: Legal, Institutional and

Procedural Dimensions of Scientific Uncertainty Final Report, (Ottawa: Institute of the

Environment, University of Ottawa, 2005).

Black, Julia. "Proceduralizing Regulation: Part I" (2000) 20 Oxford J Legal Stud 597.

. "Proceduralizing Regulation: Part II" (2001) 21 Oxford J Legal Stud 33.

. "Constructing and Contesting Legitimacy and Accountability in Polycentric Regulatory

Regimes" (2008) 2 Regulation \& Governance 137.

Bodansky, Daniel. "Scientific Uncertainty and the Precautionary Principle” (1991) 33:7

Environment: Science and Policy for Sustainable Development 4.

—. "Deconstructing the Precautionary Principle" David D Caron \& Harry N Scheiber, eds.,

Bringing New Law to Ocean Waters (Leiden: Martinus Nijhoff Publishers, 2004) 381.

Bosselmann, Klaus. The Principle of Sustainability: Transforming Law and Governance, (Aldershot,

Hampshire: Ashgate, 2008).

Boyd, David. "Sustainability Law: (R)Evolutionary Directions for the Future of Environmental

Law” (2004) 14 JELP 357.

. Unnatural Law: Rethinking Canadian Environmental Law and Policy, (Vancouver: UBC

Press, 2003).

- The Right To A Healthy Environment: Revitalizing Canada's Constitution, (Vancouver: UBC

Press, 2012).

Braithwaite, John \& Ian Ayres. Responsive Regulation (Oxford: Oxford University Press, 1992).

Brandes, Oliver M et al. At a Watershed: Ecological Governance and Sustainable Water Management

in Canada (Victoria: POLIS Project on Ecological Governance, 2005).

Buck, Trevor, Richard Kirkham \& Brian Thompson. The Ombudsman Enterprise and

Administrative Justice (Farnham: Ashgate Publishing, 2011).

Cartier, Genevieve. "Le principe de précaution et la déférence judiciare en droit administratif" (2002) 43 Les Cahiers de droit 79.

—. "Procedural Fairness in Legislative Functions: The End of Judicial Abstinence?” (2003)

53 UTLJ 217.

Benjamin Cashore, "Legitimacy and the Privatization of Environmental Governance: How Non-

State Market-Driven (NSMD) Governance Systems Gain Rule-Making Authority" (2002)

15 Governance 503.

Chalifour, Nathalie. "A (Pre) Cautionary Tale About the Kearl Oil Sands Decision: The

Significance of Pembina Institute for Appropriate Development, et al. v. Canada (Attorney-General)

for the Future of Environmental Assessment” (2009) 5 McGill Int'l J Sust Dev L \& Pol'y 251.

Chiasson, Cindy. "Public Access to Environmental Appeals: A Review and Assessment of

Alberta's Environmental Appeals Board” (2007) 17 JELP 141. 
Christie, Gordon. "Indigenous Authority, Canadian Law, and Pipeline Proposals" (2013) 25 JELP 189.

Coglianese, Cary \& David Lazer. "Management- Based Regulation: Prescribing Private Management to Achieve Public Goals” (2003) 37 Law \& Society Review 691.

Coglianese, Cary, Jennifer Nash \& Todd Olmstead. "Performance-Based Regulation: Prospects and Limitations in Health, Safety and Environmental Protection” (2003) 55 Admin L Rev 704.

Cohen, Joshua. "Deliberation and Democratic Legitimacy” In James Bonham \& William Rehg, eds., Deliberative Democracy: Essays on Reason and Politics (Cambridge, Mass: MIT Press, 1997) 67.

Cole, Daniel H. "Judging the Next Emergency: Judicial Review and Individual Rights in Times of Crisis” (2003) 101 Michigan L Rev 2565.

- "The Priority of Morality: The Emergency Constitution's Blind Spot” (2003) 113 Yale LJ 1753.

Collins, Lynda. "Tort, Democracy and Environmental Governance: The Case of NonEnforcement” (2007) 15 Tort L Rev 107.

- "An Ecologically Literate Reading of the Canadian Charter of Rights and Freedoms" (2009) 26 Windsor Rev Legal \& Soc 7.

Cordonier Segger, Marie-Claire \& Ashfaq Khalfan. Sustainable Development Law: Principles, Practices, $\mathcal{E}^{2}$ Prospects (Oxford: Oxford University Press, 2004).

Coyle, Sean \& Karen Morrow. The Philosophical Foundations of Environmental Law: Property, Rights and Nature (Oxford: Hart Publishing, 2004).

Craig, Paul. "Formal and Substantive Conceptions of the Rule of Law" (1997) 3 Public L 467.

- Public Law and Democracy in the United Kingdom and the United States of America (Oxford: Claredon Press, 1990).

Criddle, Evan J. "Mending Holes in the Rule of (Administrative) Law" (2010) 104 Northwestern University Law Review 1271.

Croley, Steven P. “Theories of regulation: Incorporating the administrative process” (1998)

Columbia L Rev 1.

Crutzen, Paul J \& Eugene F Stoermer. "The "Anthropocene” (2000) 41 IGBP Newsletter 17.

Cutting up the Safety Net: Environmental Degradation in British Columbia (West Coast

Environmental Law Association, 2005).

Daly, Paul. "The Scope and Meaning of Reasonableness Review" (2015) 52 Alta L Rev forthcoming.

De Burca, Grainne. "New Governance and Experimentalism: An Introduction” (2010) 2010 Wis L Rev 227.

De Marco, Jerry V \& Paul Muldoon. Environmental Boards and Tribunals in Canada: A Practical Guide (Markham, Ont: LexisNexis Canada, 2011).

Dellert, Lois H. “Sustained Yield: Why Has it Failed to Achieve Sustainability?” In Chris Tollefson, ed., The Wealth of Forests (Vancouver: UBC Press, 1998) 255.

Dershowitz, Alan M. Why Terrorism Works: Understanding the Threat, Responding to the Challenge (New Haven: Yale University Press, 2002).

Dewey, John. The Public and Its Problems (Chicago: The Swallow Press Inc, 1954).

Dicey, A V. An Introduction to the Study of the Law of the Constitution, 10th ed (Toronto:

MacMillan Company of Canada Ltd, 1959).

Doelle, Meinhard. “CEAA 2012: The End of Federal EA As We Know It?” (2013) 24 JELP 1.

Doelle, Meinhard \& Chris Tollefson, eds. Environmental Law Cases and Materials, 2d ed

(Toronto: Carswell, 2013). 
Dorf, Michael C \& Charles F Sabel. “A Constitution of Democratic Experimentalism” (1998)

Columbia L Rev 267.

Dryzek, John S. The Politics of the Earth: Environmental Discourses, 3d ed (Oxford: Oxford

University Press, 2013).

Dupuy, Jean-Pierre. "Complexity and Uncertainty A Prudential Approach to Nanotechnology"

In Health and Consumer Protection Directorate General of the European Commission, ed.,

Nanotechnologies: A Preliminary Risk Analysis on the Basis of a Workshop Organized in Brussels on

1-2 March 2004 (European Commission, 2004) 71.

Dyzenhaus, David. “The Legitimacy of Legality” (1996) 46 UTLJ 129.

. "The Politics of Deference: Judicial Review and Democracy" In Michael Taggart, ed.,

The Province of Administrative Law, (Oxford: Hart Publishing, 1997) 279.

—. "Law as Justification: Etienne Mureinik's Conception of Legal Culture" (1998) 14 S Afr J

on Hum Rts 11.

- “The Permanence of the Temporary - Can Emergency Powers Be Normalized?” In R J

Daniels, P Macklem \& Kent Roach, eds., The Security of Freedom: Essays on Canada's Anti-

Terrorism Bill (Toronto: University of Toronto Press, 2001) 21.

—. "Constituting the Rule of Law: Fundamental Values in Administrative Law" (2002) 27

Queen's LJ 445.

- The Constitution of Law: Legality in a Time of Emergency (Cambridge: Cambridge

University Press, 2006).

—. "Cycles of Legality in Emergency Times" (2007) 18 Public L Rev 165.

- "Accountability and the Concept of (Global) Administrative Law" (2009) 2009 Acta

Juridica 3.

—. "Emergency, Liberalism, and the State" (2011) 9 Perspectives on Politics 69.

—. "Preventive Justice and the Rule-of-Law Project" In Andrew Ashworth, Lucia Zedner \&

Patrick Tomlin, eds., Prevention and the Limits of the Criminal Law (Oxford: Oxford

University Press, 2013).

Dyzenhaus, David \& Evan Fox-Decent. "Rethinking the Process/Substance Distinction: Baker v.

Canada" (2001) 51 UTLJ 193.

Edgar, Andrew. "Procedural Fairness for Decisions Affecting the Public Generally: A Radical

Step towards Public Consultation?” (2014) 33 Univ Tas L Rev 56.

Edmundson, William A. "State of the Art: The Duty of Obey the Law" (2004) 10 Legal Theory

215.

Ellis, Jaye. "Overexploitation of a Valuable Resource? New Literature on the Precautionary

Principle” (2006) 17 European J of Int'l L 445.

Ellis, Ron. Unjust by Design: Canada's Administrative Justice System (Vancouver: UBC Press, 2013).

Emond, D Paul. "The Greening of Environmental Law" (1990) 36 McGill LJ 742.

- “'Are We There Yet?' Reflections on the Success of the Environmental Law Movement in Ontario” (2008) 46 Osgoode Hall LJ 219.

Farber, Daniel A. "Probabilities Behaving Badly: Complexity Theory and Environmental

Uncertainty” (2003) 37 UC Davis L Rev 145.

Fatovic, Clement. Outside the Law: Emergency and Executive Power (Baltimore: John Hopkins

University Press, 2009).

Ferejohn, John \& Pasquale Pasquino. "The Law of Exception: A Typology of Emergency

Powers" (2004) 2 Int'l J Const L 210.

Ferguson, Alex. "Challenges and Solutions - An Industry Perspective” In Terry L Shore, J E

Brooks \& J E Stone, eds., Mountain Pine Beetle Symposium: Challenges and Solutions October 30-

312003 (Pacific Forestry Centre, 2003). 
Findlay, C Scott et al. "Sustainability Lost: Comments on 'Planning for a Sustainable Future: A Federal Sustainable Development Strategy for Canada” (2010) 22 JELP 77.

Fischer, Frank. "Environmental Regulation and Risk-Benefit Analysis: From Technical to Deliberative Policy Making” In R Paehlke \& D Torgerson, eds., Managing Leviathan: Environmental Politics and the Administrative State, 2d ed (Peterborough, Ont: Broadview Press, 2005) 59.

Fisher, Douglas E. Australian Environmental Law: Norms, Principles and Rules, 3d ed (Pyrmont, NSW: Thomson Reuters, 2014).

Fisher, Elizabeth. "Review: Laws of Fear: Beyond the Precautionary Principle" (2006) Modern L Rev 288.

- Risk Regulation and Administrative Constitutionalism (Oxford and Portland OR: Hart Publishing, 2007).

—. "Food Safety Crises as Crises in Administrative Constitutionalism" (2010) 20 Health Matrix 55.

Fisher, Elizabeth \& Ronnie Harding. "The Precautionary Principle and Administrative Constitutionalism: The Development of Frameworks for Applying the Precautionary Principle” In Elizabeth Fisher, Judith Jones \& René von Schomberg, eds., Implementing the Precautionary Principle: Perspectives and Prospects (Edward Elgar Pub, 2006) 113.

Fisher, Elizabeth et al. "Maturity and Methodology: Starting a Debate about Environmental Law Scholarship” (2009) 21 JEL 213.

Elizabeth Fisher, "Environmental Law as 'Hot' Law” (2013) 25 JEL 347.

Fluker, Shaun. "Protecting Alberta's Environment Act: A Keystone Kops Response to

Environmental Monitoring and Reporting in Alberta" (2014) ABLawg, online:

<http://ablawg.ca/2014/01/02/protecting-albertas-environment-act-a-keystone-kopsresponse-to-environmental-monitoring-and-reporting-in-alberta/ $>$.

Fluker, Shaun \& Jocelyn Stacey. "The Basics of Species at Risk Legislation in Alberta" (2012) 50 Alta L Rev 95.

Forcese, Craig \& Kent Roach. "Stumbling Toward Total Information Awareness: The Security of Canada Information Sharing Act” (2015) 12 Can Privacy L Rev 65.

Ford, Cristie. "New Governance in the Teeth of Human Frailty: Lessons from Financial Regulation” (2010) 2010 Wis L Rev 441.

- "Dogs and Tails: Remedies in Administrative Law" In Lorne Sossin \& Colleen Flood, eds., Administrative Law in Context, 2 d ed (Emond Montgomery Publications Ltd, 2013$) 85$.

Forst, Rainer. The Right to Justification: Elements of a Constructivist Theory of Justice, translated by Jeffrey Flynn (New York: Columbia University Press, 2011).

Fox-Decent, Evan. Sovereignty's Promise: The State as Fiduciary (Oxford, New York: Oxford University Press, 2011).

Freeman, Jody. "The Private Role in the Public Governance" (2000) 75 NYUL Rev 543. Freeman, Jody \& Daniel A Farber. "Modular Environmental Regulation” (2005) Duke L J 795. Fuller, Lon L. The Morality of Law, rev ed (New Haven, CT: Yale University Press, 1969).

- "Forms and Limits of Adjudication" In Kenneth I Winston, ed., The Principles of Social Order: Selected Essays of Lon L Fuller, revised ed (Oxford - Portland, OR: Hart Publishing, 2001) 101.

. "Means and Ends" In Kenneth I Winston, ed., The Principles of Social Order: Selected Essays of Lon L Fuller, rev ed (Oxford \& Portland: Hart Publishing, 2001) 61.

Gallie, W B. "Essentially Contested Concepts" (1955) 56 Proceedings of the Aristotelian Society 167. 
Gibson, Robert B. "Beyond the Pillars: Sustainability Assessment as a Framework for Effective Integration of Social, Economic and Ecological Considerations in Significant DecisionMaking" (2006) 8 J of Envtl Assessment Pol'cy \& Mgmt 259.

Giddens, Anthony. The Politics of Climate Change, 2d ed (Cambridge: Polity Press, 2011).

Godard, Olivier. "The Precautionary Principle and Catastrophism on Tenterhooks: Lessons From a Constitutional Reform in France” In Elizabeth Fisher, Judith Jones \& René von Schomberg, eds., Implementing the Precautionary Principle: Perspectives and Prospects (Cheltenham, UK: Edward Elgar Pub, 2006) 63.

Green, Andrew. "Regulations and Rule Making: The Dilemma of Delegation” In Colleen Flood \& Lorne Sossin, eds., Administrative Law in Context, 2d ed (Toronto: Emond Montgomery Publications Ltd, 2013) 125.

Gross, Oren. "Chaos and Rules: Should Responses to Violent Crises Always Be Constitutional?" (2003) 112 Yale LJ 1011.

—. "Extra-legality and the ethic of political responsibility" In V V Ramraj, ed., Emergencies and the Limits of Legality (Cambridge: Cambridge Univ Press, 2008) 60.

Gross, Oren \& Fionnuala N Aolain. Law in Times of Crisis (New York: Cambridge University Press, 2006).

Gunningham, Neil. "Environment Law, Regulation and Governance: Shifting Architectures" (2009) 21 JEL 179.

Gunningham, Neil, Peter Grabosky \& Darren Sinclair. Smart Regulation: Designing Environmental Policy (Oxford: Claredon Press, 1998).

Gutmann, Amy \& Dennis Thompson. Why Deliberative Democracy? (Princeton: Princeton University Press, 2004).

Habermas, Jürgen. Between Facts and Norms, translated by William Rehg (Cambridge: MIT Press, 1996).

Haddock, Mark. Environmental Tribunals in British Columbia (Victoria: Environmental Law Centre, University of Victoria, 2011).

Hania, Patricia. "Climate Change and the Protection of Drinking Water in Ontario: An Opportunity to Adopt Adaptive Management?” (2011) 22 JELP 167.

Heinzerling, Lisa. "Pragmatists and Environmentalists" (2000) 113 Harv L Rev 1421.

—. "The Environment” In Peter Cane \& Mark Tushnet, eds., The Oxford Handbook of Legal Studies (Oxford: Oxford University Press, 2003) 701.

Holder, Jane. "New Age: Rediscovering Natural Law” (2000) 53 CLP 151.

Holley, Cameron \& Neil Gunningham. "Natural Resources, New Governance and Legal

Regulation: When Does Collaboration Work?” (2011) 24 NZ Univ L Rev 309.

Holling, Crawford S. "Resilience and Stability of Ecological Systems" (1973) 4 Ann Rev of Ecology and Systematics 1.

Honig, Bonnie. Emergency Politics: Paradox, Law, Democracy (Princeton: Princeton University Press, 2009).

Howlett, Michael, Jeremy Rayner \& Chris Tollefson. "From Government to Governance in Forest Planning? Lessons From the Case of the British Columbia Great Bear Rainforest Initiative" (2009) 11 Forest Policy and Economics 383.

Hughes, Elaine L. "Fishwives and Other Tails: Ecofeminism and Environmental Law" (1995) 8 CJWL 502.

Huscroft, Grant. "From Natural Justice to Fairness: Thresholds, Content, and the Role of Judicial Review” In Colleen Flood \& Lorne Sossin, eds., Administrative Law in Context, 2d ed (Toronto: Emond Montgomery Publications Ltd, 2012) 147. 
Jacobs, Laverne. “Tribunal Independence and Impartiality: Rethinking the Theory after Bell and Ocean Port Hotel -- A Call for Empirical Analysis” In Laverne Jacobs \& Anne L Mactavish, eds., Dialogue Between Courts and Tribunals - Essays in Administrative Law and Justice (20012007) (Montreal: Les Editions Themis, 2008) 43.

Jasanoff, Sheila. The Fifth Branch: Science Advisors as Policymakers (Cambridge, Mass: Harvard University Press, 1990).

—. "A Living Legacy: The Precautionary Ideal in American Law” In J A Tickner, ed., Precaution: Environmental Science and Preventive Public Policy (Washington DC: Island Press, 2003) 227.

Jones, Judith \& Simon Bronitt. "The Burden and Standard of Proof in Environmental

Regulation: the Precautionary Principle in an Australian Administrative Context” In Elizabeth Fisher \& Judith Jones, eds., Implementing the Precautionary Principle: Perspectives and Prospects (Cheltenhem, UK: Edward Elgar Pub, 2006) 137.

Jowell, Jeffrey. "The Democratic Necessity of Administrative Justice” (2006) Acta Juridica 13. Karkkainen, Bradley C. "Collaborative Ecosystem Governance: Scale, Complexity, and Dynamism” (2002) 21 Va Envtl LJ 189.

- "Information-forcing Regulation and Environmental Governance" In Grainne De Burca \& Joanne Scott, eds., Law and New Governance in the EU and the US, ed (Portland, OR: Hart Publishing, 2006) 293.

—. “New Governance' in the Great Lakes: Has Its Time Arrived?” (2006) 2006 Mich St L Rev 1249.

Kingsbury, Benedict, Richard B Stewart \& Nico Krisch. “The Emergence of Global

Administrative Law” (2005) 68 Law \& Contemporary Problems 15.

Keyes, John M. Executive Legislation, 2d ed (Toronto: LexisNexis Canada, 2010).

Kong, Hoi. "Election Law and Deliberative Democracy: Against Deflation" (2015) 9 JPPL 35.

Kysar, Douglas A. "Climate Change, Cultural Transformation, and Comprehensive Rationality" (2004) 31 BC Envtl Aff L Rev 555.

—. "It Might Have Been: Risk, Precaution and Opportunity Costs" (2006) 22 J Land Use \& Envtl L 1 .

- Regulating from Nowhere: Environmental Law and the Search for Objectivity (New Haven, CT: Yale University Press, 2010).

Lafferty, William M. "The Politics of Sustainable Development: Global Norms for National Implementation” (1996) 5 Environmental Politics 185.

Lahey, William \& Meinhard Doelle. "Negotiating the Interface of Environmental and Economic Governance: Nova Scotia's Environmental Goals and Sustainable Prosperity Act” (2012) 35 Dal L J 1.

Landis, James M. The Administrative Process (New Haven: Yale University Press, 1938).

Lazar, Nomi C. States of Emergency in Liberal Democracies (New York: Cambridge University Press, 2009).

Lazarus, Richard J. "Super Wicked Problems and Climate Change: Restraining the Present to Liberate the Future" (2009) 94 Cornell L Rev 1153.

Leckey, Robert. Contextual Subjects: Family, State, and Relational Theory (Toronto: University of Toronto Press, 2008).

Lee, Marilyn G. "How Tribunals and Appeal Boards are Contributing to Advances in

Environmental Laws” (2014) 26 JELP 249.

Legal Backgrounder: The National Energy Board Act 1985 (Toronto: EcoJustice, 2012).

Levinson, Sanford. "Constitutional Norms in a State of Permanent Emergency” (2005) 40 Ga L

Rev 699. 
Lewans, Matthew. "Deference and Reasonableness Since Dunsmuir” (2012) 38 Queen's LJ 59.

Liston, Mary. "Evolving Capacities: The BC Representative for Children and Youth as a Hybrid

Model of Oversight" Laverne Jacobs, Sasha Baglay eds, The Nature of Inquisitorial Processes in Administrative Regimes (Aldershot: Ashgate Publishing, 2013).

Lobel, Orly. "The Renew Deal: The Fall of Regulation and the Rise of Governance in

Contemporary Legal Thought" (2004) 89 Minn L Rev 342.

Locke, John. Two Treatises of Government (London, 1764).

Loughlin, Martin. "Procedural fairness: A Study of the Crisis in Administrative Law Theory" (1978) 28 UTLJ 215.

Lowe, Vaughn. "Sustainable Development and Unsustainable Arguments" In A Boyle \& D

Freestone, eds., International Law and Sustainable Development: Past Achievements and Future

Challenges (Oxford: Oxford University Press, 1999) 19.

Lyon, J N. "Constitutional Validity of Sections 3 and 4 of the Public Order Regulations, 1970"

(1972) 18 McGill LJ 136.

M'Gonigle, Michael \& Paula Ramsey. "Greening Environmental Law: From Sectoral Reform to Systemic Re-Formation” (2004) 14 JELP 333.

MacLean, Jason. "No Deference Without Independence: Ernst v Alberta (Energy Resources Conservation Board)" (2014) Toronto L J.

MacLean, Jason, Meinhard Doelle \& Chris Tollefson. "The Past, Present and Future of Canadian Environmental Law: A Critical Dialogue” (2015) Lakehead LJ forthcoming.

Marx, Axel \& Dieter Cuypers. "Forest Certification as a Global Environmental Governance

Tool: What Is the Macro- Effectiveness of the Forest Stewardship Council?” (2010) 4

Regulation \& Governance 408.

Marx, Herbert. "The Apprehended Insurrection of October 1970 and the Judicial Function" (1972) 7 UBCL Rev 55.

Mashaw, Jerry L. "Accountability and Institutional Design: Some Thoughts on the Grammar of Governance” In Michael Dowdle, ed., Public Accountability: Designs, Dilemmas and Experiences (Cambridge: Cambridge Univ Press, 2006) 115.

McCormick, John P. "The Dilemma of Dictatorship: Carl Schmitt and Constitutional Emergency Powers" In David Dyzenhaus, ed., Law as Politics: Carl Schmitt's Critique of Liberalism (Durham \& London: Duke University Press, 1998) 217.

McDonald, Leighton. "The Rule of Law in the 'New Regulatory State” (2004) 33 Common Law World Review 197.

McGarrity, Kim \& George Hoberg. "The Beetle Challenge: an Overview of the Mountain Pine Beetle Epidemic and Its Implications” (2005) Forest Policy Resources, University of British Columbia.

McGee, Gordon, Andrea Cullen \& Thomas Gunton. “A New Model for Sustainable

Development: A Case Study of the Great Bear Rainforest Regional Plan” (2010) 12 Environ Dev Sustain 745 .

McLean, Jason, Meinhard Doelle \& Chris Tollefson. "The Past, Present and Future of Canadian Environmental Law: A Critical Dialogue” (2015) Lakehead LJ forthcoming.

McLeod-Kilmurray, Heather \& G Smith. "Unsustainable Development in Canada:

Environmental Assessment, Cost-Benefit Analysis, and Environmental Justice in the Tar Sands" (2010) 21 JELP 65.

Meidinger, Errol. "The Administrative Law of Global Private-Public Regulation: the Case of Forestry” (2006) 17 Euro J of Int'l L 47. 
Mickelson, Karin \& William E Rees. “The Environment: Ecological and Ethical Dimensions” In Elaine L Hughes, A R Lucas \& William A Tilleman, eds., Environmental Law and Policy, 3d ed (Toronto: Emond Montgomery Publications Ltd, 2003) 1.

Mullan, David J. “Judicial Review of Executive Decision-making: Evolving Concepts of Responsibility” (1993) 19 Queen's L J 137.

Nelson, Harry. "Does a Crisis Matter? Forest Policy Responses to the Mountain Pine Beetle Epidemic in British Columbia” (2007) 55 Can J of Ag Econ 459.

Nikiforuk, Andrew. Empire of the Beetle (Vancouver: Greystone Books, 2011).

Nowlan, Linda. "CPR for Canadian Rivers -- Law to Conserve, Protect, and Restore

Environmental Flows in Canada” (2012) 23 JELP 237.

Olszynski, Martin. "Environmental Monitoring and Ecosystem Management in the Oil Sands: Spaceship Earth or Escort Tugboat?” (2014) 10 McGill Int'l J Sust Dev L \& Pol'y 1.

Orts, Eric W. "Reflexive Environmental Law” (1995) 89 Nw UL Rev 1227.

Overdest, Christine \& Jonathan Zeitlin. "Assembling an Experimentalist Regime: Transnational Governance Interactions in the Forest Sector" (2014) 8 Regulation \& Governance 22.

Pardy, Bruce. "Abstraction, Precedent, and Articulate Consistency: Making Environmental Decisions” (1998) 34 Cal Western L Rev 427.

—. "Environmental Law and the Paradox of Ecological Citizenship: The Case for Environmental Libertarianism” (2005) 33 Environments 25.

- "In Search of the Holy Grail of Environmental Law: A Rule to Solve the Problem" (2005) 1 McGill Int'l J Sust Dev L \& Pol'y 29.

- "Ecosystem Management in Question: A Reply to Ruhl” (2006) 23 Pace Envtl L Rev 209.

— "The Pardy-Ruhl Dialogue on Ecosystem Management Part V: Discretion, ComplexAdaptive Problem Solving and the Rule of Law” (2008) 25 Pace Envtl L Rev 341.

- "Environmental Assessment and Three Ways Not to Do Environmental Law" (2010) 21 JELP 139.

Pardy, Bruce \& Annette Stoehr. "The Failed Reform of Ontario's Mining Laws" (2012) 23 JELP 1 .

Parfitt, Ben. Battling the Beetle: Taking Action to Restore British Columbia's Interior Forests, ed (Vancouver: Canadian Centre for Policy Alternatives, 2005).

Parkinson, John \& Jane Mansbridge. Deliberative Systems: Deliberative Democracy at the Large Scale (Cambridge: Cambridge University Press, 2012).

Peel, A L. The Future of Our Forests (Victoria: Forest Resources Commission, 1991).

Peel, Jacqueline. The Precautionary Principle in Practice (Annandale NSW: The Federation Press, 2005).

Pedersen, Larry. "Allowable Annual Cuts in British Columbia: The Agony and the Ecstasy" (Jubilee Lecture at the UBC Faculty of Forestry, March, 2003), online: British Columbia Ministry of Forestry <http://www.for.gov.bc.ca/hts/pubs/jubilee_ubc.pdf $>$ [unpublished].

Pettit, Philip. Republicanism: A Theory of Freedom and Government (Oxford: Oxford University Press, 1999).

Philippopoulos-Mihalopoulos, Andreas. "Looking for the Space Between Law and Ecology” In A Philippopoulos-Mihalopoulos, ed, Law and Ecology: New Environmental Foundations (London: Routledge, 2011) 1.

Poole, Thomas. "Constitutional Exceptionalism and the Common Law" (2009) 7 Int'l J Const L 247.

Posner, Eric A \& Adrian Vermeule. “Accommodating Emergencies” (2003) Stanford Law Review 605. 
- The Executive Unbound (Oxford: Oxford University Press, 2010).

Pousette, John \& Chris Hawkins. "An Assessment of Critical Assumptions Supporting the

Timber Supply Modelling for Mountain-Pine-Beetle-Induced Allowable Annual Cut Uplift

in the Prince George Timber Supply Area” (2006) 7 J Ecosystems \& Management 93.

Price, Karen, Audrey Roburn \& Andy MacKinnon. "Ecosystem-Based Management in the Great

Bear Rainforest" (2009) 258 Forest Ecology and Management 495.

Raitio, Kaisa \& Heli Saarikoski. "Governing Old-Growth Forests: The Interdependence of

Actors in Great Bear Rainforest in British Columbia” (2012) 25 Society \& Natural

Resources: An International Journal 900.

Rhodes, RAW. “The New Governance: Governing without Government” (1996) 44 Political

Studies 652.

Richardson, Benjamin J \& Stepan Wood. "Environmental Law for Sustainability” In Benjamin J

Richardson \& Stepan Wood, eds., Environmental Law for Sustainability (Oxford and Portland:

Hart Publishing, 2006) 1.

Richardson, Henry S. Democratic Autonomy: Public Reasoning About the Ends of Policy (Oxford:

Oxford University Press, 2002).

Roach, Kent. The 9/11 Effect: Comparative Counter-Terrorism (Cambridge: Cambridge University

Press, 2011).

Ross, Andrea. "Modern Interpretations of Sustainable Development” (2009) 36 J L \& Soc'y 32.

Rossiter, Clinton. Constitutional Dictatorship: Crisis Government in the Modern Democracies (New

Brunswick: Transaction Publishers, 2002).

Ruhl, J.B. “The Pardy-Ruhl Dialogue on Ecosystem Management, Part IV: Narrowing and

Sharpening the Questions" (2007) 24 Pace Envtl L Rev 25.

Rundle, Kristen. Forms Liberate: Reclaiming the Jurisprudence of Lon L Fuller (Oxford and

Portland: Hart Publishing, 2012).

Sabel, Charles F \& Jonathan Zeitlin. "Learning from Difference: The New Architecture of

Experimentalist Governance in the EU” (2008) 14 European L J 271.

Sabel, Charles F \& William H Simon. "Epilogue: Accountability Without Sovereignty” In

Grainne De Burca \& Joanne Scott, eds., Law and New Governance in the EU and the US (Hart

Publishing, 2006) 395.

—. "Due Process of Administration: The Problem of Police Accountability" (2014) Stanford

Public Law Working Paper, online: SSRN

$<$ http://papers.ssrn.com/sol3/papers.cfm?abstract_id=2507280 >.

Salamon, Lester M. “The New Governance and the Tools of Public Action: An Introduction” In

Lester M Salamon, ed., The Tools of Government: A Guide to the New Governance (Oxford:

Oxford University Press, 2002) 1.

Scheppele, Kim Lane. "Small Emergencies” (2005) 40 Ga L Rev 835.

Scheuerman, William E. "Carl Schmitt's Critique of Liberal Constitutionalism” (1996) 58 The

Review of Politics 299.

—. "The Economic State of Emergency" (2000) 21 Cardozo L Rev 1869.

—. "Survey Article: Emergency Powers and the Rule of Law After 9/11" (2006) 14 Journal of Political Philosophy 61.

- "Emergencies, Executive Power, and the Uncertain Future of US Presidential

Democracy" (2012) 37 Law \& Social Inquiry 743.

Schmitt, Carl. Political Theology, translated by G Schwab (Cambridge, Mass: MIT Press, 1985).

Scott, Dayna Nadine. "When Precaution Points Two Ways: Confronting 'West Nile Fever"

(2005) 20 Can JL \& Soc 27. 
—. "Situating Sarnia: 'Unimagined Communities' in the New National Energy Debate” (2013) 25 JELP 81.

Scott, Joanne \& Susan Sturm. “Courts as Catalysts: Re-Thinking the Judicial Role in New Governance” (2006) 13 Colum J Eur L 565.

Seidenfeld, Mark. "The Role of Politics in a Deliberative Model of the Administrative State" (2013) 81 George Washington Law Review 1397.

Shapiro, Martin. "Administrative Law Unbounded: Reflections on Government and Governance” (2000) 8 Ind J Global Legal Stud 369.

Simmonds, Nigel E. Law as a Moral Idea (Oxford: Oxford University Press, 2007).

Simon, William H. "Toyota Jurisprudence: Legal Theory and Rolling Rule Regimes" In Grainne

De Burca \& Joanne Scott, eds., Law and New Governance in the US and the EU (Portland, OR: Hart Publishing, 2006) 37.

Smith, Merran \& Darcy Dobell. Place of Power: Lessons from the Great Bear Rainforest (Vancouver: Tides Canada Foundation, 2010).

Sossin, Lorne. "The Uneasy Relationship between Independence and Appointments in Canadian Administrative Law” In G Huscroft \& Michael Taggart, eds., Inside and Outside Canadian Administrative Law: Essays in Honour of David Mullan (Toronto: University of Toronto Press, 2006) 50.

- "The Unfinished Project of Roncarelli v. Duplessis: Justiciability, Discretion, and the Limits of the Rule of Law” (2010) 55 McGill LJ 661.

Stacey, Jocelyn. "The Rule-of-Law Underpinnings of Endangered Species Protection: Minister of Fisheries and Oceans v David Suzuki Foundation, 2012 FCA 40" (2014) 27 JELP 57.

- "The Public Law of Private Governance: Assessing the Forest Stewardship Council" (paper presented at the Australia \& New Zealand Law \& Society Association Conference, 2014) [unpublished].

Steele, Jenny. "Participation and Deliberation in Environmental Law: Exploring a Problemsolving Approach” (2001) 21 Oxford Journal of Legal Studies 415.

Stephenson, N L et al. "Rate of Tree Carbon Accumulation Increases Continuously with Tree Size” (2014) 507 Nature 90.

Stewart, Richard B. "The Reformation of American Administrative Law" (1975) Harvard Law Review 1667.

Sunstein, Cass R. Designing Democracy: What Constitutions Do (Oxford: Oxford University Press, 2001).

- Risk and Reason: Safety, Law, and the Environment (Cambridge: Cambridge University Press, 2002).

—. Laws of Fear (Cambridge: Cambridge University Press, 2005).

—. "On the Divergent American Reactions to Terrorism and Climate Change" (2007) 107 Colum L Rev 503.

Tarlock, A Dan. "Is There a There There in Environmental Law" (2003) 19 J Land Use \& Envtl L 213.

Teubner, Gunther. "Substantive and Reflexive Elements in Modern Law” (1983) 17 Law \& Soc Rev 239.

Tilleman, William A. "Environmental Appeal Boards: A Comparative Look at the United States, Canada and England” (1996) 21 Colum J Envtl L 1.

Tirone, Susan, Karen Gallant \& Katie Sykes. "Environmental Goals and Sustainable Prosperity Act And the People of the Province: EGSPA's Social Deficit” (2012) 35 Dal L J 71.

Tollefson, Chris, Fred P Gale \& David Haley. Setting the Standard: Certification, Governance and the Forest Stewardship Council (Vancouver: UBC Press, 2008). 
Tollefson, Chris \& Jamie Thornback. "Litigating the Precautionary Principle in Domestic Courts" (2008) 19 JELP 33.

Tollefson, Chris, Anthony R Zito \& Fred P Gale. "Symposium Overview: Conceptualizing New Governance Arrangements” (2012) 90 Public Administration 3.

Trubek, David \& Louise Trubek. "World Turned upside Down: Reflections on New Governance and the Transformation of Law, The" (2010) Wis L Rev 719.

—. "New Governance \& Legal Regulation: Complementarity, Rivalry, and Transformation" (2007) 13 Columbia Journal of European Law 539.

Tushnet, Mark. "Emergencies and the Idea of Constitutionalism” In Mark Tushnet, ed., The Constitution in Wartime (Durham \& London: Duke University Press, 2005) 39.

Underdal, Arild. "Complexity and Challenges of Long-Term Environmental Governance" (2010) 20 Global Environmental Change 386.

Utzig, G F \& D L Macdonald. Citizens' Guide to Allowable Annual Cut Determinations (BC Environmental Network Educational Foundation, 2000).

VanderZwaag, David L. "The Precautionary Principle in Environmental Law and Policy:

Elusive Rhetoric and First Embraces" (1998) 8 JELP 355.

Viñuales, Jorge E. "The Rise and Fall of Sustainable Development" (2013) 22 RECIEL 3.

Voigt, Christina. Sustainable Development as a Principle of International Law (Leiden: Martinus Nijhoff Publishers, 2009).

Waldron, Jeremy. "Is the Rule of Law an Essentially Contested Concept (in Florida)?" (2002) 21 Law \& Phil 137.

Walter, Emily. "From Civil Disobedience to Obedient Consumerism? Influences of Marketbased Activism and Eco-certification on Forest Governance" (2003) 41 Osgoode Hall L J 531.

—. "Decoding Codes of Practice: Approaches to Regulating the Ecological Impacts of Logging in British Columbia” (2005) 15 JELP 143.

Walters, Mark D. "The Common Law Constitution in Canada: Return of lex non scripta as fundamental law" (2001) 51 UTLJ 91.

- "Dicey on Writing the Law of the Constitution" (2012) 32 Oxford J Legal Stud 21.

Warren, Mark E \& Hilary Pearse. Designing Deliberative Democracy: The British Columbia Citizens' Assembly (Cambridge: Cambridge University Press, 2008).

Whitaker, Reg. "Keeping Up with the Neighbours? Canadian Responses to 9/11 in Historical and Comparative Context" (2003) 41 Osgoode Hall LJ 241.

Whitehead, Roger J, Lee Safranyik \& Terry L Shore. "Preventative Management” In Lee Safranyik \& Bill Wilson, eds., Mountain Pine Beetle: A Synthesis of Biology, Management and Impacts on Lodgepole Pine (Victoria: Pacific Forestry Centre, 2006) 173.

Whiteside, Kerry H. Precautionary Politics: Principle and Practice in Confronting Environmental Risk (Cambridge, Mass: MIT Press, 2006).

Wiersema, Annecoos. "A Train without Tracks: Rethinking the Place of Law and Goals in Environmental and Natural Resources Law” (2008) 38 Envtl L 1239.

Wilkinson, Michael. "Three Conceptions of Law: Towards a Jurisprudence of Democratic Experimentalism” (2010) 2010 Wisc L Rev 673.

Williams, Julie. "The Design of Performance-Based Natural Resource Regulation: Lessons from the B.C. Experience" (2005) 18 CJALP 61.

Willis, John. "Three Approaches to Administrative Law: The Judicial, the Conceptual, and the Functional” (1935) 1 UTLJ 53. 
Wilson, Bill. “An Overview of the Mountain Pine Beetle Initiative” In Terry L Shore, J E Brooks \& J E Stone, eds., Mountain Pine Beetle Symposium: Challenges and Solutions (Kelowna: Natural Resources Canada, 2003) 3.

Winfield, Mark S. "Governance and the Environment in Canada From Regulatory Renaissance to 'Smart Regulation”" (2007) 17 JELP 69.

Wood, Mary Christina. ""You Can’t Negotiate with a Beetle:” Environmental Law for a New Ecological Age” (2010) 50:1 Natural Resources Journal 167.

Wood, Stepan. "Environmental Management Systems and Public Authority in Canada: Rethinking Environmental Governance” (2002) 10 Buff Envtl LJ 129.

Wood, Stepan, Georgia Tanner \& Benjamin J Richardson. "What Ever Happened to Canadian Environmental Law?” (2011) 37 Ecology L Q 981.

Alice Woolley, "Legitimating Public Policy" (2008) 58 UTLJ 153.

World Commission on Environment and Development. Our Common Future, (Oxford: Oxford University Press, 1987).

Wynne, Brian. "Uncertainty and Environmental Learning” (1992) 2 Global Environmental Change 111.

— "May the Sheep Safely Graze? A Reflexive View of the Expert-Lay Knowledge Divide" In Scott Lash, Bronislaw Szerszynski \& Brian Wynne, eds., Risk, Environment and Modernity: Towards a New Ecology (London: SAGE Publications, 1998) 44.

Zuckerman, Ian. "One Law for War and Peace? Judicial Review and Emergency Powers between the Norm and the Exception” (2006) 13 Constellations 522.

\section{Newspaper Articles and Online Resources}

Alberta Health Services, News Release "Cancer Incidence in Fort Chipewyan Follow-Up Report”(24 March 2014), online: <http://www.albertahealthservices.ca/poph/hi-poph-survcancer-overview-fort-chip-2014-03-24.pdf $>$.

"An open letter from Natural Resources Minister Joe Oliver" (9 January 2012) The Globe and Mail, online: The Globe and Mail <http://www.theglobeandmail.com/news/politics/anopen-letter-from-natural-resources-minister-joe-oliver/article4085663/>.

Commission for Environmental Cooperation: <http://www.cec.org/>.

Commissioner of the Environment and Sustainable Development: Online: Office of the Auditor General of Canada <http://www.oag-bvg.gc.ca/internet/English/cesd_fs_e_921.html>.

“Discretionary Decisions” online: Forest Practices Board <http://www.bcfpb.ca/board/policies/complaint-investigations/discretionary-decisions >.

Dyer, Clare. "Terror QC: More Will Quit Special Court” The Guardian (20 December 2004), online: The Guardian <http://www.theguardian.com/politics/2004/dec/20/terrorism.humanrights $>$.

The Earth Charter, online: The Earth Charter Initiative <http://www.earthcharterinaction.org/content/pages/Read-the-Charter.html>.

Eliesen, Marc. "View: Energy executive blasts Kind Morgan review as 'fraudulent,' quits" The Tyee (3 November 2014), online: The Tyee <http://thetyee.ca/Blogs/TheHook/2014/11/03/VIEW-energy-exec-blasts-KinderMorgan-quits/>.

"Energy East Process", online: NEB <https://www.nebone.gc.ca/pplctnflng/mjrpp/nrgyst/index-eng.html>. 
"Environmental and Human Health Implications of Athabasca Oil Sands" One River News (July 2014), online: One River News <http://onerivernews.ca/health-study-press-release-2014/>.

"Environmental Organizations Welcome Province and First Nations Great Bear Rainforest

Commitments" (31 March 2014), online: Save the Great Bear

$<$ http://www.savethegreatbear.org/>.

FSC-Watch, online: FSC-Watch <http://www.fsc-watch.org/>.

Inkley, Doug, John Kostyack \& Sterling Miller. “Tar Sands Development to Lead to Poisoning of Wolves" National Wildlife Federation (2 June 2012), online: NWF

<https://www.nwf.org/News-and-Magazines/Media-Center/News-by-

Topic/Wildlife/2012/02-06-12-Tar-Sands-Development-to-Lead-to-Poisoning-of-

Wolves.aspx $>$.

McCarthy, Shawn. "CSIS, RCMP monitored activist groups before Northern Gateway hearings" The Globe and Mail (21 November 2013), online: The Globe and Mail <http://www.theglobeandmail.com/report-on-business/industry-news/energy-andresources/csis-rcmp-monitored-activists-for-risk-before-enbridgehearings/article $15555935 />$.

Memorandum of Fact and Law of the applicant Federation of British Columbia Naturalists carrying on business as BC Nature (22 May 2015) [copy on file with author].

Morello, Loren \& Climate Wire. "Polar Ice Sheets Melting Faster than Predicted" Scientific American (March 2011).

National Energy Board, Press Release "NEB Chair's Cross-Country Engagement begins Monday in Atlantic Canada” (25 January 2015), online: NEB < https://www.nebone.gc.ca/bts/nws/nr/2015/nro4-eng.html>.

"National Energy Board's impartiality over pipeline decisions questioned (5 November 2014)"

Canadian Broadcasting Corporation (November 2015), online: CBC News <http://www.cbc.ca/m/touch/canada/newbrunswick/story/1.2824507>.

"Ontario Source Protection Overview", online: Ontario Government $<$ https://www.ontario.ca/environment-and-energy/source-protection>.

"PM dumps citizens' assembly on climate change" The Australian (7 October 2010), online: The Australian <http://www.theaustralian.com.au/national-affairs/climate/pm-dumps-citizensassembly-on-climate-change/story-e6frg6xf-1225935582575>.

Pearse, Fred. "UN Climate Report is Cautious on Making Specific Predictions" Yale Environment 360 (24 March 2014), online: Yale Environment 360

$<$ http://e360.yale.edu/feature/un_climate_report_is_cautious_on_making_specific_predicti ons $/ 2750 />$.

Pembina Institute. “Oilsands 101: Climate Impacts”, online: Pembina <http://www.pembina.org/oil-sands/os101/climate>.

Pembina Institute. “Oilsands 101: Tailings”, online: Pembina <http://www.pembina.org/oilsands/os 101/tailings>.

Pembina Institute. "Oilsands 101: Water Impacts”, online: Pembina <http://www.pembina.org/oil-sands/os101/water>.

"Pipeline regulator losing trust" Editorial, Winnipeg Free Press (14 May 2015), online: Winnipeg Free Press <http://www.winnipegfreepress.com/opinion/editorials/Pipeline-regulatorlosing-trust-303822661.html>.

Pynn, Larry. "Part Four: 'It Looks Like Armageddon”" Vancouver Sun (September 2012), online: Vancouver Sun

<http://www.vancouversun.com/travel/Part+Four+looks+like+Armageddon/58 14799/st ory.html>. 
Pynn, Larry. "Part One: In The Wake of a Plague” Vancouver Sun (September 2012), online: Vancouver Sun

<http://www.vancouversun.com/technology/Part+wake+plague/5800904/story.html >.

"Responsible Resource Development", online: Government of Canada $<$ http://actionplan.gc.ca/en/content/r2d-dr2>.

Other Materials

Forest Stewardship Council Regional Certification Standards for British Columbia (Toronto: Forest Stewardship Council, 2005).

Stakeholder Consultation for Forest Evaluation FSC-STD-20-006 (V3-0) (Bonn: Forest Stewardship Council International, 2009). 